\title{
DESCOMPRESSÃO PORTAL SELETIVA NA ESQUISTOSSOMOSE MANSÔNICA
}

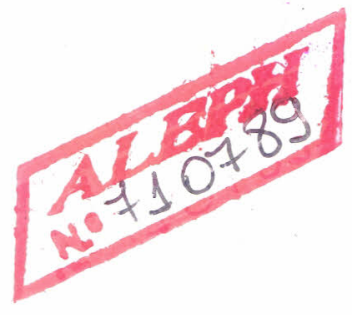

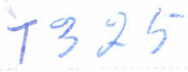

TESE APRESENTADA À FACULDADE DE MEDICINA DA UNIVERSIDADE DE SĀO PAULO PARA CONCURSO DE LIVRE DOCENNCIA DE CLINICA CIRÚRGICA 


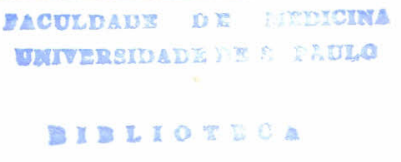

A Lina de sempre,e Virginia, Fábio,

Carola,

Eduardo,

Aninha e

Paulinha 
ReItoR: Prof. Dr. Orlando Marques de Paiva

DIRETOR: Prof. Dr. Carlos da Silva Lacaz

SECRETÁRIO: Dr. Dante Nese

\section{PROFESSORES TITULARES}

Professor Doutor Antônio Barros de Ulhoa Cintra

Professor Doutor Arrigo Antonio Raia

Professor Doutor Armando Canger Rodrigues

Professor Doutor Bussâmara Neme

Professor Doutor Carlos Alberto Salvatore

Professor Doutor Carlos da Silva Lacaz

Professor Doutor Charles Edward Corbett

Professor Doutor Eduardo Marcondes Machado

Professor Doutor Euryclides de Jesus Zerbini

Professor Doutor Fernando de Oliveira Bastos

Professor Doutor Flávio Pires de Camargo

Professor Doutor Gilberto Menezes de Goes

Professor Doutor Guilherme Rodrigues da Silva

Professor Doutor Horácio Martins Canelas

Professor Doutor Lamartine Junqueira Paiva

Professor Doutor Luiz Vénère Décourt

Professor Doutor Paulo de Almeida Toledo

Professor Doutor Paulo Braga de Magalhães

Professor Doutor Sebastião de Almeida Prado Sampaio

Professor Doutor Thales de Brito

Professor Doutor Vicente Amato Neto

PROFESSORES EMÉRITOS

Professor Doutor Alípio Corrêa Netto

Professor Doutor Antônio Carlos Pacheco e Silva

Professor Doutor Benedito Montenegro

Professor Doutor Eurico da Silva Bastos

Professor Doutor Edmundo Vasconcelos

Professor Doutor F. E. Godoy Moreira

Professor Doutor Flamínio Fávero

Professor Doutor Hilário Veiga de Carvalho

Professor Doutor João Aguiar Pupo

Professor Doutor João Alves Meira

Professor Doutor José B. Medina

Professor Doutor Pedro de A. Marcondes Machado

Professor Doutor Raphael da Nova

Professor Doutor Renato Locchi 
Esta tese foi realizada no Grupo de Fígado e Hipertensão Portal da Disciplina de Moléstias do Aparelho Digestivo e Glândulas Anexas do Departamento de Cirurgia da FMUSP (Prof. Arrigo Raia) e faz parte de um plano integrado de pesquisa programado para estudar o tratamento cirúrgico da hipertensão portal em portadores de esquistossomose hepatesplênica. 


\section{AGRADECIMENTOS}

Muitos nos auxiliaram na realização desta tese. Preferimos agradecer-lhes em conjunto, uma vez que sua colaboração inestimável nos chegou sempre na medida em que foi necessária.

Adávio de Oliveira e Silva; Alessandra Billia; Aloisio L. Carvalhaes; Alvaro F. Armbrust; Amadeo Sáez-Alquézar; Antonio Carlos Magnanelli; Antonio Carlos Marques; Antonio Luiz Vasconcelos de Macedo; Antonio Plinio Bernardini; Armando Teixeira da Silva; Banco de Sangue do Hospital das Clínicas; Carlos P. Monteiro; Dalton de Alencar Fischer Chamone; David Urbinati Netto; Douglas Linhares; Dora Cockrane; Edna Strauss; Enfermeiras do Hospital das Clínicas; Equipe de Anestesia do Hospital das Clínicas; Erkki J. Larsson; Feprnando Arashiro; Gabriel Lauro Celidônio; Geraldo Luiz Alves; Hoel Sette Jr.; Jaime Guzmán Jara; João Carlos de Sales; José Alemany; José Maria Pacheco de Souza; Luiz Caetano da Silva; Luiz Carlos da Costa Gayotto; Maria Estela Canaveira de Castilho; Maria de Lourdes Lopes da Silva Capacci; Marina Takayanagui; Monica Allegro; Noriko Ohtsuki; Read Madi; Rosa da Silva Guimarães; Sergio Mies, Simone Sultani; Tadao Mori; Therezinha Verrastro de Almeida; Walter Mittelstaedt; William Saad; Wilson Martins; Wolfgang Harry Loscher; Zilda Scalco.

Desejamos lembrar em particular:

- aqueles a quem devemos nossa formação cirúrgica e científica ou que nos receberam permitindo e amparando a continuidade do nosso trabalho:

Edmundo Vasconcelos

Arrigo A. Raia

Barbara Billing

Euríclides J. Zerbini

Peter Scheuer

Sheila Sherlock

- aqueles que mais nos estimularam para isto:

Carlos da Silva Lacaz

Ernani V. Aboim

Mário Ramos de Oliveira

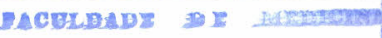

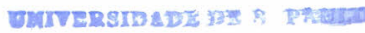

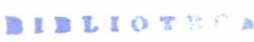

- e aqueles que tornaram possível esta forma de impressão:

Editora Guanabara-Koogan

Bloch Editores

Buri Druck A. G. (Berna, Suíça)

Sarrió Compañia Papelera de Leiza (Espanha)

Companhia Suzano de Papéis S.A. 
A mente humana que se alarga para uma nova idéia jamais retorna às dimensões primitivas. OLIVER WENDELL HOLMES 
ÍNDICE 
CAPÍTULO DOIS - ESTADO ATUAL DA QUESTÃO

1 - Tratamento cirúrgico da Hipertensão Portal em Esquistossomóticos hepatesplênicos

Método de estudo ……………………………….................................... 13

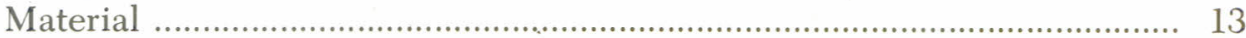

Distribuição Regional das Publicą̧ões ........................................................... 13

Classificação das Publicações : …………..................................................... 14

Tempo de seguimento ......................................................................... 14

Tipos de Tratamento Operatório ……………….................................... 15

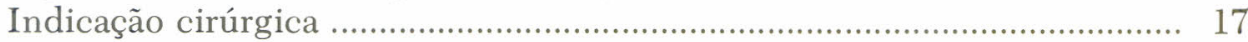

Resultados imediatos ........................................................................... 18

1 - Mortalidade operatória ................................................................. 18

2 - Efeitos na pressão portal …………………............................. 19

3 - Permeabilidade das derivaçōes venosas ...................................... 19

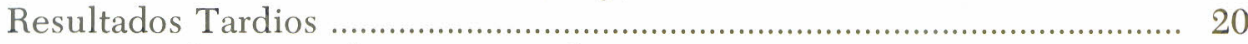

1 - Efeitos nas hemorragias digestivas ............................................. 21

2 - Efeitos neuropsíquicos …………………….............................. 22

3 - Efeitos no hiperesplenismo …………………............................ 23

4 - Efeitos na função hepática ......................................................... 24

2 - Efeitos do desvio do sangue portal para veia cava inferior (Fístula de Eck) ..................................................................... 27

Efeitos nas células hepáticas conseqüentes

à falta de sangue portal ……………………...................................... 35

Efeitos mortológicos ………………................................................. 35

1 - Resultados experimentais ………......................................... 5

2 - Observações clínicas ...................................................................... 49

Efeitos funcionais ……………............................................................ 52

1 - Resultados experimentais .................................................... 52

2 - Observações clínicas .............................................................. 57

Efeitos na capacidade de regeneração do fígado .................................... 60

Efeitos da relação entre fígado e insulina ………................................... 75

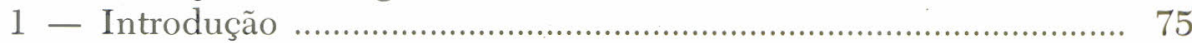

2 - Ação da insulina no metabolismo das células hepáticas ……... 75 $2 \mathrm{~A}$ - Metabolismo dos carboidratos ....................................... 75

2B - Metabolismo dos lípides ............................................. 75

2C - Metabolismo das proteínas …………………………...... 75

3 - Ação do fígado no metabolismo da insulina ............................... 76

3A - Degradação da insulina pelo fígado …………………..... 76

3B - Fixação da insulina pelo fígado ...................................... 77

3C - Alterações do metabolismo da insulina em pacientes com hepatopatia crônica .................................. 78

Efeitos da chegada direta do sangue na circulação sistêmica ………...... 79

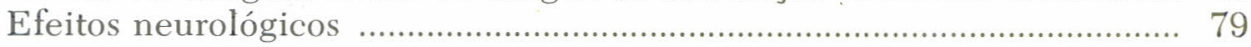

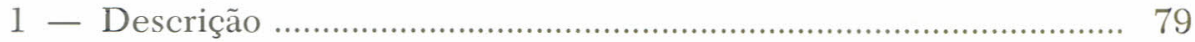

2 - Etiologia das alterações neurológicas ......................................... 80

2A - Agentes "tóxicos" responsáveis pelo quadro neurológico 
— amônía ............................................................................. 84

— outras substâncias ........................................................ 86

2B - Por que as taxas sangüíneas dos agentes

— aumento da absorção intestinal ................................... 88

- chegada direta na circulação sistêmica ...................... 88

— clareamento hepático insuficiente ............................. 88

3 - Fisiopatologia das alterações neurológicas .................................. 90

4 - Por que a EPS não ocorre em todos os animais ou pacientes submetidos a uma FE ............................................... 91 4A - Suscetibilidade cerebral ................................................. 91

4B - Efeitos protetores na circulação colateral ....................... 92

4C - Adaptação hepatocelular pela redução lenta

e progressiva do fluxo portal hepatopetal ...................... 96

Efeitos cardiocirculatórios ……………………………………………........ 96

1 - Observações em normais ............................................................. 96

2 - Observações em cirróticos .............................................................. 96

3 - Observações em esquistossomóticos hepatesplênicos ................ 98

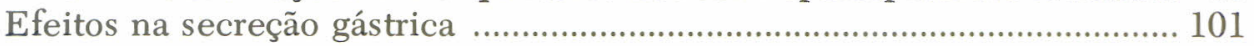

1 - Observações experimentais em modelos com fígado normal

2 - Observações experimentais em modelos com lesão

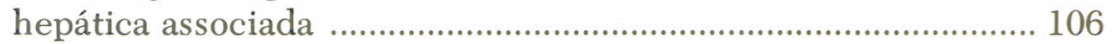

3 - Observações clínicas ..................................................................... 109

Efeitos experimentais no peso corpóreo ………………………………....... 109

3 - Sistema venoso esôfago-gástrico e recanalização após

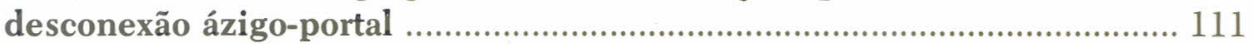

Angioarquitetura venosa normal da transição esôfago-gástrica ................. 113

1 - Via anastomótica paraesofágica ..................................................... 113

2 - Via anastomótica superficial ............................................................ 113

3 - Via anastomótica intramural ........................................................... 113

Ảterações determinadas pela hipertensão portal na

angioarquitetura da transição esôfago-gástrica ............................................. 116

1 - Rede superficial ............................................................................ 116

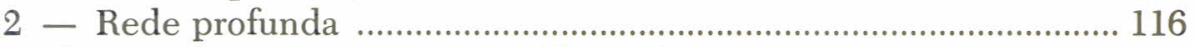

Recanalização do sistema venoso esôfago-gástrico após

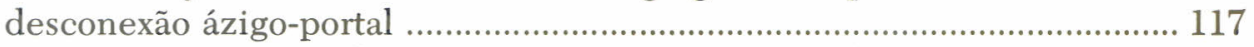

4 - Descompressão portal seletiva. Histórico e Resultados ............................. 119

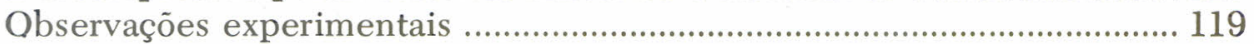

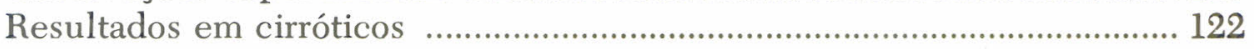

Resultados em esquistossomóticos hepatesplênicos .................................... 132

5 - Hiperesplenismo e tratamento cirúrgico da hipertensão

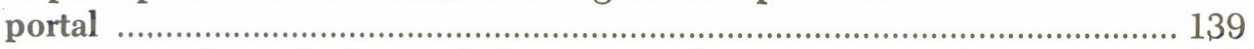

Anatomia e hemodinâmica do baço normal ……………………………...... 139

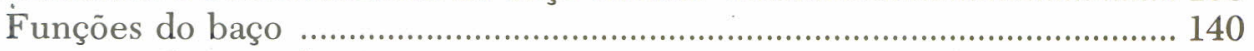

1 - Função de síntese ....................................................................... 140

2 - Função de depuração ………………………….............................. 141

3 - Função de reservatório .............................................................. 141

Etiopatogenia da esplenomegalia .......................................................... 141 
1 - sem hipertensão portal ............................................................... 141

2 - com hipertensão portal …………………...................................... 142

Conseqüências da esplenomegalia ......................................................... 143

1 - Conceito de hiperesplenismo ……….......................................... 143

2 - Patogenia do hiperesplenismo ……………..................................... 143

3 - Fisiopatologia do hiperesplenismo ............................................. 144

3A - Efeitos no volume plasmático ............................................ 145

3B - Efeitos nas hemácias ………………………………...... 145

3C - Efeitos nos leucócitos ...................................................... 146

3D - Efeitos nas plaquetas ..................................................... 146

3E - Efeitos nos fatores de coagulação …………………….... 146

$3 \mathrm{~F}$ - Efeitos no sistema endócrino ......................................... 147

Efeitos da esplenectomia no hiperesplenismo .......................................... 147

Efeitos da descompressão portal no hiperesplenismo ............................... 148

1 - Anastomose Porto-Cava (APC) ..................................................... 148

2 - Descompressão Portal Seletiva (DPS) .......................................... 150

Efeitos da irradiação esplênica no hiperesplenismo ................................... 151

6 - Substitutos vasculares com especial referência ao

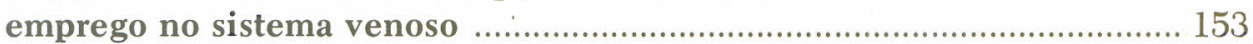

Evolução histórica dos substitutos vasculares .......................................... 155

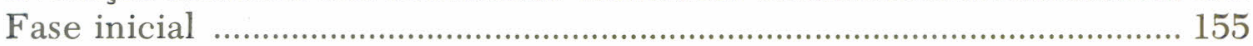

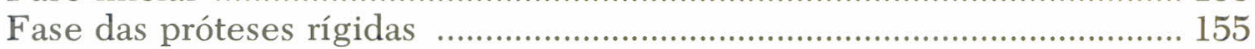

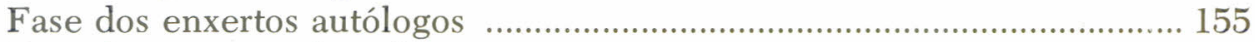

Fase dos enxertos homólogos ……....................................................... 156

Fase das próteses sintéticas …………............................................. 156

Fase dos enxertos heterólogos tratados ..................................................... 156

Substitutos vasculares mais recentes ………………................................ 157

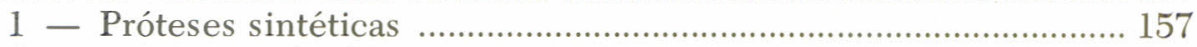

2 - Substitutos biológicos não vasculares ....................................... 159

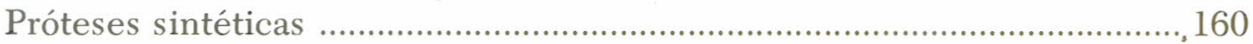

1 - Materiais sintéticos do tipo "termosetting”" ................................. 161

3 - Materiais sintéticos do tipo "termoplastic" ................................... 161

Cicatrização das próteses sintéticas ........................................................ 162

1 - Características das próteses sintéticas ......................................... 164

1A — Tipo de malha ............................................................ 164

1B - Porosidade ................................................................ 165

1C - Comprimento e diâmetro .................................................. 165

ID - Consistência da parede .................................................. 166

1E - Carga elétrica ................................................................ 166

2 - Pormenores técnicos da substituição …………............................. 166

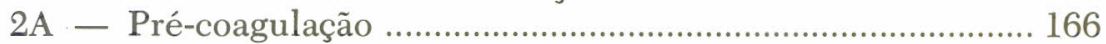

2B - Tipos de sutura .......................................................... 167

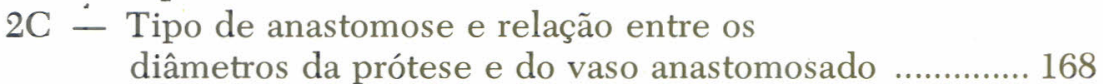

3 - Características do sistema vascular hospedeiro ............................ 169

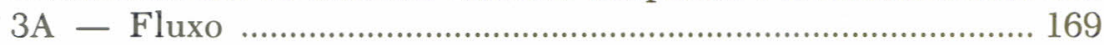

3B - Pressão ......................................................................... 170

Resultados no sistema arterial ................................................................ 171

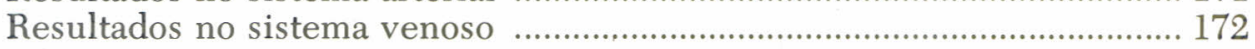


Resultados no sistema cava ..................................................................... 173

1 - Resultados experimentais (fig. 230) ................................................ 173

2 - Resultados clínicos (fig. 231) ......................................................... 176

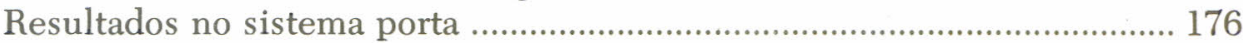

1 - Resultados experimentais (fig. 230) …………............................ 176

2 - Resultados clínicos (fig. 231) ....................................................... 180

CAPÍTULO TRÊS - CASUÍSTICA. CARACTERIZAÇÃO DOS PACIENTES. PLANO DE PESQUISA. MÉTODO.

INSTRUMENTAL E EQUIPAMENTOS …........................ 191

1 - Casuística. Caracterização dos pacientes. Plano de

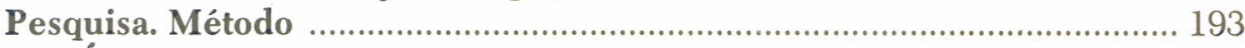

Caracterização dos pacientes …………………....................................... 195

1 - Diagnóstico da esquistossomose mansônica ................................. 195

2 - Avaliação pré-operatória suplementar .......................................... 195

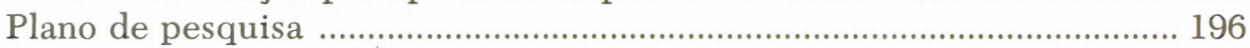

1 - Estudo hemodinâmico-angiográfico …………………………........ 196

2 - Estudo da função hepática ............................................................ 197

3 - Estudo das varizes esôfago-gástricas ……………………….......... 197

4 - Estudo do hiperesplenismo ......................................................... 199

5 - Tratamento operatório ...................................................................... 201

5A - Preparo do doente ................................................................. 201

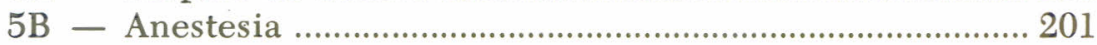

5C - Controles intra-operatórios …………………..................... 202

5D - Técnica cirúrgica ………………………….................... 202

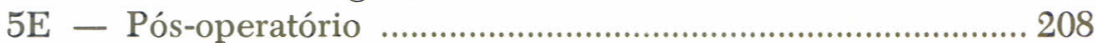

$5 \mathrm{~F}$ - Estudo das complicações pós-operatórias ......................... 208

Apresentação dos resultados ...................................................................... 211

2 - Instrumental e Equipamentos .......................................................................... 212

CAPÍTULO QUATRO — RESULTADOS _...................................................... 215

Resultados intra-operatórios ...................................................................... 219

Inspeção macroscópica ……………………..................................... 219

Aspectos técnicos das anastomoses .................................................... 219

Efeitos imediatos da DPS na pressão portal ……………………….... 220

Complicações operatórias imediatas ……………...................................... 221

Evolução das anastomoses ……………………......................................... 223

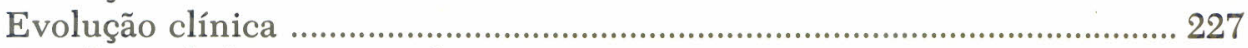

Recidivas da hemorragia digestiva ........................................................ 227

Comportamento neuropsíquico ……………............................................... 227

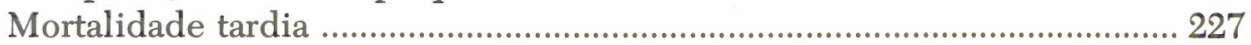

Efeitos da Descompressão Portal Seletiva (DPS) ………………………..... 231

Hemodinâmicos angiográficos .................................................................... 231

1 - Diâmetro da artéria hepática comum ……………………………... 231

2 - Diâmetro da artéria esplênica .......................................................... 232

Relação entre o diâmetro da artéria hepática
comum e o diâmetro da artéria esplênica ...................................... 233

4 - Aspecto arterial intra-hepático .................................................... 234

5 - Diâmetro da veia porta .................................................................... 240 
6 - Diâmetro da veia esplênica

7 - Relação entre o diâmetro da veia porta e o diâmetro da veia esplênica ........................................................... 242

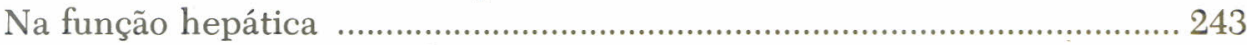

1 - Proteínas totais do soro ................................................................. 243

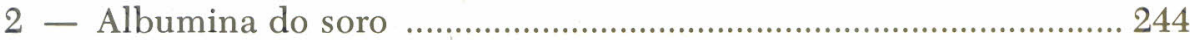

3 - Globulinas do soro ..................................................................... 245

4 - Alamina aminotransferase do soro ……………........................... 246

5 - Aspartato aminotransferase do soro ............................................. 248

Nas varizes esôfago-gástricas ………………………................................. 250

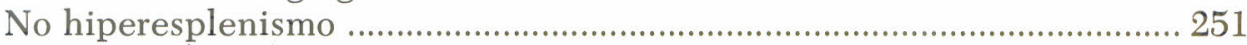

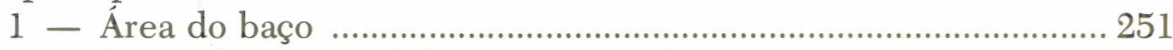

2 - Hemoglobina total do sangue periférico .................................... 252

3 - Eritrócitos do sangue periférico …………………....................... 253

4 - Leucócitos do sangue periférico …………………………........ 254

5 - Plaquetas do sangue periférico .................................................. 255

6 - Reticulócitos do sangue periférico …………………………..... 256

7 - Hiaptoglobinas do soro ………………………............................... 257

8 - Bilirrubina direta do soro ………………................................... 258

9 - Bilirrubina indireta do soro ........................................................ 260

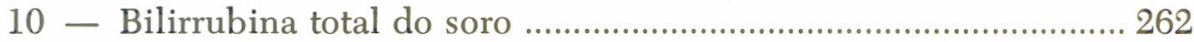

11 - Tempo de protrombina do plasma …………............................ 264

12 - Fibrinogênio do plasma ……………………….......................... 265

13 - Tempo de lise da euglobulina do plasma ................................... 266

14 - Monômeros solúveis de fibrina do plasma …………………..... 267

15 - Produtos de degradação do fibrinogênio do soro ........................ 268

16 - Fator V do plasma ........................................................................ 269

17 - Fator XIII do plasma ................................................................... 270

18 - Tempo de trombina do plasma .................................................... 271

CAPÍTULO CINCO — COMENTÁRIOS …………............................................... 273

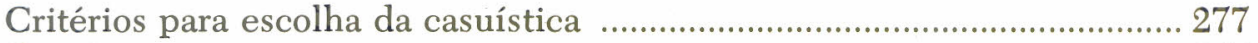

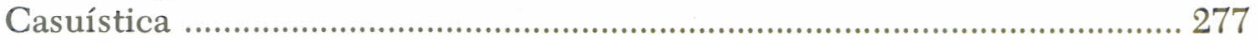

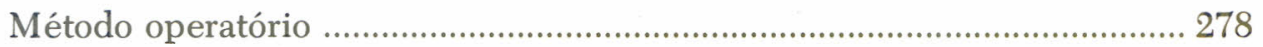

Período de estudo .................................................................................. 280

Escolha dos parâmetros ………………………………………………….... 280

Tratamento estatístico e apresentação dos resultados .................................. 281

Tratamento operatório ………………………............................................ 281

Complicações pós-operatórias imediatas ………….................................... 283

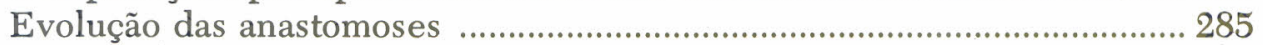

Efeitos da Descompressão Portal Seletiva ………………………………... 288

Descompressão Portal .......................................................................... 288

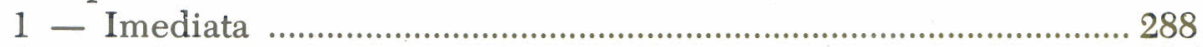

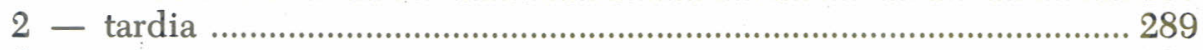

Evolução clínica .......................................................................................... 289

1 - Recidiva da hemorragia .............................................................. 290

1A - Efeitos nas varizes de esôfago .........................................290

1B - Controle da hemorragia .................................................... 292

2 - Comportamento neuropsíquico ...................................................... 294 
$2 \mathrm{~A}$ - Comparação dos nossos resultados com os referidos na literatura .............................................. 296

2B - Importância da falta de desvio do sangue mesentérico para a circulação sistêmica ......................... 298

2C - Importância da interrupção da circulaçãơ colateral gastresofágica

2D - Importância da manutenção do fluxo sangüíneo do território portal direito em direção ao fígado

A - Fluxo portal após DPS ........................................... 301

B - Efeitos na morfologia do fígado .......................... 305

C - Efeitos na função hepática ................................ 312

3 - Hiperesplenismo ..................................................................... 313

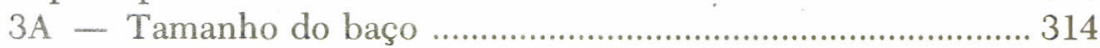

3B - Seqüestro esplênico ................................................. 315

$3 \mathrm{C}$ - Bilirrubinemia ........................................................ 316

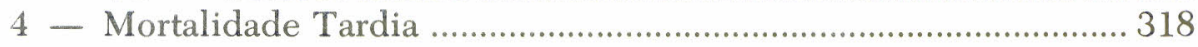

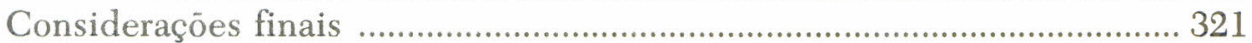

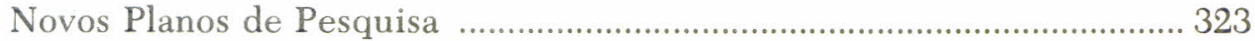

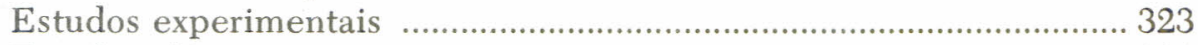

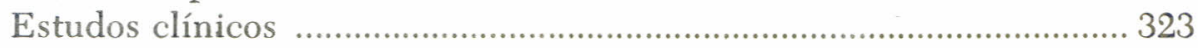

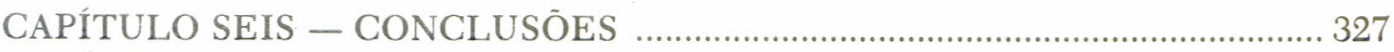

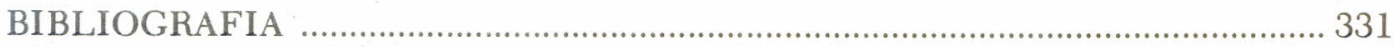

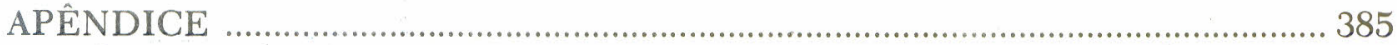




\section{INTRODUCÃO}


A esquistossomose mansônica representa grave problema médico social para o Brasil. Estima-se em cerca de dez milhões o número de infestados, dos quais $10 \%$ com a forma avançada da moléstia 595 B

$\mathrm{O}$ problema adquire particular dramaticidade com a hemorragia digestiva nos portadores da forma hepatesplênica que quase sempre não apresentam insuficiência hepática ou sintomas graves de outro tipo. Assim, a interrupção definitiva da hemorragia, se associada à cura da parasitose, recupera estes pacientes geralmente acometidos na idade de maior produtividade e participação comunitária.

Compreende-se dessa maneira a atenção conferida ao tratamento cirúrgico da hipertensão portal na esquistossomose, assunto de 22 teses só na Faculdade de Medicina da USP.

Apesar disso, não foram obtidas conclusões definitivas. Provavelmente, pelo caráter migratório da população parasitada, menos de $5 \%$ dos 4.516 casos operados, publicados no Brasil ou no exterior, foram estudados durante cinco anos e com percentagem de retorno satisfatória. Permanecem, assim, sem respostas perguntas fundamentais como: tivas?

- Qual a eficácia dos métodos empregados para controlar as hemorragias diges-

- Qual a incidência de efeitos colaterais indesejáveis?

- Os benefícios obtidos justificam o risco das complicações?

- As operações aumentam a sobrevida dos pacientes?

Estes esclarecimentos só serão fornecidos por meio de investigações clínicas executadas com metodologia mais apropriada. Como ocorreu para os cirróticos, são necessários estudos prospectivos com escolha aleatória da conduta cirúrgica, comparação com grupo controle e seguimento suficiente.

Entretanto, a programação e a execução de pesquisas desse tipo dependem de uma série de pré-requisitos. Antes de mais nada, da conscientizaçąo da dúvida sobre qual é o melhor método operatório e do reconhecimento de que os controles poderiam evoluir melhor que os submetidos a tratamento cirúrgico. Uma vez atingida esta fase, escolhem-se quais as condutas operatórias que serão comparadas com o grupo controle. A seleção, porém, não é fácil e inclui aspectos éticos muito delicados, uma vez que a inclusão de um determinado tipo de cirurgia só se justifica desde que os resultados previamente obtidos sejam condizentes com a hipótese de que possa vir a representar a melhor conduta. Somente assim pode-se aceitar a decisão por sorteio.

As técnicas atualmente mais empregadas para o tratamento cirúrgico das varizes sangrantes em Esquistossomóticos Hepatesplênicos (EHE) são a esplenectomia simples associada ou não à desconexão ázigo-portal e à anastomose espleno-renal. A insatisfação com estes métodos decorre da freqüência de recidivas hemorrágicas dos dois primeiros e da encefalopatia porto-sistêmica do último. Estes inconvenientes foram atribuídos, respectivamente, à falta de descompressão suficiente do território gastresofágico e ao desvio do sangue portal para a circulação sistêmica.

Independentemente e quase ao mesmo tempo, em 1967, Dean Warren e Edison Teixeira idealizaram uma solução técnica para evitar estes inconvenientes propondo a Descompressão Portal Seletiva (DPS). Demonstraram que a anastomose do coto distal da veia esplênica na veia renal esquerda descomprime as varizes esofagogástricas sem desviar o fluxo mesentérico que persiste em direção ao fígado.

Em 1971, já conhecendo os resultados favoráveis em cirróticos, indicamos o novo método em EHE, analisando os efeitos imediatos que constituíram assunto de teses apresentadas por componentes do grupo a que pertencemos ${ }^{119-800}$ 
Agora, animados pelos resultados precc es, resolvemos estudar o comportamento tardio, conferindo particular atenção aos efeitos fisiopatológicos que o determinam. Esta tese apresenta 21 EHE submetidos à DPS e estudados durante um período de doze a 57 meses (seguimento médio de 33 meses). Pretende fornecer elementos para decidir se esse método operatório deve ou não ser incluído em estudos prospectivos controlados futuros. 
Capitulo Dois

\section{ESTADO ATUAL DA QUESTÃO}


Salomon saith: "There is no new thing upon the earth. All knowledge is but remembrance, so all novelty is but oblivion". 


\section{1 \\ TRATAMENTO CIRÚRGICO DA HIPERTENSÃO PORTAL EM ESQUISTOSSOMÓTICOS HEPATESPLÊNICOS ("OPERACQ̄ôES CLÁSSICAS")}

O tratamento cirúrgico da hipertensão portal causada pela Esquistossomose Mansônica (EM) despertou grande interesse nos centros especializados do país e do exterior. Publicaram-se os resultados obtidos em aproximadamente 4.500 casos operados.

Todavia, os aspectos fundamentais são discutidos apenas em base de observações isoladas ou de impressões adquiridas na experiência pessoal dos autores. A falta de metodologia apropriada explica o ponto de vista de Ronald A. Malt expresso, recentemente, no "New England Journal of Medicine"467. Comentou que, em relação aos Esquistossomóticos Hepatesplênicos (EHE), apesar do grande número de pacientes operados, é impossível avaliação adequada, uma vez que as publicações sobre os resultados cirúrgicos "tend to be anedoctal".

Situação semelhante foi evidenciada pelo "Inter Hospital Boston Liver Group", em 1966, para o tratamento cirúrgico da hipertensão portal em cirróticos. Grace e col. ${ }^{311}$ avaliaram 154 publicaçōes sobre o assunto, classificando um único estudo clínico como bem estruturado sob o aspecto de metodologia científica. Chegaram a esta conclusão desalentadora dividindo os trabalhos da seguinte maneira:

- cada uma das 154 publicações foi estudada, independentemente, por Norman Grace e Thomas Chalmers. Os trabalhos cuja classificação foi divergente foram submetidos a um terceiro analista para desempate obtido sem conhecimento da classificação prévia discordante.

As publicações foram classificadas em:

- estudos bem controlados: os pacientes devem ser incluídos ainda sem conduta terapêutica definida. Esta é escolhida por sorteio entre uma ou mais alternativas cirúrgicas e uma não cirúrgica. Os pacientes sorteados para esta última constituem o grupo controle;

- estudos precariamente controlados: a escolha da conduta é orientada por julgamento clínico. Os resultados são comparados com um grupo controle escolhido retrospectivamente ou com grupos de outros centros de investigação clínica;

— estudos não controlados: os resultados não são comparados com os de um grupo controle.

A partir dessa análise básica iniciaram-se, em vários países, investigações clínicas rigorosamente planejadas e executadas. Nos últimos dez anos, estabeleceram-se assim pontos básicos para a solução do problema. Dentre eles destaca-se a contraindicação formal da Anastomose Porto-Cava (APC) em cirróticos com varizes de esô- 
fago não sangrantes (indicação profilática). Além disso, as informações conseguidas com estudos prospectivos controlados diminuíram o entusiasmo existente na época quanto às derivações porto-sistêmicas globais. Pelo contrário, criaram um ambiente de insatisfação e dúvida quanto aos reais benefícios determinados por esse tipo de tratamento operatório. Tal percepção levou muitos cirurgiões de volta à biblioteca ë ao laboratório de cirurgia experimental. Foram assim reavaliados conhecimentos anteriores e obtidas informações fisiopatológicas inéditas. 'Este enfoque determinou a aplicação de novos métodos terapêuticos com resultados nitidamente superiores. Dentre eles salienta-se a Descompressão Portal Seletiva (DPS), pelas suas bases fisiopatológicas e pelos excelentes resultados alcançados em cirróticos.

Esta seqüência de eventos estimulou um levantamento bibliográfico semelhante para oś EHE. 
. MÉTODO DE ESTUDO

A pesquisa bibliográfica compreende 0 período de 1908 a 1976. As fontẻs disponíveis incluíram:

1 - Bibliografia Brasileira sobre EM, no período de 1908. a 1970, editada em 1970 por Eurides Pires de Santana e Gilberto Rebouças, em Salvador-Bahia;

2 - Bibliografia Brasileira de Medicina (1969-1972);

3 - Index Medicus (1960 a 1975);

4 - Excerpta Medica Surgery (19601976);

5 - Excerpta Medica Internal Medicine (1960-1976);

6 - I Simpósio sobre Esquistossomose, editado por Aluízio Prata e Ernani Aboim, em 1957, Salvador-Bahia ${ }^{596}$;

7 - II Simpósio sobre Esquistossomose, editado por Aluízio Prata e Ernani Aboim, em 1970, Salvador-Bahia ${ }^{597}$;

8 - Fichário de teses da biblioteca da FMUSP.

Numa primeira etapa foram excluídos os trabalhos:

- que não mostravam casuística própria;

- cujo tipo de apresentação não permitiu identificar os casos com EM dentre os demais;

- em que não foi possível definir os resultados de cada um dos tipos de tratamento cirúrgico indicados, sucessivamente, no mesmo paciente;

- com resultados apresentados em publicações anteriores já incluídas no estudo. É possível, porém, que em alguns casos a falta de esclarecimentos tenha permitido repetições inadvertidas;

- referentes à DPS, uma vez que foram analisados à parte.

MATERIAL

A pesquisa bibliográfica forneceu 130 publicações (citadas na pág. 25)

Destas, 59 foram descartadas, logo de início, conforme o critério estabelecido.

Dentre as 71 incluídas no estudo, cinqüenta referiam-se apenas a EHE. As 21 restantes diziam respeito a pacientes com várias moléstias. O diagnóstico foi apenas citado ou obtido através de um ou mais dos métodos propedêuticos constantes na tabela 1.

TABELA 1

\section{DIAGNÓSTICO DA ESQUISTOSSOMOSE MANSONNICA}

\begin{tabular}{|c|c|}
\hline $\begin{array}{c}\text { MÉTODO } \\
\text { PROPEDEUTICO. }\end{array}$ & $\begin{array}{c}\text { NÜMERO } \\
\text { DE PUBLICAÇÕES }\end{array}$ \\
\hline DADOS CLINICOS & 17 \\
\hline EXAME DE FEZES & 27 \\
\hline BIOPSIA RETAL & 17 \\
\hline INTRADERMORREAÇÃO & 11 \\
\hline BIOPSIA HEPÁTICA & 33 \\
\hline PADRÃO ANGIOGRÁFICO & 2 \\
\hline NĀO MENCIONADO & 27 \\
\hline
\end{tabular}

Consideraram-se apenas as publicações com cinco ou mais casos em cada grupo de estudo para classificação segundo critério de Grace e col. ${ }^{311}$ bem como para a análise dó tempo de seguimento, avaliação da mortalidade operatória e comparação dos resultados imediatos e tardios. Para o estudo dos demais aspectos, aproveitaram-se todas as 71 publicações incluídas.

O material não foi submetido a tratamento estatístico pela falta de uniformidade na metodologia empregada pelos diferentes autores.

\section{DISTRIBUIÇÄO REGIONAL DAS PUBLICAÇÕES (FIGS. 1,2)}

$\mathrm{Na}$ figura 1 relacionam-se os países com o número de casos publicados. $\mathrm{Na}$ figura 2 relacionam-se os Estados do Brasil, com o número de casos publicados. Compilaram-se no total 4.516 casos 
dos quais 1.432 operados no exterior e 3.084 no Brasil. Na Bahia, em São Paulo e em Pernambuco operaram-se $85 \%$ dos casos nacionais. Estes dados mostram a importância e o interesse dos cirurgiões brasileiros para o problema e sugerem o caráter migratório da população parasitada.

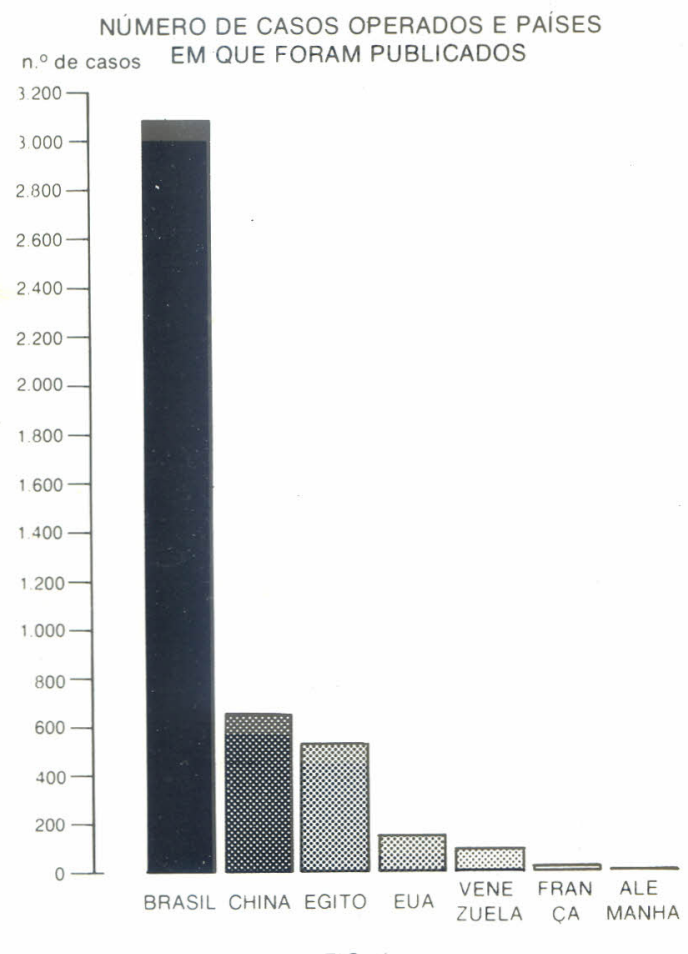

FIG. 1

NÚMERO DE CASOS E ESTADOS DO BRASIL

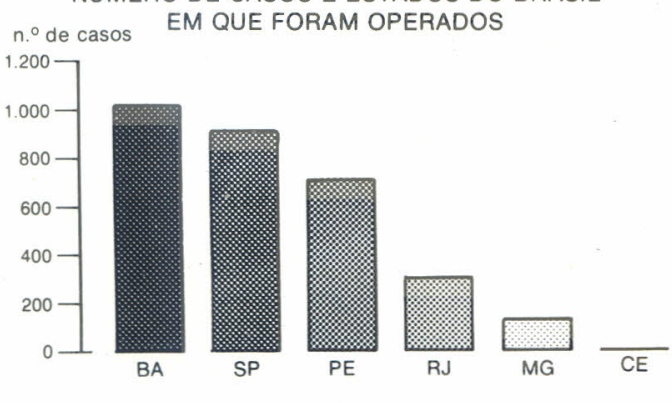

FIG. 2
CLASSIFICAÇÃO

DAS PUBLICAÇÕES (TABELA 2)

Segundo o critério de Grace e col. ${ }^{311}$ não foram encontrados estudos prospectivos ou retrospectivos bem controlados. Predominam nitidamente os retrospectivos sem grupo controle, que representam cerca de $90 \%$ das investigações. O único estudo prospectivo que incluiu grupo controle, ainda que precário, examinou resultados da APC, atualmente contraindicada.

A publicação que apresentou estudo prospectivo sem grupo controle diz respeito a apenas dois grupos de estudo, com seguimento de um ano, retorno de $92 \%$ dos operados. e não cita qualquer observação após este período.

TABELA 2

\section{CLASSIFICACÃO DAS PUBLICACÕES CONFORME O CRITÉRIO DE GRACE E COL.311}

(COM 5 OU MAIS CASOS EM CADA GRUPO)

\begin{tabular}{l|c|c|c|c}
\hline \hline & \multicolumn{3}{|c|}{ CONTROLE } & \\
\cline { 2 - 4 } & BOM & PRECARIO & $\begin{array}{c}\text { AUSEN- } \\
\text { TE }\end{array}$ & TOTAL \\
\hline \begin{tabular}{l|c|c|c} 
ESTUDO \\
PROSPECTIVO
\end{tabular} & - & 1 & 1 & 2 \\
\hline ESTUDO & - & 3 & 50 & 53 \\
\hline RETROSPECTIVO & - & 4 & 51 & 55 \\
\hline TOTAL & - & 4 & & \\
\hline
\end{tabular}

TEMPO DE SEGUIMENTO

(FIGS. 3, 4)

Em cerca de $75 \%$ dos pacientes pesquisados (cinco ou mais casos em cada grupo de estudo) não foi possível conseguir informações sobre resultados precoces ou tardios. O tempo de seguimento não foi referido ou foi apresentado sem especificar sua duração em cada caso.

O seguimento dos outros $25 \%$ (946 casos), mencionados em quinze publica- 


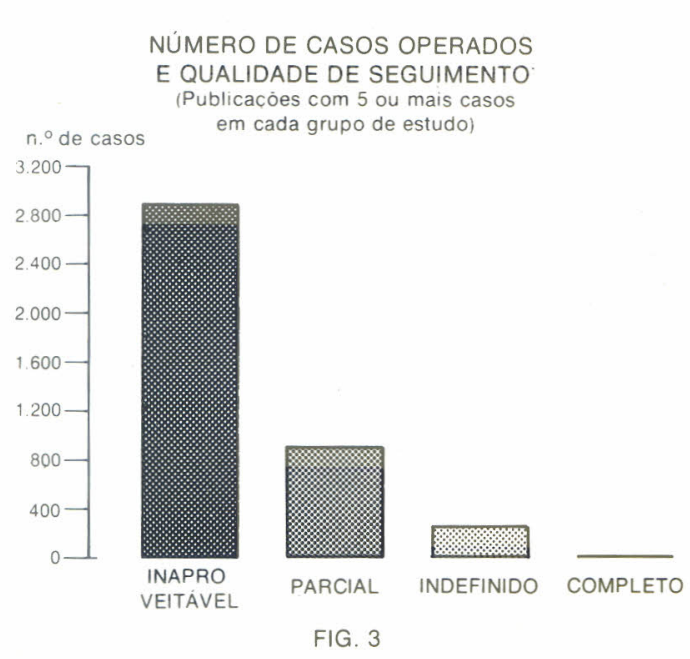

ções também não levou a conclusões definitivas apesar de bem apresentado uma vez que a percentagem de retorno foi muito pequena. Somente duas publicações 319846 referem 38 casos, incluídos em três grupos de estudo, com alta percentagem de retorno mas apenas por um ano. Nos 908 casos restantes, a volta para controle foi determinada pela iniciativa dos pacientes.

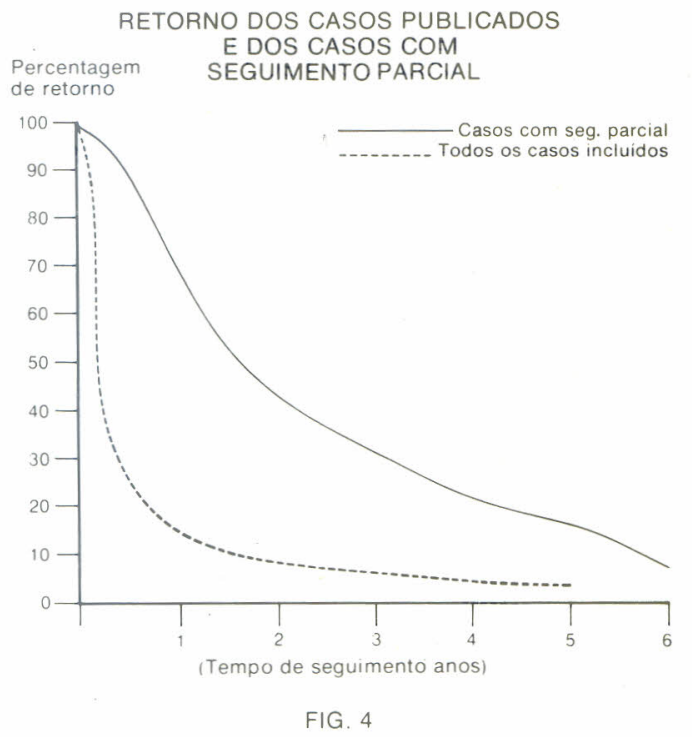

Pouco mais de $68 \%$ retornaram após um ano, $42 \%$ após dois anos, $30 \%$ após três anos e apenas $16 \%$ no fim de cinco anos. Desta forma, dos 4.516 EHE publicados, $13,9 \%$ foram seguidos durante um ano, $8,4 \%$ em dois anos, $6,0 \%$ em três anos, $4,4 \%$ em quatro anos e somente $3,2 \%$ durante cinco anos.

\section{TIPOS DE TRATAMENTO OPERATÓRIO (FIGS. 10, 11)}

Predominam a Esplenectomia Simples (ES) (Fig. 5), a Desconexão Ázigo-Portal associada à Esplenectomia (DAPE) (Fig. 6) e Anastomose Espleno-Renal (AER) (Fig. 7), perfazendo um total de $81,6 \%$. A APC (Fig. 8) apareceu com freqüência aproximadamente igual à metade da apresentada pela AER. Chama a atenção a preferência dada pelos autores chineses à esplenectomia associada à omentopexia (ESO) (Fig. 9), realizada em 240 pacientes. Além disso, é surpreendente verificar o número de técnicas diferentes empregadas para o tratamento de uma única moléstia. Não são muitas as afecções cirúrgicas para cujo tratamento tenham sido realizadas 29 técnicas distintas.

A divisão dos casos operados conforme o tratamento e as décadas em que foram publicados evidenciam:

- com exceção de doze casos submetidos a ES, publicados anteriormente, a divulgação dos resultados em EHE teve início na década de 1950;

- verificou-se assim um atraso em relação aos cirróticos cujos resultados já tinham sido publicados, em outros países, durante a década anterior. Deve-se salientar, porém, que a primeira APC em EHE foi realizada por Edmundo Vasconcelos já em fevereiro de $1946{ }^{828}$;

- a grande maioria dos casos foi divulgada na década iniciada' em 1960;

- de 1970 para cá nota-se nítido desinteresse para o assunto. Nos últimos 

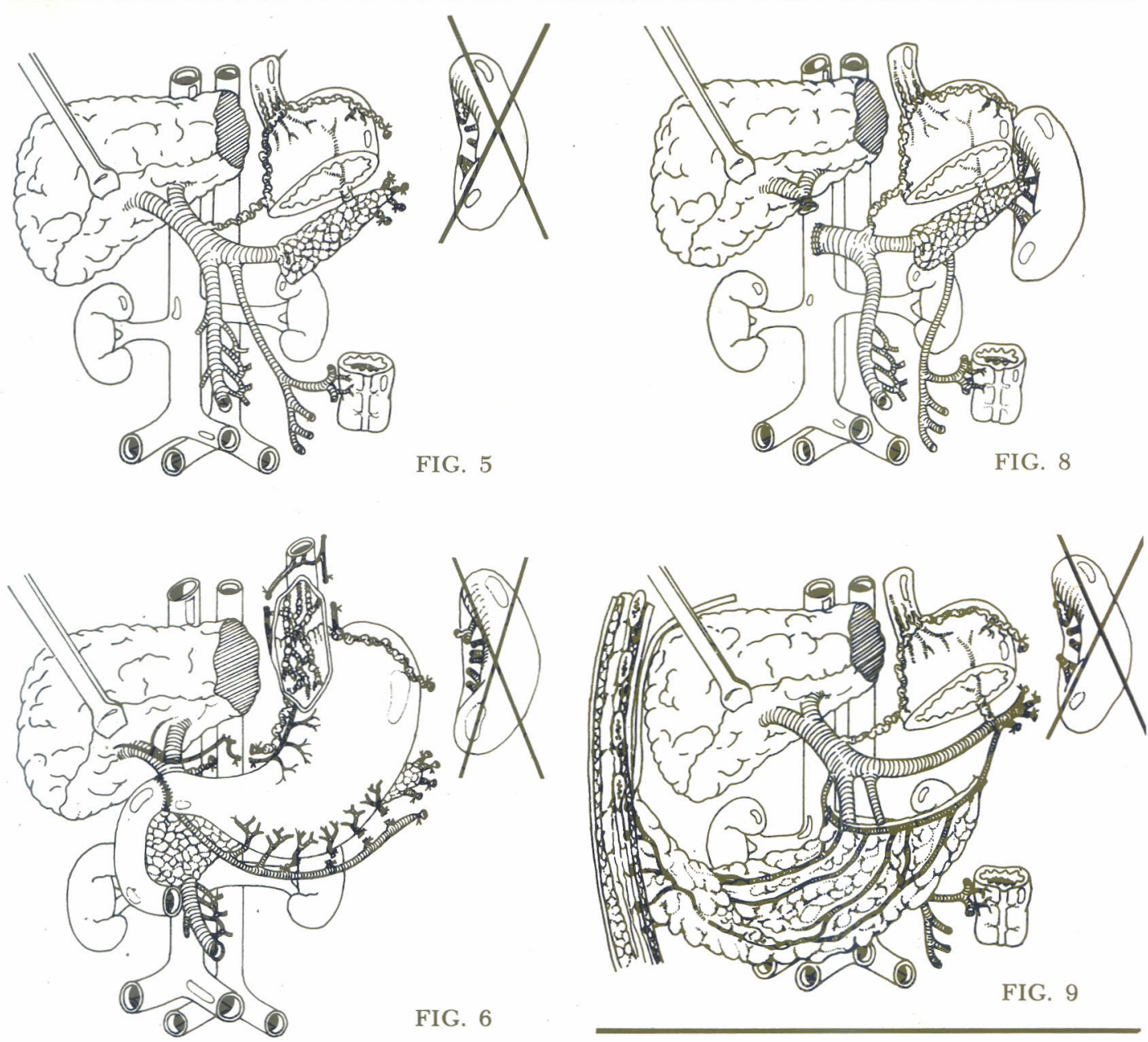

FIG. 9

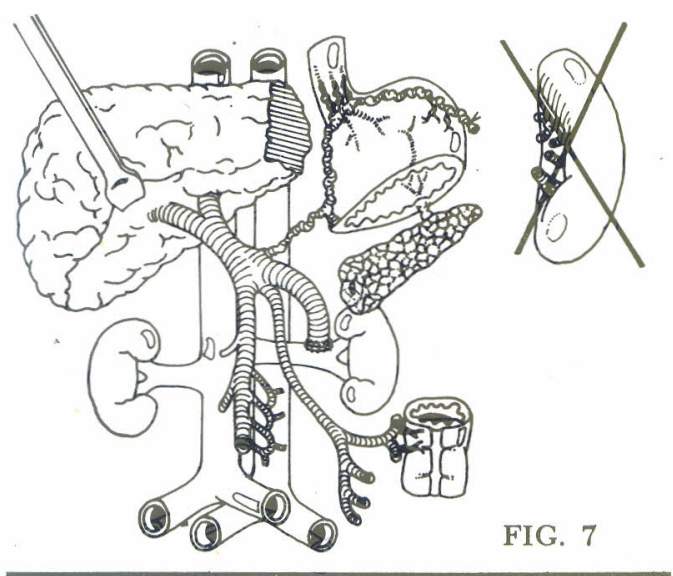

cinco anos foram publicados apenas 254 casos correspondendo a pouco mais de $7 \%$ dos operados na década anterior;

- apesar de ter sido empregada desde o início, a ES continua merecendo a preferência de um grande número de autores;

- a DAPE teve grande aceitação na década iniciada em 1960. Todavia, não foram encontradas referências, depois de 1970 (dentro do critério estabelecido);

- em relação às derivações APC e AER observa-se que durante a década de 1950 publicaram-se casuísticas praticamente iguais. Já, a partir de 1960, a APC foi sendo progressivamente menos em- 


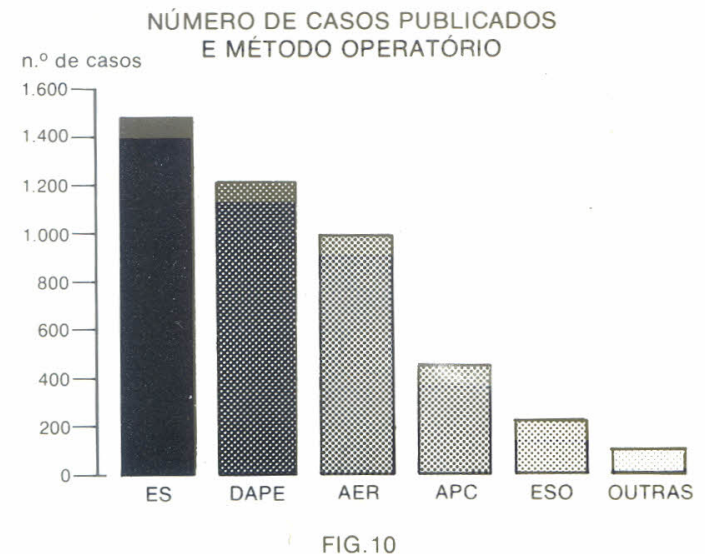

NÚMERO DE CASOS OPERADOS, DÉCADA DA PUBLICAÇĀO

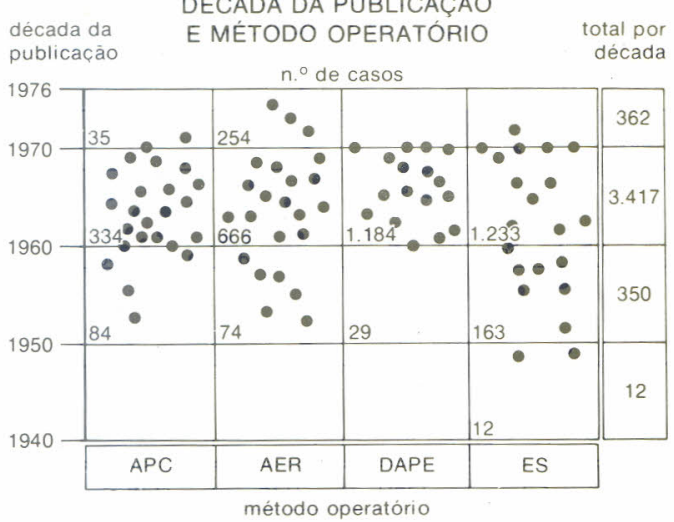

FIG. 11

pregada do que a $\mathrm{AER}$, que representa a única técnica com resultados divulgados até recentemente. As últimas APC foram publicadas em 1970 por um autor que termina seus comentários contraindicando-a em EHE.

INDICAÇÃO CIRÚRGICA (FIGS. 12, 13)

Em mais da metade dos casos publicados (53\%) faltam referências esclare- cendo se a cirurgia foi realizada antes de sangramento digestivo (indicação profilática), pelo menos trinta dias depois deste fenômeno (indicação terapêutica), ou na vigência de um episódio hemorrágico (indicação de urgência).

O termo "profilática”, usado para definir a indicação da cirurgia antes de sangramento digestivo, não é muito adequado. De fato, nos casos correspondentes, a operação foi, geralmente, indicada para tratamento de hiperesplenismo. Assim, sob alguns aspectos, foi também terapêutica.

Nos 2.108 casos em que a indicação é definida, predomina a terapêutica representando $62,7 \%$ dos casos. A de urgência foi mais rara, citada apenas em 6,6\% dos operados.

A maioria das derivações venosas (APC e AER) foi efetuada com indicação terapêutica e apenas excepcionalmente como tratamento de urgência $(0,5 \%)$.

- pelo contrário, a DAPE foi a mais indicada na urgência. Cerca de $34 \%$ dos casos deste grupo foram operados nestas condições;

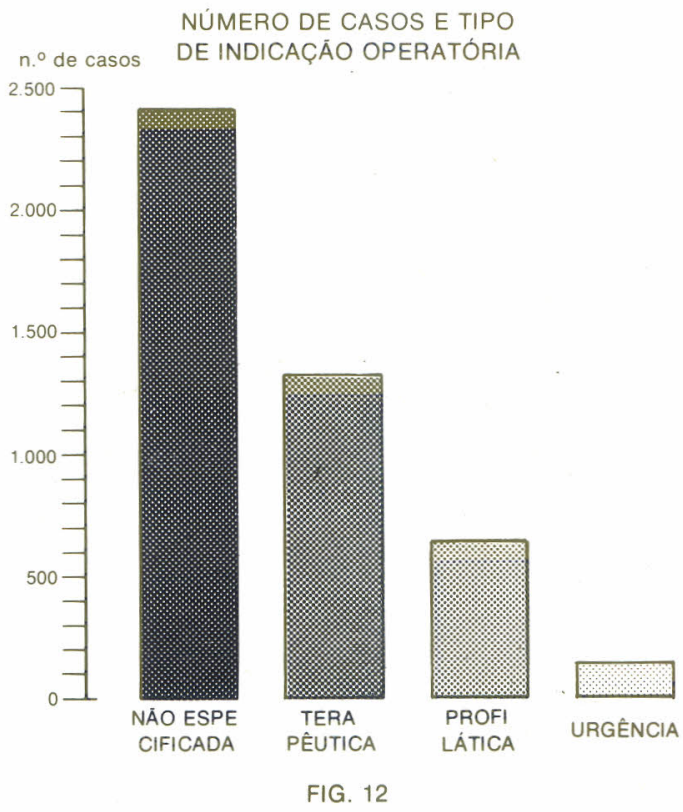




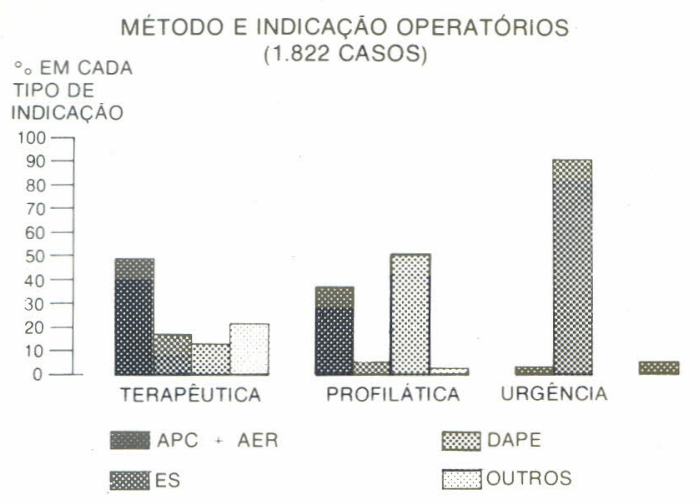

FIG. 13

- faltam referências sobre ES em condições de urgência: Sua maior aplicação ocorreu na forma profilática $(68,2 \%$ das vezes).

Em qualquer grupo, o pequeno núnero de casos publicados com indicação de urgência pode ser atribuído à natural hesitação em referir os maus resultados geralmente obtidos nestas circunstâncias.

RESULTADOS IMEDIATOS

MORTALIDADE OPERATÓRIA (FIG. 14)

Obedecendo o critério estabelecido, aproveitaram-se os resultados de 83 casuísticas referentes aos grupos APC, AER, ES e DAPE. Destas, dezenove (23\%) não citam informações sobre mortalidade operatória e dez (12\%) afirmam ausência de óbitos imediatos. É lícito supor que estas últimas sejam constituídas por casos escolhidos retrospectivamente, falseando a média geral de ocorrência do evento no grupo correspondente.

Resolvemos estudar a mortalidade da indicação de urgência apenas no grupo DAPE, visto que apenas cinco casos foram submetidos a uma derivação venosa e nenhum foi esplenectomizado na vigência de sangramento.
De uma maneira geral, a incidência da mortalidade foi relativamente baixa em todos os grupos com indicação terapêutica e profilática. Entretanto, chamam a atenção os valores observados no grupo APC. Além de apresentar a incidência mais alta, verifica-se que para o seu cálculo foram incluídas seis casuísticas que não mencionam óbitos imediatos. Excluindo-se estes valores, a mortalidade calculada teria sido ainda maior. Esta observação pode ser relacionada com os efeitos imediatos da trombose da anastomose. Refere-se íleo prolongado, trombose de segmentos extensos do sistema porta e hemorragia gastresofágica fatal.

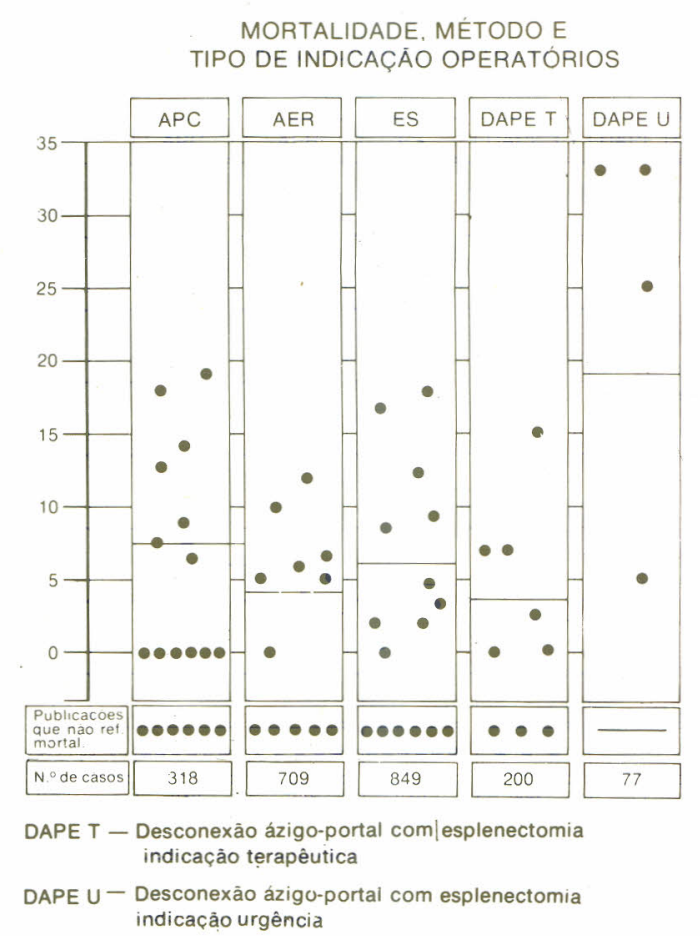

FIG. 14

Para o grupo ES, wia justo prever mortalidade operator mais baixa em conseqüência de ma1or facilidade técnica que, entretanto, não ocorreu. É lícito especular que tal comportamento 
seja conseqüente a dois fatores: o predomínio neste grupo de pacientes com esplenomegalia e hiperesplenismo acentuados, como sugerido pela freqüência da indicação profilática. Além disso, por ser operação tecnicamente mais simples, pode ter sido realizada por equipes menos experientes.

A mortalidade do grupo DAPE com indicação de urgência foi de 19,5\%, valor nitidamente mais alto que o mencionado no mesmo grupo com indicação terapêutica $(3,7 \%)$. A diferença evidencia a gravidade das conseqüências do sangramento digestivo também para os EHE, argumento de há muito citado para os cirróticos.

\section{EFEITOS NA PRESSÃO PORTAL (FIG. 15)}

Em 629 casos foram efetuadas medidas intra-operatórias da pressão no sistema porta. A média ponderal da pressão inicial foi de $344 \mathrm{~mm}_{2} \mathrm{H}_{2} \mathrm{O}$. O tamanho da amostra permitiria aceitar este resultado como representativo para os EHE. Entretanto, deve-se considerar que faltam informações sobre o estágio da moléstia nos pacientes analisados. Além destas, há carência de mais detalhes sobre a técnica de medida, como por exemplo a marcação do nível do zero na escala empregada.

O tipo de amostragem e sua forma de apresentação não permitiram tratamento estatístico. Apesar disso, podem-se comentar alguns aspectos dos efeitos pressóricos nos diferentes grupos. A pressão portal final mais alta foi observada no grupo DAPE é a mais baixa no grupo AER. Considerando de um lado que os dois métodos incluem esplenectomia e de outro que a iıgadura das varizes parece não deterı!nar efeitos pressóricos importantes ${ }^{610}$, pode-se atribuir a diferença à eficácia da AER em desviar o sangue do território hipertenso para a circulação sistêmica. Obtém-se, assim, mais uma prova indireta de que a AER determina, realmente, esse tipo de alteração hemodinâmica. Tal aspecto do problema ganhou muita importância após a demonstração no sangue portal de fatores indispensáveis para o fígado.

A maior redução pressórica obtida no grupo AER em relação ao grupo APC pode ser interpretada como conseqüência da esplenectomia. Esta por si sócausa redução de aproximadamente $30 \%$ na pressão portal em $\mathrm{EHE}^{610}$.
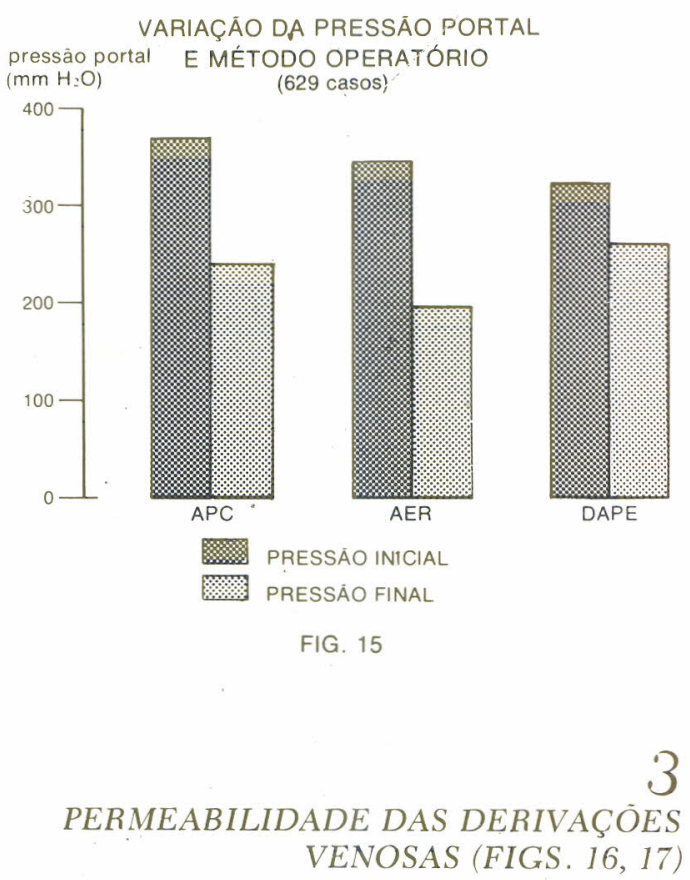

Ao todo 1.447 pacientes foram submetidos a uma derivação porto-sistêmica. Destes, 994 através de uma AER e 453 por meio de uma APC.

A permeabilidade da anastomose foi pesquisada em apenas 88 casos (9\%) do grupo AER e somente em 43 (9\%)'do grupo APC.

Estes dados, no entanto, não podem ser utilizados para calcular a incidência de trombose. Em várias publicações a permeabilidade é apenas referida, fal- 
tando informações sobre a população de operados em que foi pesquisada.

Para o grupo APC, pôde-se avaliar a incidência apenas nas publicações de Rocha ${ }^{651}$,Rosemberg e col. ${ }^{656}$ e Silva ${ }^{738}$. Esses autores pesquisaram a permeabilidade em 25 casos não selecionados encontrando três anastomoses trombosadas (12\%). Para a AER, os únicos que verificaram a permeabilidade em pacientes consecutivos ou escolhidos ao acaso fo-

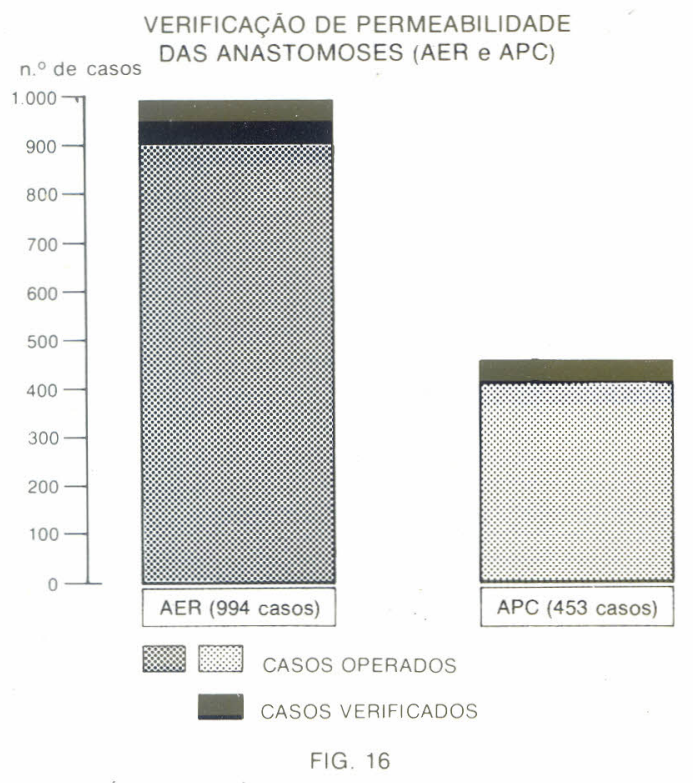

ram Shiroma e col. ${ }^{720}$, Okumura ${ }^{549}$, Speranzini 762 e Guimarães e Goffi ${ }^{320}$. Ao todo foram estudados 76 casos encontrando-se 23 (30,3\%) com trombose

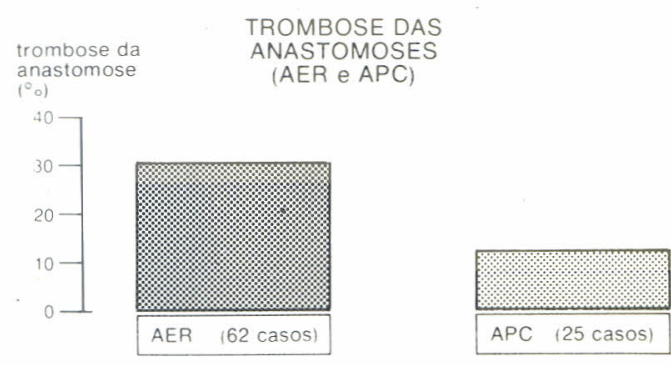

FIG. 17 da anastomose. Esta incidência parece corresponder às próprias condições técnicas e hemodinâmicas da operação, uma vez que os valores referidos são muito semelhantes entre si. De fato, as percentagens de trombose publicadas por cada um dos quatro autores situam-se entre $28,5 \%$ e $30 \%$.

\section{RESULTADOS TARDIOS}

Obviamente, a avaliação dos resultados tardios de qualquer tratamento cirúrgico depende do seguimento prolongado dos operados. Um seguimento maior adquire particular importância nos EHE, pela grande incidência da parasitose na população jovem e além disso, pelo aparecimento relativamente tardio de muitos dos efeitos cirúrgicos indesejáveis.

Entretanto, como já analisado nesse capítulo, o seguimento dos casos relatados na literatura é incompleto. A volta dos operados para controle não obedeceu critério de seleção preestabelecido nem escolha aleatória programada. Os que voltaram o fizeram por iniciativa própria. Este aspecto, entre outros, pode influir de duas maneiras opostas na amostragem seguida. Os efeitos pesquisados representam complicações clínicas. É lícito supor que maior percentagem da população afetada retorne ao hospital à procura de assistência e orientação. Pelo contrário, se o evento causar a morte, sua ocorrência reduz a percentagem de retorno.

Exemplo desta última possibilidade são os resultados de Alves ${ }^{29}$ que observou recidiva hemorrágica tardia fatal em cinco de dezesseis casos do grupo AER.

Portanto nas duas eventualidades a incidência da complicação operatória na população que volta para seguimento pode não corresponder à freqüência real do evento na população operada.

Pretendendo diminuir essas causas de erro e não podendo agir de outra forma, 
analisamos apenas os resultados das publicações com cinco ou mais casos em cada grupo e com seguimento de $50 \%$ dos casos operados pelo menos durante um ano.

\section{EFEITOS NAS HEMORRAGIAS DIGESTIVAS (Fig. 18)}

Vários autores demonstraram que a incidência de sangramento pós-operatório nos pacientes-tratados com indicação profilática é nitidamente menor que naqueles que já tinham apresentado hemorragia antes da operação. ${ }^{403} 718$ Desta forma, limitamos o estudo deste aspecto aos pacientes com indicação terapêutica. Além disso, excluímos os casos falecidos no pós-operatório imediato por outra causa que não hemorragia precoce. Assim, a população analisada restringiu-se aos sobreviventes e aos casos falecidos por hemorragia no pós-operatório imediato.

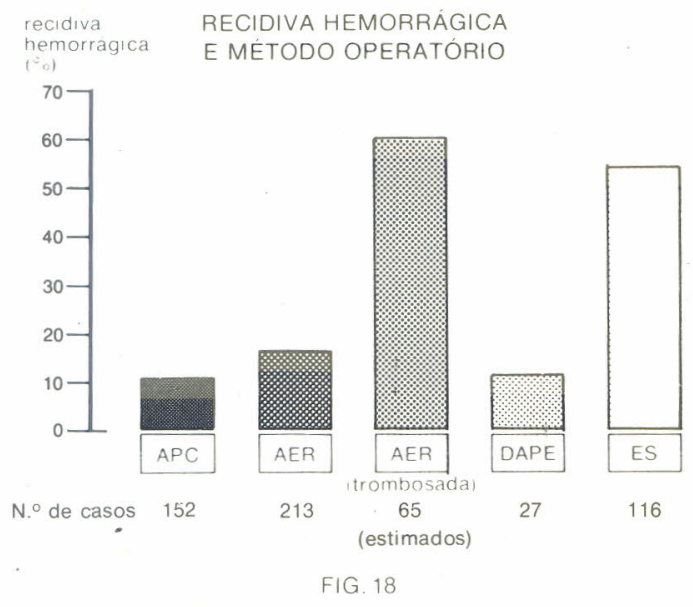

Com raras exceções não foram encontradas referências à pesquisa endoscópica para diagnóstico etiológico da hemorragia em curso. Permanecem, desta forma, sérias dúvidas sobre a responsabilidade das varizes de esôfago no desencadeamento do processo. Aceita-se que aproximadamente $50 \%{ }^{736}$ dashemorragias em pacientes com hipertensão portal e não operados sejam decorrentes de outras causas. Destacam-se entre elas a gastrite hemorrágica e as úlceras pépticas gastroduodenais ${ }^{552}$.

APC - Apenas cinco autores: Rocha $^{651}$, Teixeira ${ }^{793}$, Warren e col. ${ }^{846}$, Didier $^{194}$ e Silva ${ }^{739}$ apresentaram resultados segundo o critério adotado (pág. 20 ). Não mencionam, porém, controle de permeabilidade da anastomose. Dos 152 casos coletados, dezesseis $(10,5 \%)$ revelaram novamente hemorragia digestiva, mas apenas 36 foram acompanhados durante 5 anos. Silva ${ }^{739}$ foi o único que referiu exame endoscópico de urgência. Demonstrou que três dos cinco casos recidivantes sangraram por outras causas que não varizes de esôfago.

Goffi ${ }^{293}$, pelo contrário, estudou um grupo de dez pacientes selecionados com indicação terapêutica e anastomose comprovadamente pérvia. Não referiu nenhuma recidiva durante um período de "trinta dias a 48 meses" (seguimento médio de 19,3 meses).

No material estudado, a APC apresentou-se trombosada, em $12 \%$ dos casos. Desta forma estima-se que, dos 152 pacientes acompanhados sem controle de permeabilidade, provavelmente, dezoito apresentaram trombose de sua anastomose. Supondo-se que a maioria dos dezesseis recidivantes pertençam a este grupo, a incidência estimada de recidiva hemorrágica na população com APC trombosada eleva-se para $88 \%$.

AER - Sempre obedecendo o critério programado, separaram-se os resultados de Rocha ${ }^{652}$, Alves ${ }^{29}$, Teixeira ${ }^{793}$, Didier $^{194}$ e Shiroma ${ }^{718}$ perfazendo um total de 213 sobreviventes sem estudo de permeabilidade. Em 34 casos desta população (16\%), verificou-se recidiva hemorrágica em diferentes épocas do pósoperatório. Este porém foi seguidodurante cinco anos em apenas 78 casos distribuídos em cinco publicações. 
Da mesma forma que para o grupo APC os pacientes com AER pérvia com: provada não apresentaram novas hemorragias. Assim Goffi ${ }^{293}$ e Guimarães e Goffi ${ }^{320}$ referem um total de 32 casos selecionados, com indicação terapêutica, seguidos de um a quatro anos sem sangramento após a cirurgia.

Para o grupo AER a percentagem de trombose oscila ao redor de $30 \%$. Assim, dos 213 sobreviventes, provavelmente 65 apresentaram oclusão do óstio anastomótico que transforma a operação tentada numa ES. Se extrapolarmos para este raciocínio a informação da falta de recidivas nos pacientes com AER pérvia, deduz-se que naqueles com AER ocluída o evento ocorreu com freqüência ao redor de 52\%. É interessante que esta estimativa se aproxima bastante do valor de $56 \%$, referido logo adiante, para a incidência pós-operatória no grupo ES.

Vimos, assim, que a recidiva estimada nas anastomoses trombosadas é diferente conforme o tipo de derivação. Na APC estimou-se um valor de $88 \%$, enquanto que para a AER este oscilou ao redor de $52 \%$. Nesta última, a esplenectomia por si só reduz a pressão portal em aproximadamente $30 \%$ 610 e a trombose não impede a persistência do fluxo hepatopetal. Pelo contrário, nos pacientes com APC ocluída, além da elevação da pressão portal mais acentuada todo o retorno venoso do sistema porta é forçado através das vias colaterais, inclusive pelo território gastresofágico.

DAPE - Apesar da grande divulgação deste método operatório no país e no exterior apenas os resultados de Alves ${ }^{29}$, e Guimarães ${ }^{319}$, obedeceram o critério programado. Dos 27 casos relatados, três (11\%) apresentaram recidiva pósoperatória. Todavia, nenhum dos pacientes foi seguido durante cinco anos. O primeiro autor acompanhou quatro de seus casos durante um ano, quatro até dois anos e cinco por um período entre dois e três anos. O segundo referiu apenas estudo dos resultados durante um ano, não fazendo referências a seguimento ulterior.

A maioria dos autores que defende esta operação não refere seguimento correlacionável com cada caso ou analisa em conjunto cirróticos e EHE.

Considerando a divulgação do método, resolvemos citar também algumas das "impressões clínicas" mencionadas pelos autores com maior casuística. Citamse incidências de recidiva hemorrágica em 7,9\% (133 casos), 10\% (393 casos), $19 \%$ (63 casos), 19,6\% (quarenta casos) e $30,7 \%$ (treze casos).

A interpretação desses valores não prescinde das informações constantes no capítulo 2.3 sobre a revascularização esôfago-gástrica após desconexão ázigoportal. O caráter progressivo do processo desperta dúvidas quanto à persistência dos bons resultados referidos durante curtos períodos de seguimento. Acreditamos oportuno insistir que nenhuma das publicações relativas às “impressões clínicas" informa sobre seguimento de cinco anos e com retorno de pelo menos $50 \%$.

ES - Dos 116 casos compilados, 63 $(54.3 \%)$ apresentaram recidiva hemorrágica durante o período estudado, sendo que quarenta foram acompanhados durante cinco anos.

A alta incidência não surpreende. Após a retirada do baço, a pressão portal permanece elevada ao redor de $230 \mathrm{~mm} . \mathrm{H}_{2} \mathrm{O}$.

\section{EFEITOS NEUROPSÍQUICOS (FIG. 19)}

As complicações neuropsíquicas decorrem fundamentalmente do desvio do sangue portal para a circulação sistêmica. Conseqüentemente, seu aparecimento depende da permeabilidade da anastomose. Esse fato aconselha dividir o grupo AER em dois subgrupos respecti- 
vamente com permeabilidade comprovada ou não. Para o grupo APC, este cuidado foi considerado desnecessário devido ao pequeno número de sobreviventes com anastomose ocluída.

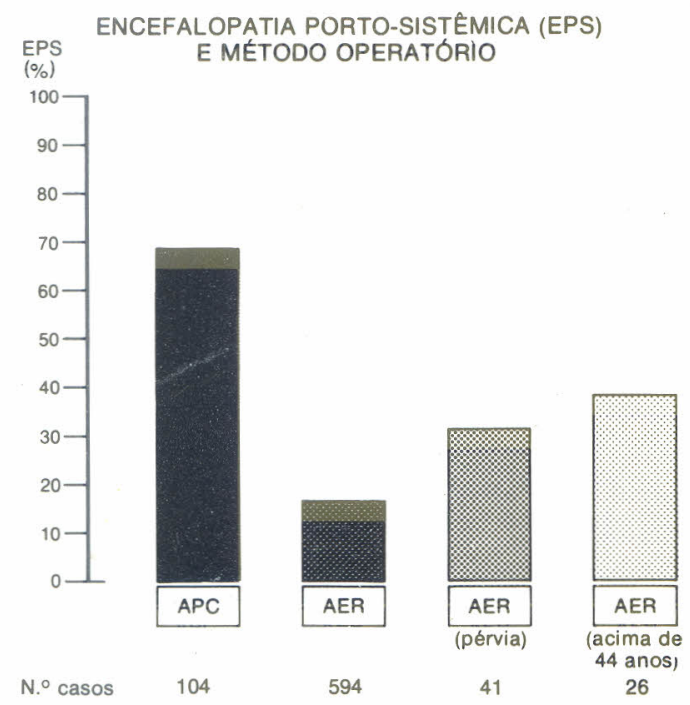

FIG. 19 daquela idade, a complicação foi verificada em dez (38,5\%). Nas casuísticas referidas por Goffi 293 e Guimarães ${ }^{319}$ incluindo casos selecionados com anastomose comprovadamente pérvia, a EPS foi observada em doze (29\%) dos 41 estudados.

Correlacionando estes dados com os referentes à incidência de trombose no grupo AER, podem-se obter informações adicionais. Dos 584 casos do grupo AER, provavelmente $179(30,6 \%)$ apresentaram trombose da anastomose: Desta forma, a incidência estimada de EPS nos 405 casos com anastomose pérvia deve ser igual a $24 \%$. A diferença entre os valores obtidos no grupo AER com anastomose comprovadamente pérvia $(29 \%)$ e os estimados para os casos provavelmente não ocluídos (24\%) pode ser conseqüente à inclusão no primeiro de pacientes sem limite de idade.

\section{3 EFEITOS NO HIPERESPLENISMO (FIG. 20)}

Devido à sua importância, os resultados concernentes a este aspecto foram analisados, mais adiante, em capítulo dados suficientemente claros sobre a técnica empregada, não foi possível verificar se este comportamento ocorre também nos EHE.

Conforme o critério estabelecido, reuniram-se os dados de Machado ${ }^{457}$, Goffi ${ }^{293}$, Didier ${ }^{194}$ e Silva ${ }^{739}$. O grupo compreende 104 operados dos quais 72 (69\%) apresentaram alterações neuropsíquicas. Em 30\% destes últimos, referiram-se sintomas com intensidade suficiente para rotular a síndrome como de tipo grave.

AER - As casuísticas sem controle de permeabilidade publicadas por Shiroma e col. ${ }^{720}$, Okumura ${ }^{549}$ e Shiroma, ${ }^{718}$, citam um total de 594 pacientes operados com menos de 44 anos. Nestes, a EPS ocorreu em 98 (17\%). Nos 26 casos acima

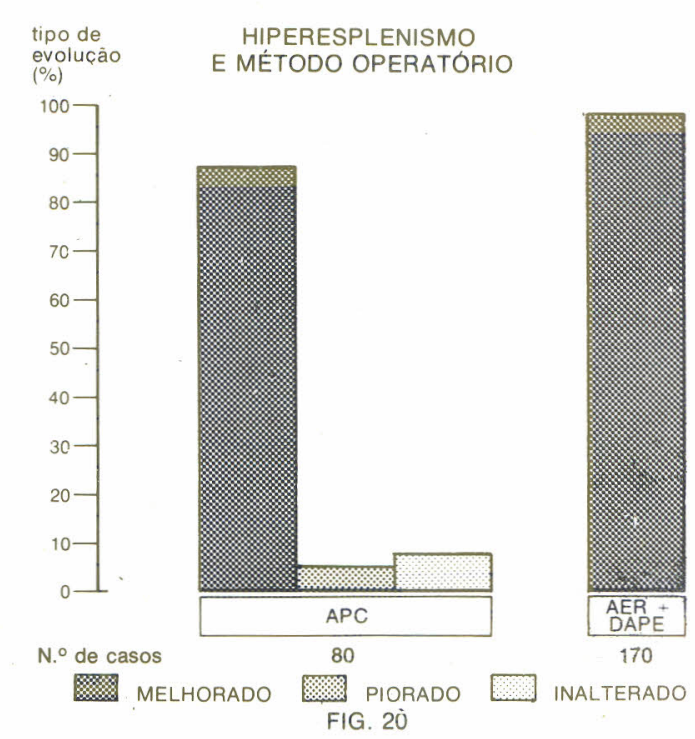


próprio. Apesar disto, serão citados também neste tópico alguns dados para avaliação geral dos métodos terapêuticos.

A maioria dos autores diagnostica a síndrome apenas pela contagem de leucócitos isolada ou associada à contagem de plaquetas.

APC - Nos oitenta casos descritos em seis publicações, refere-se persistência do quadro em $87,5 \%$, melhora em $5 \%$ e piora em 7,5\%. Neste último grupo, estudou-se adicionalmente o comportamento pós-operatório da hemólise.

AER e DAPE - Como nestas técnicas o baço é retirado, reuniram-se as casuísticas correspondentes, resultando um grupo de 170 pacientes em oito publicações. Como esperado, a quase totalidade das observações $(98,8 \%)$ refere melhora ou regressão completa do hiperesplenismo.

\section{EFEITOS NA FUNÇÃO HEPÁTICA}

A avaliação deste parâmetro é muito difícil. Aceita-se atualmente que apenas as assim chamadas provas de função máxima conseguem aferir a massa funcional hepática total670-823. As provas laboratoriais comumente empregadas pesquisam diferentes linhas metabólicas evidenciando apenas alterações relativamente grosseiras, que teoricamente só deveriam ocorrer após longos períodos de pósoperatório quase nunca analisado no material desta revisão.

Apesar disto, serão comentadas algumas das informações disponíveis. Muito provavelmente foram baseadas na impressão clínica dos autores, Não é impossível, entretanto, que essa impressão tenha-se baseado, pelo menos em parte, na elevação das taxas de bilirrubinas. Entretanto a hemólise reconhecidamente presente depois de alguns métodos operatórios pode ter representado causa de erro na avaliação do problema.

$\mathrm{APC}$ - A maioria dos oito autores que divulgaram resultados de 125 casos cita piora na função hepática após cirurgia. Em todos os 99 casos $(79,2 \%)$ seguidos ( $56 \%$ por mais de um ano), refere-se alteração de uma ou mais das provas laboratoriais. 193-293-457-609-656-739-846.

AER - Apenas dois autores 293319 estudaram este aspecto da questão. O primeiro acompanhou 27 casos durante um periodo médio de 20 meses e o segundo estudou 12 casos durante um ano. Ambos referem preservação da função hepática após a cirurgia.

As informações disponíveis sobre os resultados do tratamento cirúrgico em EHE não permitem conceituação exata e completa do problema.

Não foram realizados ainda estudos clínicos programados com metodologia científica atualizada. Esta deficiência pode ser conseqüente, pelo menos em parte, ao caráter migratório da população estudada, o que dificulta seguimento suficiente.

No entanto, os dados coletados sugerem pelo menos um aspecto médico-social muito importante. A ES é a operação com maior número de casos publicados, sendo ainda realizada em muitos centros do país apesar de apresentar recidivas hemorrágicas em pelo menos $56 \%$ dos casos.

Além disso, torna-se aparente que os maus resultados devem-se a dois aspectos fundamentais. As derivações controlam as hemorragias mas causam alterações neuropsíquicas com incidência proibitiva. A esplenectomia simples associada ou não à desconexão ázigo-portal não determina efeitos neurológicos, porém é incapaz de controlar satisfatoriamente os fenômenos hemorrágicos.

Desta forma, para procurar uma solução para o problema cabe analisar a fisiopatologia dos efeitos colaterais determinados pelo desvio do sangue portal e o mecanismo pelo qual se restabelecem as comunicações venosas após a desconexão ázigoportal. 
REFERÊNCIA BIBLIOGRÁFICA DAS PUBLICAÇÕES ANALISADAS

$\begin{array}{llccccccccccr}1 & 2 & 3 & 4 & 5 & 6 & 7 & 8 & 9 & 10 & 16 & 20 & 21 \\ 22 & 23 & 26 & 28 & 29 & 30 & 31 & 44 & 45 & 46 & 47 \\ 48 & 62 & 93 & 94 & 106 & 114 & 122 & 125 & 133 & 148 \\ 151 & 152 & 153 & 155 & 179 & 182 & 192 & 193 & 194 \\ 195 & 224 & 225 & 228 & 241 & 242 & 266 & 271 & 274 \\ 275 & 276 & 277 & 292 & 293 & 294 & 297 & 299 & 300 \\ 301 & 302 & 303 & 304 & 319 & 320 & 325 & 340 & 347 \\ 393 & 396 & 399 & 403 & 404 & 405 & 406 & 418 & 424 \\ 436 & 454 & 456 & 457 & 467 & 468 & 485 & 510 & 517 \\ 544 & 547 & 548 & 549 & 552 & 583 & 589 & 590 & 594 \\ 607 & 609 & 610 & 615 & 616 & 623 & 624 & 651 & 652 \\ 653 & 656 & 718 & 720 & 737 & 738 & 739 & 740 & 769 \\ 762 & 779 & 791 & 793 & 794 & 799 & 800 & 815 & 816 \\ 818 & 828 & 829 & 833 & 846 & 902 & & & \end{array}$


26 Estado Atual da Questão 


\section{EFEITOS DO DESVIO DO SANGUE PORTAL PARA AVEIA CAVA INFERIOR (FÍSTULA DE ECK)}

Desde o século passado, sabe-se que vários animais de laboratório não sobrevivem à ligadura súbita da veia porta. Claude Bernard já tinha previsto que a rápida evolução era conseqüente à estagnação venosa no sistema porta (Fig. 21) e não à interrupção do fluxo portal para o fígado. Sugeriu que o desvio deste sangue para a circulação sistêmica evitaria a morte do animal. Não conseguiu provar esta hipótese, pois não dispunha de recursos técnicos suficientes para realizar a operação. Esta só foi executada, em 1877, por Nikolai Vladimirovich Eck ${ }^{128}$ que pretendia encontrar uma solução para a ascite. Trabalhando em cães, ligou a veia porta junto ao fígado. Uniu seu coto distal à veia cava inferior através de uma anastomose término-lateral, conhecida desde então com o nome de Fístula de Eck (FE) (Fig. 22). Operou oito animais, dos quais sete faleceram no pós-operatório imediato e o oitavo fugiu do biotério dois meses e meio depois da cirurgia. Apesar da inconsistência desses resultados, publicou, no Jornal Médico de São Petersburgo, uma súmula dos seus trabalhos, que termina com as seguintes palavras:

"Considero terem sido removidas as dúvidas para a realização desta operação no homem, porquanto ficou demonstrado que o sangue da veia porta pode ser desviado diretamente para a circulação sistêmica sem nenhum perigo para o organismo e através de uma operação perfeitamente segura"128.
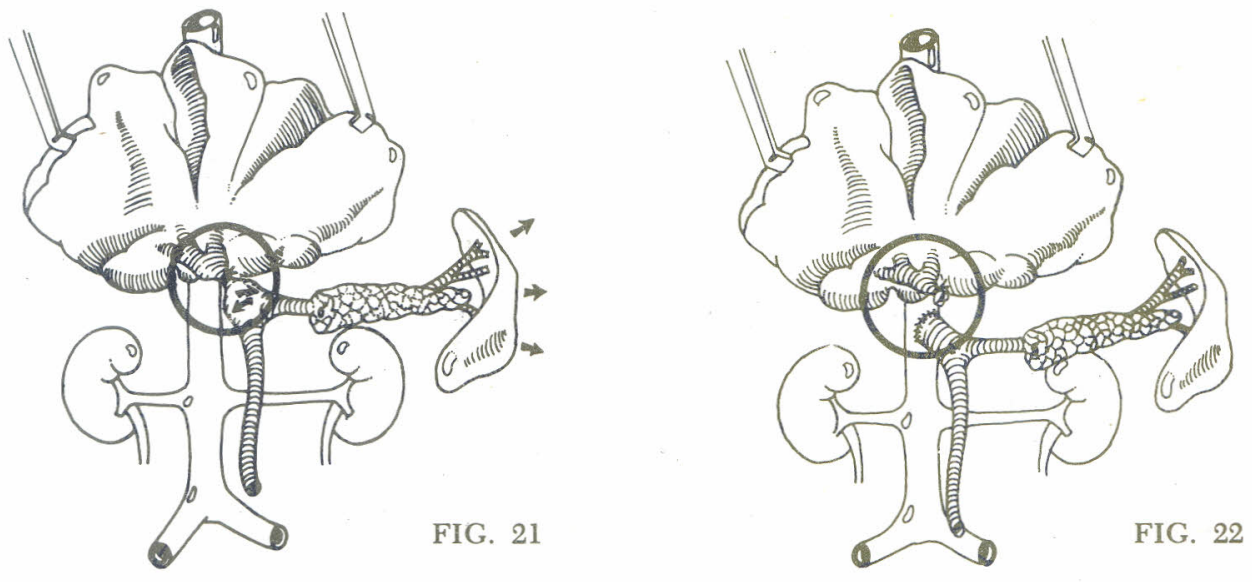
A primeira contestação a este conceito injustificado foi feita pelo grupo de $\mathrm{Pa}$ vlov em 1893 ${ }^{326}$. Realizou estudos minuciosos sobre os efeitos da FE em sessenta cães e notou que os animais morriam em poucos meses, após uma seqüência característica de graves sintomas.

Nos últimos oitenta anos este resultado foi confirmado por uma sucessão ininterrupta de investigações experimentais e clínicas que acumularam uma verdadeira massa de dados e informações. Apesar disso, apenas nos últimos anos foi reconhecida a dependência das células hepáticas no aporte direto de sangue portal. Este atraso de quase um século foi conseqüente a uma série de afirmações feitas por autores de grande prestígio que defenderam, como Eck, a inocuidade do desvio do sangue portal.

Whipple e seu grupo foram os pioneiros na aplicação da FE no homem ${ }^{872-873}$. que clinicamente é conhecida pelo nome de Anastomose Porto-Cava TérminoLateral (APC) (Fig. 8). Interpretaram a excelente preservação hepatocelular de pacientes com trombose da veia porta (Fig. 23) como prova de que o sangue portal não era necessário para o fígado e, portanto, podia ser impunemente desviado para a veia cava. Mais tarde, no seguimento tardio dos primeiros cirróticos operados, observaram-se alterações neurológicas e piora da função hepática interpretadas por Blakermore ${ }^{69}$ como devidas à evolução natural da moléstia e não ao desvio do sangue portal .

Finalmente, Child III e col. ${ }^{130}$ apresentaram resultados obtidos em cães com transposição porto-cava total (Fig. 24). Observaram que a substituição do sangue portal por igual volume de sangue sistêmico impedia os efeitos deletérios da FE na regeneração hepática. Citaram esłe comportamento como prova de que o sangue portal não continha fatores indispensáveis para as células hepáticas.

Entretanto, a aquisição de conhecimentos inéditos nos últimos anos permitiu refutar aqueles argumentos e a demonstração de fatores hepatotróficos no sangue portal modificou a questão ${ }^{765}$. O caráter hormonal de tais substâncias faz crer que a preservação de pequena parcela do fluxo hepatopetal é suficiente para impedir os efeitos do desvio. Assim, na trombose da veia porta, a pequena quantidade de sangue que ultrapassa o obstáculo através de recanalização (Fig. 25) explica a preservação

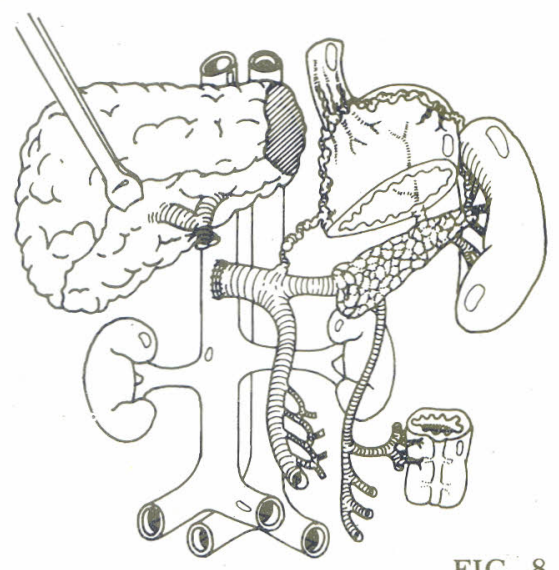

FIG. 8

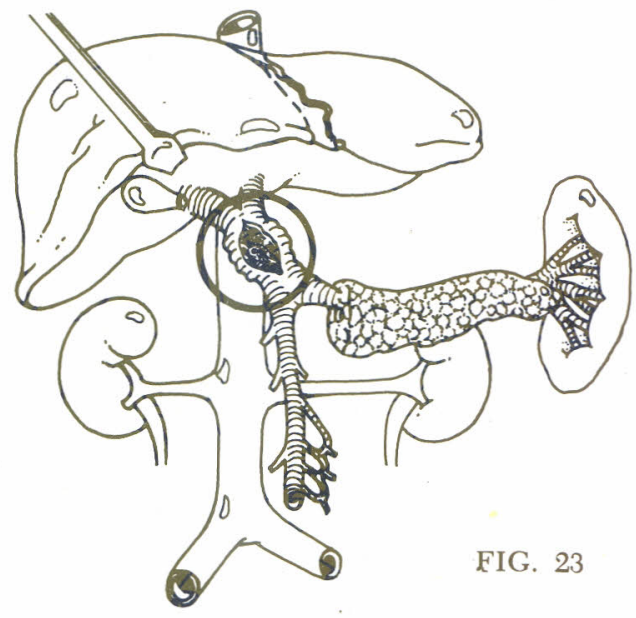



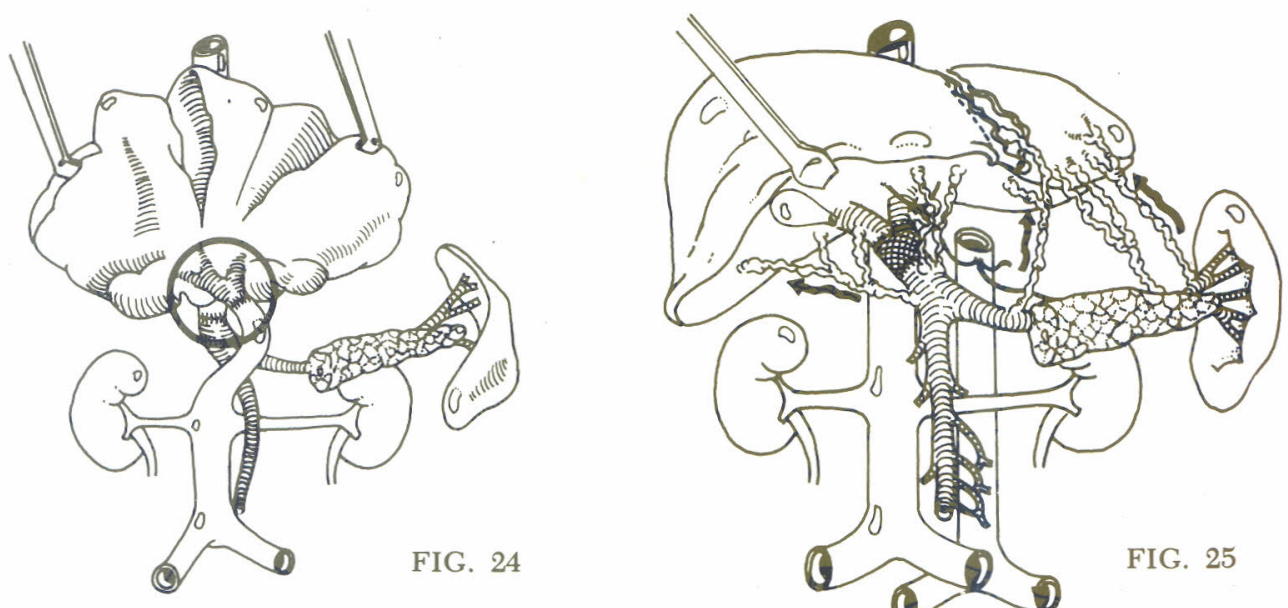

FIG. 24

FIG. 25

hepática. Da mesma forma, estudos prospectivos demonstraram que os efeitos pósoperatórios atribuídos à evolução natural das cirroses são, na realidade, conseqüentes ao desvio do sangue portal uma vez que não aparecem com a mesma intensidade e freqüência nos controles não operados ${ }^{144-633}$. Finalmente, o modelo de Child empregado para estudos de outros efeitos, além da influência na capacidade de regeneração, mostrou claramente a dependência do trofismo das células hepáticas em vários componentes do sangue portal ${ }^{712-765}$.

É interessante a coincidência cronológica da enunciação dos novos princípios fisiopatológicos com a divulgação dos resultados da Descompressão Portal Seletiva (DPS). A análise retrospectiva desses acontecimentos sugere que o novo tratamento cirúrgico aumentou a receptividade dos cirurgiões para discussão e para análise mais cuidadosa dos resultados obtidos com os métodos terapêuticos previamente adotados. Provavelmente, a disponibilidade de uma alternativa técnica igualmente eficaz tenha abolido a necessidade de justificar as derivações clássicas', que até então, eram as únicas capazes de oferecer bons resultados no controle das hemorragias. Este ponto de vista explica o atraso com que foi valorizada a demonstração das graves conseqüências fisiopatológicas da FE.

A maioria dos métodos atualmente utilizados no tratamento cirúrgico das varizés de esôfago desvia, em todo ou em parte, o sangue portal para a circulação sistêmica. A aceitação desta afirmação é básica e aumenta o interesse pelo estudo dos efeitos decorrentes daquele desvio. Assim, os métodos operatórios podem ser divididos em três grupos. O primeiro inclui aqueles que reconhecidamente desviam todo o sangue portal. O segundo grupo compreende os métodos que desviam apenas parte daquele sangue. E, finalmente, compõem o terceiro grupo os métodos operatórios que reconhecidamente não desviam o sangue portal. No primeiro grupo inclui-se a APC (Figs. 26-27). No último, a esplenectomia simples (Figs. 28-29) e a desconexão ázigo-portal de qualquer tipo (Figs. 30-31). O grupo intermediário é representado pela Anastomose Espleno-Renal (AER), pela Anastomose Mesentérico-Cava com ou sem interposição de prótese (AMC) e a Anastomose Porto-Cava Látero-Lateral (APCLL). Discute-se muito a percentagem do sangue portal desviado por cada uma. Nos Esquistossomóticos Hepatesplênicos (EHE), a controvérsia nasceu da ausência 


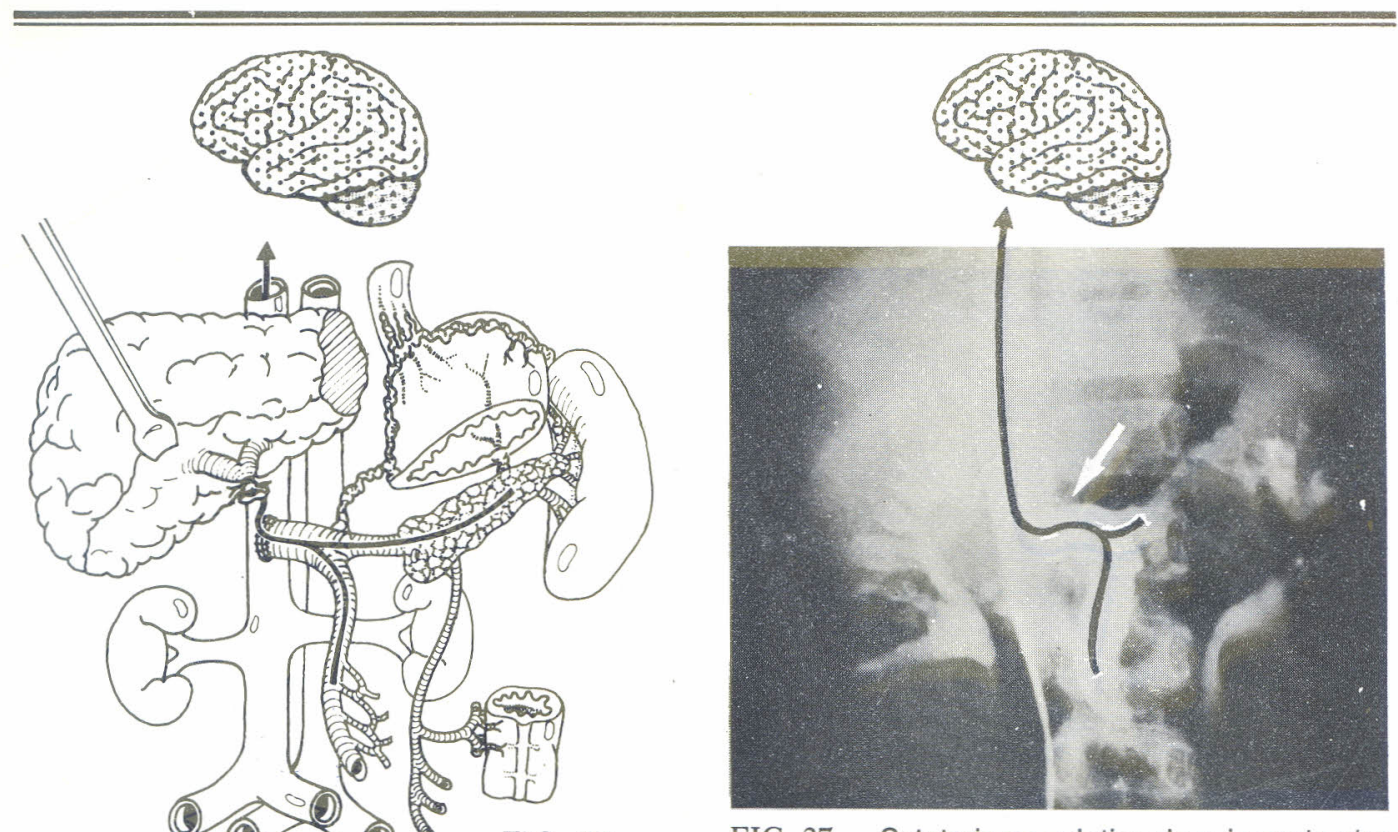

FIG. 27 - Cateterismo seletivo da veia porta através da anastomose porto-cava (seta branca).
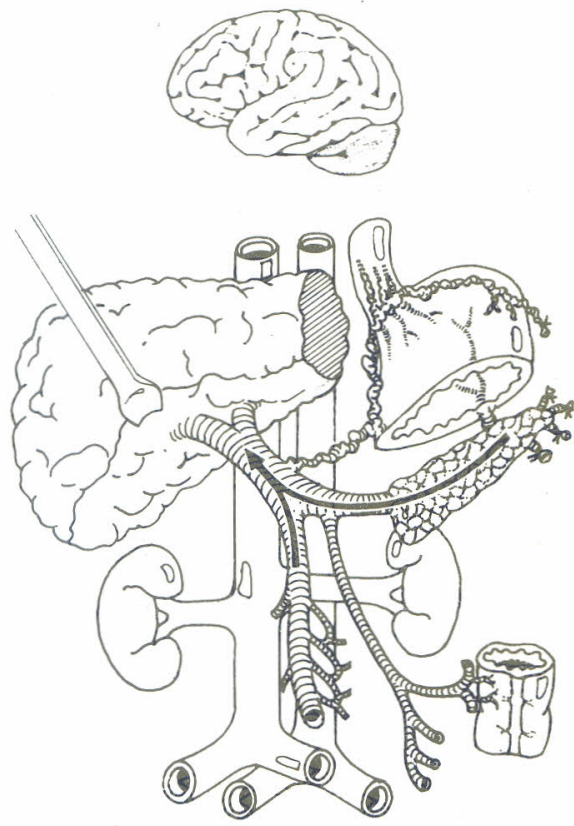

FIG. 28
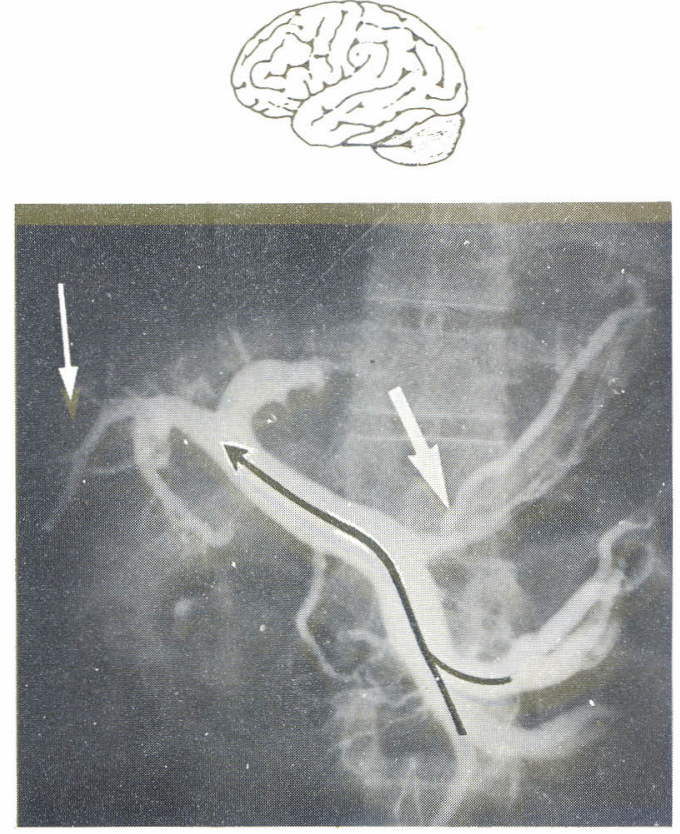

FIG. 29 - Cateterismo seletivo da veia mesentérica superior por punção trans-hepática (seta branca fina). Notar a ausência da veia esplênica e o enchimento da veia gástrica esquerda (setabranca grossa). 

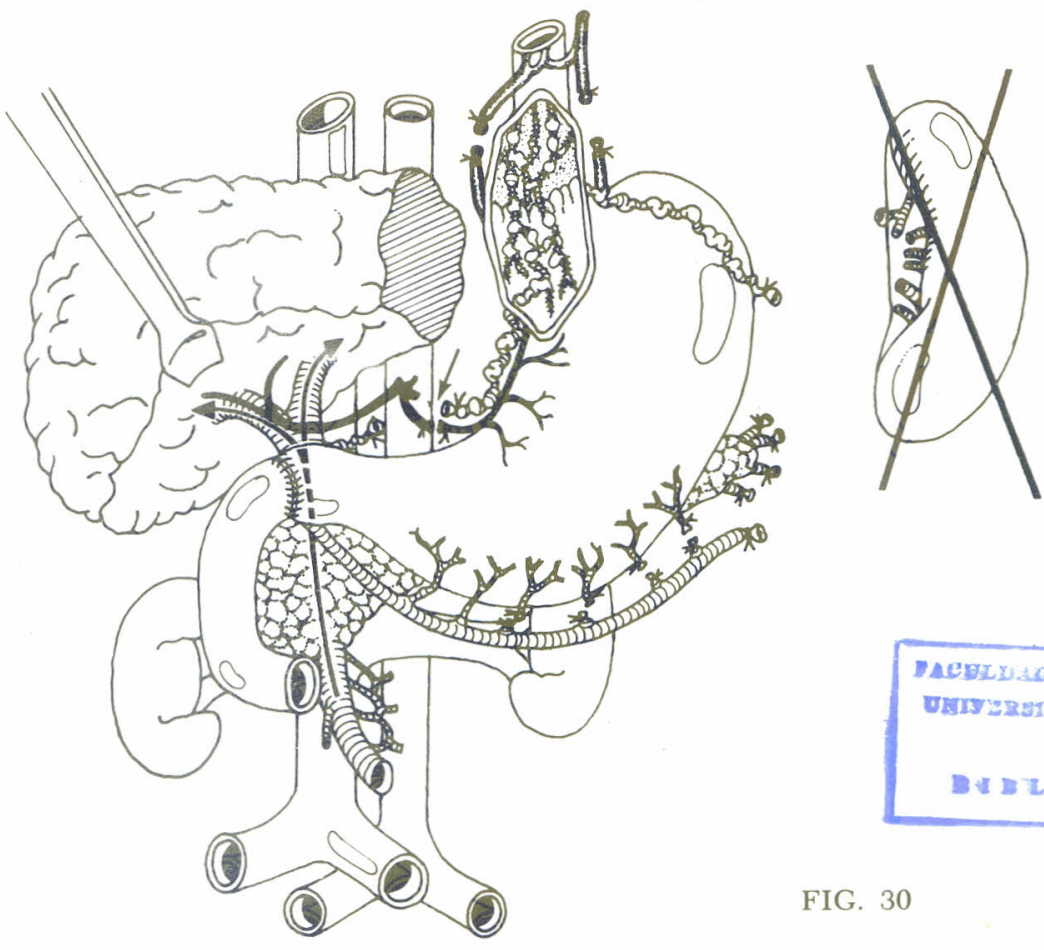

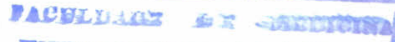

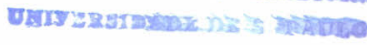

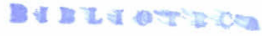

FIG. 30
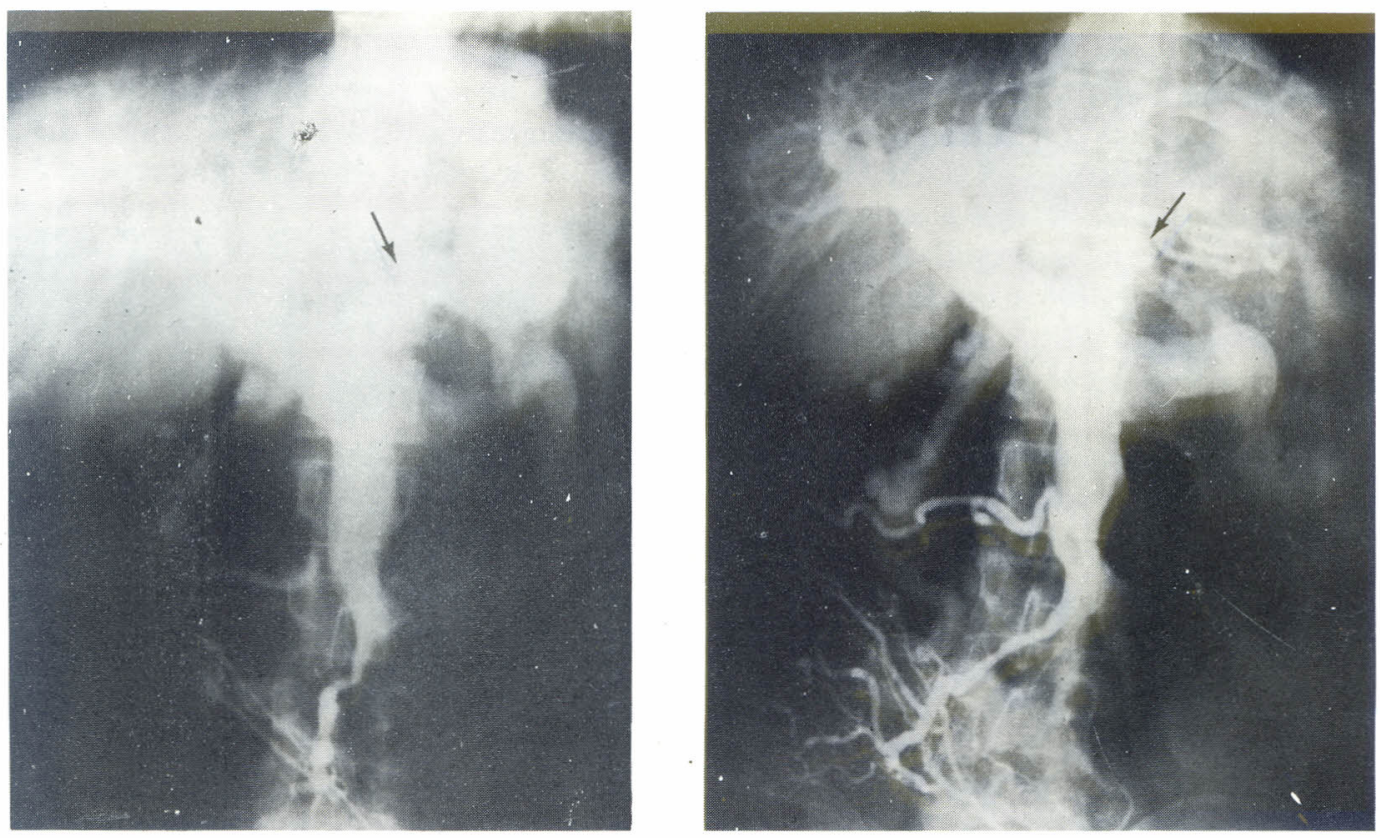

FIG. 31 - Portografia intra-operatória por cateterismo de veia ileal. A - Antes da desconexão ázigoportal. Notar a veia gástrica esquerda muito dilatada (seta). B - Aspecto final. Notar o coto da veia gástrica esquerda ligada (seta). 

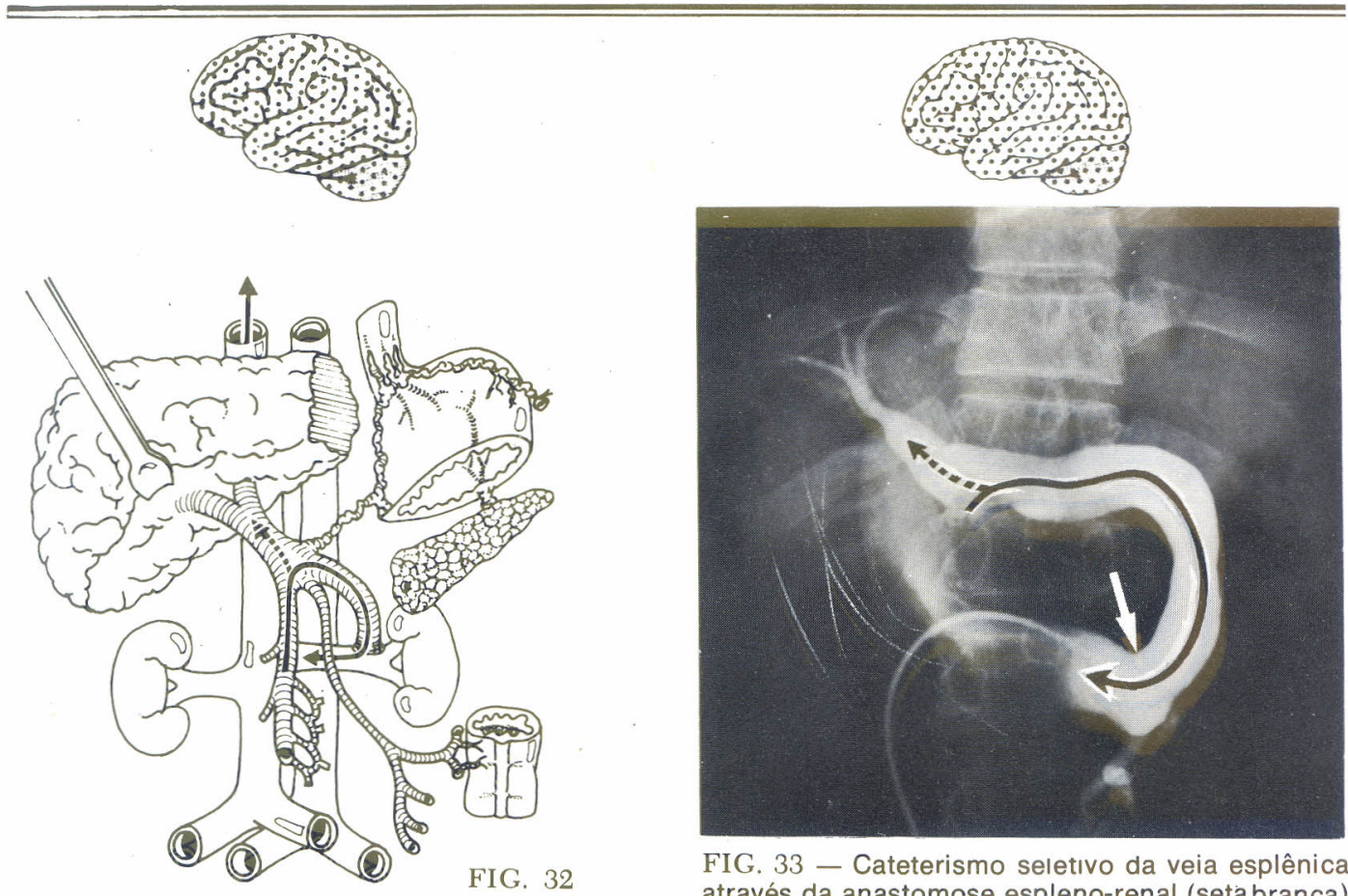

FIG. 33 - Cateterismo seletıvo da veia esplênica através da anastomose espleno-renal (setabranca).
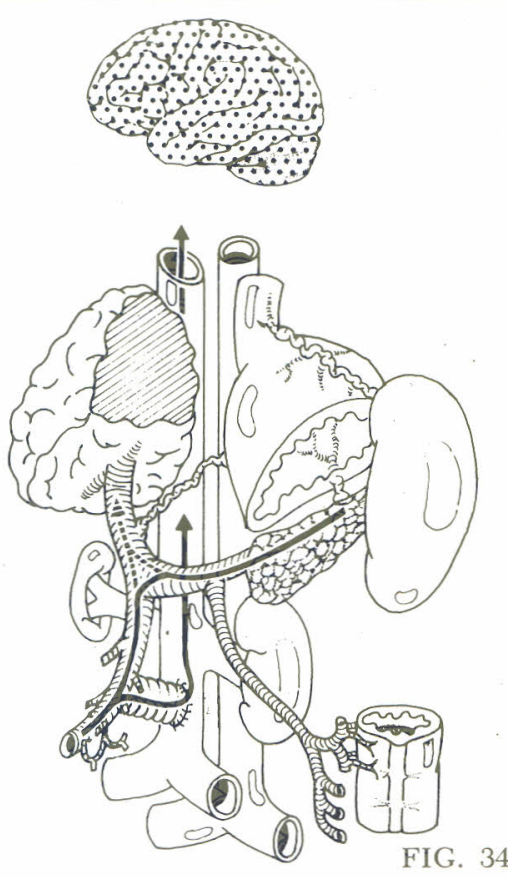
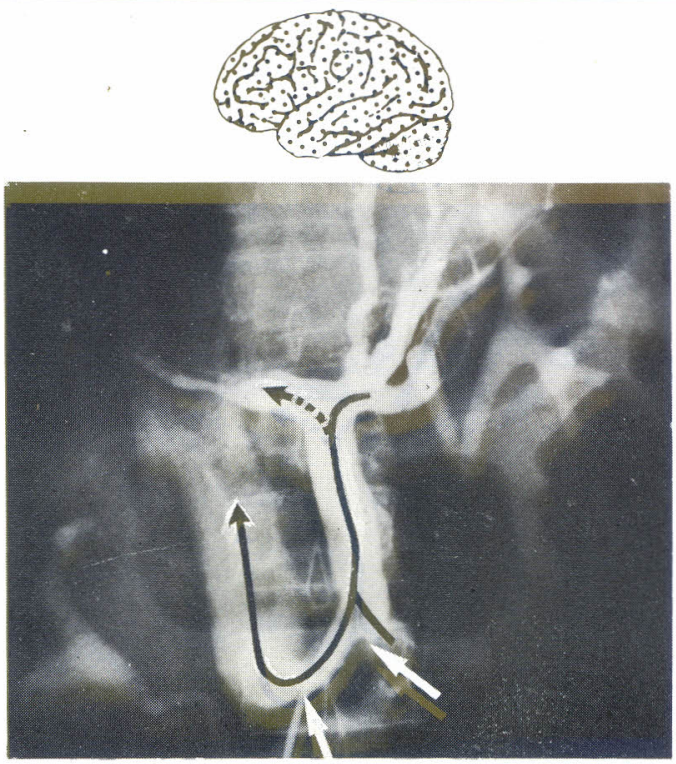

FIG. 35 - Cateterismo seletivo da veia mesentérica superior através da anastomose mesentéricocava com interposição de prótese (entre as setas brancas). 


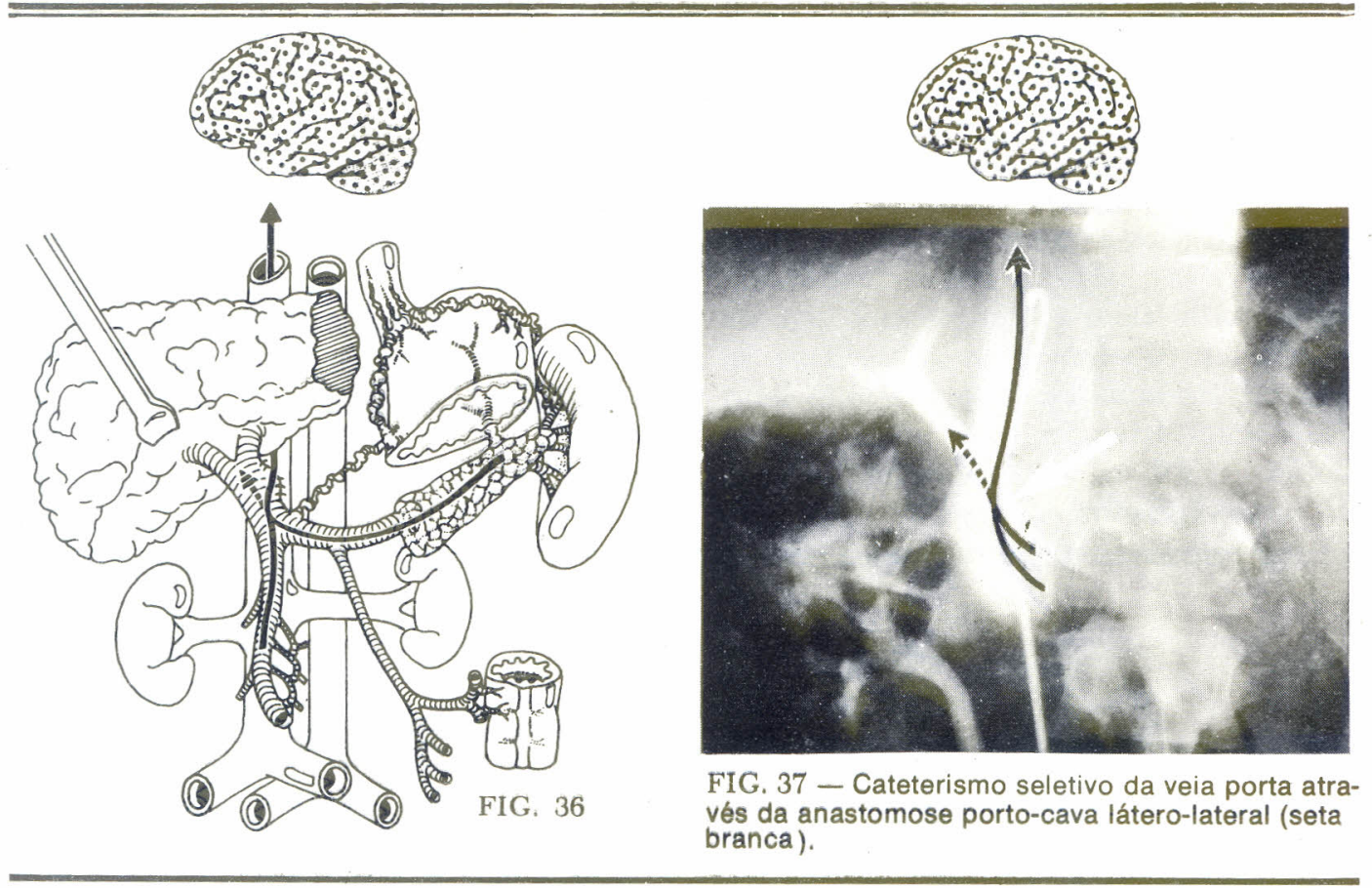

de informações precisas pois faltavam recursos técnicos para obtê-las. Nos últimos anos, porém, aplicaram-se métodos propedêuticos mais adequados. As informações, ainda que em pequeno número, mostraram-se bastante uniformes, permitindo já algumas conclusões. Demonstrou-se que a AER (Figs. 32-33), a AMC (Figs. 34-35) e a APCLL (Figs. 36-37) desviam praticamente todo o sangue portal.

A comprovação hemodinâmica foi obtida por cateterismo da anastomose através da veia cava inferior empregando-se a técnica de Seldinger e injetando o contraste a montante à anastomose. Demonstrou-se seu trajeto por radiografias seriadas (2 a 3 chapas/seg) ou por cineangiografia (24 quadros/seg). Verificou-se falta de perfusão hepática de duas maneiras: pelo trajeto seguido pelo contraste e pela estagnação na árvore portal intra-hepática (observou-se parada do contraste durante períodos de até vinte segundos ${ }^{500}$ ).

Com a intenção de facilitar a análise dos dados apresentados, dividimos a questão em duas partes dedicadas:

- aos efeitos nas células hepáticas conseqüentes à falta de sangue portal;

- aos efeitos da chegada direta do sangue portal na circulação sistêmica. 
34 Estado Atual da Questão 


\section{Efeitos nas celulas hepáticas consequientes à falta de sangue portal}

Em condições normais o fígado possui dupla irrigação. Uma através da veia porta e outra através da artéria hepática (Fig. 38). No homem o fluxo hepático total é estimado em cerca de $1.500 \mathrm{ml} / \mathrm{min}$ 56-104, dos quais aproximadamente 65\% representam o componente portal e $35 \%$ o arterial 697-824. nios produzidos pelo tubo digestivo e glândulas anexas. Contém esses elementos em concentrações mais altas do que as verificadas na circulação arterial, na qual chegam após clareamento hepático e diluição na circulação sistêmica. Assim sendo, nos modelos com FE as células hepáticas sofrem as conseqüências de-
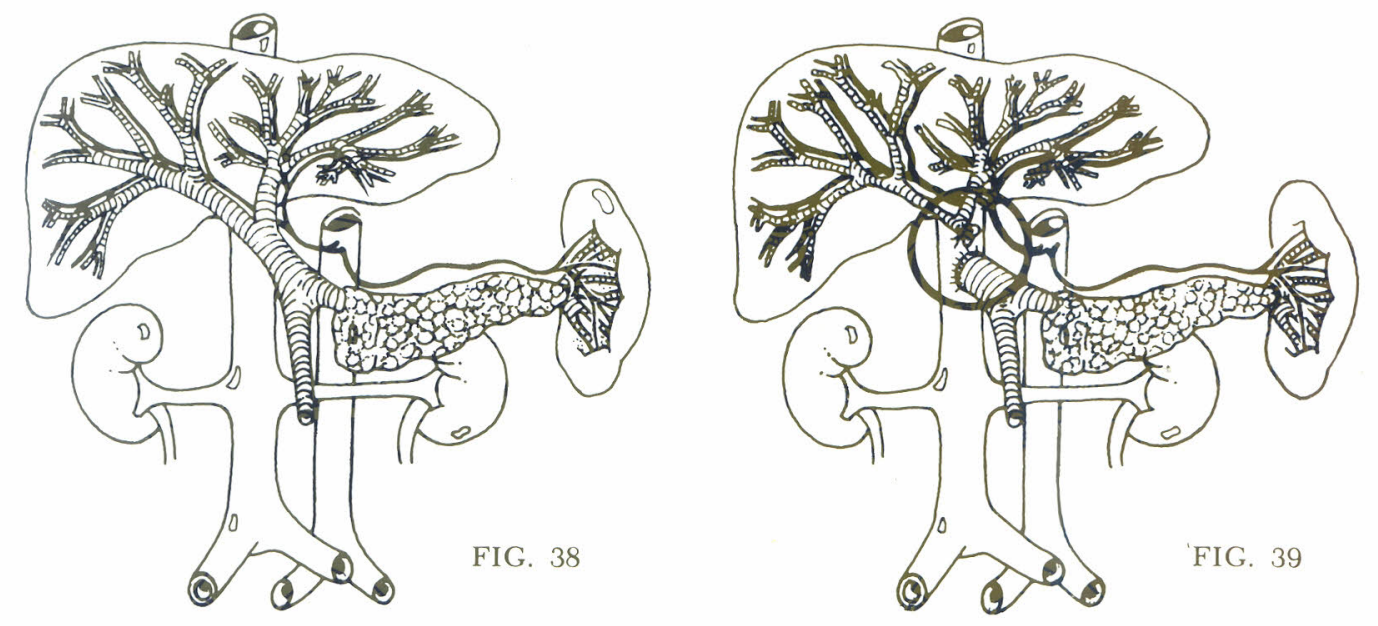

A FE desvia o sangue do sistema porta para a veia cava e modifica radicalmente as condições hemodinâmicas do fígado. Sua irrigação passa a depender exclusivamente da artérià hepática (Fig. 39). Em fígados cirróticos, e nestas circunstâncias, ocorre aumento de $48 \%$ no fluxo da artéria hepática ${ }^{603}$ como resultado da exclusividade de trânsito pelos sinusóides hepáticos ${ }^{697}$. O acréscimo, entretanto, não impede que o fluxo hepático total diminua de aproximadamente $46 \%$ 640 ou $57 \% 697$.

O sangue portal difere do sangue arterial em vários aspectos bioquímicos. Além das substâncias recém-absorvidas no intestino, recebe diretamente hormô- terminadas pela redução no fornecimento de vários substratos e hormônios. Tais efeitos podem ser divididos em três grupos principais: morfológicos, funcionais e na capacidade de regeneração.

EFEITOS MORFOLÓGICOS

1

Nos últimos cem anos nunca se confirmaram as observações de Eck sobre a falta de conseqüências do desvio do sangue portal para a circulação sistêmica e já em 1893, o grupo de Pavlov questionou esta inocuidade ${ }^{326}$. Desde então, 


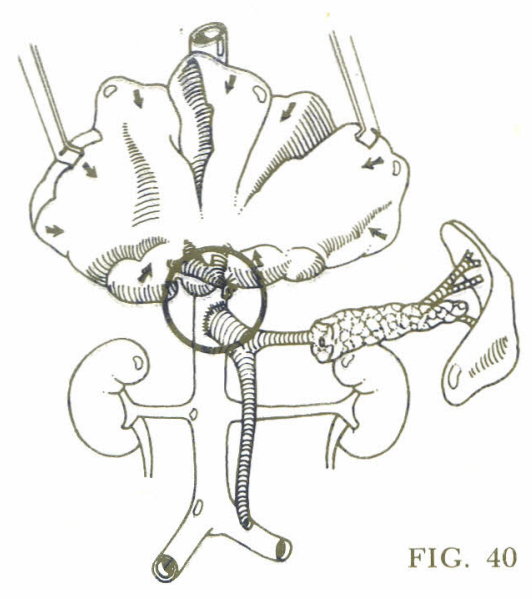

acumularam-se dados demonstrando que a FE causa importantes efeitos morfológicos nas células hepáticas.

Devido ao grande número, dividimos as informações disponíveis em três partes, conforme a sucessão cronológica com que apareceram na literatura. A primeira compreende o período da contestação à inocuidade do desvio e a descrição dos efeitos morfológicos hepatocelulares da FE. A segunda diz respeito à explicação etiológica dos mesmos e trata da controvérsia sobre a presença ou não de subs- tâncias indispensáveis para as células hepáticas no sangue portal. A terceira e última relata a demonstração de que essas substâncias existem, quais já foram identificadas, e as hipóteses levantadas para explicar seu modo de ação.

$\mathrm{O}$ efeito mais marcante do desvio do sangue portal no fígado é a atrofia do parênquima. As primeiras observações referentes à diminuição do tamanho do órgão foram feitas em cães por Whipple e Sperry ${ }^{876}$ e Whipple e Hooper 874 no começo do século, Todavia, coube a Mann e à sua escola $471=472$ descrever minuciosamente as alterações macroscópicas do fígado de cães com $\mathrm{FE}$. Verificaram redução de $50 \%$ no peso do ôrgão e aparecimento de um aspecto macroscópico por eles considerado característico, seis a dez semanas depois da cirurgia. Observaram diminuição do tan manho, palidez e manchas amarelas es. parsas na superfície externa, sem alteração da forma. Essas modificações foram confirmadas em galgos, notando-se, em seis semanas, ređução de $60 \%$ do peso inicial do órgão ${ }^{117}$.

Merecem destaque, contudo, as observações de Rous e Larimore publicadas em 1920 pelo caráter pioneiro em relacionar o sangue portal com o trofismo das
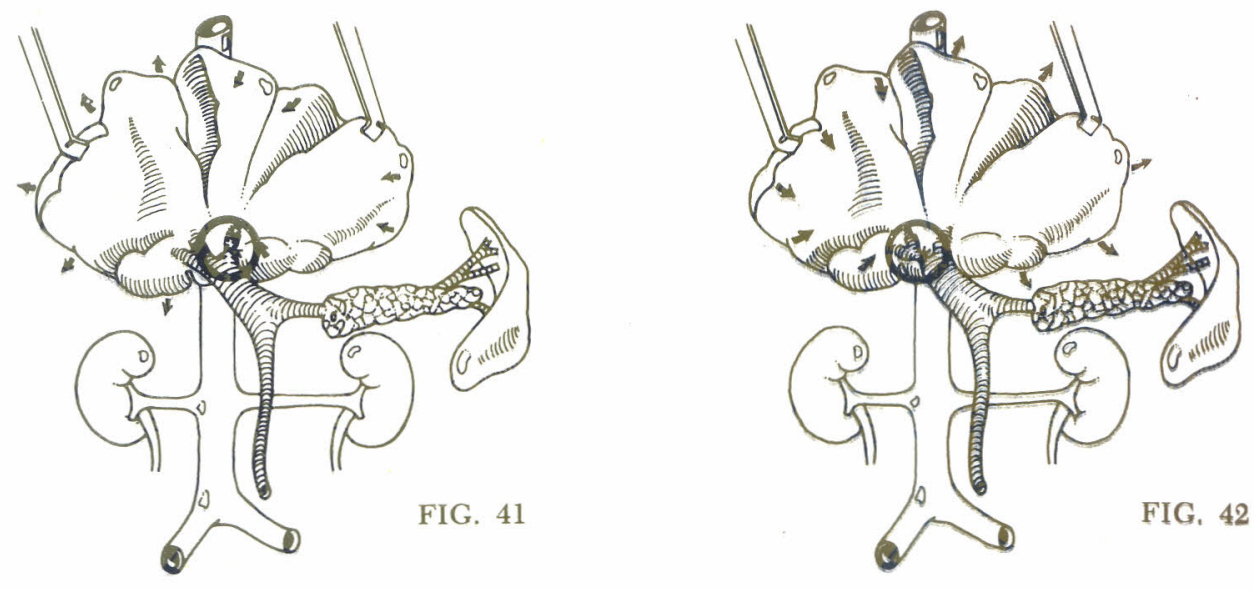
células hepáticas ${ }^{666}$. Em cães e coelhos com ligadura de alguns ramos da veia porta (Figs. 41-42), referiram atrofia do parênquima deles dependente e hipertrofia do restante, "que recebia sangue portal em excesso". Microscopicamente, descreveram diminuição do tamanho dos hepatócitos associada à hiperplasia das células de Kupffer. Esses resultados foram confirmados cinqüenta anos mais tarde por Ozawa e col. ${ }^{567}$. Em modelos idênticos, a partir do quarto dia da ligadura venosa segmentar, verificaram aumento de $30 \%$ no peso total do fígado, com inversẫo das percentagens ponderais relativas aos dois lobos. Assim, o lobo parcialmente isquêmico, representando $60 \%$ da massa hepática antes da cirurgia, reduziu-se para $40 \%$. O restante apresentou a hipertrofia vicariante responsável pelo aumento global.

Em ratos (Fig. 43), o peso do fígado também diminui, embora com maior intensidade nos períodos iniciais de pósoperatório. $\mathrm{O}$ peso médio pré-operatório de $8,93 \mathrm{~g}$ passou rapidamente para $5,33 \mathrm{~g}$ e depois de igual período atingiu $4,34 \mathrm{~g}$, correspondendo a $46 \%$ dos controles ${ }^{252}$. Essa redução se aproxima da referida em outras experiências, nas quais, em trinta dias, o peso médio do fígado baixou de $5,2 \mathrm{~g}$ para $3,5 \mathrm{~g}{ }^{251}$.

$\mathrm{O}$ achado microscópico mais freqüente foi esteatose mais ou menos intensa 295-298-471-472. A análise de biopsias seriadas evidenciou, em cães, que o depósito de gordura ocorre inicialmente no centro dolóbulo ${ }^{419}$ eque ao redor do trigésimo dia interessa todo o parênquima. Além disso, a maioria dos autores refere decréscimo do glicogênio depositado nas células hepáticas ${ }^{734-768}$. A taxa de $31,3 \mathrm{mg} / \mathrm{g}$ baixou para $15,2 \mathrm{mg} / \mathrm{g}$ de tecido hepático à custa da fração solúvel em ácido tricloracético ${ }^{713}$. Outros referem redução de $70 \%$ desta fração do carboidrato ${ }^{768}$. Paralelamente, notou-se aumento nos depósitos de ferro das células de Kupffer ${ }^{117}$, mais marcante na zona centro-lobular ${ }^{669}$. A dosagem em

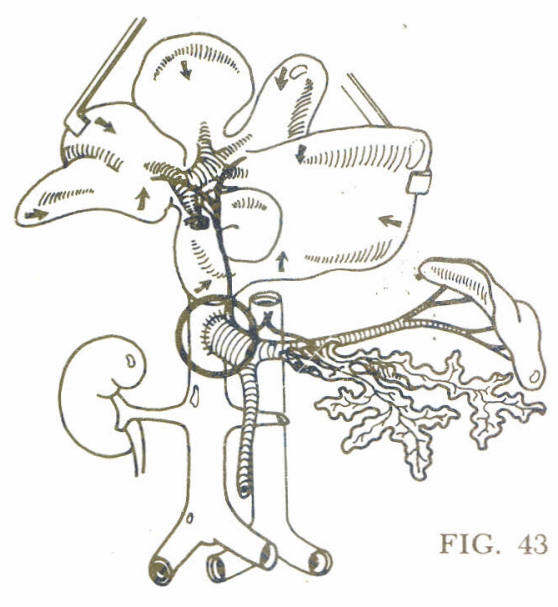

homogenato de fígado demonstrou acréscimo pós-operatório da ordem de $62,3 \%$ 201. Evidenciou-se também que o ferro "depositado não estava unido ao grupo heme e que seu aumento não decorria de maior absorção intestinal ${ }^{200}$. Além disso, Goffi e col. ${ }^{295}$ descreveram redução no conteúdo de ácido fólico, ácido nicotínico e biotina no fígado de cães com $\mathrm{FE}$.

Rubin e col. 669 analisaram, com microscopia ótica e eletrônica, os efeitos morfológicos da $\mathrm{FE}$ em fígado de ratos e, com auto-radiografia, as alterações no seu conteúdo em ADN. Sacrificando animais, respectivamente após trinta, sessenta, noventa e 120 dias da operação, obtiveram dados sobre a evolução desses parâmetros. À microscopia ótica, não observaram alterações a não ser depósito de ferro não muito intenso na zona centrolobular. Independentemente da época analisada, notaram aumento do ADN evidenciado pela impregnação das chapas auto-radiográficas que atingiu intensidade três a quatro vezes maior do que nas controles. Interpretaram este achado como sinal indireto de lesões hepatocelulares não visíveis à microscopia ótica, suficientes para determinar a morte de células em velocidade constante durante o período estudado. Do ponto de vista 
ultra-estrutural, verificaram variação na densidade eletrônica, aparecimento de vacúolos citoplasmáticos de 0,5 a $2 \mu$ de diâmetro. Continham material osmiofílico interpretados como de causa provavelmente anóxica. Além disso, descreveram modificações no retículo endoplasmático de origem possivelmente nutricional e aumento no número de mitocôndrias atribuído a causas inespecíficas.

Em 1972, Ossenberg e col. ${ }^{561}$, também em ratos com $\mathrm{FE}$, referiram diminuição considerável dos níveis do citocromo P450 das células hepáticas.

À medida que se tornaram conhecidos os efeitos morfológicos causados pelo desvio do sangue portal, estabeleceu-se controvérsia para explicar sua etiologia. Surgiram defensores da teoria "qualitativa" e da "quantitativa".

A primeira, enunciada por Rous e Larimore em $1920^{666}$, confere ao sangue portal uma "qualidade" singular por conter fatores indispensáveis ao trofismo das células hepáticas. Essas idéias foram apoiadas, inicialmente, pela escola de Mann ${ }^{471-472}$ que interpretava os efeitos morfológicos como conseqüentes a um estado de carência causado pela falta daqueles elementos.

- A teoria "quantitativa" enunciada por Grindlay e Bollman em 1952316, ao contrário da precedente, atribui os efeitos observados à simples diminuição do fluxo hepático total que a FE determina. Nega assim qualquer "qualidade" especial ao sangue proveniente do território esplênico-pancreático-mesentérico. Este ponto de vista foi substanciado com a publicação de Child III e col. em 1953130. Descreveram, em cães, um modelo com transposição porto-cava total, a partir de então denominado "modelo de Child" (Fig. 24). Nestes animais o sangue portal desviado é substituído por igual volume de sangue proveniente da veia cava. Cria-se assim uma condição hemodinâmica na qual o fluxo hepático total permanece inalterado ${ }^{773}$, mas cons- tituído apenas por sangue sistêmico. Esse modelo é muito útil, uma vez que a diferença mais importante entre estes animais e os controles é a "qualidade" do sangue que chega ao fígado. Se no sangue portal existissem, efetivamente, substâncias indispensáveis para o fígado, os efeitos verificados nos animais com FE deveriam ocorrer também no modelo de Child. O modelo foi usado por Child III e col. ${ }^{130}$ que o descreveram para estudar a influência do sangue portal não no trofismo das células hepáticas, mas unicamente na capacidade de regeneração do fígado. Os resultados despertaram muito interesse pela semelhança fisiopatológica entre o modelo e as condições hemodinâmicas dos pacientes submetidos a uma APC. Realmente, nas duas eventualidades, o sangue portal desviado é substituído por sangue sistêmico. Provém da veia cava e o substitui em igual volume na transposição total ${ }^{773}$. Provém da artéria hepática e o substitui parcialmente na APC ${ }^{603}$.

Devido à semelhança hemodinâmica, os cirurgiões partidários da APC extrapolaram para toda a biologia das células hepáticas a falta de efeitos na regeneração descrita por Child III e col. ${ }^{130}$. Porém, não se justifica esta generalização utilizada como argumento a favor da FE. Em outros laboratórios, o emprego do modelo de Child demonstrou que a substituição do sangue portal por sangue sistêmico não era capaz de evitar uma série de outros efeitos nas células hepáticas ${ }^{765}$.

Em 1957, a extrapolação dos resultados de Child foi estimulada pelas pesquisas de Silen e col. ${ }^{734}$. Compararam cães com FE contra outros com transposição porto-cava total. Demonstraram que a substituição do sangue portal por sangue sistêmico evitava a perda de peso, a atrofia do parênquima hepático, a diminuição de glicogênio e a esteatose hepatocelular verificadas nos portadores de FE.

Mais tarde, em 1967, Fisher e col. ${ }^{251}$, pretendendo também negar a teoria 

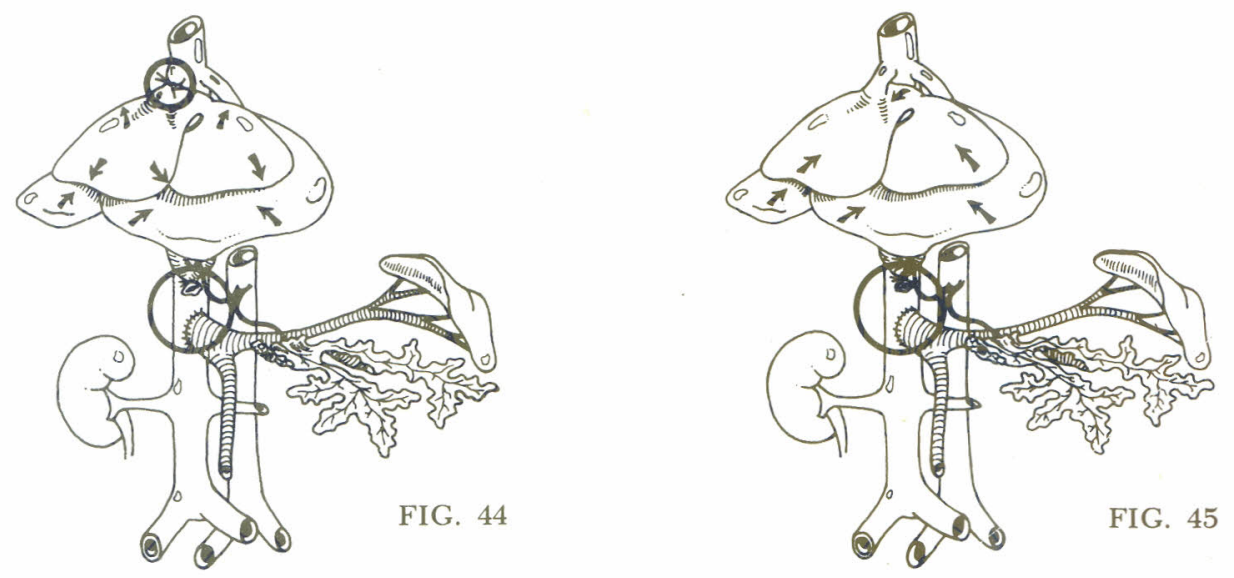

“qualitativa”, realizaram constrição da veia supra-hepática do lobo médio em ratos com FE (Fig. 44). Observaram que a estase sinusoidal protegia o lobo correspondente da atrofia, que ocorreu no restante do parênquima com drenagem supra-hepática normal (Fig. 45). Em ratos normais ou com FE, o lobo médio representou $30 \%$ do peso total do fígado. Em ratos com $\mathrm{FE}$ e constrição suprahepática daquele tipo, a mesma porção anatômica correspondeu a $47 \%$ do peso total do órgão. Além disso, a hipertensão sinusoidal do lobo médio diminuiu a redução do peso total. Nos controles foi de 10,5 g em média, reduzindo-se para 5,2 g nos animais com FE. Já naqueles com hipertensão sinusoidal do lobo médio, a redução foi menor (6,8 g). Estudando o conteúdo de água e proteínas do lobo congesto, demonstraram que a preservação do seu peso não era conseqüente a edema celular, mas à preservação real da sua estrutura. Concluíram, então, que a atrofia do fígado, causada pela FE, não decorria da falta de componentes do sangue portal, mas sim de outros fatores entre os quais incluíram a pressão sinusoidal.

A teoria "quantitativa", porém, foi fortemente questionada pelas informações obtidas em modelos com transplante auxiliar de fígado, que podem ser assim resumidas:

Em cães, realizaram-se transplantes heterotópicos de fígado desprovidos de sangue portal. Os enxertos eram irrigados com sangue sistêmico proveniente da aorta e da veia cava do receptor (Fig. 46). Apresentaram marcante atrofia 45 dias após a cirurgia ${ }^{767}$. Interpretou-se este comportamento como prova de que no sangue portal existiam fatores indispensáveis para o trofismo das células hepáticas possivelmente clareados numa única passagem pelo fígado autóctone.

Vários autores corroboraram esta interpretação em modelos' semelhantes mas com fatores hepatotróficos desviados para o transplante. Em alguns, obteve-se a passagem inicial pelo enxerto através de FE no receptor (Fig. 47) $329-819$. Em outros, pela remoção do fígado autóctone uma semana após o transplante (Fig. $48)^{805}$. Em outro grupo ainda, o fornecimento de fatores hepatotróficos para o transplante foi garantido pela ligadura do colédoco hospedeiro ${ }^{826}$ (Fig. 49). Pretendia-se reduzir o clareamento dos fatores na sua passagem pelo fígado autóctone. Em todas estas variantes notouse um comportamento oposto ao obser- 

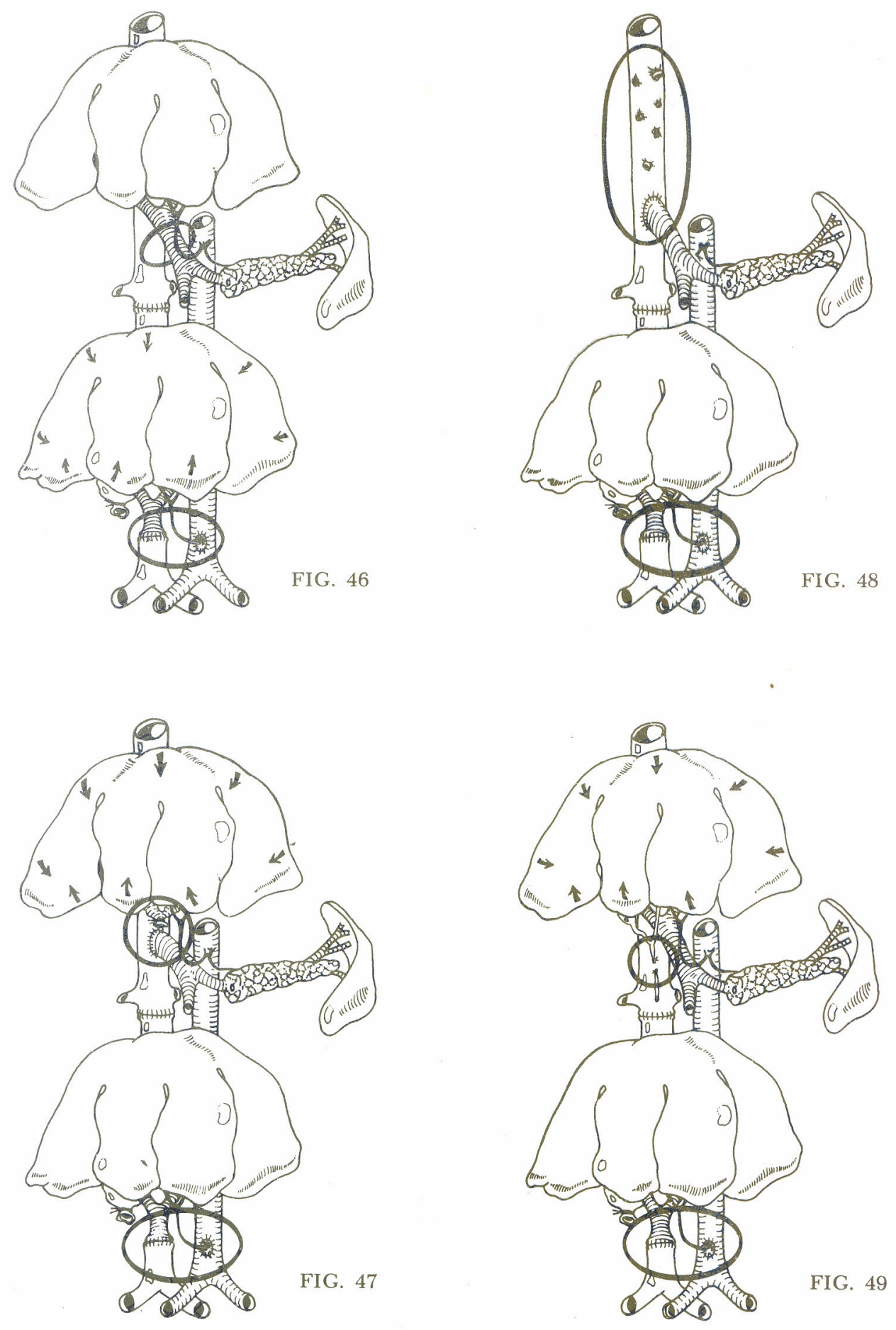

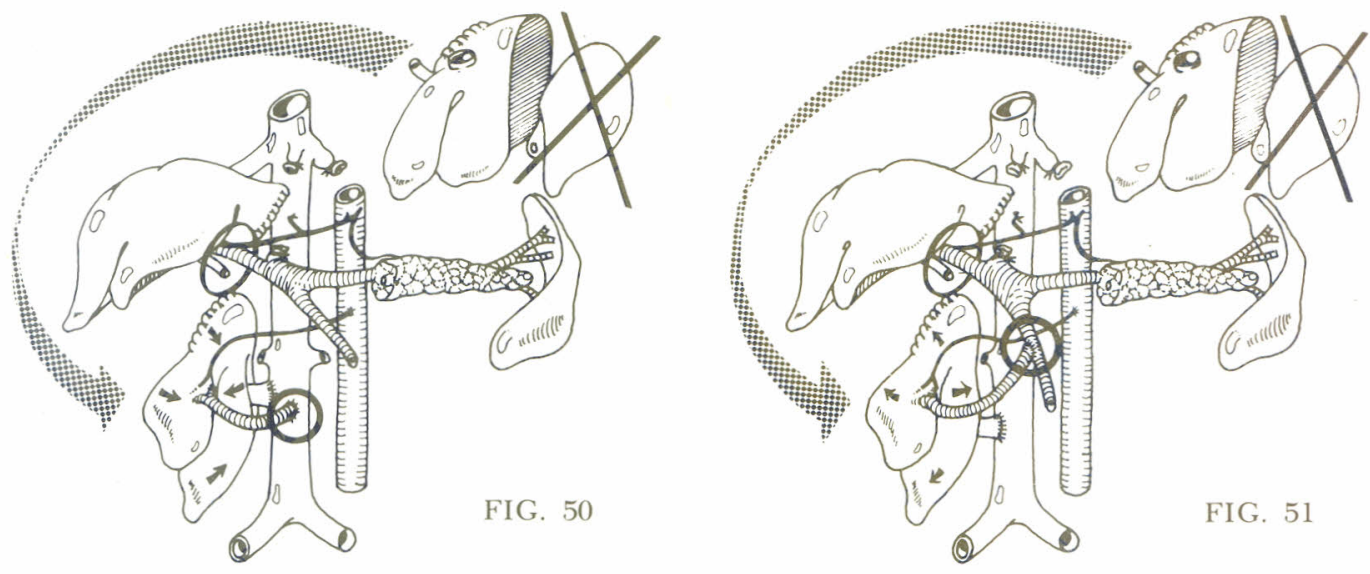

vado nos modelos originais. $\mathrm{O}$ processo de atrofia ocorreu no órgão do hospedeiro, preservando o transplante.

Esses resultados, no entanto, mereceram críticas procedentes. Citam-se causas de erro representadas por fenômenos de rejeição, imunossupressão e agressão isquêmica, além da diferença entre o fluxo sanguíneo total do fígado autóctone e do enxerto. Essas limitações metodológicas suscitaram dúvidas sobre a etiologia das alterações tróficas, sugerindo que poderiam ser conseqüentes a fatores não dependentes do sangue portal. Contudo, é importante ressaltar que as lesões hepatocelulares dos transplantes heterotópicos desprovidos de sangue portal foram em tudo semelhantes às descritas emcães com FEpor Manne col.471-472 e confirmadas mais tarde por outros autores ${ }^{419}$.

Para evitar aquelas causas de erro, os defensores da teoria "qualitativa" criaram outros modelos. Assim, os efeitos da falta de sangue portal foram estudados em transplantes isentos de fenômenos de rejeição e imunossupressão. Compararam-se modelos com sangue portal dirigido para o transplante ou mantido para o fígado autóctone. As duas modalidades foram estudadas em autotransplantes parciais de fígado na fossa ilíaca di- reita de cães ${ }^{604}$ (Figs. 50-51), autotransplantes parciais de fígado na região cervical de cães ${ }^{728}$ (Figs. 52-53) e isotransplantes de fígado na fossa ilíaca de ratos $^{428}$ (Figs. 54-55).

Em todos esses modelos obteve-se confirmação da dependência entre o trofismo hepatocelular e o aporte direto de sangue portal. Porém, não foram evitados os inconvenientes da agressão isquêmica, nem da diferença entre os fluxos do parênquima remanescente autóctone e do transplante.

Em 1967, Marchioro e col.477 contornaram tais dificuldades descrevendo um modelo muito engenhoso em cães, a partir daí designado como "modelo Marchioro". Metade do fígado recebia sangue portal, enquanto à outra chegava apenas sangue sistêmico através de uma transposição porto-cava parcial (Fig. 56). Estudaram a influência do sangue portal nas células hepáticas alternando os lobos por ele perfundidos (Fig. 57). Estas condições são mais exatas, uma vez que cada animal representa controle para si próprio. Notaram atrofia do parênquima perfundido por sangue sistêmico e hipertrofia daquele que recebia sangue portal. Anos mais tarde, Starzl e col. ${ }^{765}$ valorizaram esses resultados demonstrando, adi- 

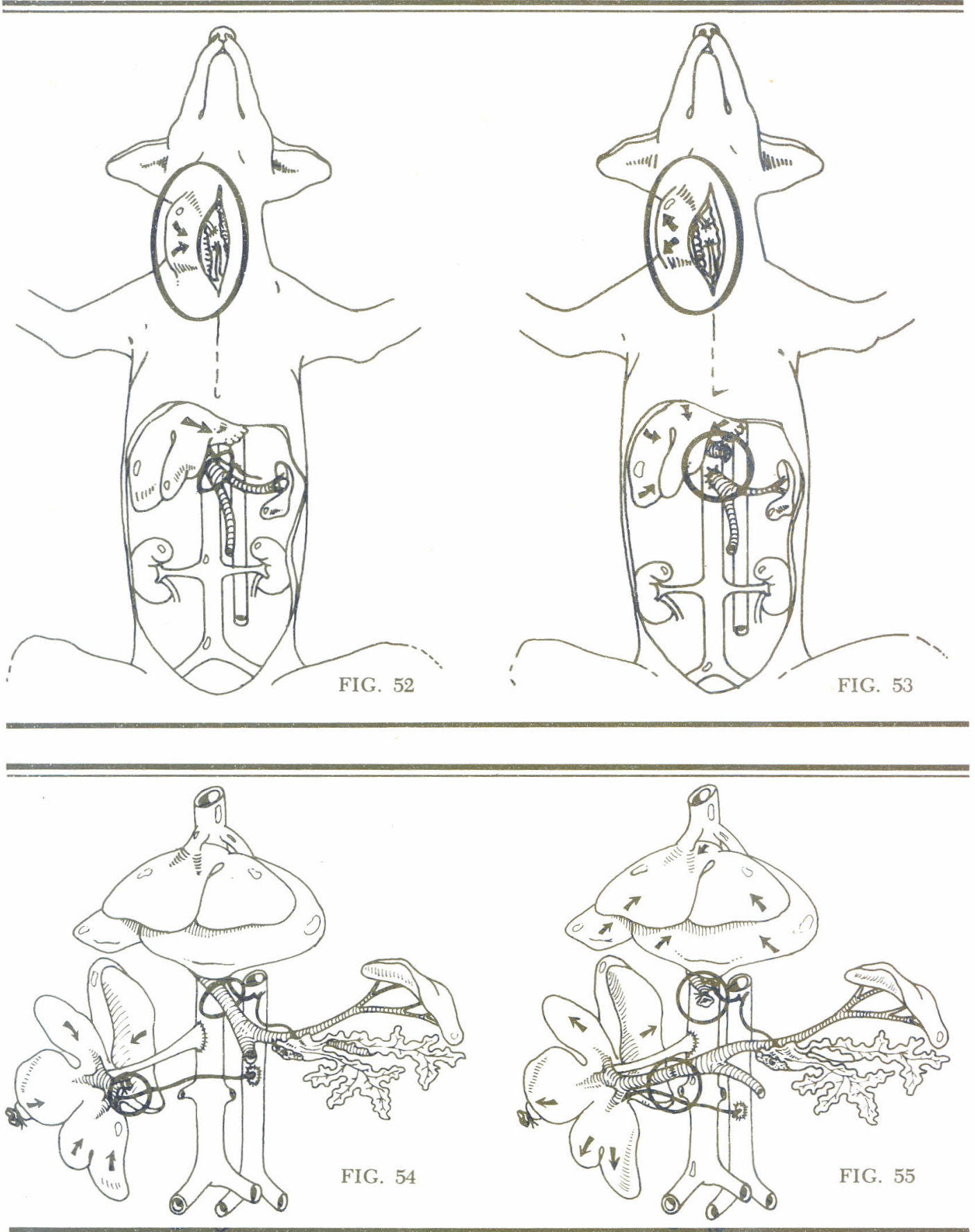

cionalmente, redução dos depósitos de glicogênio no parênquima atrofiado e aumento naquele perfundido com sangue portal.
A exatidão da teoria 'qu litativa' foi assim confirmada. Surgiu, então, interesse em identificar os fatores hepatotró . ficos e seu mecanismo de ação. Estas 

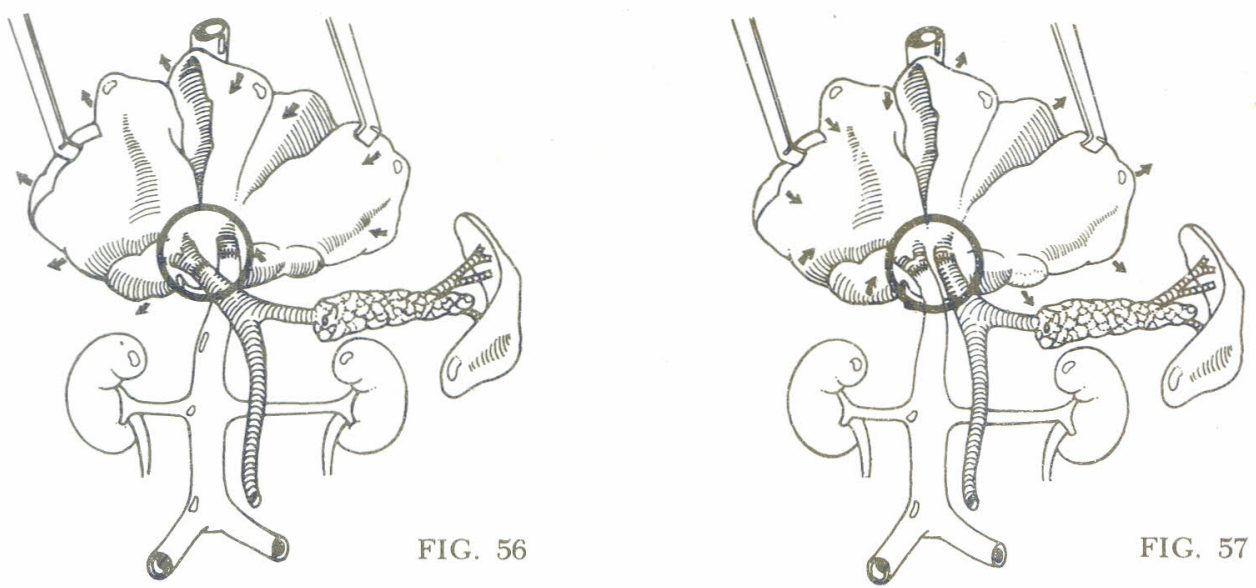

questões foram esclarecidas por vários autores em modelos com transposição porta cava seletiva. $O$ sangue prove. niente de diferentes territórios do sistema porta foi dirigido, alternativamente, para o lobo direito ou esquerdo. Assim, em 1969, Pouyet e col. ${ }^{595}$, usando em cães modelos extremamente elaborados, localizaram a origem dos fatores hepato tróficos do sangue portal. Interpuseram enxertos autólogos de veia jugular, alternativamente, entre o lobo direito ou esquerdo de um lado e as veias mesentéricas superior ou esplênica de outro. Com base na variação de peso, demonstraram que o simples aumento do fluxo não era suficiente para determinar hipertrofia. Tal processo não ocorreu em modelos com fluxo mesentérico dirigido para o lobo direito o que acarreta aumento de $80 \%$ no volume de sangue recebido por esta porção do fígado. Pelo contrário, a diminuição do fluxo portal ocasionou atrofia proporcional à sua redução, desde que não contivesse sangue proveniente do território pancreáticoduodenal. Paralelamente, o aumento do fluxo do sangue desse território determinou hipertrofia proporcional até acrésci mos de $50 \%$. Além disso, c sangue portal procedente dessa região evitou a atrofia em condições de hipofluxo. Decréscimos de até $80 \%$ do débito não causaram perda de peso superior a $6 \%$ no parênquima correspondente. Concluíram que a redução do fluxo portal não causa atrofia hepática, desde que o sangue pancreático persista dirigido ao fígado. Assim, identificaram o pâncreas como sede dos fatores hepatotróficos, ainda que pelos seus estudos não pudessem excluir o duodeno como co-participante.

Essas conclusões pioneiras explicam os resultados publicados quatro anos antes por Jolly e col. ${ }^{390}$. Usaram modelo

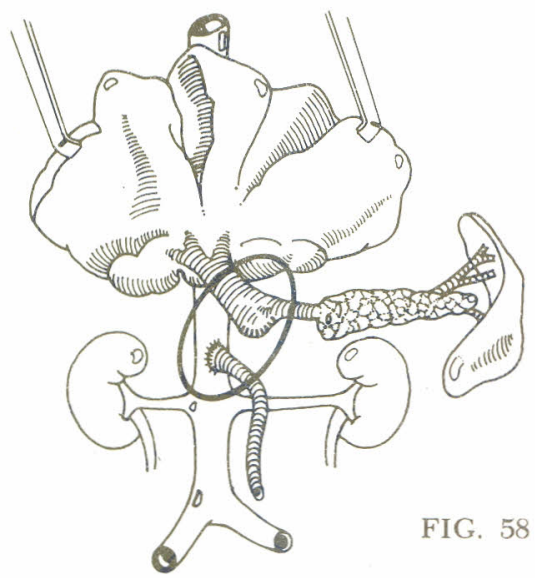


por eles denominado “desvio portal parcial". O sangue intestinal é desviado para a circulação sistêmica através de uma anastomose mesentérico-cava término-lateral. Por sua vez, o sangue espleno-gastro-pancreático é mantido em direção ao fígado (Fig. 58). Verificaram que nove cãès sobreviveram até o fim do período de estudo, sem perda de peso e com preservação macro e microscópica do fígado. Esse comportamento diferiu totalmente do observado em outros dez cães com FE. Apresentaram uma seqüência grave de alterações precedendo a morte por caquexia, dez a dezesseis semanas após a cirurgia.

A origem dos fatores hepatotróficos no território espleno-gastro-pancreático foi confirmada por Ranson e col., em 1971 626. Num primeiro tempo realizaram ligadura do ducto hepático, vagectomia e gastrenteranastomose em cães. Duas semanas depois, completaram o modelo com um transplante homólogo heterotó pico parcial de fígado. O enxerto recebia sangue procedente de dois diferentes territórios do sistema porta. O desempenho funcional e a preservação morfológica foram nitidamente superiores nos enxertos que recebiam sangue do território espleno-gastro-pancreático do que em

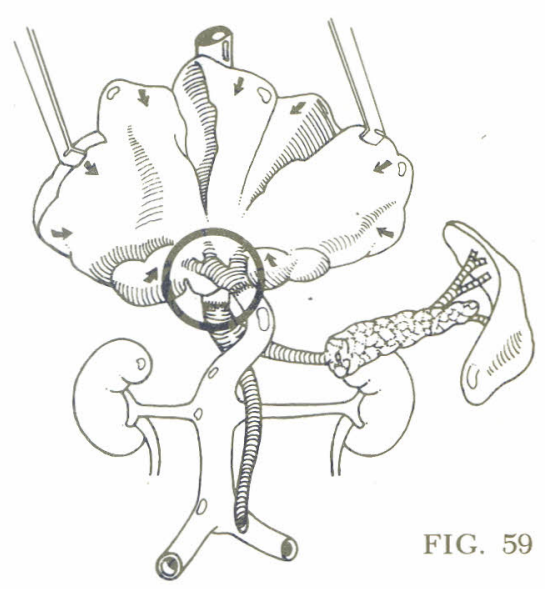

outros semelhantes mas perfundidos somente por sangue mesentérico.

Entretanto, coube a Starzl e col. ${ }^{765}$, em investigação exemplar, localizar definitivamente no pâncreas a origem dos fatores hepatotróficos. Em mais de cem cães com irrigação arterial hepática preservada, compararam os efeitos hepatocelulares determinados pelo desvio do sangue proveniente de diferentes territórios do sistema porta. Utilizaram-se de cães com transposição porto-cava total segundo técnica de Child III 130; com transposição porto-cava parcial, conforme técnica descrita previamente em seu laboratório por Marchioro e col. 477; ou ainda com transposição porto-cava parcial seletiva. Nesta última, de acordo com técnica original, metade do fígado recebe sangue espleno-pancreáticogastroduodenal, enquanto que a outra recebe apenas sangue procedente do intestino. O primeiro é rico em hormônios e pobre em elementos nutritivos. $\mathrm{O}$ segundo apresenta composição inversa. Nos catorze animais operados segundo o modelo de Child, constataram nítida atrofia do fígado (Fig 59). Dois meses após a cirurgia, o órgão pesava cerca de $1,8 \%$ do peso corpóreo, valor claramente menor do verificado nos controles $(2,8 \%)$. A redução ponderal foi concomitante à diminuição no tamanho das células hepáticas. Segundo o critério adotado baixou, em média, de doze para oito unidades. Paralelamente, o conteúdo em glicogênio do parênquima hepático passou de $2,82 \mathrm{mg} / \mathrm{g}$ para $2,10 \mathrm{mg} / \mathrm{g}$. Nos animais operados segundo o modelo de Marchioro, os resultados obtidos confirmaram os referidos previamente pelo grupo. Demonstraram atrofia do parênquima desprovido de fluxo portal e hipertrofia do restante (Figs. 56-57). É interessante notar que o processo hipertró fico, observado no lobo perfundido por todo o sangue portal, ocorreu com intensidade apenas suficiente para compensar a atrofia do outro lobo. De fato, não ocor- 

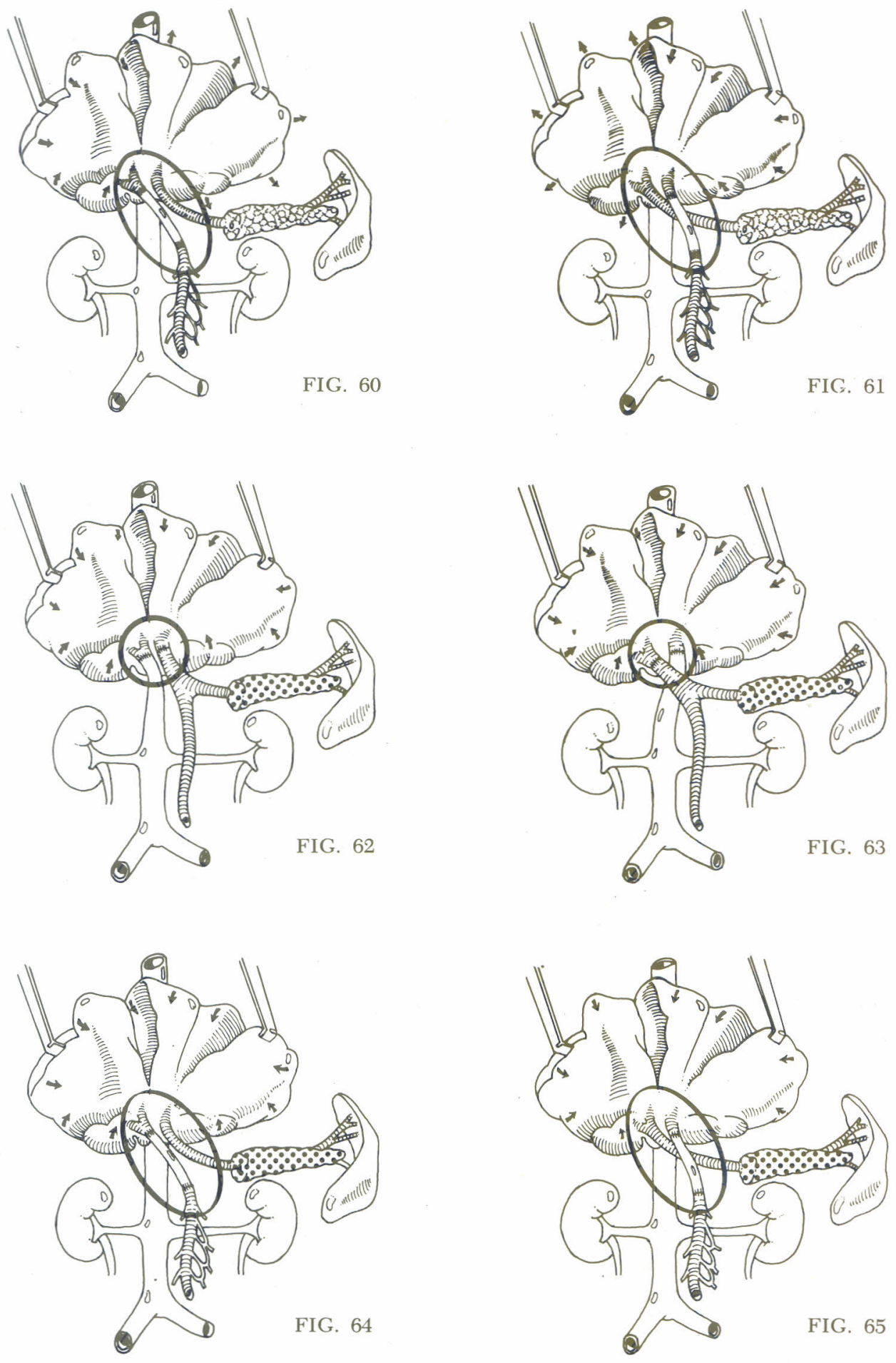
reu variação do peso total do órgão. A transposição porto-cava seletiva demonstrou que os fatores hepatotróficos são produzidos no território pancreáticoesplênico-gastroduodenal (Figs. 60-61).

Uma vez definido o local de origem dos fatores, surgiu interesse em identifi . car o órgão responsável pela sua produção. Os modelos empregados por Pouyet e col. ${ }^{595}$, Jolly e col. ${ }^{390}$, Ranson e col. ${ }^{626}$, Starzl e col. ${ }^{765}$ não permitem localização topográfica precisa. $\mathrm{O}$ sangue que protege o fígado contra os efeitos da FE provém tanto do pâncreas quanto do estômago, duodeno e baço. Contudo, resul tados também recentes sugerem que os fatores hepatotróficos do sangue portal agem através de um mecanismo hormonal e apontam o pâncreas como sede mais provável de sua origem ${ }^{601}$. Esta hipótese foi confirmada por Starzl e col. ${ }^{765}$ nos animais com transposição porto cava parcial seletiva. Verificaram que o tecido hepático perfundido com sangue pancreático-esplênico-gastroduodenal apresentava concentrações mais altas de glucoquinase e mais baixas de ciclo 3' $5^{\prime}$ - adenosina monofosfato. Com base nesses dados, apontaram a insulina e o glucagon como os fatores hepatotróficos cuja ausência causava os efeitos descritos. Consideraram que, em condições normais, a insulina exerce função anabolizante, enquanto que o glucagon desempenha função oposta. Segundo eles, a homeostase das células hepáticas depende da relação normal entre ambos, hipótese recentemente comprovada por Leffert ${ }^{431}$ em cultura de células hepáticas.

A ação anabolizante da insulina é demonstrada claramente em modelos com diabete induzida por aloxane ${ }^{901}$ uma vez que o efeito protetor exercido pelo sangue do território pancreático-esplênico-mesentérico não mais ocorre ${ }^{769}$ (Figs. 62-63-64-65).

A importância da insulina para o trofismo normal das células hepáticas foi confirmada pela contribuição do grupo de Ozawa ${ }^{566-567-568-569}$. Estudaram a ação do hormônio na capacidade fosforilativa das mitocôndrias das células hepáticas. Comprovaram que a insulina, na concen tração com que ocorre no sangue portal, é indispensável para a produção da enérgia necessária à biologia normal dos hepatócitos. A capacidade fosforilativa diminui, na falta completa ou parcial de sangue portal. Observaram depressão evidente abaixo dos níveis necessários para a manutenção morfológica e funcional das células hepáticas. Inversamente, a chegada de sangue portal em excesso determina um processo de hipertrofia, atribuído ao desequilíbrio quantitativo entre insulina disponível e captação hepatocelular. Explicaram, assim, os resultados de Rous e Larimore ${ }^{666}$, que, em 1920, já tinham interpretado a hipertrofia vicariante peloi "sangue portal em excesso".

Starzl e col., em $1975^{769}$, forneceram provas adicionais para a definição do caráter hormonal dos fatores hepatotróficos. Em cães com transposição portocava parcial e seletiva, estudaram o conteúdo total de proteínas, lípides e ADN, calcularam a população de células em mitose e mediram o tamanho das células hepáticas. Usaram os mesmos modelos anteriores, acrescidos ou não de diabete induzida por aloxane ou por pancreatectomia total. Confirmaram os resultados anteriores nos animais não diabéticos. $\mathrm{O}$ parênquima nutrido com sangue pancreático apresentou hipertrofia macro e microscópica, maior número de células em divisão e preservação do glicogênio intracelular em relação ao parênquima do lado oposto. Porém, nos animais com diabete induzida por drogas (Figs. 6263-64-65) ou por ressecção da glândula pancreática (Figs. 66-67-68-69), constataram ausência daquela disparidade. Este comportamento não se alterou pela administração subcutânea de insulina. Não observaram diferença entre os dois mo- 

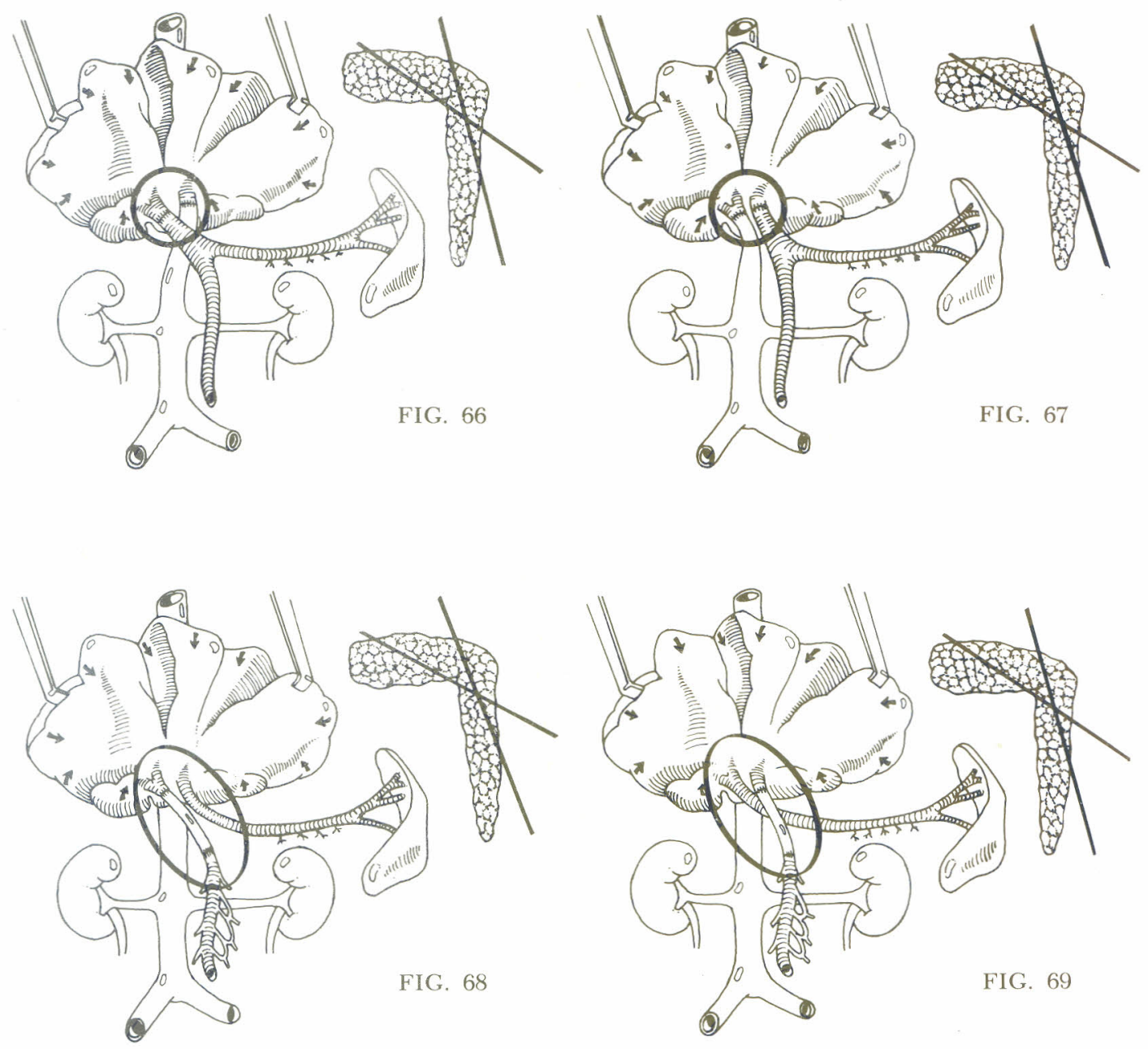

delos diabéticos, a não ser diminuição seletiva dos depósitos hepatocelulares de glicogênio nas experiências com aloxane. Relacionaram este efeito com a persistência do fornecimento de glucagon. Para os outros parâmetros, a oferta ou a falta de glucagon não provocou diferença apreciável. Chamaram a atenção também para o fato de que, nos animais diabéticos, a maior divisão celular ocorreu no parênquima irrigado com sangue intestinal ou sistêmico. Concluíram, desta forma, que a insulina é,realmente,o fator mais importante para o trofismo das células hepáticas. Os efeitos protetores observados em modelos com transposição porto-cava seletiva desapareceram com a retirada do local de produção de insulina.

Estas últimas experiências mostram a importância da insulina através de mecanismos supressivos. Mais recentemente, Starzl e col. ${ }^{771}$ forneceram outro tipo de comprovação. Empregaram modelos com ligadura isolada dos dois ramos da veia porta e APCLL (Fig. 70). 


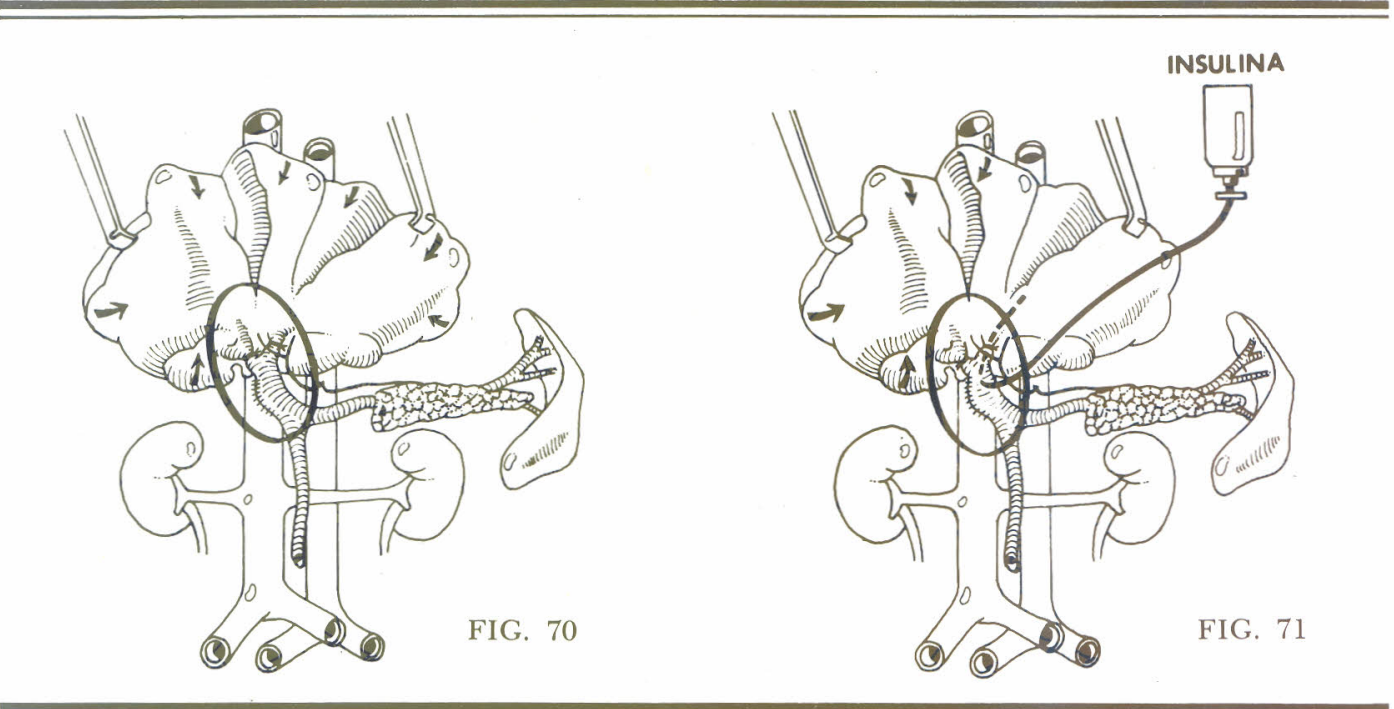

Num dos ramos ligados introduziram um cateter exteriorizado através da pele (Fig. 71). Demonstraram as anormalidades estruturais já referidas no parênquima do lado oposto. Pelo contrário, estes efeitos foram abolidos quase completamente no parênquima cujo ramo da veia porta tinha sido cateterizado. $\mathrm{O}$ efeito protetor foi atribuído à administração de insulina exógena pelo cateter. A persistência das alterações no parênquima controle foi relacionada ao conhecimento anterior de que as células hepáticas removem o hormônio, avidamente, já na sua primeira passagem pelos sinusóides ${ }^{68}$.

A precocidade dos efeitos determinados pela falta de fatores hepatotróficos foi demonstrada por Starzl e col. ${ }^{770}$, em cães, com transposição porto-cava seletiva. As alterações tróficas no parênquima desprovido de sangue pancreático ocorreram entre o terceiro e o quinto dia de pós-operatório com intensidade semelhante às descritas após dois meses deste tipo de cirurgia.

Todavia, os modelos utilizados pelo grupo de Starz1477-765-769-771 e pelo grupo de Ozawa 566-567-568-569 não permitiram pesquisar a ação de outros hormônios que, eventualmente, exerçam também efeitos hepatotróficos. Alguns esclarecimentos foram fornecidos com o advento de técnicas capazes de cultivar "in vitro" células hepáticas numa única camada 66-123. Usando preparados desse tipo, Leffert, em $1974^{431}$, demonstrou que a síntese de ADN por células hepáticas fetais de ratos sofria a ação de vários hormônios adicionados ao meio de cultura. Foi particularmente interessante a verificação de que os efeitos se potencializavam pela interação dos vários hormônios estudados. Assim, a insulina cristalina e a somatomedina purificada exerceram isoladamente, ou em conjunto, nítida ação estimulante. Em contraposição, o hormônio de crescimento e a hidrocortisona, quando administrados isoladamente, não foram capazes de iniciar o processo de síntese de ADN. Se, porém, adicionados à insulina, potencializaram sua ação em até $100 \%$. Hormônios da tireóide não agiram quando aplicados separadamente. O glucagon inibiu a ação estimulante da insulina reduzindo-a em aproximadamente $50 \%$.

Em 1974, Popper ${ }^{592}$ levantou a hipótese de que também a pentagastrina e o complexo colecistocinina-pancreozimina 
exerceriam efeito hepatotrófico, uma vez que estimulavam o crescimento celular no estômago e pâncreas ${ }^{159-488}$. O mesmo autor considera a insulina e o glucagon como fatores antagônicos para células hepáticas cuja ação seria mediada por nucleótidos de cadeia cíclica. Estas observações reforçam opiniões pelas quais os fatores hepatotróficos são representados por várias substâncias com ação interdependente e relacionada com suas concentrações no sangue portal 431-769-770-771.

2
OBSERVAÇÕES CLINICAS

O estudo das conseqüências do desvio do sangue portal no homem é muito difícil. Faltam informações precisas que permitam conclusões semelhantes às obtidas em animais de laboratório. Não encontramos na literatura referências à APC em indivíduos com fígado normal, a não ser associada a outros tipos de cirurgia. A quase totalidade das APC foi realizada em portadores de moléstias hepáticas causadoras de hipertensão portal. A maioria apresentava moléstia de evolução progressiva como as cirroses micro ou macronodulares (Fig. 72). As alterações anatomopatológicas após a cirurgia podem ser atribuídas tanto à evolução natural da moléstia quanto ao desvio do sangue portal. Por outro lado, são escassos os casos operados com moléstias hepáticas não evolutivas e documentação suficiente. A limitação decorre da raridade das afecções, como no caso das glicogenoses $^{772}$ e da hiperlipemia ${ }^{764}$ ou da falta de seguimento suficiente, como no caso da esquistossomose (cap. II).

$\mathrm{Na}$ revisão deste tópico serão analisados, inicialmente, os poucos casos com fígado normal submetidos também à ressecção da cabeça do pâncreas; depois, os casos com lesão hepática de caráter aparentemente não evolutivo e, finalmente, os cirróticos.

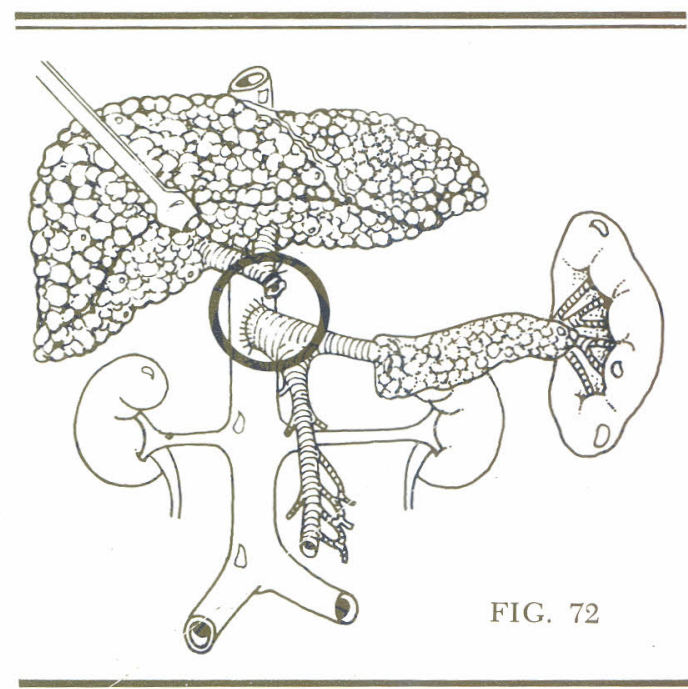

Como citado anteriormente, não encontramos referências à APC em indivíduos com fígado normal. As que mais se aproximam desta situação dizem respeito a quatro pacientes operados por carcinoma da cabeça do pâncreas. A extirpação do tumor exigiu ressecção do segmento retro-pancreático da veia porta e anastomose mesentérico-cava términolateral (Fig. 73) ${ }^{358-493}$. Nos pacientes se-

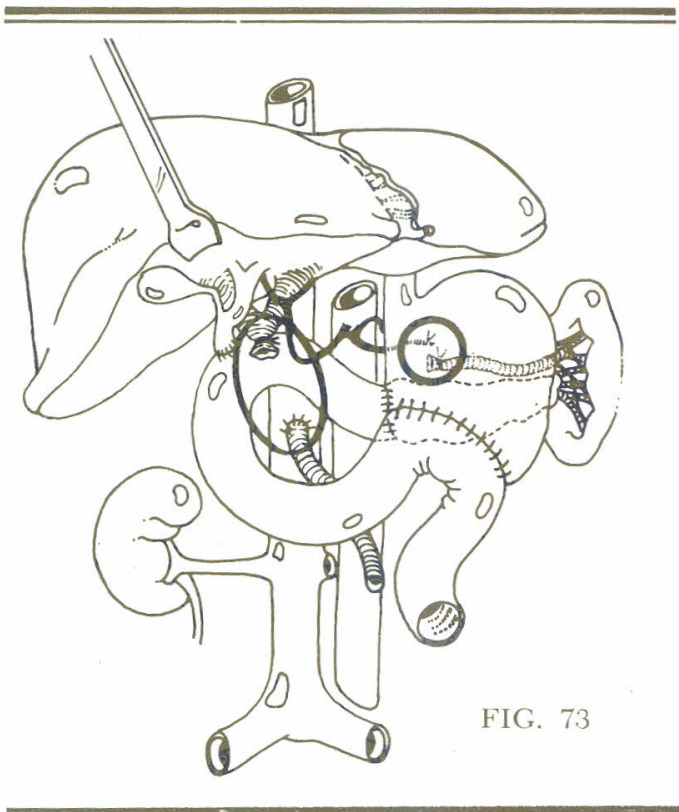


guidos até o óbito, respectivamente 22 , oito e três meseś após o desvio do sangue portal, a necropsia revelou atrofia e intensa esteatose do fígado. Durante a cirurgia o órgão mostrara-se macroscopicamente normal. A interpretação das alterações é dificultada pela importância demonstrada recentemente dos hormônios pancreáticos para o trofismo das células hepáticas ${ }^{765}$. Torna-se difícil porém separar, nestes casos, a contribuição etiológica do desvio do sangue portal e da ressecção pancreática.

Outras informações foram obtidas em pacientes com doenças hepáticas de depósito, destacando-se as referidas por Starzl e col. ${ }^{772} \mathrm{em}$ portadores de glicogenose tipo I, III e VI. Estudaram sete casos próprios e seis de outros autores. Baseados em resultados experimentais, indicaram a APC para reduzir a hepatomegalia 768. Pretendiam aumentar a oferta de glicose aos tecidos periféricos e reduzir os depósitos hepatocelulares de glicogênio. Conseguiram diminuir o tamanho do fígado nas glicogenoses tipo I e VI. Entretanto, biopsias consecutivas demonstraram alteração anatomopatológica imprevista. De fato, a redução do fígado deveu-se a atrofia das células hepáticas que ocorreu com intensidade capaz de compensar um depósito de gordura adicional.

Mais tarde, o mesmo grupo indicou esse tratamento cirúrgico para um caso portador de hiperlipoproteinemia refratária às medidas terapêuticas habituais 764. Fundamentaram-se na visível redução de todos os componentes lipídicos do plasma nos dois pacientes com glicogenose tipo I submetidos à APC. Também neste caso, a comparação das biopsias hepáticas realizadas antes e 168 dias depois da operação mostrou nítida atrofia celular e aumento de seus depósitos de gordura. O estudo pela microscopia eletrônica evidenciou diminuição do retículo endoplasmático, que na biopsia pós-operatória apareceu apenas como fragmentos isolados. Além disso, a análise morfológica demonstrou que a área correspondente a essa organela reduziuse para $1 / 3$ da verificada no préoperatório.

Esses resultados facilitaram a interpretação das observações feitas anteriormente entre nós, em EHE, por Speranzini, em $1971^{762}$. Analisou o aspecto da vascularização arterial do fígado através de cateterismo seletivo em 28 pacientes. Destes, dezenove apresentaram desvio

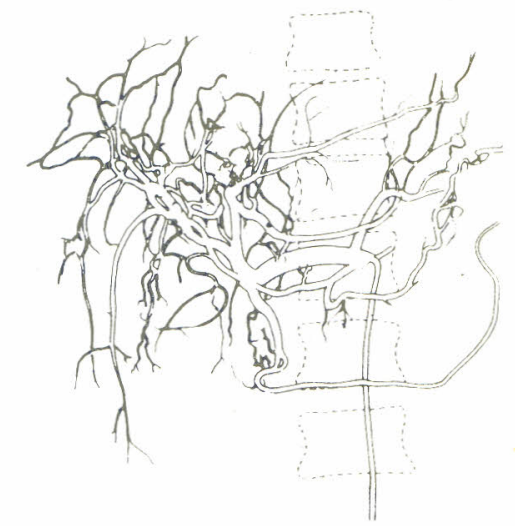

FIG. 74 - Representaçāo esquemática da arteriografia hepática tipo I (copiada de Speranzini 762)

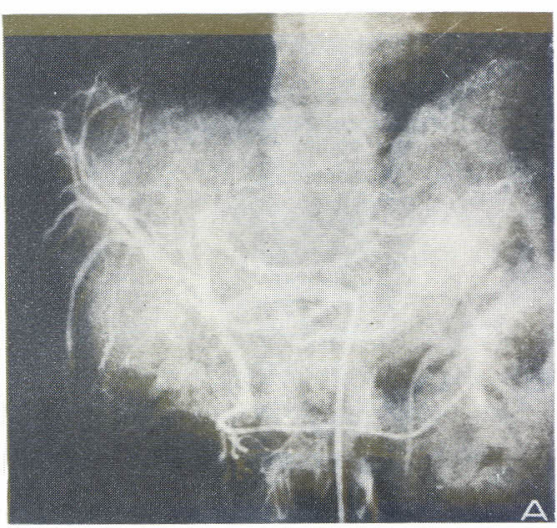

FIG. 75 - Arteriografia hepática tipo I (copiada de Speranzini ${ }^{762}$ ). 


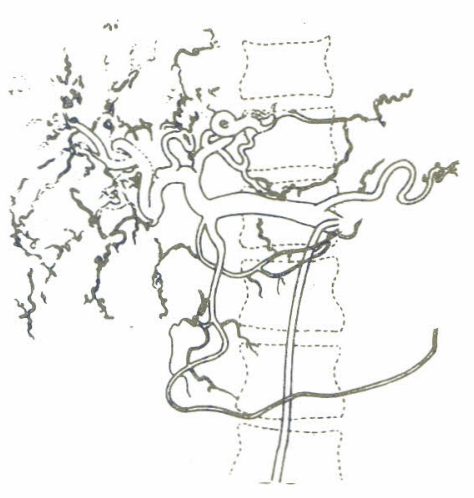

FIG. 76 - Representação esquemática da arteriografia hepática tipo II (copiada de Speranzini 762 ).

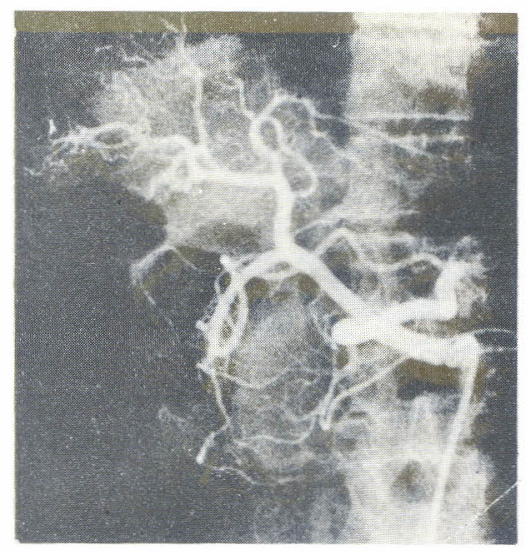

FIG. 77 - Arteriografia hepática tipo II (copiada de Speranzini ${ }^{762}$ ). do sangue portal por meio de uma AER ou através de circulação colateral conseqüente à trombose da veia porta. Classificou em dois tipos fundamentais a vascularização arterial conforme os caracteres das ramificações. No tipo I (Figs. 74-75), as ramificações de primeira e segunda ordem mostravam-se numerosas, calibrosas, com trajeto retilíneo ou levemente sinuoso e divisão ordenada. Mostravam o quadro vascular intra-hepático, característico da esquistossomose hepatesplênica ${ }^{17}$. Ao contrário, no tipo II (Figs. 76-77) as ramificações eram mais escassas, com trajeto acentuadamente sinuoso. Apresentavam dilatações e constrições alternadas, dando a impressão de contas de rosário, como descrito nas fases avançadas da cirrose hepática ${ }^{597}$. Relacionou então, em cada caso, o tipo de vascularização com o fluxo portal. Móstrou relação estatisticamente significante entre fluxo portal preservado e vascularização tipo I. Nos casos com fluxo portal desviado, predominaram intensas alterações vasculares do tipo II. Seus resultados sugeriram que o desvio portal altera a vascularização arterial com o decorrer do tempo. Nos oito casos com AER pérvia, operados há menos de um ano, observou vascularização do tipo I em quatro e do tipo II nos restantes. Nos nove casos operados há mais de um ano verificou vascularização do tipo I em apenas um e do tipo II nos oito restantes. Baseado nestes dados e em outros da literatura ${ }^{537}$, considerou a modificação da vascularização intra-hepática como demonstração de um processo de atrofia do fígado. Relacionou o fenômeno com a falta de fluxo hepático portal.

Por fim, devem ser mencionadas as observações referidas por Mikkelsen e col. ${ }^{502}$. Estudaram 36 casos separados retrospectivamente entre os quatrocentos operados nos últimos dezoito anos para tratamento da hipertensão portal. Selecionaram os casos cujas biopsias cirúrgicas mostravam apenas lesões hepáticas mínimas, representadas por discreta fibrose nos espaços porta.

Dos treze pacientes submetidos a uma APC, quatro morreram em insuficiência hepática progressiva. Naqueles que faleceram dois anos após a cirurgia, a necropsia revelou atrofia do fígado com peso entre 700 e $1000 \mathrm{~g}$. Microscopicamente, descreveram aumento da fibrose, que partindo do espaço porta invadia os lóbulos sem delimitar, porém, nódulos de regeneração. Essas alterações pósoperatórias podem ser entendidas como 
mais uma demonstração dos efeitos morfológicos hepatocelulares do desvio do sangue portal. Todavia, seus autores preferiram interpretá-las como resultado do caráter evolutivo de uma nova moléstia, por eles denominada "esclerose hepatopetal". A falta, porém, de observações semelhantes em pacientes não operados e o conhecimento dos dados relatados por Guimarães em 1969 319, em EHE, favorecem a primeira interpretação. Realmente, este autor demonstrou, por meio de uma AER centralizada, que o desvio do sangue portal causou, após um ano, aumento da fibrose hepática em seis de quinze operados.

Mais recentemeñte, Mies e col. 500-613 entre nós documentaram também alterações na rede portal intra e extrahepática de EHE submetidos a derivações portais. Empregaram cinerradiografia e radiografia seriada do sistema porta em pacientes operados entre um mês e dois anos antes. Verificaram nítida redução do diâmetro da árvore portal, como já referido por Speranzini ${ }^{762}$. Além disso, descreveram estagnação intra-hepática, em relação ao aspecto pré-operatório, estudado por esplenoportografia. Merece destaque sua referência à falta destas alterações em pacientes semelhantes submetidos a derivações portais seletivas, nos quais o fluxo portal hepatopetal permanece presente. Segundo os autores, a estagnação precede as outras alterações portais e as do sistema arterial intra-hepático, aparecendo já aos trinta dias de pós-operatório.

Percebe-se assim que no homem, apesar do seu pequeno número, a uniformidade dos dados permite concluir que, como nos animais de laboratório, o desvio do sangue portal provoca atrofia e esteatose das células hepáticas e, provavelmente, aumento da fibrose preexistente.

Leger e col. ${ }^{433}$ são contrários a esse ponto de vista. Em base de observações feitas em pacientes cirróticos, antes e depois da derivação, consideram que a APC não provoca atrofia do parênquima hepático. Mediram a altura de 278 fígados cirróticos antes da cirurgia. Verificaram valores muito semelhantes aos medidos no pós-operatório imediato e tardio de quinze operados. Pesaram os fígados de alguns casos necropsiados antes da cirurgia e de outros falecidos após APC. As médias obtidas não apresentaram diferença estatisticamente significativa. $\mathrm{Na}$ interpretação desses resultados devemse considerar, porém, o aspecto esclerosante da moléstia e o caráter progressivo da fibrose. São capazes de mascarar eventuais alterações nas dimensões e peso do fígado. Não por outras razões os autores que estudam a atrofia hepática em animais empregam citometria ${ }^{765}$. Não confiam apenas nas medidas das dimensões e do peso dos órgãos.

EFEITOS FUNCIONAIS

\section{1 \\ RESULTADOS EXPERIMENTAIS}

As informações são, também, divididas em três partes conforme a seqüência cronológica utilizada no tópico anterior. $\mathrm{Na}$ primeira, descrevem-se as conseqüências funcionais hepatocelulares do desvio. Na segunda, comenta-se a discussão entre os defensores das teorias "qualitativa" e "quantitativa", para explicar a etiologia dos fenômenos observados na etapa anterior. Finalmente, na última referem-se os dados para a compreensão do mecanismo pelo qual os componentes do sangue portal agem na fisiologia das células hepáticas.

O período inicial de contestação à inocuidade da FE contém muito menos informações sobre efeitos funcionais do que sobre alterações morfológicas. Excluindo-se este aspecto, as atenções dirigiram-se muito mais para o estudo do 
quadro neurológico pós-operatório do que para os efeitos referentes à função hepatocelular em si. Esta atenção maior decorreu provavelmente da exuberância dos sintomas da Encefalopatia PortoSistêmica (EPS) e da falta, na época, de conhecimentos sobre a função hepática.

Os poucos dados disponíveis sobre efeitos funcionais focalizam, principalmente, o metabolismo protéico. Assim, Whipple e col. 875 demonstraram, em cães com $\mathrm{FE}$, diminuição na capacidade de normalizar a taxa de proteínas plasmáticas deliberądamente reduzida. $\mathrm{O}$ aproveitamento da dieta hiperprotéica, fornecida após longos períodos de alimentação insuficiente, correspondeu apenas a $10 \%$ do verificado em controles. Em animais com anemia crônica, produzida por sangrias repetidas, observaram redução de até $75 \%$ na utilização de proteínas e do ferro coloidal para reposição da hemoglobina.

Harper e col. ${ }^{334}$ confirmaram, ainda em cães com $\mathrm{FE}$, o efeito do desvio do sangue portal na síntese protéica. Mencionaram que, cerca de 110 dias após a cirurgia, os animais apresentavam acentuada queda na taxa de albumina plasmática, suficiente para causar edema dos membros inferiores. Efeitos semelhantes foram constatados por outros, citando-se diminuição de até 40 na concentração plasmática daquelas proteínas ${ }^{341-734}$.

Paralelamente, Winter e col. ${ }^{883}$ referiram, sempre em cães com $\mathrm{FE}$, decréscimo de $50 \%$ nas taxas séricas de colesterol e ácidos graxos, associados à alteração da curva lipêmica. Pela falta de esteatorréia, concluíram que as alterações eram provocadas por deficiência do metabolismo hepático e não por má absorção.

Goggi e col. ${ }^{299}$ demonstraram, em modelo semelhante, redução estatisticamente significativa das taxas séricas de proteínas totais e albumina em relação aos controles. Esta faltou em animais com $\mathrm{FE}$ e arterialização do coto proximal da veia porta (Fig. 78).

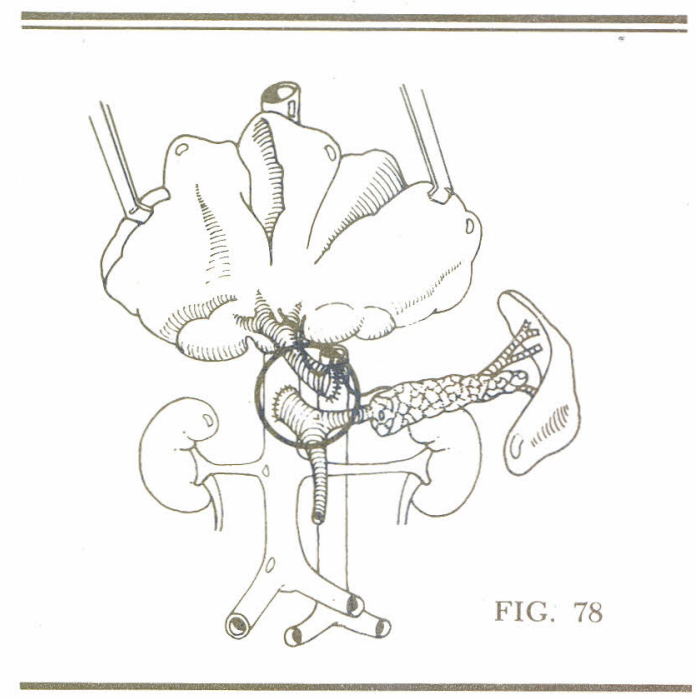

A explicação dos efeitos funcionais do desvio do sangue portal para a circulação sistêmica estimulou duas teorias como para os efeitos morfológicos.

A teoria "quantitativa" justifica os efeitos funcionais apenas pela redução do fluxo hepático total. Baseiam esta interpretação, citando o modelo de Child, no qual o fluxo hepático total permanece inalterado ${ }^{773}$. Referem falta das alterações descritas em animais com FE, como hipoalbuminemia ${ }^{341-734}$, hiperamoniemia e atraso no clareamento de bromosulfaleína (BSP) ${ }^{341-734}$.

$\mathrm{Na}$ discussão destes dados, devem-se considerar alguns aspectos hemodinâmicos. A FE provoca redução no fluxo hepático total. Desta forma, diminui o aporte das substâncias que devem ser metabolizadas pelo fígado por unidade de tempo. Conseqüentemente, as provas funcionais baseadas em clareamentos poderiam estar alteradas sem redução funcional das células hepáticas propriamente ditas. Entretanto, existem dados suficientes para demonstrar sua existência.

De fato, Price e col., em $1967^{604}$, realizaram, em cães, autotransplantes heterotópicos parciais de fígado na cavidade pélvica. Todos os enxertos recebiam 

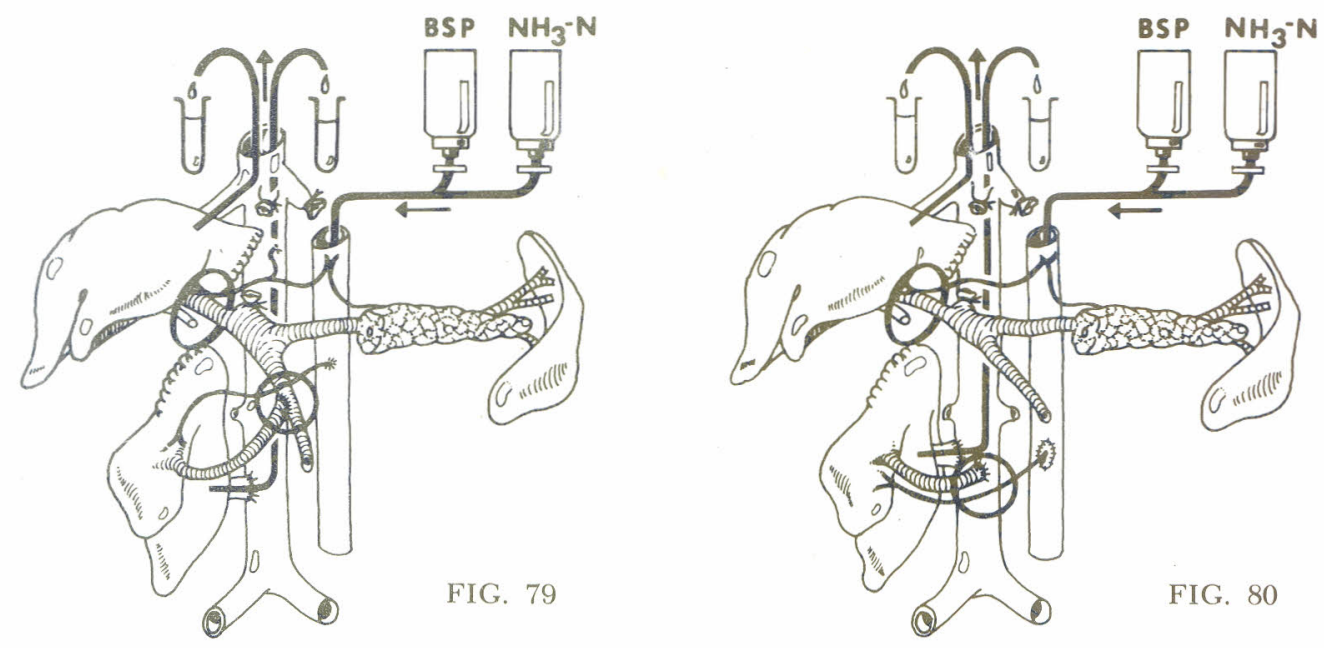

sangue arterial pela artéria hepática. Pela veia porta, chegava sangue venoso proveniente da veia-mesentérica superior num grupo (Fig. 79), e da veia cava inferior no outro (Fig. 80). Colheram amostras para clareamento de amônia e de BSP na veia supra-hepática dos transplàntes. Constataram diminuição na capacidade funcional dos enxertos perfundidos apenas por sangue sistêmico, apesar de os dois grupos receberem fluxo hepático total semelhante. Pelo contrário, os perfundidos também por sangue portal mostraram desempenho comparável ao obtido nos controles. Concluíram que a redução observada nos animais com FE foi devido à falta de elementos indispensáveis ao fígado e presentes no sangue portal.

A contribuição do grupo de Ozawa reforçou consideravelmente a teoria "qualitativa" pela clareza dos seus resultados. Nos últimos cinco anos, analisou o comportamento das mitocôndrias dos hepatócitos perfundidos ou não por sangue portal. Nima primeira etapa, Ozawa e col., em $1971^{567}$, empregaram em coelhos o mesmo modelo, descrito por Rous e Larimore (Fig. 42) cinqüenta anos antes 666. Provocaram dois efeitos hemodinâmicos básicos: interrupção do fluxo portal em $60 \%$ do parênquima hepático e aumento para o restante do fígado, que passava a receber todo o retorno venoso portal. Colheram amostras de tecido hepático, antes e depois da cirurgia. Pesquisaram a fisiologia das mitocôndrias extraídas por ultracentrifugação dos homogenatos correspondentes. A avaliação funcional foi estudada pela capacidade fosforilativa dessas organelas cuja integridade garante o fornecimento de energia para a atividade metabólica das células hepáticas. Verificaram as mesmas

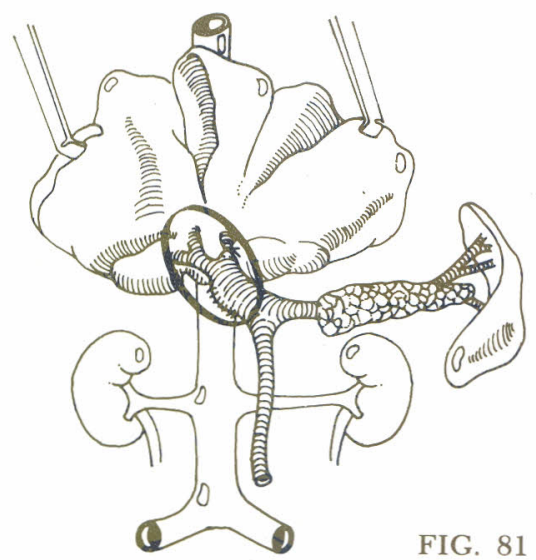

FIG. 81 
alterações tróficas referidas pelos idealizadores do modelo e caracterizadas por atrofia do parênquima desprovido de sangue portal e hipertrofia do restante do parênquima hepático. Além disso, notaram nítida redução da capacidade de fosforilação nas mitocôndrias no tecido desprovido de sangue portal concomitante a aumento no tecido hipertrofiado. Com base em tais anotações, inferiram que o sangue portal continha fatores estimulantes para a função hepatocelular.

No ano seguinte, os mesmos autores 566 acrescentaram uma APCLL ao modelo anterior (Fig. 81) e obtiveram comprovação mais evidente da dependência entre a capacidade de fosforilação das mitocôndrias e o sangue portal. Observaram que os níveis de fosforilação das mitocôndrias no parênquima hipertrofiado não atingiam os previamente constatados no tecido análogo de animais sem derivação. Concluíram que a diminuição do fenômeno era conseqüente ao menor aporte do fator estimulante. De fato, nesse modelo, grande parte do sangue portal é desviada para a circulação sistêmica. O parênquima do lobo com veia porta não ligada recebe menor quantidade do fator estimulante portal. Contudo, a verificação de uma resposta, ainda que menos intensa, permitiu-lhes deduzir que o fator, ainda não identificado, determinava efeitos proporcionais à sua concentração.

Numa etapa seguinte, aqueles autores 568 empregaram, em ratos, modelos semelhantes. Demonstraram que os efeitos já descritos no parênquima com veia porta ligada (Fig. 82) poderiam ser evita-
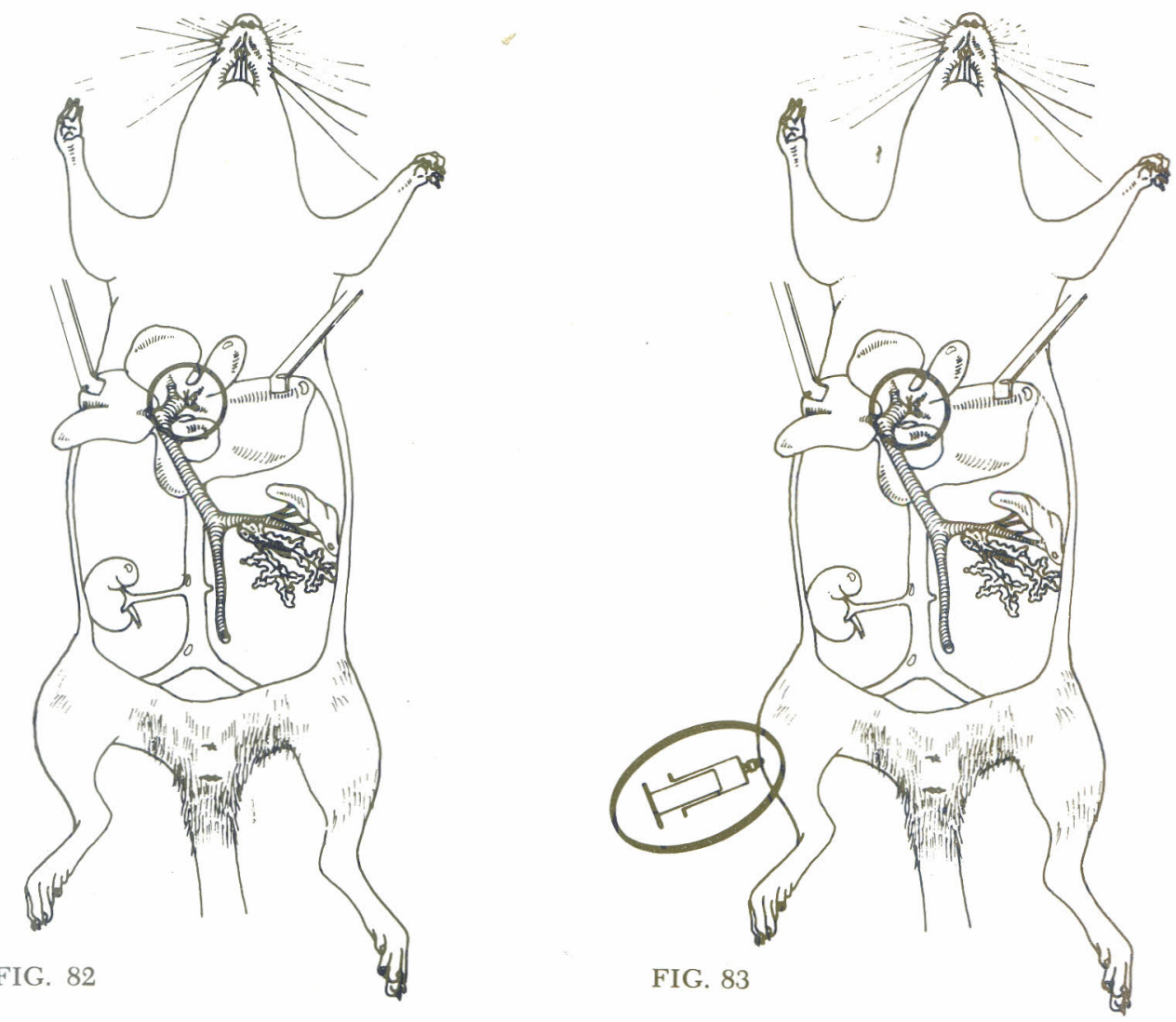
dos pela administração subcutânea de insulina (Fig. 83). Esclareceram, assim, que este hormônio é um dos fatores presentes no sangue portal relacionado com o controle do metabolismo das mitocôndrias.

Finalmente, essa conclusão foi confirmada pelo mesmo grupo ${ }^{569}$ em experiências "in vitro". Novamente em coelhos, ligaram o ramo esquerdo da veia porta. Após 24 horas, retiraram fatias de fígado de $2 \mathrm{~mm}$ de espessura do lobo com veia porta ligada e do lobo com fluxo portal preservado. Incubaram os fragmentos em meio de cultura contendo insulina ( Fig. 84). Compararam os resultados dos homogenatos de parênquima normal com os de parênquima com veia porta ligada.

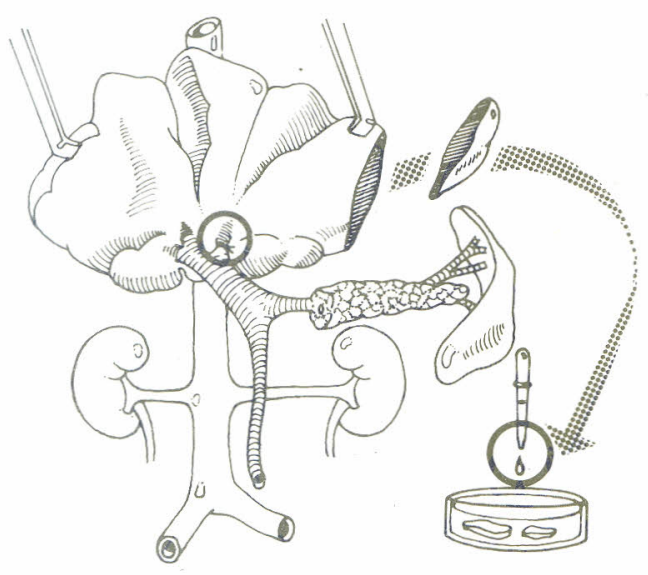

FIG, 84

Além disso, confrontaram amostras colhidas nesses dois territórios antes e depois da incubação. Obtiveram as seguintes informações:

- o metabolismo normal das mitocôndrias e a produção de energia dependem da oferta de uma concentração ótima de insulina;

- para isto, é necessária uma relação normal entre o número de hepatócitos perfundidos e a concentração de insulina no sangue portal;
- o efeito do hormônio parece não depender do aumento da captação de glicose pelas mitocôndrias. A retirada desta substância do meio de incubação não impediu oủ reduziu a resposta;

— os resultados não se repetiram após a substituição da insulina por glucagon no meio de cultura.

Chegaram à conclusão de que a FE reduz o fornecimento de insulina para as mitocôndrias das células hepáticas, provocando diminuição na produção de energia e conseqüentemente na atividade metabólica.

Uma confirmação "in vivo" da importância da insulina para a função das células hepáticas foi obtida por Reaven e col, ${ }^{629}$ em ratos com diabete induzida por aloxane. Constataram relação estatisticamente significativa entre a inibição da síntese proteica e a desorganização ou desaparecimento do retículo endoplasmático, de um lado, e a severidade da diabete induzida de outro. Reforçaram esta contribuição com provas de tipo aditivo. Tanto as alterações ultramicroscópicas quanto a deficiência na capacidade le síntese desapareciam 24 horas depois da administração intraperitoneal e subcutânea de insulina.

Comparação semelhante, também “in vivo", foi obtida por Starzl e col. ${ }^{766}$. Estudaram a síntese de triglicérides e a concentração de colesterol no tecido hepático. Em cães com FE, observaram nítida redução dos dois parâmetros em todo o parênquima hepático. Em modelos com derivação portal super-seletiva, a diminuição só ocorreu no parênquima desprovido de sangue pancreático. Por outro lado, ,este efeito protetor desapareceu em modelos com diabete induzida pelo aloxane.

Desta maneira, pode-se concluir que a queda do desempenho funcional hepático, em animais com FE, é conseqüente a dois efeitos:

- redução na capacidade funcional das células hepáticas devido a forneci- 
mento insuficiente de insulina e, provavelmente, a oucros elementos presentes no sangue portal;

- redução da oferta de substratos ao fígado, nos quais se exerce a maioria das funções metabólicas hepatocelulares.

\section{2}

OBSERVAÇÕES CLINICAS

A maioria das moléstias hepáticas apresenta caráter progressivo, imprevisível e sujeito a influência de muitos fatores. Esta característica causou erros na análise dos efeitos clínicos da APC na função hepática. É impossível atribuir ao desvio as alterações funcionais pósoperatórias observadas em casos isolados. Sua apreciação exata foi alcançada através de estudos prospectivos. Neste método de estudo, um lote homogêneo de pacientes é dividido, por sorteio, em dois grupos. São denominados grupo de estudo e grupo controle. O primeiro é operado e o segundo não. Após análise estatística apropriada, as diferenças verificadas no seguimento dos dois grupos são atribuídas à operação em si. Esta representa o único fenômeno diferente conhecido entre os dois lotes.

A aplicação desse tipo de investigação forneceu dados inéditos sobre os efeitos clínicos da APC. Surgiram dúvidas sobre a conduta adotada até então para o tratamento cirúrgico da hipertensão portal. Dessa maneira, será resumida, inicialmente, a evolução histórica do assim chamado "período das derivações portosistêmicas clássicas" e, depois, o "período da dúvida", iniciado em 1960 com à divulgação dos primeiros resultados de estudos prospectivos.

O período das derivações porto-sistêmicas clássicas corresponde à etapa inicial do tratamento cirúrgico da hipertensão portal. Teve início com a demonstração feita por Allen O. Whipple, de que as varizes de esôfago e sua ruptura eram conseqüentes a um regime de hipertensão no sistema porta ${ }^{872}$. A partir dessa constatação fundamental, o autor e seus colaboradores transformaram a Universidade de Colúmbia num centro de estudo do problema. Dele fizeram parte Arthur Blakemore, Louis M. Rousselot e Jere W. Lord, que muito contribuíram para a era das derivações clássicas. Após constatar recidivas precoces em pacientes submetidos à esplenectomia simples (ES) (Fig. 5) ${ }^{872}$, resolveram descomprimir o sistema hipertenso por meio de uma APC (Fig. 8) obtendo excelentes resultados no controle das hemorragias por varizes de esôfago rotas ${ }^{873}$. Estabeleceu-se, assim, um ambiente de otimismo, levando à impressão de maior e melhor sobrevida para os pacientes operados.

Com̄ o aumento progressivo da casuística, porém, tornou-se claro que esta impressão favorável não era justificada. A mortalidade persistia elevada mesmo após a cirurgia, e a morbidade era muito alta. Incluía queixas e sintomas extremamente sérios, relacionados com um quadro clínico de grave insuficiência hepática. Contudo, a eficácia no controle das recidivas hemorrágicas fez com que muitos autores interpretassem as complicações observadas após APC como decorrentes de outras causas que não a operação propriamente dita. Assim, Blakemore ${ }^{69}$, participando do entusiasmo da época, atribuiu a piora pós-operatória da insuficiência hepática à evolução natural da moléstia. Segundo ele, a deteriorização hepatocelular decorria da sobrevida mais longa dos pacientes submetidos à cirurgia, que permitia à moléstia atingir estágios mais avançados. Já, ao contrário, os não operados faleciam em fases mais precoces em conseqüência de hemorragias digestivas.

Estas considerações difundirarn a indicação da APC na maioria dos centros interessados no assunto. Desse modo, até 1970, estima-se em mais de 10.000 o 
número de cirróticos submetidos a este tipo de desvio do sangue portal nos E.U.A. ${ }^{375}$.

Analisando os trabalhos publicados durante o período de 1950 a 1960, percebe-se que já no fim da década apareceram opiniões que questionavam o valor das derivações porto-sistêmicas clássicas. Entre elas destaca-se a de Nachlas, que em 1958533 levantou dúvidas quanto a sua eficácia em prolongar a vida de pacientes com hemorragias por varizes de esôfago. Segundo ele, o desvio do sangue portal representava uma agressão adicional à função hepática, já alterada pela moléstia causadora da hipertensão portal. Desta forma, considerou que os efeitos benéficos oferecidos pela descomprèssão no controle das hemorragias eram superados pela piora da reserva funcional do fígado.

Logo após, surgiram as primeiras contribuições da escola de W. Dean Warren, que modificou radicalmente o enfoque da questão. Na primeira de uma série de publicações, aqueles autores ${ }^{850}$ estabeleceram relação de causa e efeito entre desvio de sảngue portal e piora da função hepática. Pouco mais tarde, substanciaram estas impressões citando vários casos com excelente reserva funcional hepática antes da cirurgia, que no pósoperatório evoluíram para um quadro de insuficiência hepatocelular progressiva e morte. Ulteriormente demonstraram, ainda por análise retrospectiva, que as conseqüências funcionais eram tanto mais graves quanto maior o fluxo portal hepatopetal pré-operatório ${ }^{851}$.

Estava, assim, definitivamente aberto para discussão o problema dos efeitos funcionais determinados pelo desvio do sangue portal.

Não obstante, informações definitivas só foram fornecidas pelos estudos prospectivos com escolha aleatória dos grupos. Durante o período de 1960 a 1970, tornaram-se conhecidos os resultados de quatro pesquisas desse tipo. As três primeiras ${ }^{105-145-376}$ foram programadas para conhecer os efeitos da APC em cirróticos que ainda não tivessem apresentado sangramento digestivo. A derivação porto-cava foi, assim, executada com indicação “profilática”. Pretendia-se evitar a alta mortalidade conseqüente ao primeiro episódio hemorrágico ${ }^{273}$. Uniformemente, os três planos de investigação mostraram que o desvio do sangue portal não prolongava a sobrevida dos operados. Além disso, apesar de a mortalidade permanecer praticamente inalterada, a causa de morte mais freqüente diferiu radicalmente nos dois grupos. Nos controles prevaleceu a hemorragia digestiva e nos operados predominou a insuficiência hepática, inexistente antes do desvio. O quarto estudo prospectivo ${ }^{375}$ focalizou os efeitos da APC em cirróticos com pelo menos um episódio de sangramento. A operação foi realizada, portanto, com indicação "terapêutica". Após cinco anos de seguimento, obtiveram-se resultados semelhantes aos precedentes. $\mathrm{O}$ pequeno aumento observado na sobrevida dos operados não se mostrou estatisticamente significativo. Além disso, outros autores, analisando estes resultados, salientaram um aspecto adicional. Durante o período de estudo, a melhor evolução foi apresentada pelos controles sem recidiva hemorrágica. Viveram mais tempo com menor deterioração hepato-. celular do que os operados também sem sangramento pós-operatório. Tal comportamento revela que o desvio do sangue portal exerceu um efeito pernicioso na função hepatocelular, adicional ao esperado na própria evolução natural da cirrose ${ }^{853}$.

De 1970 para cá, dois estudos importantes confirmaram essas observações. Ambos analisaram o comportamento de cirróticos submetidos a derivações com indicação "terapêutica”. O primeiro comparou controles com pacientes submetidos a uma APC, e o segundo, por Galambos e col. ${ }^{269}$, comparou dois grupos submetidos, respectivamente, a uma 
derivação clássica e a uma derivação portal seletiva.

Após cinco anos, a pesquisa mais recente confirmou os resultados finais do projeto realizado na década anterior ${ }^{375}$. Isto é, a APC não prolongou a sobrevida de cirróticos com pelo menos um episódio hemorrágico antes da cirurgia. Paralelamente, o estudo de Galambos e col.269 comprovou claramente os efeitos perniciosos do desvio do sangue portal para a função das células hepáticas.Comodescrito adiante com mais pormenores, esses autores verificaram sobrevida e preservação hepatocelular nitidamente superiores nos pacientes com DPS. Além disso, o estudo mostrou, pela primeira vez, que cirróticos protegidos contra recidivas hemorrágicas, mas sem desvio global do sangue portal, evoluem melhor do que o esperado. Realmente, observaram, neste grupo, mortalidade tàrdia baixa durante os cinco anos de seguimento (5\%).

Parece que, desta forma, fica afastada a interpretação original de Blakemore 69. Em pacientes com APC, o agravamento da disfunção hepática decorre tanto do desvio do sangue portal quanto da evolução natural da moléstia. É possível que em muitos casos o primeiro seja mais importante.

Entretanto, existem algumas observações isoladas discordantes desta linha de idéias. Devem ser citadas, apesar do pequeno número, para demonstrar que alguns aspectos do problema continuam sem explicação.

- Phillip Sandblom, da Universidade de Lund na Suécia ${ }^{679}$, estudou 355 casos consecutivos de cirrose hepática com APC “terapêutica”. Refere preservação razoável da função hepática mesmo após seguimento tardio. Cita baixa incidência de EPS e sobrevida maior que a mencionada por outros autores em pacientes semelhantes operados em outros centros ${ }^{146}$. Compara, retrospectivamente, a evolução de cirróticos sangrantes não operados com seus pacientes submetidos à APC. Constata evidente aumento de sobrevida nos últimos. Atribui seus resultados ao critério adotado na indicação da cirurgia. Aceitando as idéias expressas há quase dez anos por Warren e seu grupo ${ }^{851}$, indica a operação apenas em pacientes com fluxo portal hepatopetal reduzido. Porém, essa explicação não parece suficiente para justificar a discrepância entre seus resultados e os da maioria dos autores. Por exemplo, Arthur P. Voorhees, sucessor de Blakemore na Universidade de Colúmbia e membro da escola que iniciou e difundiu a APC, refere resultados muito diferentes. Reduziu em cerca de $75 \%$ suas indicações operatórias, ao estudar o grupo mais numeroso de cirróticos submetidos a APC nos E.U.A. A análise retrospectiva de seu material demonstrou que, após dois anos de cirurgia, mais de $70 \%$ dos operados tinham morrido ou apresentavam morbidade em grau suficiente para impedir uma vida normal ${ }^{334}$.

- aspectos peculiares foram observados no seguimento tardio de treze pacientes com APC e glicogenose hepática ${ }^{772}$ e no seguimento imediato de uma paciente com desvio portal e hiperlipoproteinemia ${ }^{764}$. Apesar dos efeitos morfológicos já citados, esses pacientes toleraram muito bem o desvio do sangue portal. Não apresentaram sinais de insuficiência hepática ou alterações neurológicas de qualquer tipo. Entretanto a impunidade funcional não se repetiu em portadores de moléstias hepáticas não evolutivas de outro tipo. Turcotte ${ }^{821}$ aponta, dois anos após a operação, grave EPS e deterioração hepatocelular num paciente portador de hipertensão portal primária e fígado aparentemente normal antes da cirurgia. Portanto, é lícito questionar quais efeitos teriam exercido as alterações metabólicas dos pacientes com glicogenose e hiperlipoproteinemia na prevenção dos efeitos funcionais hepatocelulares da APC. No momento, qual- 
quer discussão apresenta caráter apenas especulativo, o que a afasta da finalidade desta revisão.

EFEITOS NA CAPACIDADE DE REGENERAÇÃO DO FÍGADO

A regeneração do tecido hepático, estimulada por extirpação cirúrgica, parece ter sido verificada pela primeira vez, em cães, por Ponfick em $1894{ }^{588}$. A partir de então, inúmeros autores a demonstraram também em ratos ${ }^{350}$, coelhos ${ }^{499}$, e maca$\cos { }^{475}$. Refere-se intensidade inversamente proporcional à evolução na escala filogenética ${ }^{475}$.

A regeneração inclui hipertrofia e hiperplasia do tecido remanescente, com alterações bioquímicas intracelulares já conhecidas ${ }^{100-859}$. Esses processos implicam grande consumo de energia e representam prova de esforço para os hepatócitos. Desta maneira, a capacidade de regeneração constitui excelente parâmetro para a avaliação da vitalidade das células hepáticas e dos fatores que sobre ela atuam.

Foram despendidos esforços para esclarecer o estímulo e controle do complexo mecanismo da regeneração hepática. A interpretação dos resultados em
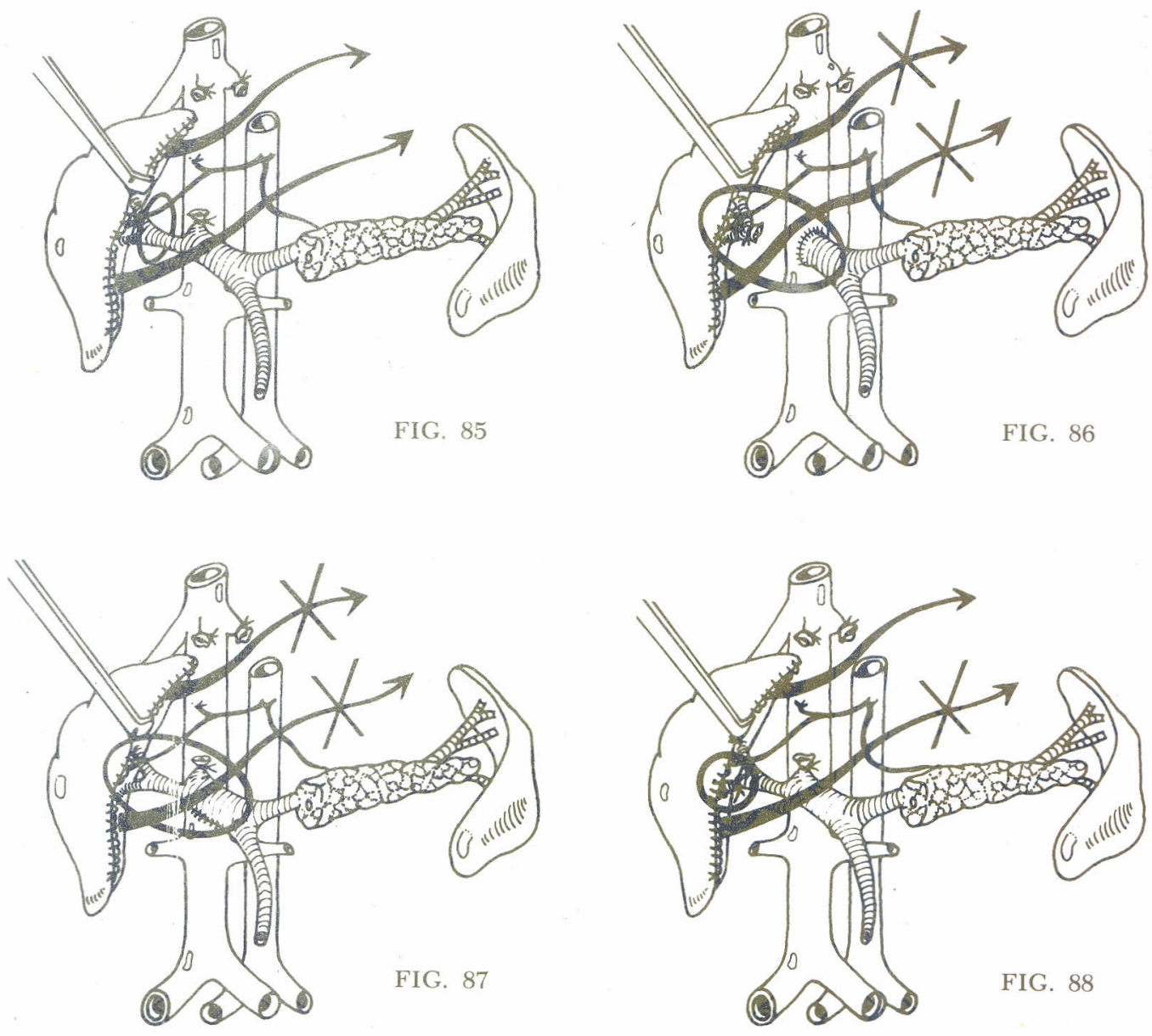

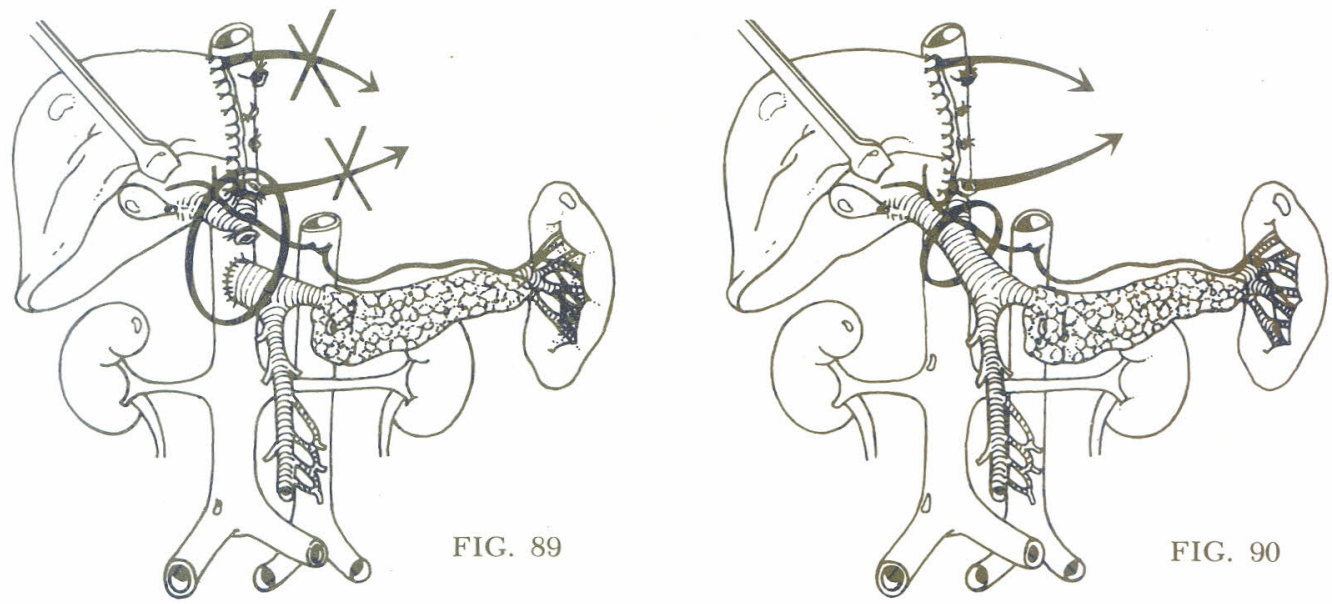

diferentes modelos originou várias controvérsias. Definiu, porém, um ponto de vista uniforme quanto à importância do sangue portal. A falta de discussão quanto a este aspecto explica-se pela observação constante de que o desvio do sangue portal para a circulação sistêmica elimina a capacidade de regeneração estimulada por ressecções ampliadas.

Numa fase inicial, esta dependência foi demonstrada, pela escola de Mann, em cães (Fig. 85), e por outros, em coelhos e ratos ${ }^{472-474}$. Os autores obtiveram o desvio do sangue portal por uma FE (Fig. 86), APCLL (Fig. 87) ou mesmo pela simples ligadura de ramos isolados da veia porta (Fig. 88).

Mannix e col., em $1956^{475}$, comprovaram ausência de regeneração e mesmo atrofia do remanescente após ressecção de $50 \%$ do parênquima hepático em macacos Rhesus com FE (Fig. 89). Tal comportamento diferiu nitidamente do observado nos controles, nas mesmas condições, mas sem $\mathrm{FE}$, nos quais houve regeneração de $27 \%$ (Fig. 90). Recentemente, desenvolveram-se técnicas para transplantes de fígado em animais de pequeno porte. Lee e col., em 1969429, constataram, em ratos, ausência de regeneração em isotransplantes de fígado, enxertados em situação heterotópica e sem irrigação portal (Fig. 91).

Se a falta de regeneração em animais com FE é aceita sem discussão, a explicação do efeito inibidor provocou controvérsia que será examinada detalhadamente. Sua evolução cronológica influiu e, por outro lado, reflete a modificação que caracteriza a passagem do "período das derivações clássicas" para o "período da dúvida”, citados no item anterior.

Ao interpretar suas observações iniciais, a escola de $\mathrm{Mann}^{474}$ considerou que o estímulo para o processo de rege-

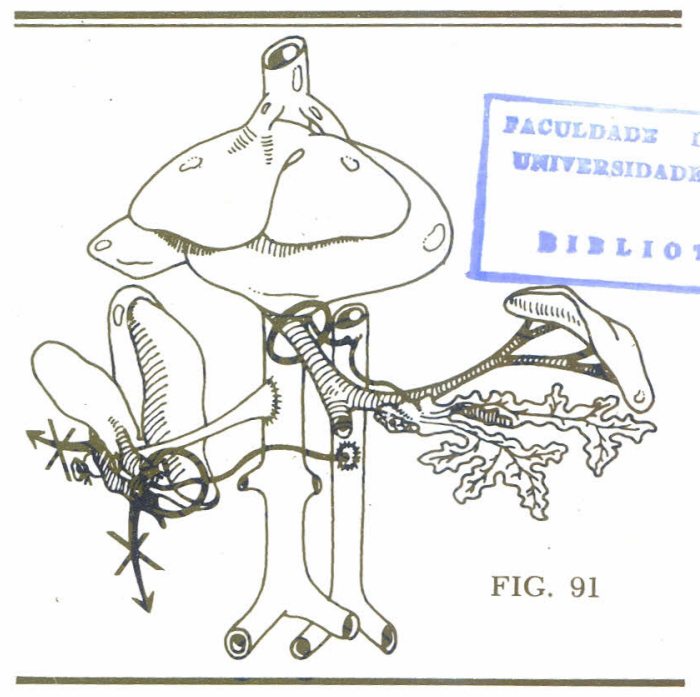


neração hepática era dependente e, muito provavelmente, estaria contido no. sangue portal sob forma de um componente bioquímico. Com o aparecimento do período das derivações globais, esta teoria "qualitativa" foi contestada por uma série de autores. Tentaram provar que, pelo contrário, a falta de regeneração dependia apenas da redução do fluxo hepático total. Os primeiros defensores dessas idéias foram Grindlay e Bollman $^{316}$, que estudaram, em cães, o processo de regeneração após ressecções de $70 \%$ do parênquima hepático. Demonstraram que os efeitos inibidores exercidos pelo desvio do sangue portal podiam ser evitados pela constrição da veia supra-hepática (Fig. 92). Concluíram que os efeitos da $\mathrm{FE}$ na regeneração eram decorrentes da falta de sangue nos sinusóides e podiam ser impedidos por qualquer manobra que garantisse seu enchimento normal.

Coube, porém, a Child III e col., em $1953^{130}$, divulgar a teoria "quantitativa" através de uma série de experiências cujos resultados constituem referência clássica. Entretanto, a grande repercussão dessas constatações pode ser atribuída a vários fatores independentes dos resultados apresentados. Entre eles, destaca-se a avidez existente na época para informações comprovando a inocui-

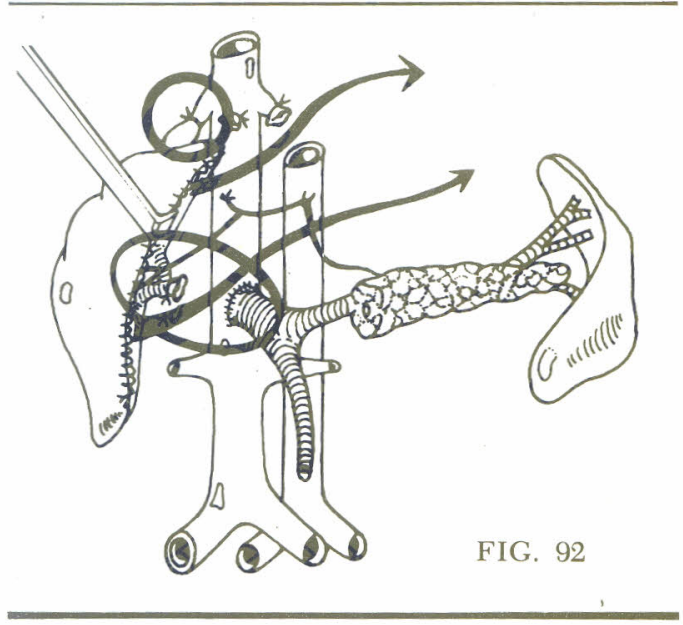

dade da FE. Devem ser citados, também, o prestígio dos autores e o tipo engenhoso do modelo empregado. Estes aspectos podem ser relacionados com a pouca atenção conferida ao número insuficiente de animais analisados e aos acidentes ocorridos durante as experiências. O processo de regeneração foi estudado, em cães, após ressecção de $70 \%$ do parênquima hepático. Os modelos tinham diferentes tipos de irrigação hepãtica. No primeiro lote, a hepatectomia foi efetuada trinta dias depois de uma transposição porto-cava total (modelo de Child) (Fig. 93). Dos catorze animais incluídos nesse grupo, seis não foram aproveitados por complicações e acidentes. Nos oito restantes, notou-se regeneração entre 20 e $80 \%$, com uma média de $50 \%$. No segundo lote a hepatectomia foi realizada em seis cães controles (Fig. 94). Verificou-se regeneração entre 45 e $114 \%$, com média de $75 \%$. Finalmente, no terceiro lote, a ressecção foi feita em quatro cães com FE (Fig. 95). Destes, nenhum pôde ser analisado até o fim do período programado, por erros técnicos e acidentes no pós-operatório. No curto período estudado, não constataram regeneração do parênquima hepático. Baseados em tais resultados, concluíram que "o sangue portal não é indispensável para a regeneração hepática e que sua falta, em animais com FE, é conseqüência principalmente da redução no fluxo hepático total".

Corroborando esse ponto de vista, Fisher e col., em 1954 ${ }^{253}$, demonstraram, também em cães, a possibilidade de evitar os efeitos da FE na regeneração hepática substituindo o sangue portal por sangue arterial. Verificaram nos animais controles que a ressecção de $43 \%$ do parênquima hepático determinava regeneração de $80 \%$ (Fig. 96) após trinta a sessenta dias. Pelo contrário, em animais com FE (Fig. 97) além da falta de regeneração notaram visível atrofia do remanescente. Finalmente, em animais com 

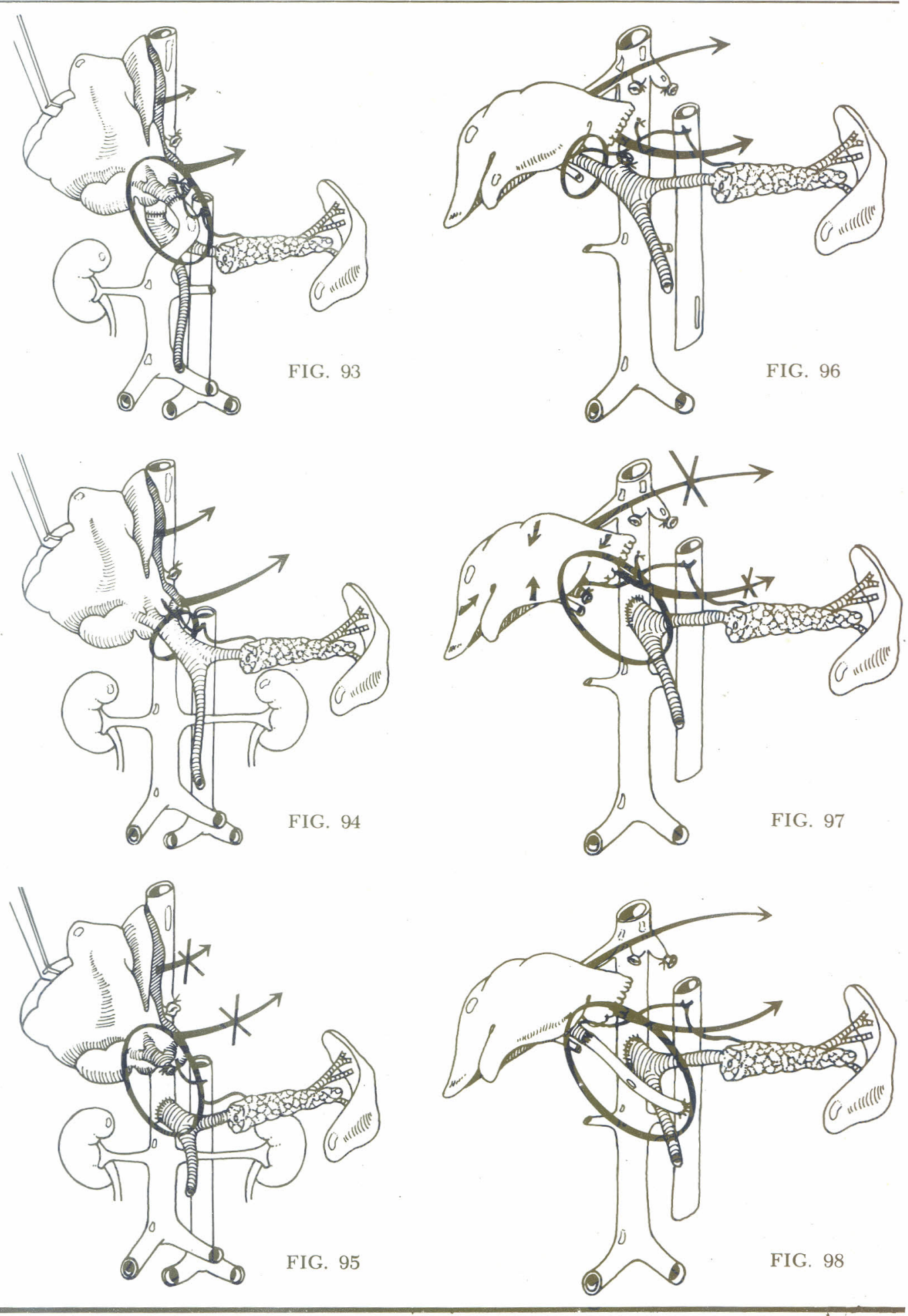
FE mas com fluxo hepático total conservado ou mesmo aumentado pela "arterialização” da veia porta (Fig. 98), observaram que a regeneração excedia a dos controles, atingindo $103 \%$ em média. Concluíram que "o sangue portal é desnecessário para a regeneração e que o aumento do fluxo hepático total e conseqüente fornecimento adicional de oxigênio são capazes de estimular o processo".

Além disso, Wexler e col.870 impediram os efeitos inibidores da FE em cães submetidos a ressecção de $50 \%$ do fígado, realizando uma anastomose término-terminal entre a veia renal direita e o coto hepático da veia porta (Fig. 99). Na realidade, esta preparação mimetiza o modelo de Child. Apresenta a vantagem de dirigir para a veia porta sangue mais rico e melhor oxigenado do que aquele da veia cava inferior. De fato, a saturação de oxigênio da veia renal esquerda é superior à do sangue da veia cava $^{870}$.

A teoria quantitativa continuou merecendo a preferência dos autores durante todo o período das derivações globais. Com o advento porém dos estudos prospectivos e as dúvidas que levantaram sobre a impunidade da FE, o problema foi reexaminado em modelos mais elaborados.

Sigel e seu grupo apresentaram, em

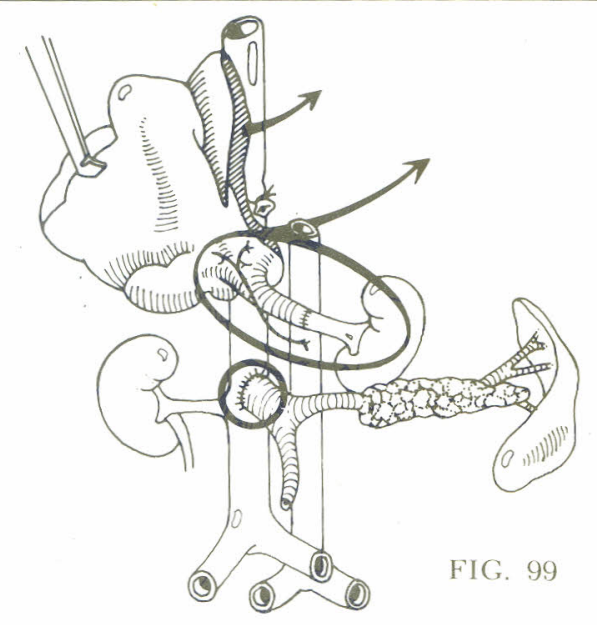

duas séries de experiências, aspectos úteis para a compreensão dos efeitos da $\mathrm{FE}$ na regeneração hepática. Inicialmente analisaram, em cães, a regeneração em autotransplantes heterotópicos de fígado, correspondendo de 5 a $10 \%$ do órgão principal. Notaram que, após oito semanas, o enxerto revelava nítida atrofia. (Fig. 100).

Esta não ocorreu quando o sangue portal foi desviado para o transplante (FE associada à ressecção de $70 \%$ do fígado principal) (Fig. 101). Demonstraram aumento do seu peso devido a ùm processo de proliferação celular. Todavia, nesse modelo não foi possível separar os efeitos no trofismo das células do enxerto daqueles exercidos sobre o processo de regeneração em si $^{731}$. Para esclarecer a questão, os mesmos autores ${ }^{729}$ realizaram, em modelos semelhantes, hepatectomia de $70 \%$ no fígado "in situ" (Fig. 102) ou apenas FE (Fig. 103). Definiram, dessa maneira, a existência de mecanismos diferentes para estímulos e controle da hiperplasia e da hipertrofia da regeneração. Enquanto a hepatectomia parcial do fígado homotópico determinou hiperplasia no enxerto (evidenciada pelo aumento de $\mathrm{ADN}$ ), a $\mathrm{FE}$ sem resšecção causava apenas hipertrofia. Estes dados foram completados por Price e col.604. Estudaram cães nos quais um lobo, correspondente a $30 \%$ do parênquima hepático, foi ressecado; um outro, correspondendo a $40 \%$, foi transplantado para a fossa ilíaca direita e o remanescente, correspondendo a 30\%, permanecia "in situ". Os autotransplantes recebiam sangue arterial acrescido de sangue venoso da veia cava ou da veia mesentérica superior. Observaram regeneração apenas nos últimos. Concluíram, então, que o sangue portal contém fatores indispensáveis para o processo e que são clareados numa única passagem pelo fígado. "in situ".

Nas experiências com autotransplantes heterotópicos, tornou-se aparente uma 

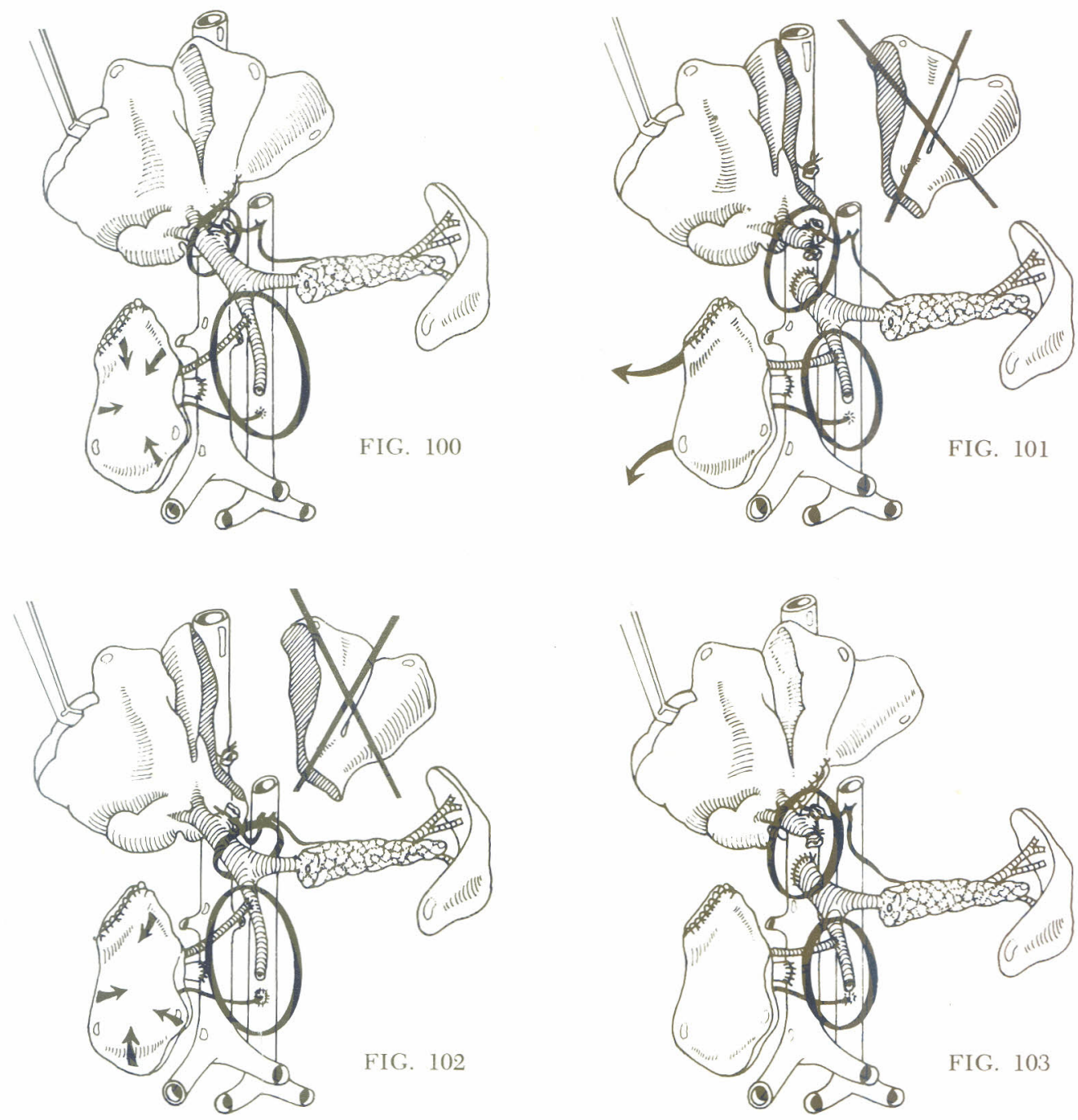

competição entre o fígado "in situ" e o segmento transplantado pelos elementos contidos no sangue portal. Como a retirada do fragmento a ser autotransplantado heterotopicamente representava uma hepatectomia no fígado "in situ", surgiram dúvidas quanto ao caráter e à origem desses fatores. Poderiam ser substâncias produzidas ou liberadas pelo parênquima “in situ”, em resposta ao estímulo da resseç̧ão, como também poderiam ser constituintes normais do sangue portal. A elucidação desta dúvida foi possível com o desenvolvimento da técnica para execução de transplante de fígado em ratos ${ }^{428427}$. Pode-se efetuar um número mais elevado de experiências, obtendo-se resultados de maior valor estatístico. Além disso, a disponibilidade de animais homozigotos possibilitou estudos adicionais sobre efeitos do sangue portal em transplantes heterotópicos. Isotransplantes segmentares ou totais não implicam ressecção parcial do órgão 

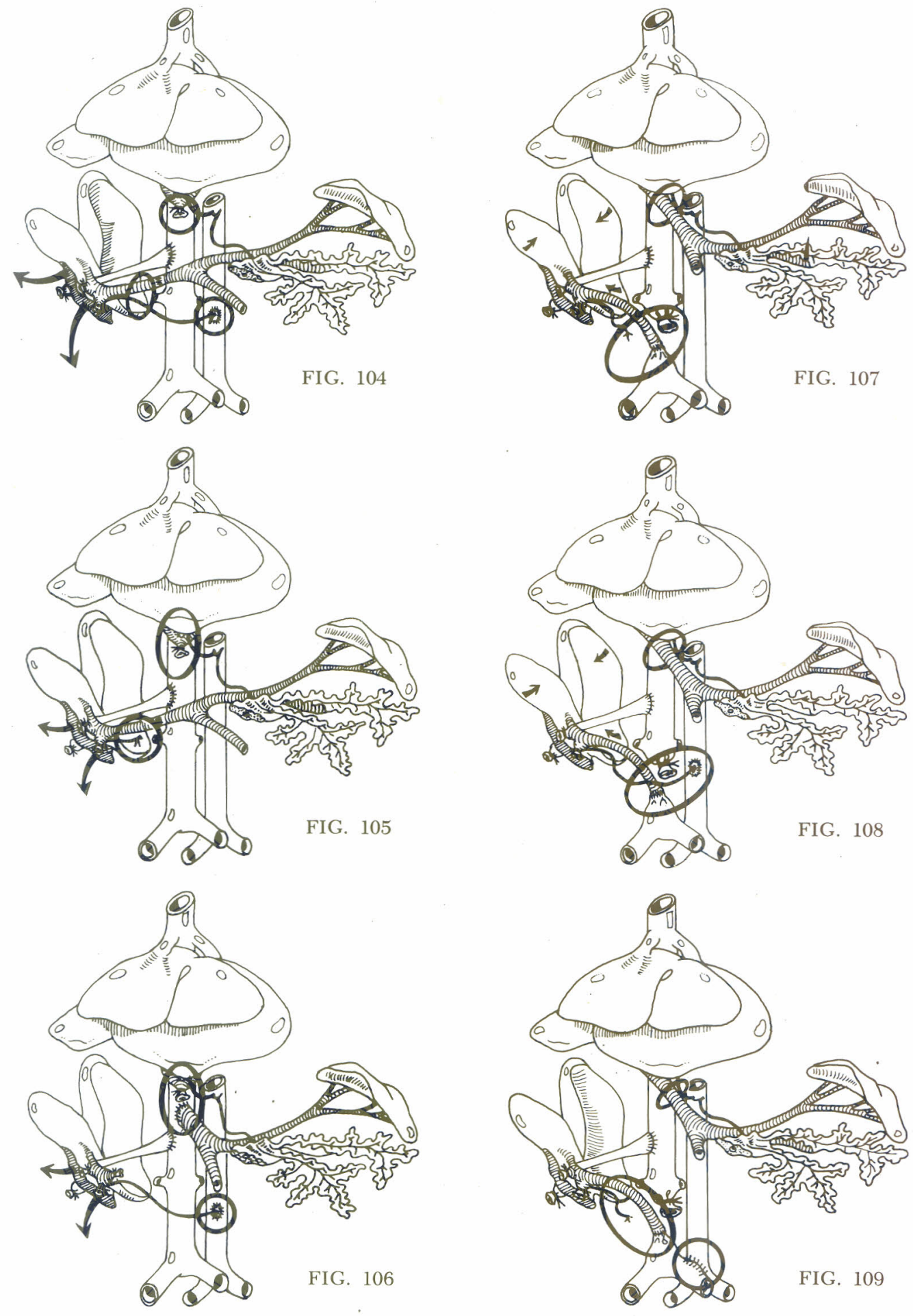
"in situ" nem apresentam sobreposição de efeitos de rejeição. Assim, Lee e col.429 forneceram esclarecimentos importantes para a questão. Examinaram 196 ratos com isotransplante heterotópico correspondente a $30 \%$ do parênquima hepático, enxertado na fossa ilíaca direita. Provaram que a revascularização dupla do enxerto com sangue portal e arterial permitia regeneração hepática com intensidade máxima (Fig. 104). Os transplantes perfundidos apenas por sangue portal (antes de sua passagem pelo fígado autóctone) também apresentavam o processo, ainda que com menor intensidade (Figs. 105-106). Em oposição, os desprovidos de sangue portal (Fig. 107) mostraram, além de falta de regeneração, atrofia celular mesmo quando supridos por grande fluxo de sangue sistêmico (Figs. 108-109).

Chandler e col., em $1971^{121}$, esclareceram melhor esse aspecto do problema. Aplicaram isotransplantes parciais, correspondendo a $30 \%$ do fígado doador, enxertados heterotopicamente em 214 ratos. O sangue portal do receptor era mantido em direção ao fígado autóctone (Fig. 110), ou derivado exclusivamente para o transplante (Fig. 111), ou dividido entre ambos por meio de uma FE no receptor (Fig. 112). Cada um destes grupos era subdividido em outros dois: no primeiro, o fígado autóctone permanecia intato (Figs. 110-111-112) e no outro, era ressecado em 70\% (Figs. 113-114-115). Demonstraram que o fator estimulante para a regeneração não era produzido pelo parênquima do remanescente autóctone, mas constituído por um componente normal do sangue portal. Verificaram ainda que uma única passagem pelo fígado "in situ" eliminava o efeito estimulante no transplante.

A teoria quantitativa foi assim fortemente questionada pelos resultados conseguidos em auto e isotransplantes. Entretanto, foi definitivamente afastada pelos trabalhos mais recentes da escola de

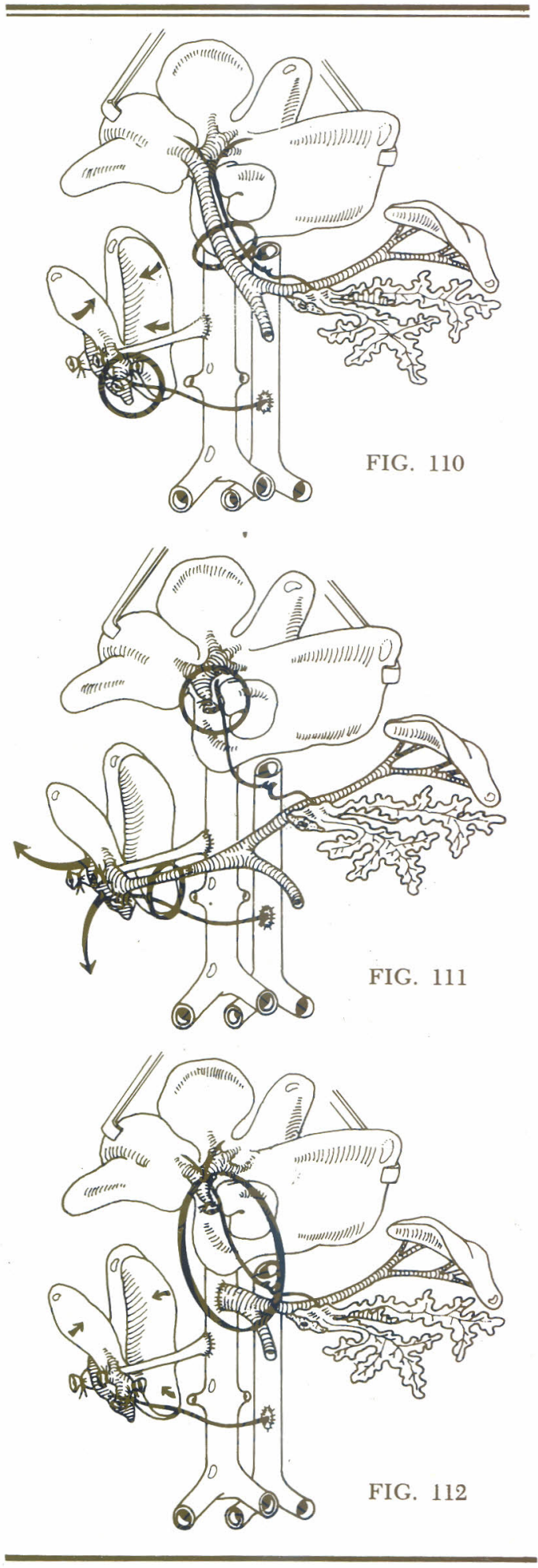




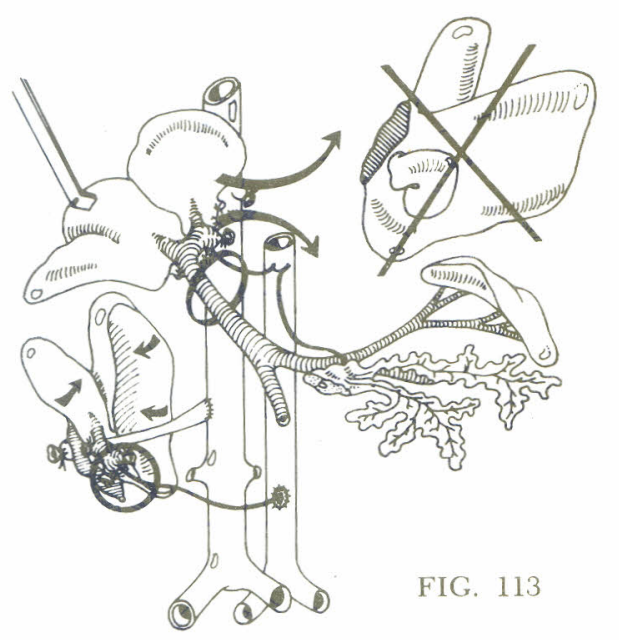

Fisher, que até há pouco defendia aquele ponto de vista. Utilizaram diferentes modelos em cerca de trezentos ratos. Confirmaram a existência, no sangue portal, de um fator indispensável para a regeneração hepática, demonstrando também um dos mecanismos que regulam sua ação estimulante. Inicialmente empregaram transplantes heterotópicos totais ou parciais, enxertados em receptores com fígado autóctone intato ou parcialmente ressecado, cujo fluxo portal permanecia normal ou era desviado por uma FE. Comprovaram a existência de um controle extracelular da regeneração hepática. Denominaram PBF um fator localizado no sangue portal. Este mostrou-se tanto mais atuante quanto menor o parênquima do remanescente. Notaram, ainda, que o fator não era destruído nem inibido no sangue sistêmico, desaparecendo após uma única passagem pelo fígado autóctone ou transplantado $^{254}$. Estes dados confirmaram aqueles de Christensen e Jacobsen ${ }^{134}$ em ratos isogênicos conectados em parabiose. Chamaram a atenção também para o fato de que o PBF age em função de um desequilíbrio quantitativo entre sua concentração e o número de células do fígado remanescente.

Neste momento, surgiu interesse em situar o órgão que produz o fator estimulante da regeneração. A escola de Orloff obteve essa informação em duas experiências efetuadas em modelos muito engenhosos. Na primeira, Sgro e col., em $1973^{713}$, realizaram, em ratos, ressecção de $70 \%$ do parênquima hepático (Fig. 116) associada, respectivamente, a ressecção do intestino delgado (Fig. 117), do baço, estômago, duodeno e pâncreas (Fig. 118), ressecção do estômago, baço e duodeno (Fig. 119), resseç̧ão do estômago (Fig. 120) e ressecção apenas do pâncreas (Fig. 121). Notaram regeneração do remanescente somente nos modelos nos quais não se procedeu à extirpação do pâncreas e duodeno. Excluíram, 
assim, o intestino delgado, o baço e o estômago como a sede do fator em questão. A seguir, Broelsch e col., em $1974^{96}$, realizaram, também em ratos, isotransplantes parciais, correspondendo a $30 \%$ do fígado, acoplados a diferentes órgãos. $\mathrm{O}$ enxerto, uma vez na fossa ilíaca direita do receptor, recebia sangue portal proveniente apenas dos outros órgãos com ele transplantados. Empregaram modelos com transplantes de fígado associados respectivamente ao intestino delgado (Fig. 122), duodeno (Fig. 123), duodeno e pâncreas (Fig. 124) e apenas pâncreas (Fig. 125). Demonstraram que o fator relacionado com a regeneração tinha sua origem no pâncreas confirmando, assim, as experiências anteriores.

A dependência da regeneração na concentração dos fatores presentes no sangue portal foi fortalecida pelas experiências já citadas da escola de Ozawa $^{566-567-568-569}$ que identificou a insulina como sendo o fator atuante. Estudou a função das mitocôndrias das células hepáticas, analisando a velocidade de síntese de ATP e a capacidade de fosforilação. Separaram essas organelas por ultracentrifugação de homogenatos de fígado de coelhos e ratos com fluxo portal normal, interrompido ou aumentado. Comprovaram uma dependência da função das mitocôndrias no aporte de insulina e na sua concentração no sangue portal. Após ressecções ampliadas, a relação quantitativa normal entre o número de células perfundidas e a insulina do sangue portal se altera. Em conseqüência as mitocôndrias seriam mais estimuladas, aumentando a produção de ATP. Explicam, dessa maneira, o aumento da síntese de ADN e a hiperplasia que caracteriza a regeneração hepática. Acreditam que com o evoluir da regeneração restabelece-se, progressivamente, a relação quantitativa normal entre a população de células perfundidas e a quantidade de insulina a elas ofertada. Sugerem que

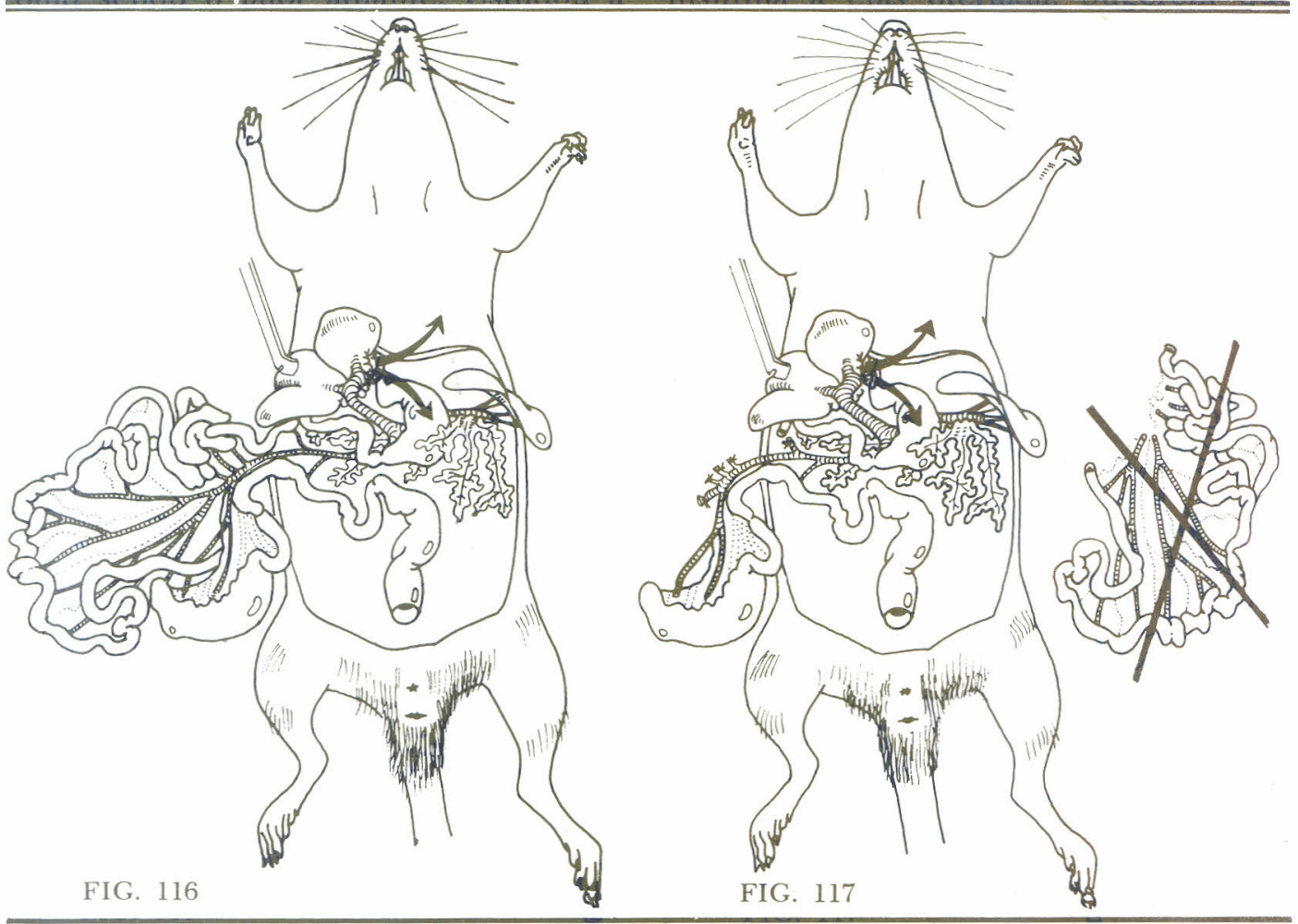




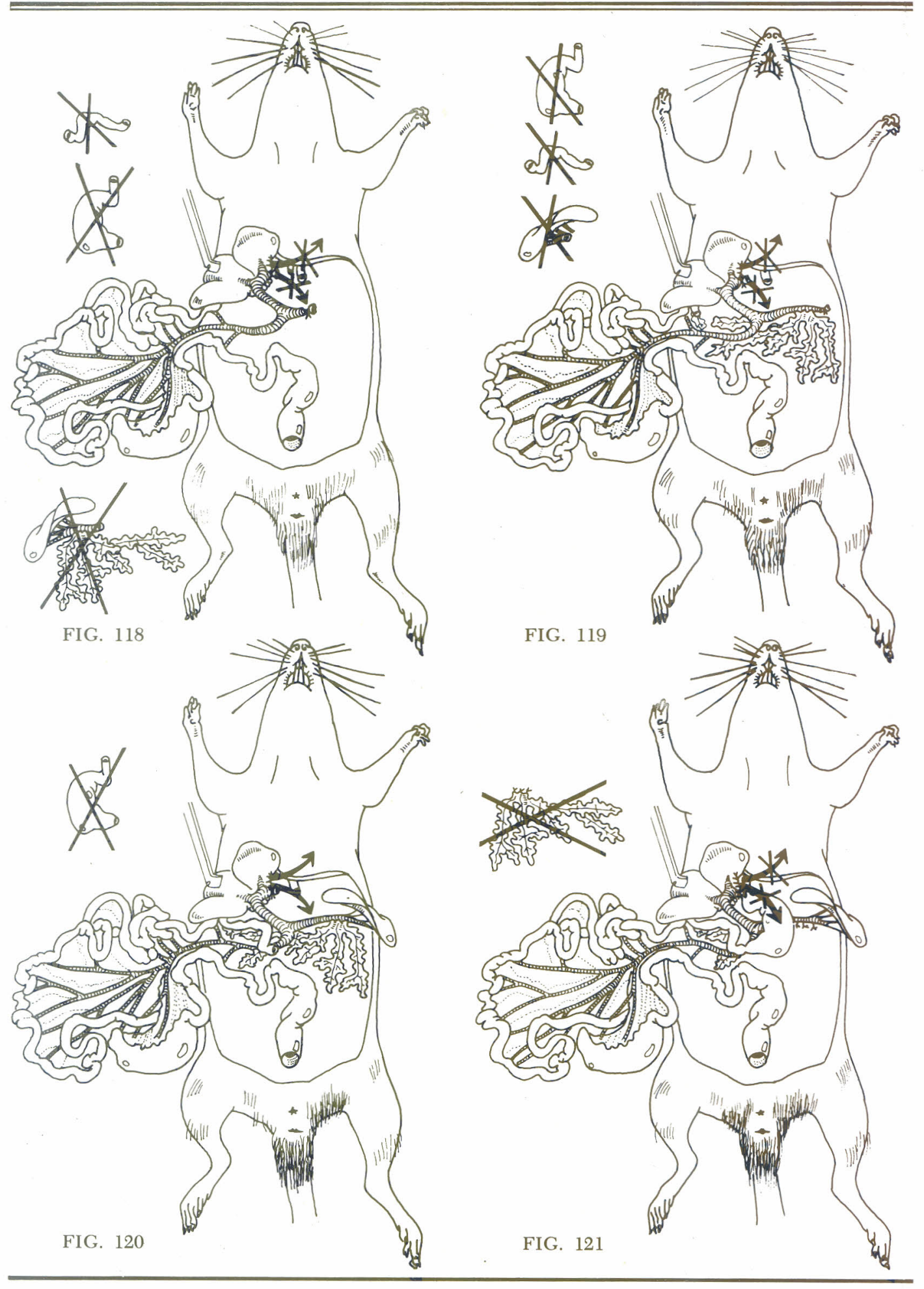


este mecanismo constitui o fator que interrompe a regeneração, quando o remanescente readquire o tamanho do órgão primitivo.

Aceitando a hipótese que relaciona a concentração dos fatores hepatotróficos com a intensidade da regeneração, é fácil compreender a persistência do processo, ainda que com intensidade reduzida, nos modelos com transposição porto-cava total $^{130}$, nos modelos com FE e arterialização do coto hepático da veia porta ${ }^{253} \mathrm{e}$ nos modelos com anastomoșe renoportal ${ }^{870}$. Realmente nestas condições, os fatores portais continuam atingindo as células hepáticas, mas em concentração mais baixa.

Esta linha de idéias foi fortalecida por Starzl e col., em $1975^{770}$, que aplicaram os modelos com derivação portal seletiva no estudo da regeneração hepática de cães. Inicialmente, verificaram que, mesmo sem ressecção simultânea, a derivação venosa provoçou aumento da di-
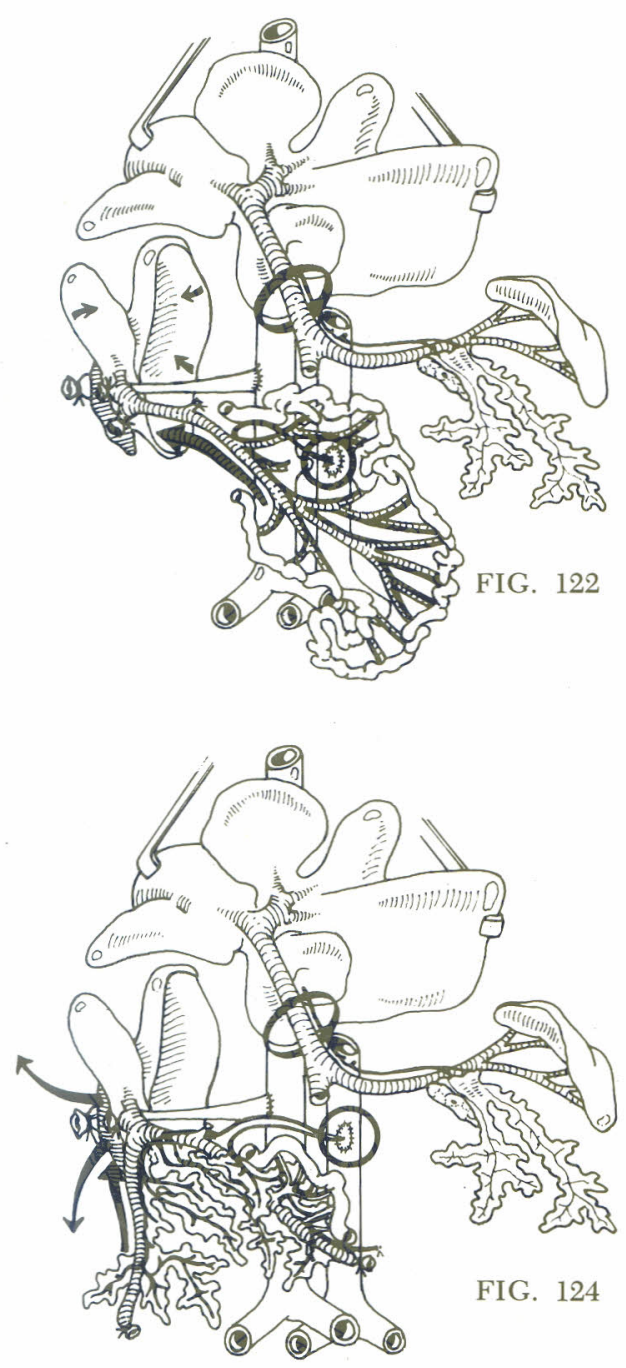
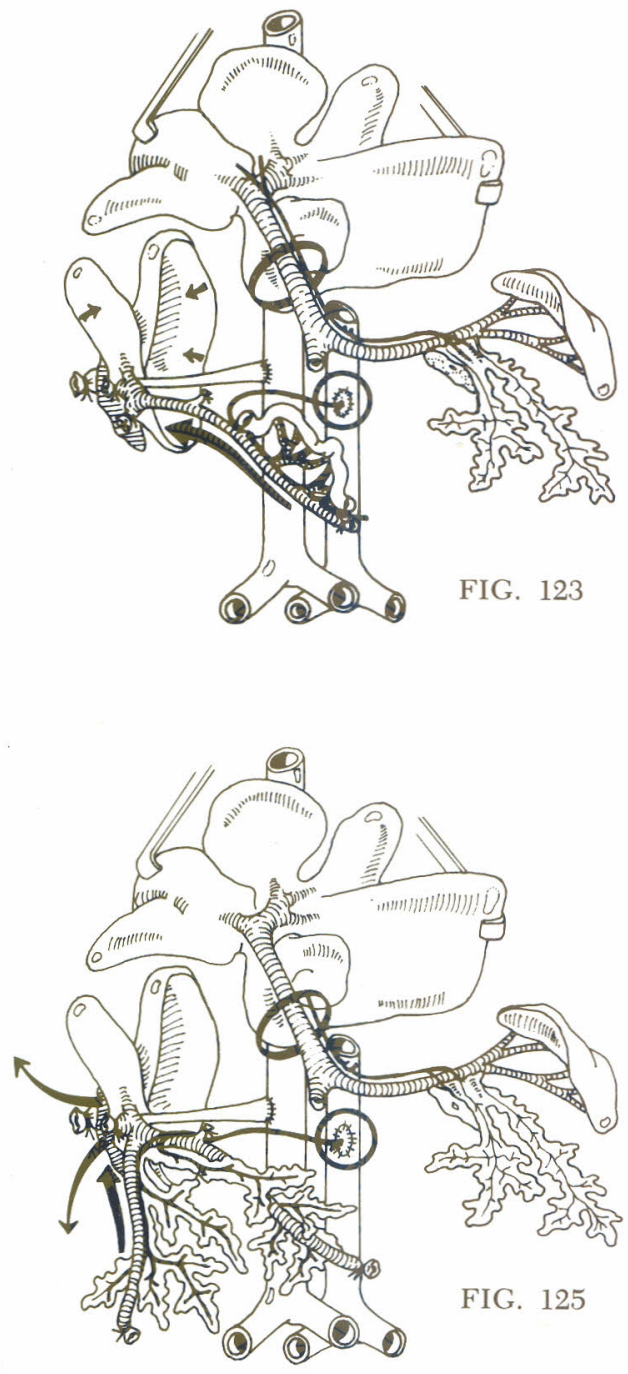
visão celular. Os lobos hepáticos perfundidos com sangue pancreático apresentaram hipertrofia e hiperplasia em relação aos restantes perfundidos apenas com sangue intestinal. Em alguns animais com sistema porta normal, realizaram concomitantemente ressecção de 30 a $60 \%$ do parênquima hepático (Fig. 126). Em outros, notaram que o tecido perfundido com sangue pancreático mostrava regeneração mais evidente do que o parênquima perfundido com sangue intestinal, ainda que ambos participassem do processo (Fig. 127). O comportamento apresentado pelo tecido perfundido por sangue pancreático não persistiu em modelos semelhantes tratados por aloxane (Fig. 128) ou submetidos a pancreatectomia total (Fig. 129). Definiram assim a insulina como um elemento atuante no processo de regeneração. O efeito inibidor da diabete ocorreu também em cães com transposição porto-cava. Nestes, metade do parênquima hepático recebia sangue pancreático e intestinal e a outra, sangue venoso sistêmico proveniente da veia cava inferior (Figs. 130-131-132). Estas observações permitiram concluir
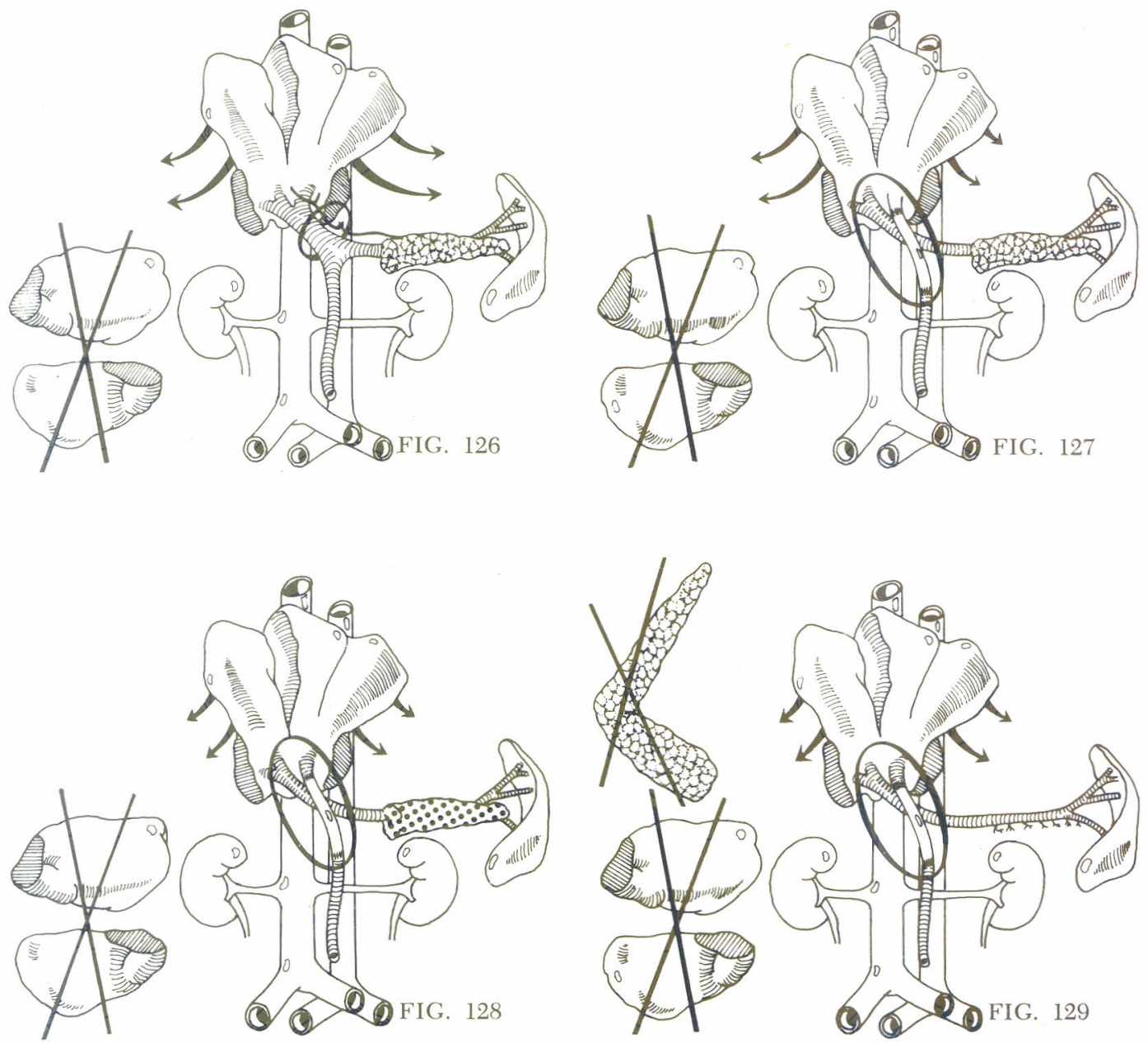
que os fatores portais atuam nitidamente no processo de regeneração e são pacialmente inativados numa única passagem pelos sinusóides. Esta conclusão foi possível graças às particularidades dos modelos com derivação portal superseletiva. $O$ sangue pancreático atinge as células hepáticas do lado oposto somente depois de passar pelos sinusóides do parênquima para o qual é dirigido. Pelo contrário, em modelos com FE o sangue portal contendo insulina recémsintetizada atinge o parênquima hepático pela artéria hepática. Nesta passagem encontra-se diluída mas sem nunca ter estado em contato com as células hepáticas. Por outro lado, os modelos empregados nesta série de expériências acrescentaram uma prova contra a teoria quantitativa. Com efeito, o desaparecimento dos benefícios no parênquima perfundido com sangue pancreático, após a indução de diabete, só pode ser atribuído à retirada da insulina. O fluxo sanguíneo dirigido ao parênquima em observação permaneceu inalterado.

O efeito da diabete na regeneração contribuiu também para esclarecer o papel do glucagon nesse fenômeno. Em publicações prévias, os mesmos ${ }^{765}$ e ou$\operatorname{tros}^{102}$ autores consideraram a relação insulina/glucagon mais importante que a insulina isolada. Outros consideraram o glucagon como o fator principal ${ }^{601-877}$.

Entretanto, o efeito inibidor exercido pelo aloxane e pela pancreatectomia total suscitou dúvidas sobre a importância do glucagon. Sua concentração não foi alterada pelos processos diabetogênicos e não se verificou regeneração.

Os modelos diabéticos forneceram também informações inéditas. Em animais com derivação portal super-seletiva e hepatectomia de $30 \%$, o estímulo regenerativo ocorreu apenas no parênquima perfundido com sangue pancreático. A administração de aloxane ou a pancreatectomia total diminuiu a intensidade do processo. No entanto, nestes últimos,

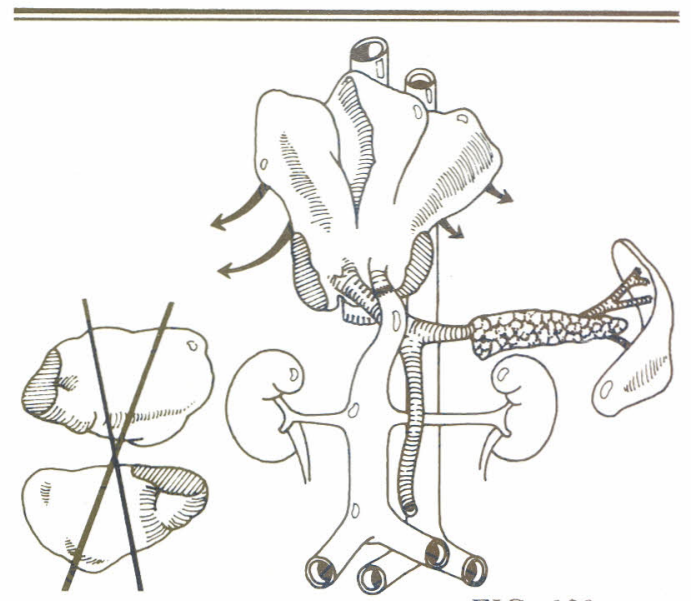

FIG. 130

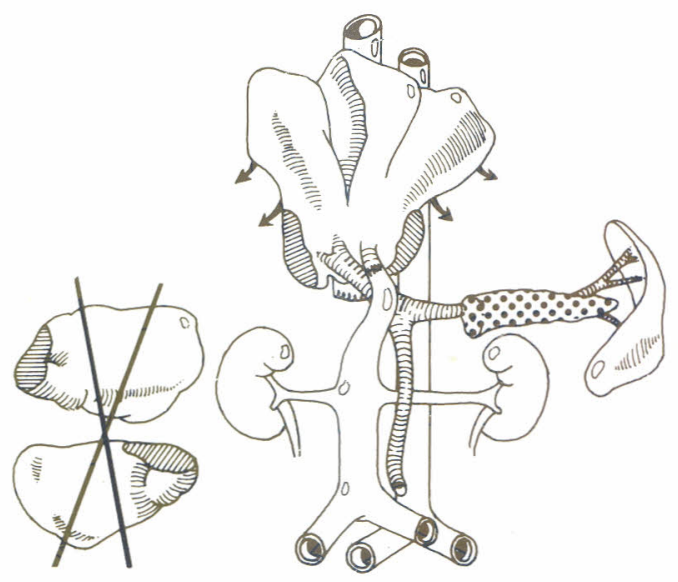

FIG. 131
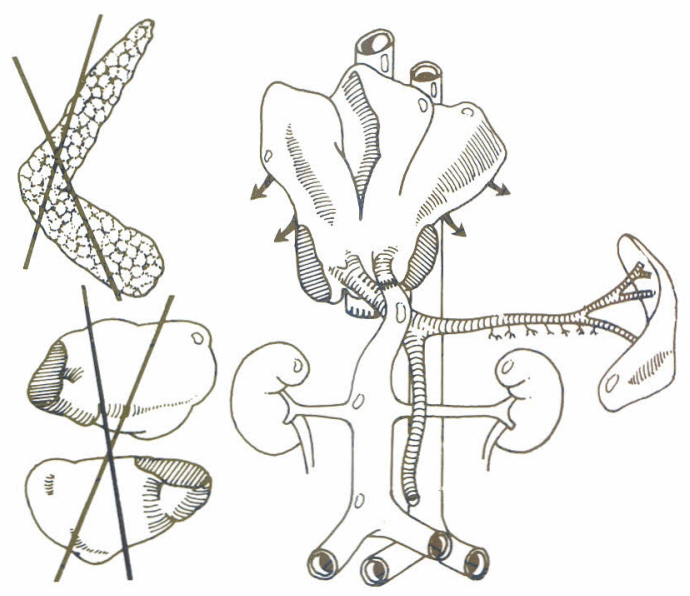

FIG. 132 
a administração subcutânea de insulina transferiu o processo regenerativo para o lobo sem sangue pancreático.

Demonstrou-se, assim, que no sangue intestinal existe também um fator capaz de estimular a regeneração, desde que associado à insulina, ainda que exógena. Compreende-se, desta forma, que a transferência não tenha ocorrido nos modelos sem a administração subcutânea.

A demonstração de um fator estimulante da regeneração hepática no sangue intestinal, mesmo dependente da insulina, facilita a interpretação de resultados até então contraditórios como os de Fisher e col. ${ }^{255}$ que localizaram no intestino a fonte de um importante estímulo para a regeneração. Entretanto permanecem algumas informações experimentais ainda carentes de explicação:

- Price e col. ${ }^{601-602}$ e Max e col.487 conseguiram regeneração após hepatectomia parcial em cães cujos órgãos do sistema porta tinham sido previamente extirpados. Nos seus modelos, o coto hepático da veia porta recebe sangue sistêmico pela veia cava ou diretamente da aorta.

- Bucher e Swaffield ${ }^{101}$ constataram aumento na síntese de ADN nos hepatócitos do fígado de ratos, nos quais tinham retirado previamente o estômago, o duodeno, o intestino, o pâncreas e o baço (Fig. 133). Este modelo difere dos dois precedentes, visto que a veia porta é ligada e o parênquima hepático remanescente permanece irrigado apenas pela artéria hepática. Devem-se citar também os resultados obtidos em animais eviscerados, não hepatectomizados. Observouse aumento da atividade de síntese de ADN, correspondente a um processo de hiperplasia equivalente ao esperado após resseção de $43 \%$ do parênquima hepático $^{601}$;

- a situação destes últimos dados, no contexto do problema, pode ser facilitada pelo conhecimento de que a proliferação de células hepáticas de fígado intato pode ser induzida, em ratos, também por diferentes tipos de dieta, hormônios e outras substâncias ${ }^{25-426-723-724}$.

A análise conjunta de todas essas informações mostra inquestionavelmente a presença no sangue portal de fatores atuantes na regeneração do fígado. Destaca-se a insulina que age, provavelmente, em função da sua concentração. O glucagon parece participar do processo. Fatores não dependentes do sistema porta também influem possivelmente potencializados pelos substratos recém-absorvidos no intestino. Como para os efeitos morfológicos, é possível que o processo regenerativo seja controlado por múltiplos fatores interdependentes entre si .

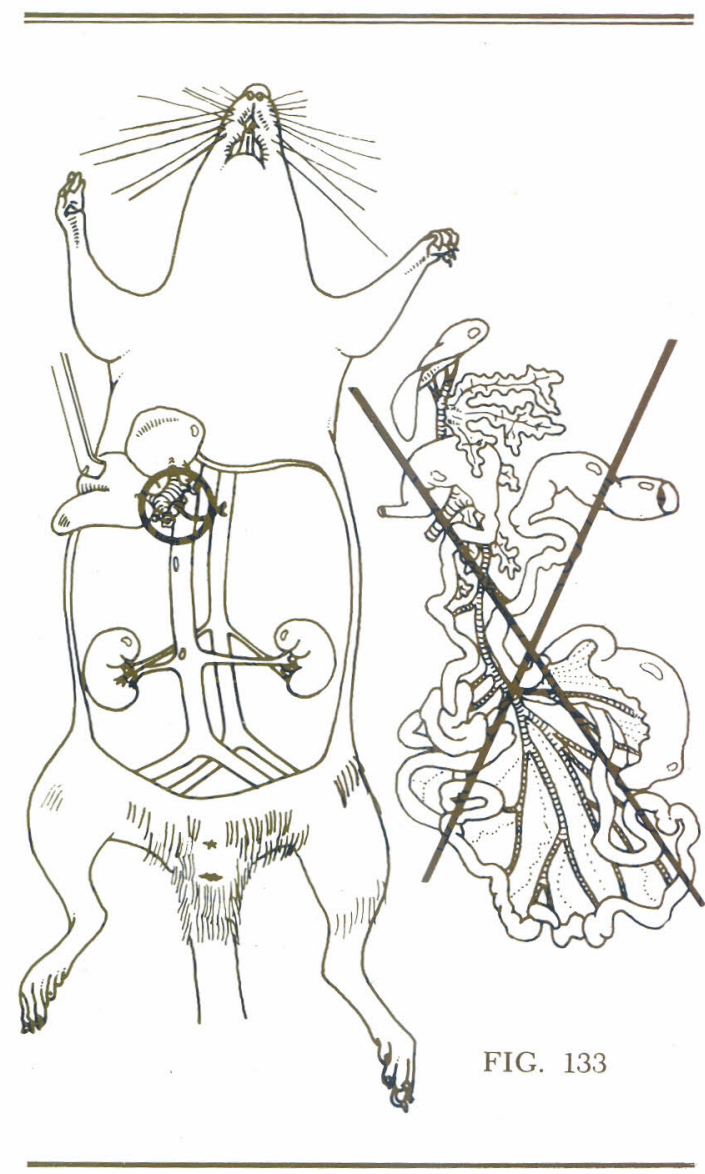


EFEITOS NA RELAÇÃO ENTRE FÍGADO E INSULINA

\section{1 \\ INTRODUÇÃO}

O estudo dos efeitos determinados pela $\mathrm{FE}$ no fígado definiu a insulina como o fator hepatotrófico mais importante do sangue portal. A interrupção do aporte direto do hormônio às células hepáticas causa alterações morfológicas, funcionais e da capacidade de regeneração.

A insulina é um hormônio formado e armazenado nas células $\beta$ das ilhotas de Langerhans do pâncreas. É secretada em resposta a grande variedade de estímulos. Estes incluem os combustíveis metabólicos (glicose, aminoácidos), diversos hormônios peptídicos (gastrina, secretina, pancreozimina e glucagon) e estímulos $\beta$-adrenérgicos 231 .

Em indivíduos normais, os níveis plasmáticos de insulina oscilam ao redor de $20 \mu \mathrm{U} / \mathrm{ml}$ de plasma e aumentam de 50 a $150 \mu \mathrm{U} / \mathrm{ml}$ após ingestão de glicose ${ }^{79}$.

A insulina circula como monômero livre. É rapidamente metabolizada no fígado e rim, com vida média de cerca de cinco minutos ${ }^{852}$. Atua principalmente nos músculos cardíaco e esquelético, tecido adiposo e fígado. Age no armazenamento e metabolismo dos lípides, proteínas e carboidratos. Age também nos processos anabólicos.

Serão apresentádas informações sobre a ação metabólica recíproca exercida, em condições normais, entre os hepatócitos e a insulina.

AÇÃO DA INSULINA NO METABOLISMO DAS CÉLULAS HEPÁTICAS

Metabolismo dos carboidratos

A glicose atravessa livremente a membrana dos hepatócitos sem a participação da insulina. No interior das células, o hormônio aumenta a velocidade de glicogênese e glicólise. Diminui a gliconeogênese principalmente nas etapas de transformação de aminoácidos e lactato para piruvato e de fosfoenolpiruvato para glicose-6-fosfato. Reduz a formação de AMP cíclico. Acredita-se que a insulina diminuiria também a velocidade da reação de transformação de glicose-6fosfato para glicose. A redução ou a falta de hormônio no plasma determina aumento da velocidade de gliconeogênese e reduz os depósitos de glicogênio ${ }^{79}$.

\section{$2 B$ \\ Metabolismo dos lípides}

A insulina aumenta a velocidade de conversão da glicose em ácidos graxos através da via glicolítica, com formação de acetil-Co. A. Desta forma diminui a glicose intracelular. Assim, uma quantidade adicional de glicose penetra nos hepatócitos. Aumenta, ao mesmo tempo, a síntese de gorduras inibindo a liberação de ácidos graxos livres ${ }^{79}$.

\section{$2 \mathrm{C}$ \\ Metabolismo das proteinas}

A elevação da taxa de alguns aminoácidos (por infusão ou ingestão) age diretamente aumentando a secreção de insulina. Apresentam, portanto, sinergismo com a glicose.

A insulina favorece a entrada de aminoácidos através da membrana celular. $\mathrm{O}$ transporte não depende da síntese protéica, que, no entanto, é também estimulada pelo hormônio ${ }^{79}$.

Nos ribossomos de animais diabéticos, demonstrou-se diminuição da síntese protéica ${ }^{33}$. O efeito foi evitado pela administração de insulina exógena ${ }^{890}$. Estas informações podem ser relacionadas com a influência que a insulina exerce nos ribossomos das fibras musculares. Da mesma forma, deve-se comentar a redu- 
ção evidente referida no retículo endoplasmático das células hepáticas, após a realização de APC em uma criança com fígado aparentemente normal ${ }^{764}$.

Acredita-se que a insulina poderia estimular a formação de uma proteína reguladora, específica, necessária para uma resposta eficiente dos ribossomos ao ARN mensageiro.

\section{3 \\ AÇÃO DO FÍGADO NO METABOLISMO \\ DA INSULINA}

A localização do fígado faz com que as células hepáticas entrem em contato com a insulina antes de sua chegada na circulação sistêmica. A produção do hormônio sofre a influência das concentrações periféricas de glicose e de certos aminoáci$\mathrm{dos}^{838}$. É parcialmente removido ao passar pelos sinusóides. Explica-se, assim, sua concentração duas vezes mais alta no sangue portal do que no sangue periférico. Blackard e Nelson ${ }^{68}$ estudaram doze pacientes não diabéticos com fígado normal. Verificaram que a taxa de insulina na veia porta era 36,9 $\pm 4,4 \mu \mathrm{U} / \mathrm{ml}$ e no sangue periférico de $16 \pm 9 \mu \mathrm{U} / \mathrm{ml}$. A extração de aproximadamente $50 \%$ numa única passagem pelo fígado foi confirmada no homem ${ }^{677}$, no cão ${ }^{838}$ e no fígado isolado de ratos ${ }^{506-507}$. A extração não é afetada pelos níveis de glicose do sangue portal, mas depende da sua concentração de insulina ${ }^{838}$. Parece ser conseqüente a um procésso físico-químico com pequeno gasto de energia ${ }^{519}$.

Aceita-se que a remoção da insulina, na passagem pelo fígado, seja devido à degradação e fixação, ambos processos independentes. Desconhece-se quais as quantidades do hormônio removidas por cada um deles ${ }^{245}$.

Os dois processos não interferem na produção de insulina pelo pâncreas, mas modificam e provavelmente regulam a concentração periférica ${ }^{891}$. Em perfusões de fígado isolado de rato, demonstrou-se que o clareamento da insulina ocorre em duas fases. A inicial é mais rápida e fugaz, enquanto que a outra é mais lenta, porém persistente ${ }^{507}$. A primeira fase foi relacionada com o processo de fixação e a segunda com o processo de degradação. Nessas experiências, o clareamento foi proporcional à concentração de oferta até um limite de $500 \mu \mathrm{U} / \mathrm{ml}$. Acima desses valores verificou-se saturação do sistema ${ }^{507}$.

\section{$3 \mathrm{~A}$ \\ Degradação da insulina pelo fígado}

O processo de degradação foi descoberto por Mirsky e Broh-Kahn em $1949^{503}$, que estudaram o metabolismo da insulina "in vitro". Descreveram um sistema de natureza aparentemente enzimática, capaz de inativar o hormônio no fígado, rim e músculos de vários animais. Denominaram de insulinase a substância responsável pelo processo. Demonstraram, além disso, algumas particularidades que a distinguem de outras enzimas proteolíticas.

Mais tarde, o processo de degradação foi estudado “in vivo" 374-763 em perfusões de fígado isolado ${ }^{778}$ e em vários componentes celulares ${ }^{262-503}$. Estes métodos confirmaram sempre a existência do processo e justificaram duas explicações sobre seu mecanismo. A degradação seria conseqüente:

- à ação do sistema insulinase proposto por Mirsky e Broh-Kahn ${ }^{503}$. Agiria degradando a molécula da insulina pela clivagem de ligações peptídicas. Esta hipótese foi corroborada pela intensa atividade de proteases em concentrados de membranas celulares ${ }^{262}$;

- à ação de uma enzima proteolítica isolada por Tomizawa ${ }^{817}$ em microssomos de fígado de boi. Denominou-a de insulina-trans-hidrogenase glutatiônica (ITG). Diferentemente da precedente, esta substância age rompendo as ligações dissulfeto da molécula da insulina. 
Admite-se que exerça ação reguladora acessória da insulinemia. A concentração da ITG diminui, paralelamente à redução de insulina, em ratos em jejum e com diabete induzida por aloxane ${ }^{827}$. Pelo contrário, a concentração da enzima aumentou após a realimentação de animais normais, mantidos previamente em jejum prolongado. Aumentou também em animais diabéticos tratados com insulina ${ }^{827}$.

Parece que a produção de ITG é regulada também por outros fatores como, por exemplo, pelo glucagon que inibe sua ação "in vitro"817. Mais recentemente referiu-se $\mathrm{e}^{827}$ que a própria insulina pode estimular a produção de ITG. Esse estímulo seria intermediado pelo ARN na síntese dos precursores protéicos da enzima. O sistema auto-regulador concorreria para a manutenção das taxas normais de insulina valorizando a participação do fígado em mais este processo da homeostase.

\section{$3 B$}

Fixação da insulina pelo fígado

Nos últimos anos, esclareceram-se aspectos do mecanismo com que agem os hormônios polipeptídicos em geral. A primeira fase é representada pela fixação do hormônio em regiões específicas das células do órgão alvo, denominadas "local receptor”. Tem merecido especial atenção a localização precisa dos receptores nas células alvo. Aceita-se que predominam na membrana celular. Mais recentemente, foram localizados também no aparelho de Golgi ${ }^{60}$.

Os conhecimentos sobre a questão foram obtidos em células íntegras ou em organelas isoladas por ultracentrifugação. Empregaram-se células do tecido adiposo $^{264272}$, linfócitos e fibroblastos ${ }^{280} 306$, membranas purificadas ${ }^{263}$ frações de células adiposas e hepáticas 163164 .

Os dados que mais contribuíram para o esclarecimento da fixação da insulina pelas células hepáticas foram obtidos em membranas plasmáticas de tecido hepático de vários animais, inclusive do homem ${ }^{550}$.

Os resultados destas experiências permitiram várias conclusões. Para sua aceitação, porém, deve-se ter em mente pelo menos:

- que nem todas as células isoladas são hepatócitos;

- que é inevitável uma alteração da membrana celular durante o processo de ultracentrifugação; e

- que merece restrições a extrapolação destas informações para as condições "in vivo".

Feitas estas ressalvas, podem ser citados os seguintes aspectos gerais do problema:

- parte da atividade do hormônio nas células hepáticas parece dependente da sua fixação em receptores ${ }^{664}$;

- a insulina, como os outros hormônios polipeptídicos, age principalmente na membrana celular 263 .

- a fixação da insulina depende da sua concentração, da concentração dos receptores e da temperatura ${ }^{664}$;

— o número de receptores por célula, sua afinidade pelo hormônio e a velocidade de fixação variam com as espécies e com as doenças ${ }^{664}$;

- a fixação nos receptores e a degradação da insulina são processos independentes, ainda que possam ocorrer na mesma estrutura subcelular ${ }^{827}$. Entretanto, nem sempre é possível separá-los por métodos experimentais;

- o processo de fixação é reversí-
vel506;

- enquanto unida ao receptor, a insulina parece não ser degradada ${ }^{262}$. Isto explica que ao se desligar dos receptores pode retornar intata à circulação ${ }^{279-593}$;

- substâncias análogas podem competir com a insulina pela fixação nos receptores na membrana celular. Quanto mais próxima da insulina for a atividade biológica das substâncias análogas “in 
vitro", tanto maior será a capacidade de competição ${ }^{397}$. Dentre estas, as mais importantes são a pré-insulina e a somatomedina ${ }^{664}$.

Acredita-se que a persistência de taxas plasmáticas elevadas de insulina determine aumento proporcional de receptores nas membranas celulares. Desta forma, existiria mais um mecanismo protetor contra a elevação de insulina no sangue periférico ${ }^{827}$. Pode ocorrer exaustão da capacidade da membrana celular em produzir receptores adicionais se a hiperinsulinemia for exageradamente elevada ou prolongada. A elevação primária e prolongada do hormônio poderia, assim, preceder e explicar alguns dos estados de resistência à insulina. Assim, curiosamente, a própria insulina seria um dos seus antagonistas ${ }^{281}$.

Alterações do metabolismo da insulina em pacientes com hepatopatia crônica

É do conhecimento geral que pacientes cirróticos mostram freqüentemente curva glicêmica alterada ${ }^{141}$. Alguns autores referem que um terço dos pacientes apresentam diabete bem caracterizada e cerca da metade, traçado anormal do teste de tolerância à glicose $\mathrm{e}^{497}$. Verificam-se alterações mais evidentes nas fases descompensadas das doenças hepáticas. Observa-se maior redução do coeficiente de assimilação periférica de glicose e taxas basais de insulina mais elevadas $^{141}$
Porém, a severidade e o grau de atividade da doença hepática, definidos segundo critérios clínicos e patológicos, não puderam ser correlacionados com as taxas de insulina. Alguns autores referem valores nitidamente anormais em pacientes com hepatopatia leve $\mathrm{e}^{141}$.

Qualquer que seja a causa de tais fenômenos, prevalece a opinião de $\mathrm{Me}$ gyesi e col.497, segundo a qual na doença hepática crônica existe uma resistência à insulina. Esta é sugerida pelo desaparecimento lento da glicose associado a taxas elevadas do hormônio na circulação ${ }^{141}$.

Foram sugeridas outras causas, como diminuição da reserva de glicogênio no fígado doente, já demonstrada histoquimicamente ${ }^{443}$. Outros acreditam na redução da atividade periférica da insulina semelhante à observada nos obesos. Desta forma, a doença hepática constitui-se em verdadeiro estado prédiabético ${ }^{702}$.

Na realidade, como já referido na espécie humana, o fígado possui capacidade de fixar e degradar insulina. A elevação da sua concentração em pacientes com doença hepática crônica poderia indicar diminuição dos dois processos. O uso praticamente universal de radioimunensaio para a dosagem da insulina permite uma hipótese adicional. Nas doenças hepáticas, poderíamos estar diante de uma condição paradoxal representada por uma forma de hormônio imunologicamente ativo mas biologicamente inerte $^{141}$. 


\section{Efeitos da chegada direta do sangue portal na circulação sistemica}

A FE desvia o sangue portal diretamente para a veia cava inferior. As substâncias absorvidas no intestino e os hormônios produzidos no território portal atingem a circulação sistêmica sem a elaboração metabólica normalmente realizada pelas células hepáticas. A alteração hemodinâmica determina vários efeitos sistêmicos. Destacam-se os neuropsíquicos, pela gravidade, pela freqüência com que ocorrem e pela riqueza de informações disponíveis.

Dividimos, por isso, em duas partes a revisão bibliográfica. A primeira dedicada exclusivamente aos efeitos neurológicos e a segunda aos demais.

\section{EFEITOS NEUROLÓGICOS \\ DESCRIÇÃO}

Pesquisadores do grupo de Pavlov ${ }^{326}$, já em 1893, observaram, em cães com FE, uma síndrome neurológica por eles denominada "intoxicação pela carne". Estudaram sessenta animais e descreveram de maneira pormenorizada uma seqüência de sinais iniciada, geralmente, entre dez e trinta dias após a cirurgia. A síndrome tinha início com modificação do comportamento durante períodos mais ou menos prolongados, caracterizada por atitudes agressivas em animais

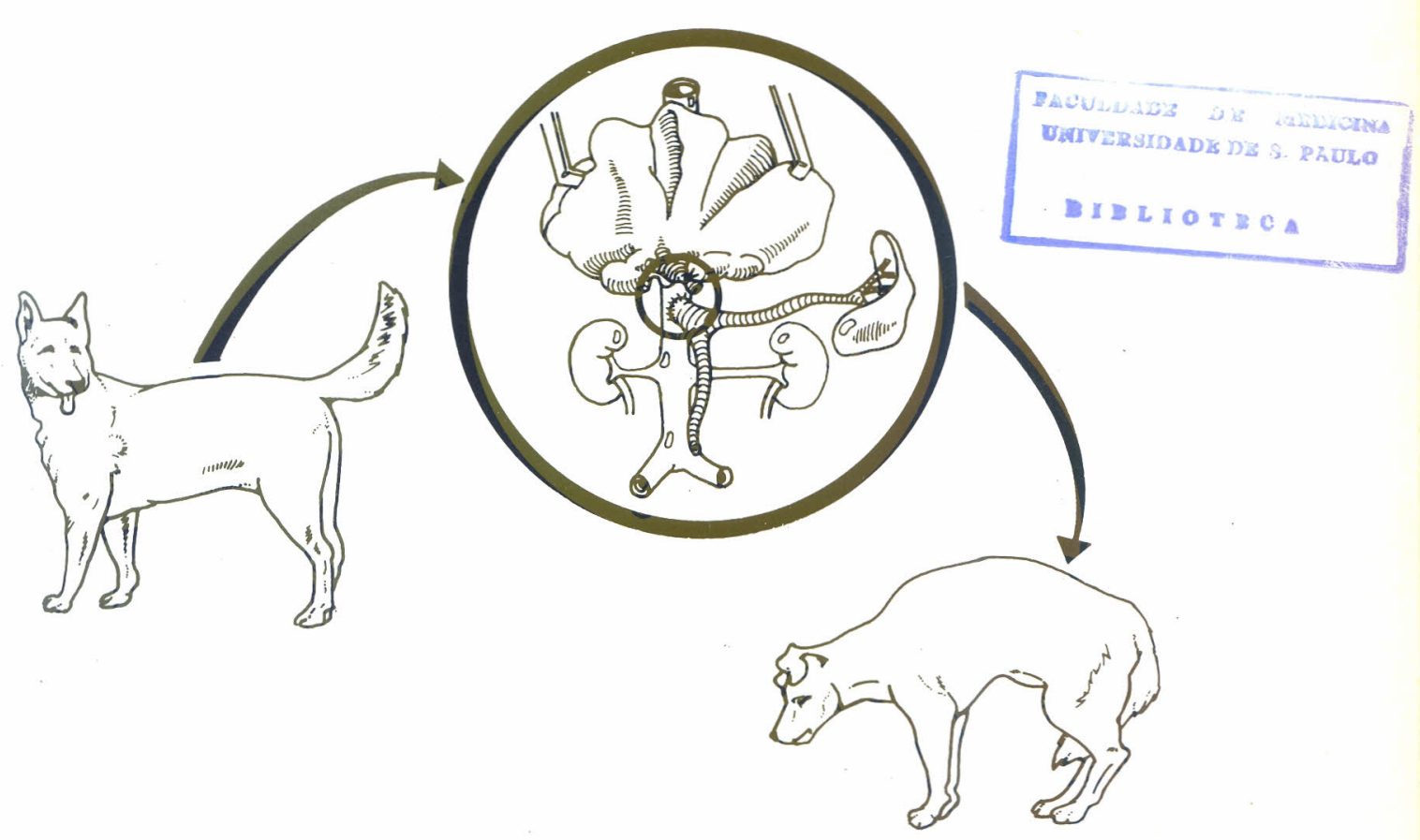

FIG. $134 *$ 
antes dóceis e obedientes. Agitados na gaiola, mordendo qualquer objeto acessível, os cães mostravam ritmo respiratório acelerado e convulsões freqüentes. A excitação era precedida ou seguida por fases de apatia, fraqueza e mesmo por estado comatoso (Fig. 134 ). Com o decorrer do tempo verificaram ataxia, perda de visão e insensibilidade a estímulos dolorosos.

Após seis a oito meses, apareciam períodos de coma profundo e convulsões, que tanto podiam evoluir para a morte quanto para a recuperação completa.

O quadro neurológico pode-se apresentar no homem sob suas formas principais:

- EPS: caracterizada por alternância de períodos de agressividade com outros de letargia, diminuição da acuidade sensorial, redução da capacidade intelectual, perda do discernimento, alteração de conduta moral, associada ou não a hipotermia e hiperventilação intermitente. Nota-se, sob o aspecto neuromuscular, hiper-reflexia, sinal de Babinsky e asterixis. Periodicamente, e em conseqüência de fatores desencadeantes, sonolência, estupor e coma com desaparecimento dos reflexos profundos e do asterixis. Raramente convulsões, rigidez descerebrada e perda do reflexo corneano. $\mathrm{Na}$ maioria das vezes, o quadro não atinge esta intensidade, sendo reversível sem seqüelas. As alterações anatomopatológicas correspondentes são representadas por aumento dos astrócitos.

- Degeneração hepatocerebral adquirida: caracterizada por quadro clínico semelhante ao acima descrito, acrescido de demência, facies inexpressiva, disartria, corioatetose e ataxia. No exame histológico demonstra-se, além da astrocitose, degeneração neuronal e desmielinização acentuadas.

Discute-se a inter-relação entre as duas formas, aceitando alguns ${ }^{91}$ que a segunda representa a fase final da primeira.

\section{ETIOLOGIA DAS ALTERAÇOEES NEUROLÓGICAS}

Freqüentemente é difícil distinguir qual a contribuição etiológica do desvio do sangue portal e qual a da insuficiência hepática concomitante. Os seguintes aspectos devem ser considerados:

- a insuficiência hepática grave causa sintomas neuropsíquicos muito semelhantes à EPS;

- a APC no homem é realizada como tratamento da hipertensão portal conseqüente a moléstias que provocam, paralelamente, maior ou menor diminuição da reserva funcional hepática;

- a FE causa alterações morfológicas e funcionais hepatocelulares capazes de agravar ou ocasionar uma condição de insuficiência hepática;

- na hipertensão portal forma-se circulação colateral pela qual o sangue portal é desviado para a circulação sistêmica. Assim sendo, muitas vezes a FE apenas aumenta uma alteração hemodinâmica preexistente;

- aceita-se que ocorra um círculo vicioso entre a FE e a redução funcional através dos efeitos tróficos que o desvio do sangue portal exerce nos hepatócitos. De fato, após sete meses de FE em cães, notou-se diminuição do peso do fígado, em média, de 900 para $350 g^{185}$. No homem, após 22 meses da operação, faz-se menção à redução do peso calculado do fígado de $1.200 \mathrm{~g}$ para apenas $700 \mathrm{~g}^{493}$.

No entanto, o quadro neuropsíquico apresenta peculiaridades diferentes nos pacientes com função hepática preservada e $A P C$, de um lado, e naqueles com insuficiência hepática progressiva'e não operados, de outro.

Nos casos já submetidos a cirurgia, o quadro se manifesta de início súbito e geralmente à noite. Evolui a partir de um estado de confusão mental rapidamente para um estado de estupor e coma. Superada a crise, o paciente volta a apresentar 

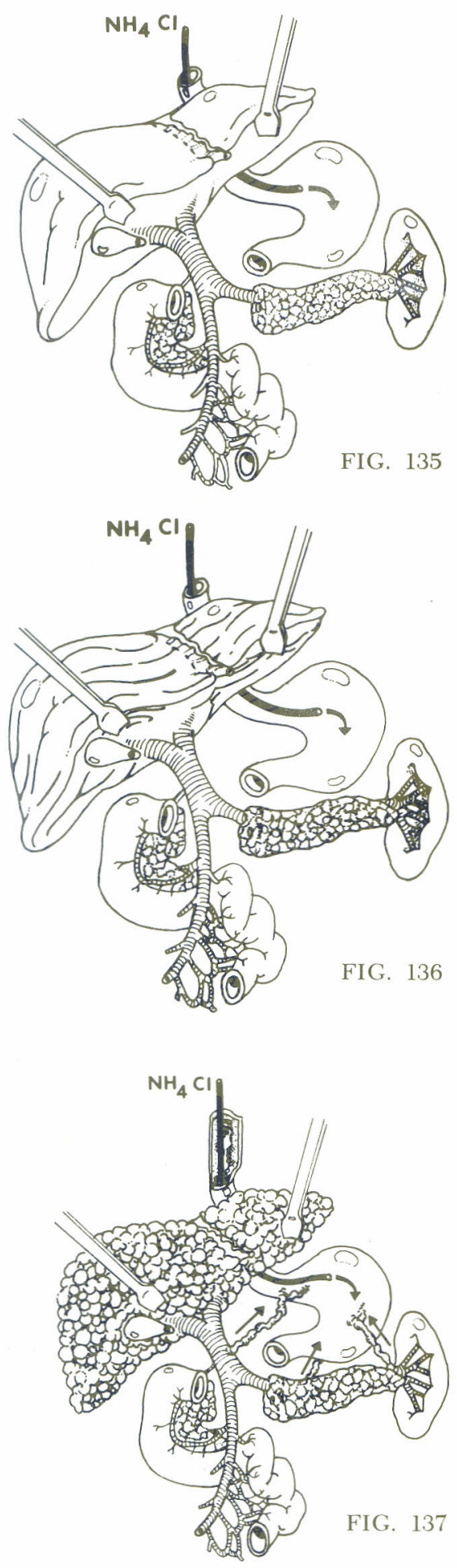

condições neuropsíquicas normais, muitas vezes com amnésia do episódio recente e na maioria dos casos, os pacientes levam vida normal até aparecimento de novo episódio. Ao contrário, nos pacientes não operados o quadro neuropsíquico caracteriza-se por progressiva queda da percepção sensorial, alteração da personalidade e comportamento inesperado. Uma vez iniciada, a condição clínica apresenta evolução subcrônica, progressiva, e irreversível. É intercalada por episódios agudos de confusão com ou sem alucinações, delírio e coma ${ }^{802}$.

Além disso, estudos experimentais e observações de casos clínicos especiais facilitam a compreensão do problema.

Desde já,é necessário considerar que, em base de fatos analisados mais adiante, a elevação da taxa de amônia circulante foi sempre relacionada com o quadro neurológico. Por conseguinte, muitas das informações sobre a síndrome neuropsíquica dizem respeito às taxas de amônia no sangue periférico.

A importância da chegada direta do sangue portal à circulação sistêmica foi valorizada, já em 1932, por Van Caulaert e Deviller ${ }^{825}$. Administraram sobrecarga oral de cloreto de amônio a indivíduos normais (Fig. 135), a pacientes com hepatite aguda (Fig. 136) e a cirróticos (Fig. 137). Não verificaram elevação da amoniemia nos dois primeiros grupos, contrariamente ao observado em todos os cirróticos. Considerando que a insuficiência hepática da hepatite por vírus era igual ou mesmo maior do que a dos cirróticos, concluíram que a hiperamoniemia era conseqüente ao desvio do sangue portal pela circulação colateral neoformada e não pela insuficiência hepatocelular.

O problema foi abordado experimentalmente por Monguió e Krause, em $1934^{508}$, e logo depois por Kirk ${ }^{411}$. Valorizaram o desvio do sangue portal em detrimento da insuficiência hepática. Demonstraram que a mesma sobrecarga de 


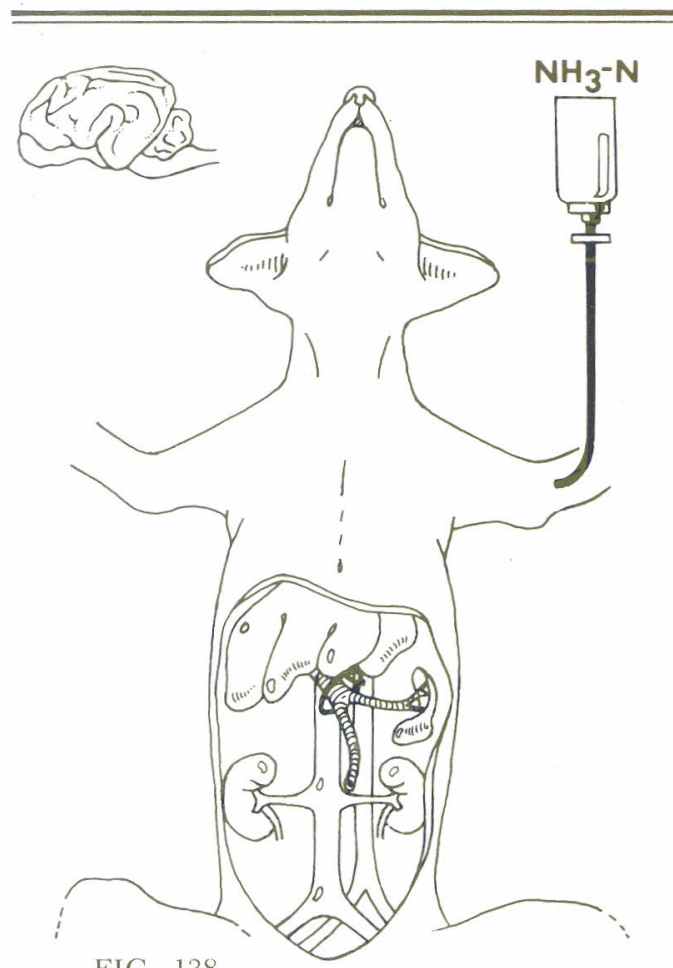

FIG, 138
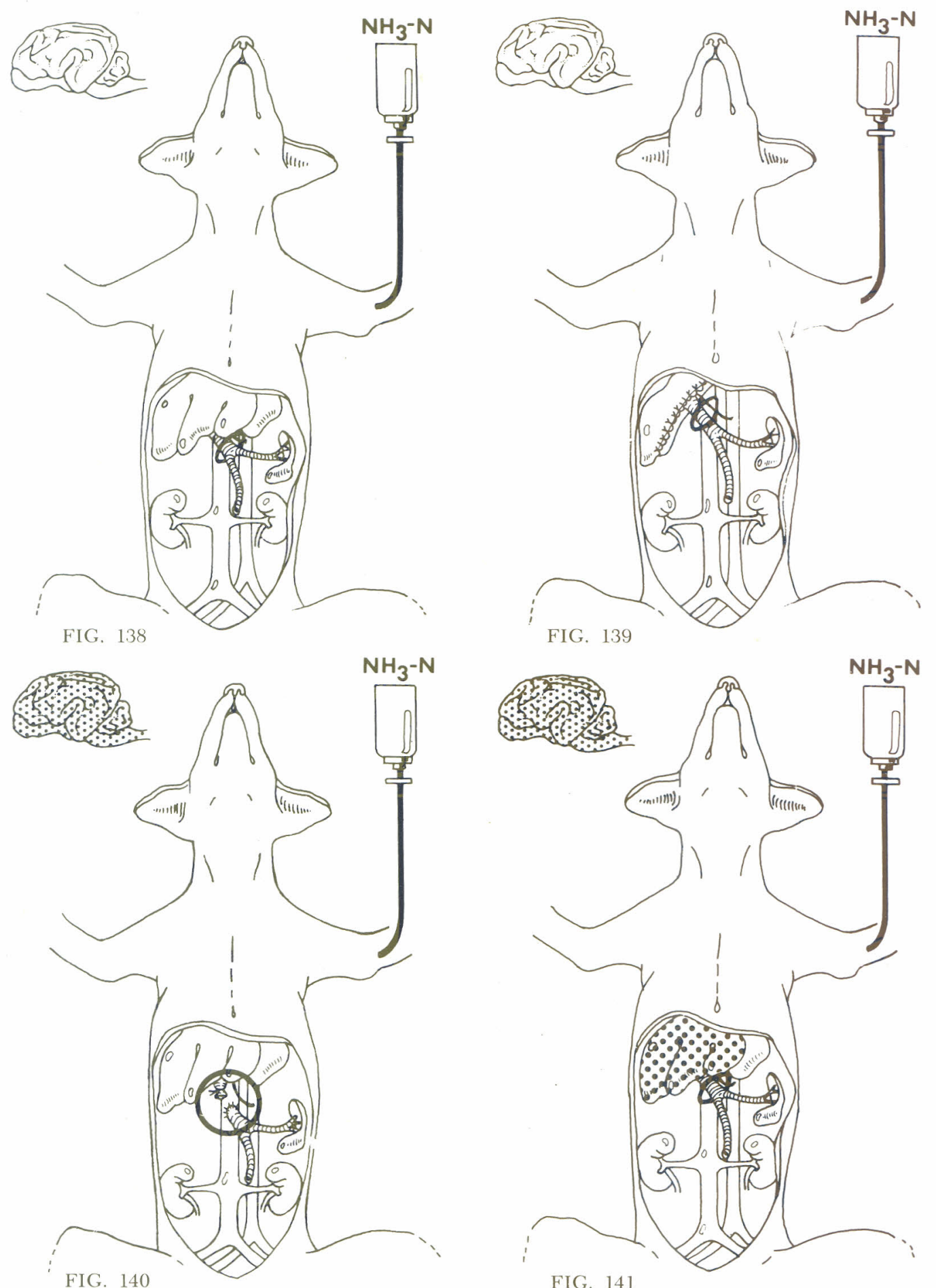

FIG. 141 
amônia em animais controles (Fig. 138) ou com prévia ressecção de $80 \%$ do fígado (Fig. 139) não provocava os sintomas neurológicos. Pelo contrário, a mesma administração determinou a síndrome em animais com $\mathrm{FE}$ e fígado normal (Fig. 140). Tais observações foram confirmadas mais tarde, em cães, por Drapanas e col., em 1955208. Constataram ser necessário necrose isquêmica de pelo menos 90\% do parênquima (Fig. 141) para causar o quadro.

Analisando-se os efeitos da FE em pacientes com fígado normal ou com lesões hepáticas muito leves, obteve-se a primeira comprovação clínica da importância do desvio em si. ${ }^{358-493}$. Pela elegância da metodologia empregada, destacam-se as observações de McDermott e Adams, em 1954493. Estudaram um paciente de 69 anos com desvio de sangue portal e fígado normal. Realizaram AMC durante a pancreato-duodenectomia para extirpação de um carcinoma da cabeça do pâncreas, que infiltrava o segmento retropancreático da veia porta (Fig. 142). O paciente apresentou episódios repetidos de EPS e coma durante os treze meses de pós-operatório que permaneceu internado. Sua função hepática era praticamente normal, como comprovado por repetidas avaliações bioquímicas.

Raia, S. e col. ${ }^{612}$ verificaram, também no homem, que a ressecção de até $87 \%$ do parênquima não causou quadro neurológico, desde que todo o sangue portal perfundisse o fígado remanescente (Fig. 143).

A participação da FE na etiologia da síndrome neurológica foi reforçada ainda mais por Orloff e col., em. 1963559. Em cães submetidos a FE de diferentes tamanhos (Figs. 144-145), demonstraram relação direta entre o diâmetro da anastomose e as taxas de amônia sanguínea. Demonstraram que a elevação da amônia periférica era proporcional ao fluxo através da anastomose.

Pela mesma razão, merece ser citado o

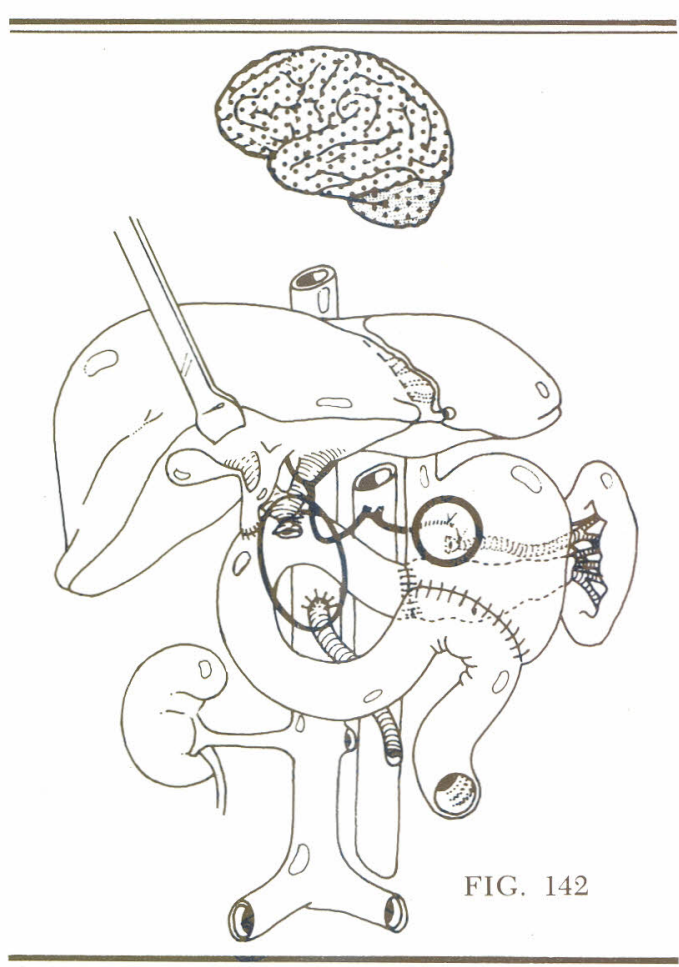

caso referido por Kakos e col., em 1973398. Em um cirrótico com APC e EPS grave, os sintomas neurológicos desapareceram pela oclusão deliberada da anastomose. A ingestão diária de $70 \mathrm{~g}$ de proteínas não provocava os sintomas que surgiam antes da reoperação com dieta

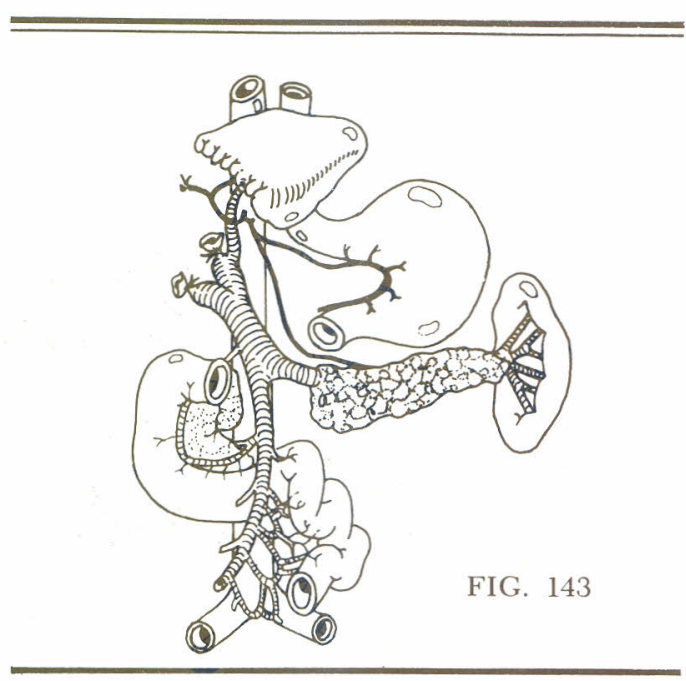



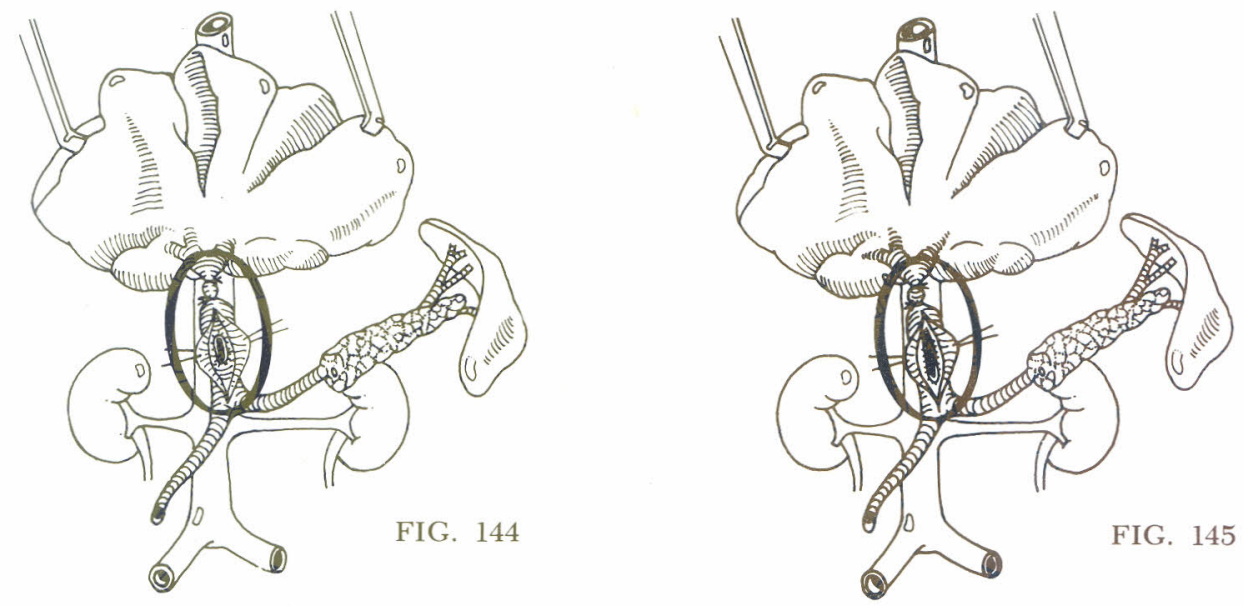

de $20 \mathrm{~g}$. O grau de insuficiência hepática permaneceu provavelmente inalterado antes e depois da correção cirúrgica.

Recentemente Raia, S.* obteve resultados semelhantes desfazendo, respectivamente, uma AER e uma APCLL, em dois EHE.

Estes conhecimentos explicam a alta incidência de EPS observada em EHE com APC, praticamente igual à verificada em cirróticos ${ }^{739}$. Se a etiologia da síndrome dependesse da reserva funcional hepática e não do desvio do sangue portal para a circulação sistêmica, a incidência deveria ser muito menor nos primeiros cuja função hepática apresenta-se pouco alterada.

Uma vez estabelecido que na maioria dos casos a EPS deve-se principalmente ao desvio do sangue portal para a veia cava e não à insuficiência hepática pregressa ou decorrente, devemos analisar:

- quais os agentes "tóxicos" cerebrais que determinam o quadro neurológico;

- por que as taxas sanguíneas de tais substâncias permanecem elevadas;

- qual o mecanismo fisiopatológico das alterações neurológicas;

- por que a EPS não ocorre em todos os animais ou pacientes submetidos à FE.

\section{$2 A$ \\ Agentes "tóxicos" responsáveis pelo quadro neurológico}

A facilidade e a rapidez com que o quadro neurológico aparece e regride sugerem etiologia metabólica, aceita pelos autores desde as primeiras observações em cães com $\mathrm{FE}^{326}$. A partir de então, foram identificadas várias substâncias capazes de agir no sistema nervoso central. Destaca-se a amônia pela quantidade de observações e provas disponíveis. No entanto, existem dados suficientes para admitir que outras substâncias também exercem papel importante na etiologia da $\mathrm{EPS}^{247}$ justificando a revisão em dois tópicos. No primeiro, será analisada a amônia e no segundo as outras substâncias.

Amônia

A importância da amônia constitui um dos poucos aspectos do problema aceito sem discussão na etiopatogenia da EPS. A uniformidade de opiniōes deve-se ao grande número de informações diretas ou indiretas. Para melhor compreensão, serão relacionadas numa seqüência nem 
sempre cronológica:

A denominação "intoxicação pela carne" foi usada pelos autores que pela primeira vez descreveram a síndrome em animais $^{326}$. Surgiu da observação de que o aparecimento dos sintomas neurológicos dependia nitidamente do tipo de alimentação. O quadro surgia com maior intensidade nos cães que ingeriam grande quantidade de carne. Citam o exemplo de um cão com FE pérvia que durante 48 dias de pós-operatório recebeu apenas pão e leite. Não mostrou outros sinais além da perda de apetite. Forneceram-lhe então 120 g de pó de carne dissolvido em leite. No dia seguinte, $100 \mathrm{~g}$ da mesma dieta. Na tarde do segundo dia, verificaram sonolência seguida de excitação, verdadeiro estado furioso e perda de visão. O retorno à dieta habitual permitiu recuperação integral em três dias. Depois da regressão dos sintomas, administraram $150 \mathrm{~g}$ de pó de carne e leite, em 24 horas, e 120 g no dia seguinte. Houve nova fase de excitação, seguida de coma e óbito. Relataram que este exemplo representava o comportamento habitual dos sessenta animais com FE estudados e concluíram, pela primeira vez, que o desvio do sangue portal causava uma limitação de tolerância à carne, capaz de provocar graves sintomas e, freqüentemente, morte.

A possibilidade de desencadear a síndrome em animais com FE pela administração de refeições hiperprotéicas foi confirmada mais tarde por Hawk, em 1908341. Demonstraram que nem todos os animais com FE apresentavam quadro neurológico desde que recebes:em alimentação padronizada. Porém, se a ela se adicionasse extrato de carne, todos entravam em coma.

A primeira relação entre ingestão de proteínas, produção de amônia e EPS, foi feita por De Filippi ${ }^{178}$ já em 1899. Mais tarde, atribuíram-se os sintomas neurológicos à incapacidade do fígado de transformar a amônia em uréia através do ciclo da ornitina, em condições normais, processo várias vezes provado experimentalmente 209 .

Desde 1912257, sabe-se que bactérias do intestino degradam substâncias nitrogenadas, como aminoácidos e uréia, produzindo amônia que após um processo de absorção passiva chega ao fígado pelo sangue portal.

A importância do tubo digestivo na etiologia da EPS foi caracterizada por uma série de observações. Bollman e Mann, em $1936^{78}$, certificaram-se de que os sintomas ocorriam com mais intensidade após períodos de obstipação e que desapareciam com o uso de laxantes. Mais tarde, Lawrence e col. observaram, em 1958422, que os efeitos neurológicos da hepatectomia total, em cães, podiam ser evitados pela ressecção concomitante do tubo digestivo. Paralelamente, Drapanas e col., em 1955 208 , demonstraram comportamento semelhante em cães com fígado desvascularizado. Reynolds e Wilson, em $1961^{644}$, sugeriram ser o colo direito a sede da absorção dos agentes "tóxicos". Apontaram ausência de sintomas num paciente com $\mathrm{AMC}$ e ressecção daquele segmento de tubo digestivo. Foram obtidos bons resultados também com lavagens intestinais repetidas, ingestão de antibióticos não absorvíveis, administração oral de inibidores da urea$\mathrm{se}^{887}$, alterações do $\mathrm{pH}$ intestinal ${ }^{115} \mathrm{e}$ exclusão do intestino grosso ${ }^{635}$. Pelo contrário, verificou-se que o quadro neurológico pode ser causado pela chegada, ao intestino, de substâncias capazes de aumentar a produção de amônia. Refere-se sangue conseqüente a hemorragias digestivas $^{863}$ e uréia proveniente de ureterosigmoidostomias ${ }^{41-518}$.

Descreveu-se quadro muito semelhante à EPS e coma em crianças com fígado normal e hiperamoniemia devido a vários defeitos hereditários do ciclo da uréia. Menciona-se, como exemplo, a deficiência de ornitina-carbamil-transferas $e^{521-722}$. 
Vários autores referem ter notado uma relação p aticamente constante entre a sintomatolo ia neurológica e as taxas sanguíneas de amônia, desde que duas vezes superiores ao valor normal 170-493-581-648.

Foram encontrados no líquido cefalorraquidiano de pacientes com EPS níveis elevados da glutamina, produto final da detoxicação cerebral da amônia ${ }^{103-286-357}$.

McDermott e Adams ${ }^{493}$, estudando minuciosamente um caso com $\mathrm{FE}$ e fígado normal, provocaram, deliberadamente, quadros clínico e eletrencefalográfico típicos de EPS. Administraram sobrecarga oral de proteínas ou amônia. Notaram também que a sintomatologia e os sinais neurológicos ocorriam paralelamente a uma elevação das taxas sanguíneas de amônia.

Contudo, apesar de todos esses dados apontando a hiperamoniemia como um dos agentes etiológicos da EPS, persistem dúvidas, baseadas nas seguintes observações $^{840}$ :

- em alguns pacientes, falta uma correlação nítida entre o grau das alterações neurológicas e os níveis da amoniemia sanguínea;

- para induzir a síndrome em animais, são necessárias taxas muito mais elevadas do que as verificadas nos pacientes em coma;

-- a administração aguda de amônia em hepatopatas não induz constantemente à síndrome neurológica.

Essas dúvidas devem, porém, ser avaliadas considerando os seguintes fatos:

- a taxa de amônia sanguínea pode não refletir a concentração intracerebral dessa substância. Realmente, no coma hipoglicêmico, por exemplo, pode-se verificarcoexistência de glicemia normal e estado comatoso. Aceita-se que os efeitos neurológicos persistem após a interrupção da agressão metabólica;

- os pacientes com EPS apresentam hiperamoniemia crônica, cujos efeitos podem ser diferentes da hiperamoniemia aguda, mesmo mais elevada;
- os métodos habitualmente utilizados para a dosagem de amônia avaliam a quantidade total representada pela soma da forma ionizada e da não ionizada. A conversão de uma para outra depende do pH. Taxas elevadas podem não corresponder à quantidade efetiva da forma não ionizada. Admite-se que esta seja mais tóxica pela maior facilidade com que penetra a membrana celular.

Outras substâncias

Ácidos graxos de cadeia curta (butírico, valérico e octanóico) têm sido apontados como agentes etiológicos do coma hepático. Observaram-se taxas elevadas dessas substâncias no sangue e no líquido cefalorraquidiano de pacientes com EPS grave $^{127}$.Aingestão de grandes doses dessas substâncias determina, em animais, aparecimento de estado comatoso reversível, com alterações eletrencefalográficas semelhantes à EPS.

Taxas de aminoácidos, como metionina e alguns dos seus derivados, podem estar elevadas em pacientes em coma hepático ${ }^{580}$. Administração oral de metionina pode causar sintomatologia neurológica em pacientes com moléstia hepática . Experimentalmente, alguns dos seus derivados provocam os mesmos efeitos em animais. Todavia, os efeitos tóxicos da ingestão oral de metionina acompanham-se de elevação da amônia sanguínea e podem ser evitados pela administração oral concomitante de antibióticos e não ocorrem quando a substância é administrada por via endovenosa. Estas observações sugerem que os efeitos tóxicos da metionina e derivados ocorram pela ação bacteriana intestinal, capaz de transformá-los em amônia.

São também interessantes, as observações mais recentes de que o plasma de ratos, cães e pacientes com EPS apresentam uma alteração de aminoácidos muito semelhante. Surgiram assim hipóteses relacionando a concentração 
plasmática de aminoácidos com a etiologia da EPS. Nos portadores de EPS, a modificação no aminograma inclui aumento de fenilalanina, metionina e tirosina simultaneamente a uma redução de valina, leucina e isoleucina. Estes aminoácidos competem com aqueles aromáticos no transporte através da barreira hemoliquórica ${ }^{250}$. Esta redução justificase em base dos resultados de várias experiências laboratoriais e algumas observações clínicas:

- a sobrevida de cães com FE é inversamente proporcional ao conteúdo de aminoácidos aromáticos na dieta administrada. A alimentação baseada com carne contém essas substâncias em níveis mais altos, predominando a fenilalanina, a tirosina e o triptofano ${ }^{143}$;

- observação análoga foi referida por Fenton e col. ${ }^{238}$, em pacientes com EPS, comparando sua tolerância à dieta de leite com outras ricas em carne;

- Bessman e Mirick ${ }^{64}$, em animais com insuficiência hepática, demonstraram que a administração de refeições de sangue provocava alterações mais evidentes que outras baseadas em caseína.

A escola de Fischer relacionou a nutrição parenteral habitual com o aparecimento de EPS em pacientes com insuficiência hepática grave ${ }^{250}$. Cães com FE, quando tratados com soluções convencionais de aminoácidos, evoluem para a morte como esperado após o desvio do sangue portal ${ }^{247}$. Em modelos semelhantes, conseguiram obter sobrevida de todos os animais com o uso de soluções balanceadas de aminoácidos. Em 1976, ampliaram estas observações, estudando onze pacientes em coma hepático e empregando a mesma solução balanceada. Mencionam resultados igualmente favoráveis e atribuem a evolução satisfatória à normalização dos níveis plasmáticos de aminoácidos ${ }^{249}$. Acreditam que a síntese de neurotransmissores centrais depende, pelo menos em parte, dos constituintes de plasma. Parece que a fenilalanina, a tirosina, o triptofano, a valina, a leucina e a isoleucina sejam aqueles que mais participam do processo $\mathrm{s}^{240-322}$.

A análise dessas observações sugere uma relação entre as taxas de aminoácidos plasmáticos e os sintomas da EPS, provavelmente através de uma ação na síntese de neurotransmissores centrais. A mesma escola de Fischer202-246-248 constatou, em pacientes com EPS, modificações nos neurotransmissores centrais, particularmente naqueles do sistema adrenérgico. As alterações referem-se, principalmente, a fenilalanina, octopamina e serotonina. Os efeitos cerebrais parecem não depender das modificações plasmáticas. Pelo menos para a octopamina, o efeito central parece preceder o aumento da taxa sanguínea ${ }^{14}$. Por outro lado, as aminas biogênicas, em condições normais, não atravessam a barreira hemoliquórica $^{247}$. Assim, a maioria dos autores atribui aqueles distúrbios dos neurotransmissores às concentrações de aminoácidos aromáticos no plasma e no cérebro ${ }^{240}$.

Aceita-se que as aminas biogênicas agem como neurotransmissores fracos. Seu acúmulo nos sinaptossomos interfere na transmissão normal dos impulsos, analogamente ao que acontece com os falsos neurotransmissores. Explica-se, assim, a regressão freqüente do quadro, pela ação da L-dopa, administrada a pacientes em coma hepático que atua provavelmente como precursora dos neurotransmissores normais ou desloca os falsos neurotransmissores dos sinaptossomos ${ }^{840}$.

As informações resumidas sobre os agentes "tóxicos" cerebrais permitem três conclusões básicas:

1 - provavelmente o quadro neurológico devido à $\mathrm{FE}$ é causado por fatores que somam seus efeitos na indução das alterações cerebrais;

2 - a importância relativa de cada um dos fatores responsáveis pela EPS varia de indivíduo para indivíduo, provavelmente conforme a sensibilidade do 
seu sistema nervoso central;

3 - nenhuma das substâncias citadas pode ser responsabilizada como causa única da EPS. Além disso, é possível que outras toxinas, ainda não identificadas, exerçam também papel etiológico importante. Refere-se a presença de uma substância dialisável, no líquido cefalorraquidiano de pacientes com EPS, capaz de induzir experimentalmente sintomas neurológicos semelhantes ${ }^{91}$.

\section{$2 B$}

Por que as taxas sanguineas dos agentes "tóxicos" permanecem elevadas

Do exposto, percebe-se que os agentes causadores da EPS provavelmente são substâncias absorvidas habitualmente no intestino. Representam componentes do sangue portal que atingem a circulação sistêmica antes de elaboração metabólica nos hepatócitos. Admite-se que a simples variação das concentrações de componentes normais do plasma pode contribuir como fator etiológico dos sintomas neuropsíquicos.

As alterações absolutas ou relativas dos componentes plasmáticos, em portadores de FE, são conseqüentes ao aumento da absorção intestinal, à chegada direta na circulação sistêmica e ao clareamento ineficaz na passagem pelo fígado através da artéria hepática.

\section{Aumento da absorção intestinal}

A FE aumenta a absorção de amônia e de outras substâncias em pacientes com hipertensão portal ${ }^{600}$. Este fato pode ser relacionado com a ação simultânea exercida por vários efeitos decorrentes do desvio do sangue portal para a veia cava inferior. Dentre eles destaca-se a elevação d i fluxo portal. De fato, o fluxo portal po rece duplicar em cirróticos, como observado em medidas com fluxômetro eletromagnético ${ }^{239-464}$ e com métodos indi- retos600. Paralelamente, parece que a descompressão portal provoca aumento da microcirculação intestinal facilitando, assim, a absorção passiva de várias substâncias, inclusive da amônia ${ }^{600}$. Além disso, este efeito é potencializado pela redução que a descompressão portal determina no gradiente pressórico existente entre o lume intestinal e os capilares venosos.

Chegada direta na circulação sistêmica

Obviamente, o desvio do sangue portal eleva as concentrações sistêmicas das substâncias absorvidas no intestino. Este efeito adquire maior importância se considerarmos, como já referido, o aumento concomitante da absorção intestinal e do fluxo portal ${ }^{239}$. Sabe-se que o aminograma do sangue portal é diferente daquele verificado no sangue sistêmico. As células hepáticas participam intensamente do metabolismo destas substâncias que, recentemente, foram relacionadas com os sintomas neuropsíquicos da EPS ${ }^{15}$.

Clareamento hepático insuficiente

As taxas sanguíneas dos agentes "tóxicos" lançados diretamente na circulação sistêmica mantêm-se elevadas, uma vez que o fígadio não é capaz de clareá-los na sua reciclagem através da artéria hepática. A capacidade de depuração foi demonstrada, experimentalmente, administrando-se sobrecargas iguais de acetato de amônio em cães normais (Fig. 138) e em cães com FE (Fig. 140)315. Nestes últimos, a amoniemia atingiu valor duas vezes maior que nos controles. Em macacos Rhesus com FE, a ingestão de refeições hiperprotéicas ocasionou taxas de amônia quatro vezes mais altas do que as observadas em macacos normais $^{908}$. 
Podem-se levantar três hipóteses teóricas para explicar a redução do clareamento hepático nos animais com FE:

- a reserva funcional dos hepatócitos não é suficiente para metabolizar as concentrações aumentadas conseqüentes à $\mathrm{FE}$;

- a redução do fluxo hepático total impede uma oferta/minuto suficiente;

- a falta de fatores hepatotróficos diminui a capacidade funcional do fígado.

Resultados experimentais e observa'ções clínicas afastam a primeira hipótese. Em cães, compararam-se as concentrações do sangue colhido nas veias suprahepáticas e na circulação periférica. A reserva funcional foi suficiente para clarear ofertas de amônia até quatro vezes e meia maiores do que as normais ${ }^{209}$. Mais recentemente, Dempster e col. ${ }^{185}$ e Price e col. ${ }^{599}$, empregando metodologia mais elaborada, chegaram a conclusões idênticas. Estudaram a função das enzimas do ciclo da uréia, responsável pela metabolização da amônia. Observaram que a reserva do sistema enzimático era maior do que a necessária para clarear as taxas verificadas nos pacientes com EPS ou coma. Demonstraram ainda que o clareamento hepático depende da oferta até níveis quatro a cinco vezes mais altos que os normais.

A segunda hipótese atribui a depuração hepática insatisfatória à diminuição de aproximadamente $50 \%$ do fluxo hepático ${ }^{640}$. Assim, esta redução faz com que a oferta das substâncias "tóxicas" ao fígado não atinja a quantidade necessária para depuração eficaz. Parte da reserva funcional hepatocelular continua inaproveitada.

Várias observações experimentais sugerem ser essa a hipótese mais próxima da realidade. Dempster e col., em $1962^{185}$, aplicaram sobrecargas de acetato de amônio em cães normais e em cães com FE. Notaram que a extração hepática de amônia era proporcional à concentração arterial. A mesma dose admi- nistrada em cães com FE causou concentrações arteriais duas vezes maiores que nos controles. Concluíram que a menor capacidade em remover amônia deve-se à redução do fluxo hepático total, estimada em $50 \%$.

Price e col., em 1966599, confirmaram esses resultados realizando infusão endovenosa de citrato de amônio em cães normais e em três modelos. Estudaram animais com diferentes alterações do fluxo hepático total, medido pelo método da infusão constante de BSP. Constataram que o clareamento da amônia depende do fluxo hepático e que sua eficácia é proporcional à quantidade de amônia que chega aos hepatócitos. Admitindo que a concentração sanguínea permaneceu constante durante a experiência, concluíram que a oferta ao fígado variou com o fluxo hepático total. Explicam, desta forma, a relação inversa entre o fluxo hepático total e as taxas periféricas de amônia. Por outro lado, demonstraram que o ponto de saturação (nível de extração máxima acima do qual deixa de existir correlação entre oferta e clareamento) era igual nos animais com FE e nos controles. Sugeriram que a reserva funcional das células hepáticas, e mais precisamente o sistema do ciclo da uréia, não está alterado nos animais com FE. A menor capacidade de depuração decorre do desvio em si e não de alteração funcional concomitante ou decorrente. Estas informações explicam a evolução do paciente estudado por MacDermott e Adams ${ }^{493}$. A FE causou EPS já no pós-operatório imediato apesar de função hepática normal.

A última hipótese relaciona o mau desempenho funcional à falta de fatores hepatotróficos. Como exposto anteriormente, dispõe-se de informações diretas e indiretas suficientes para admitir esta relação. Dados recentes corroboram esta teoria. Hernandez e Coulson ${ }^{348}$ demonstraram que o metabolismo normal dos aminoácidos pelas células hepáticas de- 
pende do aporte de insulina. Nos animais com FE a oferta está nitidamente diminuída ${ }^{838}$, permitindo supor que a alteração do aminograma decorra, em parte, de redução funcional. Muitos conferem aos aminoácidos importante papel na etiologia da EPS 202-240-250. Pode-se concluir então que, além da redução na oferta de substâncias a serem clareadas pelo fígado, a FE determina outras alterações responsáveis pelo quadro neurológico.

\section{3 \\ FISIOPATOLOGIA DAS ALTERACOOEES NEUROLÓGICAS}

A EPS representa uma entidade de caráter bioquímico neurofisiológico e não uma alteração estrutural do sistema nervoso central. Clinicamente, vários estudos 170-234 foram efetuados em pacientes com EPS, mostrando diminuição no fluxo sanguíneo cerebral, no consumo cerebral de oxigênio e, ainda que menos claramente, no consumo cerebral de glicose.

Alguns autores acreditam que o defeito bioquímico básico é representado por redução do metabolismo energético cerebral. Esta explicação é fácil de ser aceita pelos seus aspectos lógicos. Não elucida, porém, alguns dos pontos básicos, sendo por isso considerada como demasiado simplista ${ }^{698}$. Não foi possível estabelecer, definitivamente, se a queda do consumo cerebral de oxigênio é causa ou efeito da perda do estado de consciência. Por outro lado, sabe-se que o cérebro é constituído por várias áreas com função especializada. Acredita-se que o estado de alerta depende da função adequada do sistema reticular ascendente do tronco cerebral. O córtex exerce influência no tipo de pensamento que caracteriza o estado de consciência. Assim, análises globais do metabolismo cerebral não podem fornecer esclarecimentos precisos sobre o problema.
Experimentalmente, muitos estudos têm sido realizados para investigar o mecanismo patogenético da EPS e do coma hepático. A maioria focaliza a toxicidade da amônia, tendo fornecido resultados bastante sugestivos de sua ação central. Reduz o metabolismo energético do cérebro 840 , acumula ácido gamaaminobutírico (inibidor de vários neurotransmissores) 291 e diminui a reserva de neurotransmissores como a acetilcolina ${ }^{86}$.

Dentre as teorias aventadas para explicar esses efeitos, destaca-se aquela que relaciona nas células cerebrais o excesso de amônia com a diminuição dos fosfatos ricos em energia. Tal conceito se justifica, visto que:

- a transformação cerebral de amônia em glutamina utiliza energia na forma de adenosina-3-fosfato (ATP);

- a amônia interfere no ciclo do ácido cítrico, que representa a maior fonte de fosfatos ricos em energia;

- a diminuição de fosfatos ricos em energia pode causar distúrbios na fisiologia cerebral através de alteração na repolarização neuronal;

- esta hipótese é consistente com a queda no consumo cerebral de oxigênio, observada em pacientes em coma hepático.

As maiores críticas a esta interpretação têm base nas limitações da metodologia empregada. Os fosfatos ricos em energia são extremamente lábeis. Por outro lado, a anestesia altera o metabolismo energético cerebral sendo praticamente impossível colher amostras de tecido cerebral sem modificações grosseiras. Esta causa de erro é maior em áreas situadas profundamente no cérebro, como no tronco cerebral, onde o resfriamento rápido das amostras é mais difícil do que em áreas superficiais.

Mesmo aceitando estas limitações, é interessante notar que estudos em ratos e camundongos, intoxicados pela amônia, demonstraram diminuição nas concen- 
trações de ATP e fosfocreatina (fonte energética de reserva) no tronco cerebral. No córtex, as concentrações estavam preservadas ${ }^{699}$. Esta provável localização dos efeitos da intoxicação ganha particular interesse. Aceita-se que a alteração funcional desta área possa determinar alguns dos sintomas verificados na EPS e no coma hepático, como hiperpnéia, asterixis e rigidez descerebrada ${ }^{13}$.

Algumas observações paralelas são interpretadas ${ }^{698}$ como evidência da teoria da redução dos fosfatos ricos em energia. Dentre elas, salienta-se a interferência exercida por vários fatores na ação tóxica da amônia. Dessa maneira, a hipertermia e a hipóxia potencializam a ação tóxica. A hipotermia, pelo contrário, exerce efeito protetor. Cita-se a relação entre produção e consumo de energia pelo cérebro como elo mediador de tais efeitos. A hipertermia estimula o consumo cerebral de energia $^{700}$. A hipóxia diminui a produção cerebral de fosfato ${ }^{847}$. A hipotermia reduz o consumo energético ${ }^{700}$.

POR QUE A EPS NÃO OCORRE EM TODOS OS ANIMAIS OU PACIENTES SUBMETIDOS A UMA FE

Há muito, sabe-se que nem todos os animais com $\mathrm{FE}^{41-482}$ e nem todos os pacientes com APC 69 apresentam EPS. Tornou-se claro também que os animais com FE não mostram a mesma sensibilidade à ingestão protéica. Já Rothberger e Winterberg, em $1905^{665}$, observaram que de dezoito animais operados apenas sete apresentaram sinais neurológicos. Não encontraram justificativa para diferença no diâmetro da fístula nem na presença de circulação colateral. Pouco mais tarde, este fato foi corroborado por Matthews e Miller ${ }^{485}$. Em 35 cães com FE, verificaram, em apenas três, efeitos da ingestão de carne. Para explicar este comportamento, Silberstein, em 1924 ${ }^{732}$, considerou as lesões neurológicas da FE como decorrentes de uma encefalite semelhante à afecção humana epidêmica. Provavelmente estava influenciado pela epidemia que ocorreu após a Primeira Guerra Mundial. Segundo o autor, apenas os cães com $\mathrm{FE}$ infectados com o vírus da encefalite apresentavam o quadro neurológico. Esta hipótese foi negada por grande número de trabalhos experimentais iniciados por György e Kleinschmidt, em 1927324. Mostraram falta de aspectos inflamatórios histológicos no cérebro de cães necropsiados após quadro neurológico típico.

Afastada esta explicação, realizaram-se três tipos diferentes de pesquisa. Pretendia-se:

- identificar maior suscetibilidade cerebral aos agentes "tóxicos" em pacientes com insuficiência hepática;

- estudar os efeitos protetores da circulação colateral hepatopetal nos pacientes com APC;

- investigar se a APC provoca efeitos neuropsíquicos em pacientes com redução prévia do fluxo portal hepatopetal.

\section{$4 \mathrm{~A}$ \\ Suscetibilidade cerebral}

$\mathrm{O}$ conceito de que pacientes com moléstias hepáticas apresentam sensibilidade cerebral aumentada, isto é, suscetibilidade aos agentes "tóxicos", teve origem nas seguintes observações:

- a EPS pode ser desencadeada, em hepatopatas, por uma série de fatores como infecção, sedativos, desequilíbrio eletrolítico e hipóxia, que são bem tolerados por pacientes com fígado normal;

- estudos com perfusão de cérebro de gato sugeriram que a retirada do fígado do circuito determina redução das atividades metabólicas e elétricas cerebrais. As experiências demonstraram que a adição de substâncias normalmente sintetizadas pelo fígado ao perfusato (uridina e citidina) compensava os efeitos da 


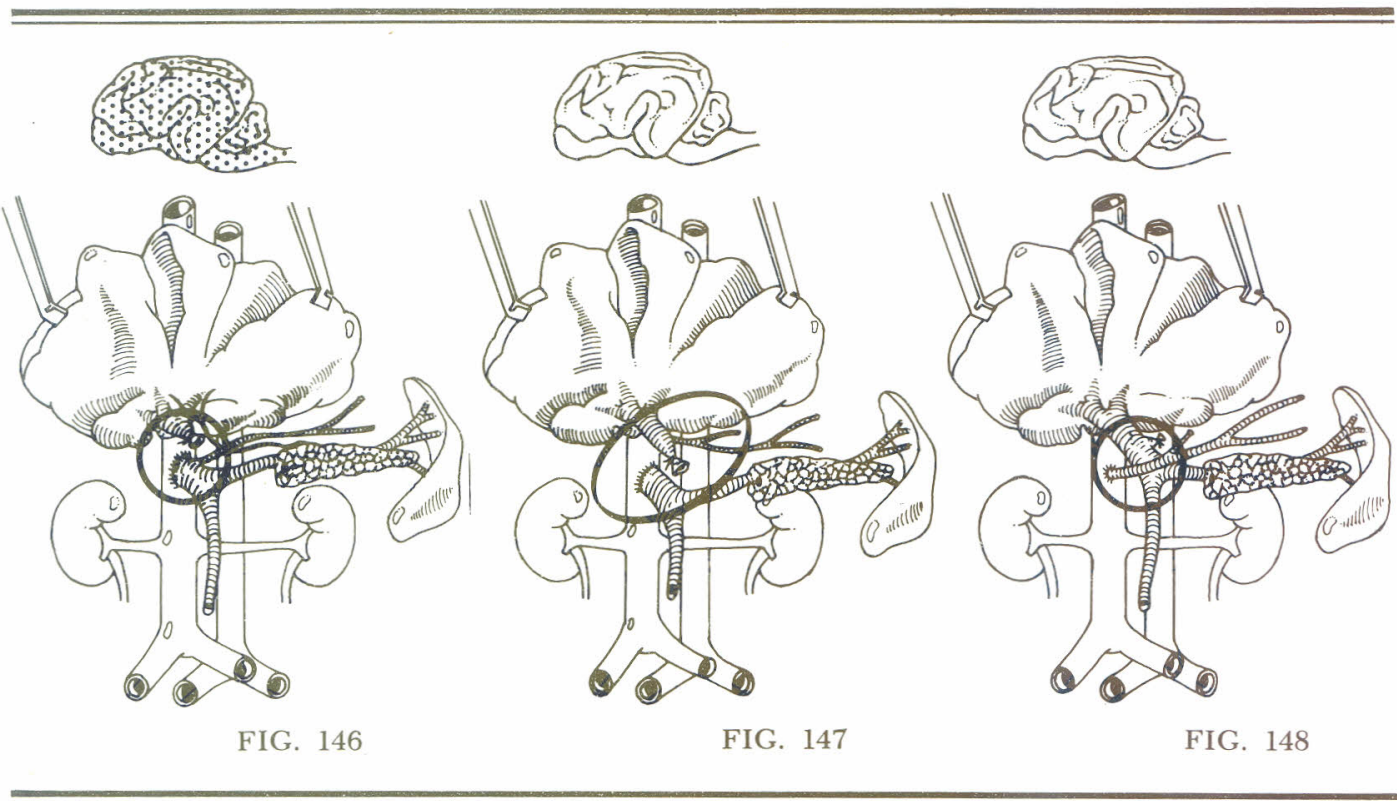

retirada do órgão, restaurando a atividade cerebral normal ${ }^{282}$;

- demonstrou-se, "in vitro", que a amônia deprime mais intensamente a respiração de fatias de cérebro de ratos com insuficiência hepática do que de outras retiradas de animais com fígado normal ${ }^{842}$.

Clinicamente, aceita-se que a suscetibilidade cerebral pode resultar de efeito cumulativo de "toxinas" agindo por longos períodos em concentrações subpatogênicas. Esta hipótese elucidaria o aparecimento de coma em EHE submetidos a hiperamoniemia prolongada. As mesmas taxas de amônia mostraram-se inócuas quando mantidas por períodos mais curtos ${ }^{845}$.

\section{$4 B$}

Efeitos protetores da circulação colateral hepatopetal

Desde as verificações iniciais do grupo de Pavlov, em 1893326, sabe-se que podem ser evitados os efeitos neurológicos da FE (Fig. 146) pela preservação de pequena parte do fluxo portal hepatopetal. Empregou-se a ligadura da veia porta abaixo da veia gastroduodenal (Fig. 147). A falta de EPS em cães com anastomose desta veia na cava inferior (Fig. 148) foi interpretada como prova de que os efeitos protetores eram conseqüentes à preservação parcial do fluxo. Mais tarde, em 1936, Bollman e Mann ${ }^{78}$ conseguiram a mesma proteção realizando, préviamente, oclusão da veia cava acima do local da futura anastomose. Criaram, assim, colaterais hepatopetais. Bollman e col., em experiências mais recentes ${ }^{77}$, confirmaram aquele fenômeno de maneira mais clara e elegante. Inicialmente, realizaram uma FE habitual e obtiveram o quadro neurológico esperado (Fig. 149). Após vários episódios de coma, reoperaram os animais. Reduziram o calibre da veia cava acima da anastomose para $25 \%$ de seu diâmetro. Todos os animais que sobreviveram à segunda operação readquiriram peso normal e não mais apresentaram sinais neurológicos (Fig. 150). $\mathrm{O}$ efeito benéfico foi atribuído à circulação colateral hepatopetal desenvolvida 

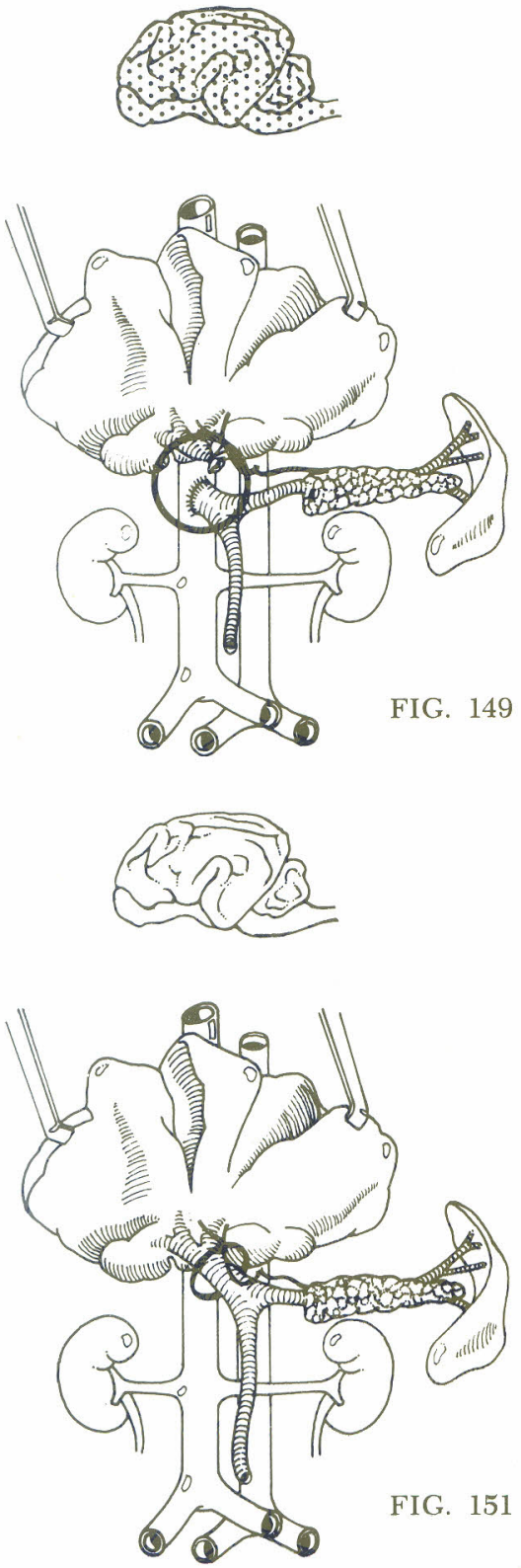
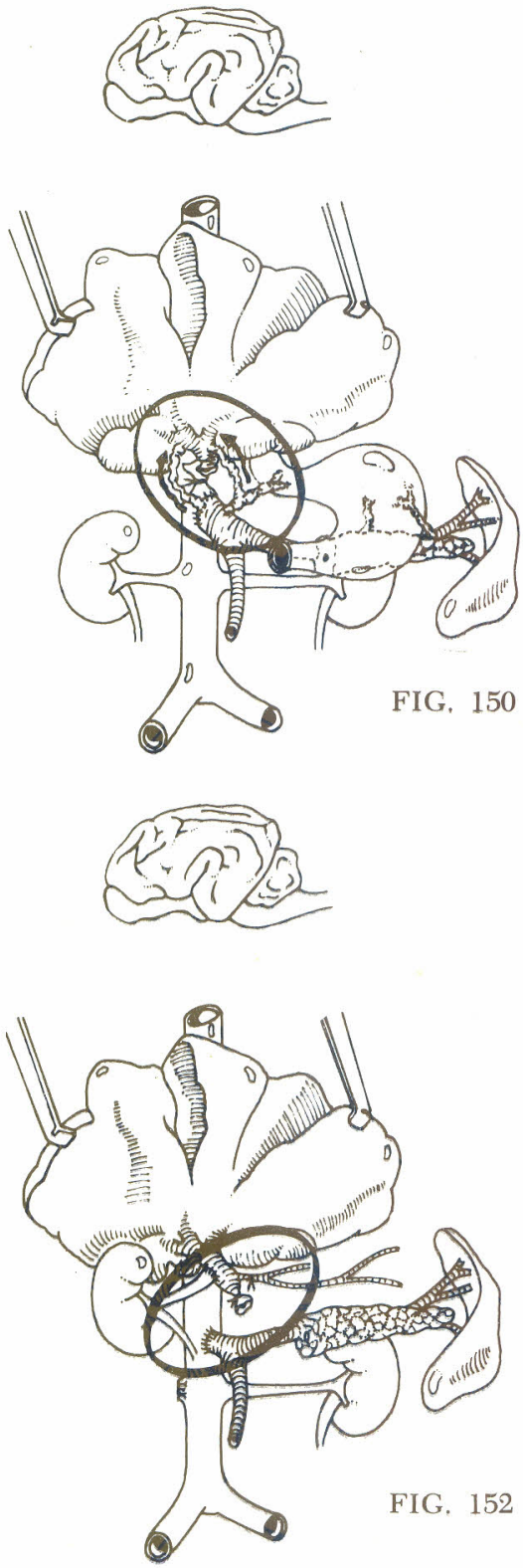

após a reoperação. Em 1965, Jolly e col. ${ }^{390}$ desenvolveram um modelo denominado "desvio portal parcial". Realizaram uma anastomose mesentérico-cava, desviando para a circulação sistêmica apenas o sangue proveniente do intestino. Preservaram o fluxo hepatopetal pancreático-esplênico (Fig. 58). Nestes animais, o teste de tolerância à amônia forneceu resultados semelhantes aos dos controles. Os animais com FE mostraram comportamento diferente. Concluíram que a persistência do fluxo pancreáticoesplênico foi capaz de evitar a elevação 

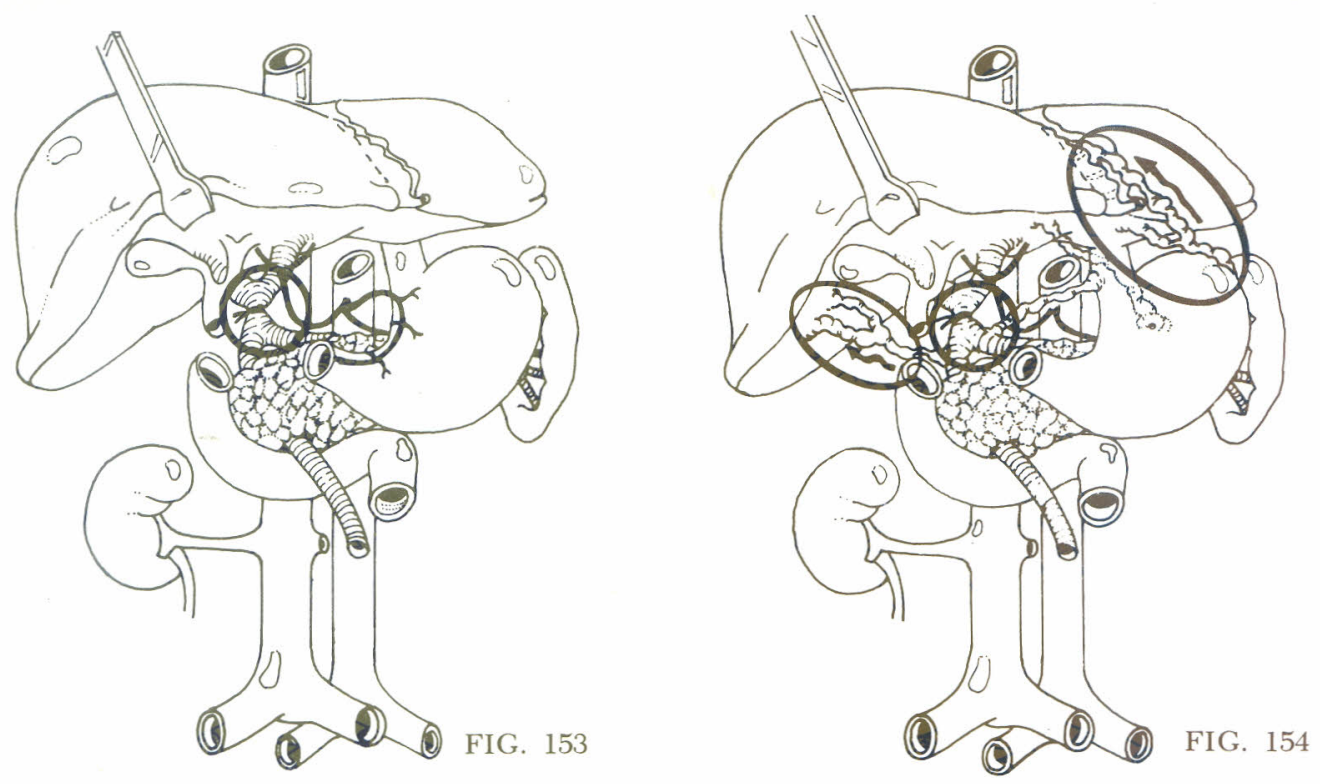

da taxa de amônia pela menor diminuição do fluxo hepático total.

Em 1966, Kline e col. ${ }^{413}$ compararam três grupos de animais. Estudaram cães normais (Fig. 151), cães portadores de FE (Fig. 149) e cães com desvio incompleto e preservação parcial do fluxo portal para o fígado (Figs. 147-152). Demonstraram, nos últimos, evolução normal sem quadro neurológico e sem aumento de astrócitos. Os animais com $\mathrm{FE}$ completa apresentaram a evolução prevista.

Estes dados experimentais, analisados atualmente e de posse dos conhecimentos adquiridos nos últimos dez anos, permitem outra interpretação. É lícito supor que o benefício observado nos modelos com parte do fluxo hepatopetal preservado decorra do fornecimento de fatores hepatotróficos. Aceitando-se esta interpretação, torna-se fácil compreender a falta de efeitos no parênquima hepático. A ausência de EPS, entretanto, abre novas perspectivas. Define-se uma relação entre aporte de fatores para as células hepáticas e efeitos neuropsíquicos.
Considerando informações previamente apresentadas, surge estímulo para reunir vários aspectos do problema. A insulina

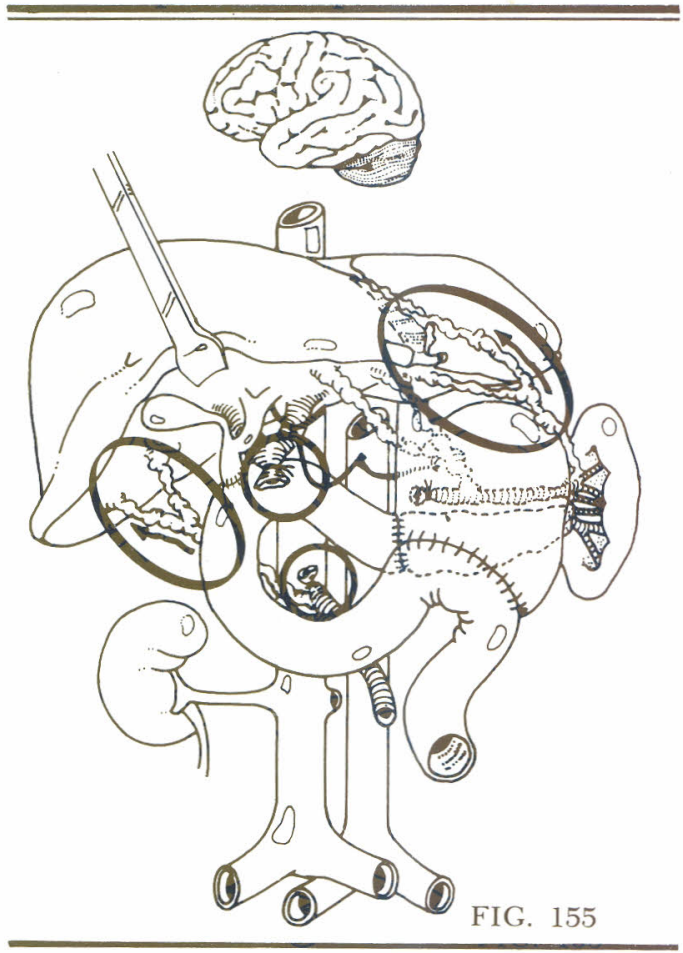



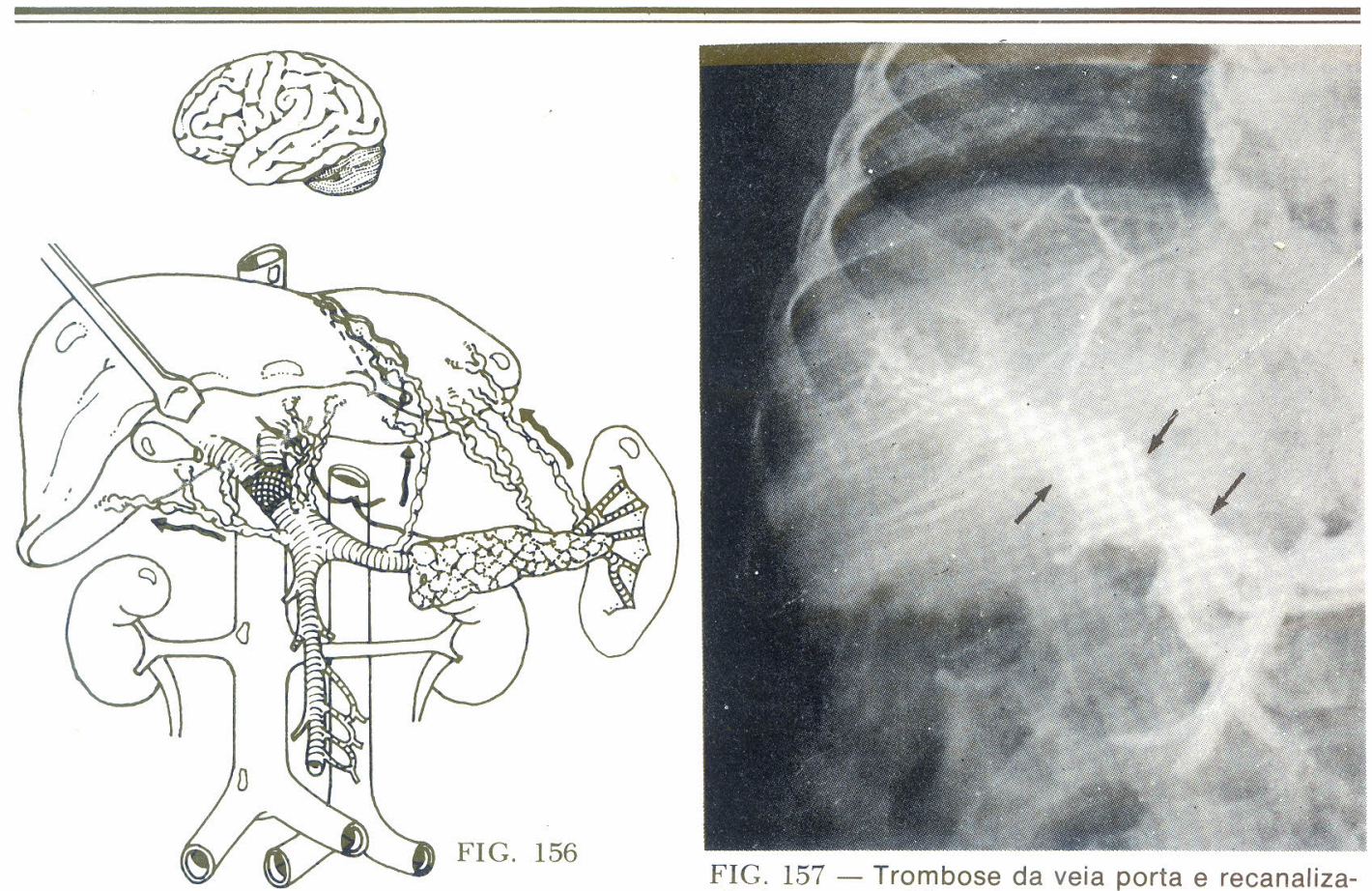

FIG. 157 - Trombose da veia porta e recanalização hepatopetal (setas).

age no metabolismo hepático dos aminoácidos ${ }^{348}$. Os aminoácidos exercem ação neuropsíquica ${ }^{249}$. A manutenção de fornécimento parcial de sangue portal ao fígado evita a EPS ${ }^{390-413}$. Pequena quantidade de insulina e outros hormônios do sangue portal seriam capazes de impedir alterações no aminograma e evitar a EPS?

Esta linha de idéias é reforçada por outra série de observações clínicas e experimentais. McDermott e col., em $1954^{493}$, e Hubbard, em $1958^{358}$, realizaram uma $\mathrm{APC}$ em pacientes com fígado normal e tumor pancreático. Observaram graves alterações hepáticas e EPS recorrente (Fig. 142). Pelo contrário, Child III e col.129-131 apresentaram uma variante técnica para tratar o carcinoma de cabeça de pâncreas. Num primeiro tempo, ligaram a veia porta (Fig. 153) para estimular o desenvolvimento de circulação colateral (Fig. 154). Em segundo tempo efetuaram a AMC. Observaram falta de compli- cações neuropsíquicas (Fig. 155). Comportamento semelhante fora notado na Macaca mulata, na qual a oclusão deliberada da veia porta foi seguida, após quatro meses, de neoformação vascular hepatopetal no hilo hepático. Esta restabeleceu o trânsito normal através dos sinusóides ${ }^{132}$. Também não observaram complicações neurológicas ou de qualquer outro tipo.

Compreende-se, desse modo, a evolução aparentemente paradoxal apresentada pelos pacientes com trombose da veia porta desde a infância. Apesar da ausência de fluxo portal direto, faltam sintomatologia neurológica e diminuição de reserva funcional hepática. Em análise mais superficial, esse comportamento foi interpretado pelos pioneiros da aplicação clínica da APC como uma demonstração da inocuidade do desvio do sangue portal. No entanto, esses pacientes não podem ser comparados com os portadores de APC. A transformação 
cavernomatosa da veia trombosada e a circulação hepatopétal permitem que parte do sangue portal continue em direção aos hepatócitos, protegendo as células hepáticas dos efeitos do desvio total (Figs. 156-157).

$$
\begin{array}{r}
4 \mathrm{C} \\
\text { Adaptação hepatocelular } \\
\text { pela redução } \\
\text { lenta e progressiva } \\
\text { do fluxo portal } \\
\text { hepatopetal }
\end{array}
$$

Em 1963, Warren e col. ${ }^{851}$ relacionaram a incidência da EPS com o fluxo portal hepatopetal pré-operatório. Observaram, retrospectivamente, maior incidência da complicação em cirróticos com fluxo portal preservado ou ligeiramente diminuído antes da cirurgia. Pelo contrário, não verificaram efeitos neurológicos naqueles nos quais antes da operação tinham demonstrado, radiologicamente, fluxo portal pequeno ou mesmo ausente. Concluíram que a interrupção súbita do fluxo venoso portal causava agressão maior do que a interrupção lenta e progressiva. Não encontramos, porém, dados para explicar o mecanismo de adaptação sugerido por esses autores.

Da grande quantidade de informações disponíveis sobre os efeitos neurológicos da FE, percebe-se que muitos aspectos da questão permanecem em aberto. Todavia, tornam-se mais claros os seguintes pontos do problema:

- os efeitos neurológicos podem decorrer apenas do desvio em si sem insuficiência hepática concomitante;

- a amônia é citada como o agente "neurotóxico" mais importante, ainda que outras substâncias devam exercer ação semelhante;

- a redução no fluxo hepático total diminui a eficácia do clareamento dos agentes "neurotóxicos" na sua passagem pelo fígado através da artéria hepática;

- nos últimos anos têm merecido muita atenção as alterações dos aminoácidos no sangue periférico, que agiriam provavelmente por meio de efeitos nos neurotransmissores centrais;

- a persistência de pequena parte do fluxo portal hepatopetal impede o aparecimento dos efeitos neurológicos.

EFEITOS CARDIOCIRCULATÓRIOS

$$
\text { OBSERVAÇÕES EM NORMAIS }
$$

Experimentalmente, em cães sem lesão hepática, o desvio do sangue portal determina aumento do débito cardíaco. Estimou-se a elevação como sendo da ordem de $53 \mathrm{ml} / \mathrm{kg} / \mathrm{min}$, equivalente a $35 \%$ do valor observado no pré-operatório ${ }^{388}$. Faltam referências sobre os efeitos cardiocirculatórios da FE em pacientes com fígado normal.

\section{OBSERVAÇÕES EM CIRRÓTICOS}

Várias investigações clínicas desse tipo foram efetuadas em pacientes com cirrose hepática. Contudo, como estes pacientes já manifestam, antes da cirurgia, alterações cardiocirculatórias importantes, torna-se oportuno mencioná-las antes de analisar os efeitos da FE. De há muito $229-416$, sabe-se que os cirróticos podem apresentar uma síndrome cardiovascular, caracterizada por aumento do débito cardíaco e do volume sistólico médio, de um lado, e diminuição da resistência vascular periférica, de outro. Esta explica a falta de elevação e mesmo a queda da pressão arterial simultâneas ao aumento do débito cardíaco. É atribuída à abertura generalizada de fístulas arteriovenosas periféricas e esplâncnicas pré-capilares ${ }^{578}$ (Fig. 158) que agem no conjunto como uma fístula arteriovenosa única ${ }^{46-526}$. Aceita-se que a abertura é conseqüente à ação de uma subs- 
tância vasodilatadora originada no intestino e metabolizada no fígado ${ }^{526}$. Suas taxas estão aumentadas nos cirróticos, quer pela insuficiência hepática, quer pelo desvio direto para a circulação sistêmica através da circulação colateral. Mais recentemente $^{247}$, esse efeito foi relacionado com o metabolismo alterado de alguns aminoácidos, como a fenilalanina, o triptofano e a tirosina. Admite-se que a elevação das taxas desses componentes normais é capaz de alterar as cadeias enzimáticas responsáveis pela síntese de várias substâncias vaso-ativas, como catecolaminas. Esta hipótese é corroborada pela observação de que o aumento do débito cardíaco é maior nos casos com hipertensão portal e circulação colateral hepatofugal (bloqueio intra-hepático). O aumento do débito cardíaco é menos intenso nos casos com circulação colateral hepatopetal(bloqueio extra-hepático) 229-526

A realização de:uma $A P C$, ou de outra modalidade de tratamento cirúrgico que desvie o sangue portal para a circulação sistêmica, provoca um efeito hemodinâmico paradoxal. Após operações dè grande porte, nota-se, geralmente, redução do débito cardíaco mas em portadores de cirrose e hipertensão portal, a APC pode determinar um estado hiperdinâmico (Fig. 159). É semelhante àquele observado no choque toxêmico com diminuição da extração periférica de oxigênio e depressão miocárdica dé intensidade variável ${ }^{726}$. Percebe-se, desta forma, que, em cirróticos, a APC causa exacerbação da síndrome pré-operatória ${ }^{229}$. Refere-se, após o desvio portal, aumento adicional do débito cardíaco de $17 \%$ em média. Esse efeito é conseqüente a vários fatores que agem na mesma direção fisiopatológica. O desvio do sangue portal em si reduz a eficácia dos hepatócitos em metabolizar as substâncias váso-ativas. Paralelamente, constata-se aumento do fluxo
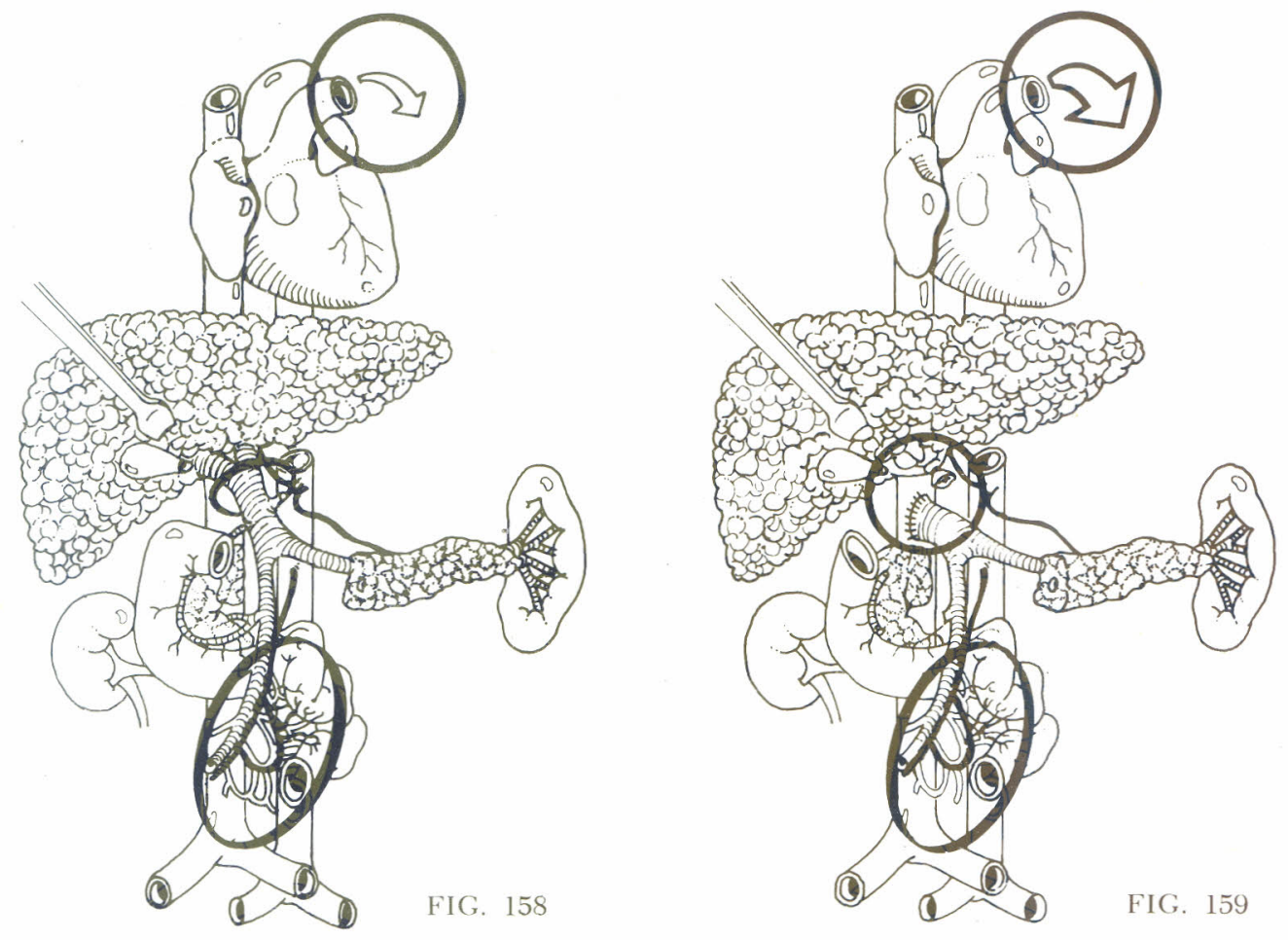
portal ao redor de $100 \%{ }^{464}$, decorrente de duas alterações hemodinâmicas. A primeira é representada por redução na resistência oferecida ao sangue portal. A barreira sinusoidal hepática é substituída pela baixa pressão da veia cava. A segunda é representada pelo aumento do fluxo arterial esplâncnico. Este aumento foi demonstrado, em cães, por Delaney e col. ${ }^{180}$. Injetaram, endovenosamente, $\mathrm{K}^{42}$ e $\mathrm{Rb}^{86}$. Em animais com FE, mediram maior radioatividade em fragmentos de estômago, pâncreas e duodeno, do que em animais controle. Em cirróticos, o grande número de fístulas arteriovenosas presentes no sistema portal potencializa esses efeitos ${ }^{388}$ e explica a magnitude do aumento do fluxo portal, maior do referido, experimentalmente, em cães com fígado normal. Nos cirróticos não operados, o estado hiperdinâmico do território portalnão se manifesta em toda sua exuberância em conseqüência do bloqueio pós-sinusoidal ${ }^{464}$. A APC desvia o sangue portal para a veia cava e permite maior escoamento das fístulas arteriovenosas esplâncnicas. Este, por sua vez, aumenta o retorno venoso, causa maior volume ventricular diastólico e, segundo a lei de Starling, determina maior volume sistólico e conseqüente acréscimo no débito cardíaco ${ }^{388}$. Alguns autores admitem mecanismos etiológicos mais complexos. A redução da resistência vascular periférica acarreta uma tendência para pressões arteriais mais baixas. Excitariam os baroreceptores estimulando aumento adicional do débito cardíaco.

Estas informações despertaram interesse em vários autores, para relacionar a gravidade das alterações hemodinâmicas pré-operatórias com a evolução de cirróticos submetidos a uma $\mathrm{APC}^{\mathbf{1 8 3}}$. Retrospectivamente, observaram associação significativa entre os portadores de estado hiperdinâmico mais acentuado e a mortalidade operatória. Mais tarde, o mesmo grupo ${ }^{312}$ estudou 47 pacientes operados. Estabeleceu que a reserva ventricular é importante para o prognóstico pós-operatório imediatopermitindo prever a capacidade de suportar a piora hemodinâmica causada pela derivação portal. Outros autores ${ }^{727}$ propuseram um critério para melhor indicar a cirurgia em cirróticos. Desenvolveram um índice pré-operatório, de acordo com a importância dos parâmetros cardiocirculatórios. Empregaram computadores programados para avaliar, conjuntamente, as condições cardiocirculatórias dos candidatos a derivações porto-cava. Valorizaram, principalmente, a resistência periférica e a capacidade de contração do miocárdio. Conseguiram separar os pacientes com indicação cirúrgica em três grupos, com probabilidade de sobrevida maior que $90 \%$, maior que $50 \%$ e menor que 20\%. O índice cardiocirculatório assim calculado mostrou-se capaz de prever, corretamente, a diferente evolução pós-operatória em pacientes com quadros clínico e laboratorial semelhantes. Caracterizaram assim que a reserva circulatória influi também decisivamente no prognóstico e no risco cirúrgico desses pacientes.

\section{3 \\ OBSERVAÇÔES EM ESQUISTOSSOMÓTICOS HEPATESPLENICOS}

Não existem referências precisas quanto aos efeitos da APC $\cdot$ ou de outros tipos de desvio porto-sistêmico em EHE. Entretanto, são conhecidas as alterações hemodinâmicas causadas pela parasitose (Fig. 160). A alteração hemodinâmica mais freqüente é representada por um regime de hipertensão pulmonar com pressão sistólica variando entre 42 e 132 $\mathrm{mm} \cdot \mathrm{Hg}^{118}$, ou 17,3 e $62,7 \mathrm{~mm} . \mathrm{Hg}^{318}$. Refere-se também elevação proporcional no índice de resistência arterial pulmonar que atinge, em média, $925 \mathrm{dyn} /$ $\mathrm{seg} / \mathrm{cm}^{-5},{ }^{118}$. Experimentalmente, verifica-se redução no débitocardíaco e apre- 
sentaram-se várias teorias para explicar a etiologia da hipertensão pulmonar. Citaram-se obstrução mecânica das arteríolas pulmonares por ovos e vermes que chegam pela circulação colateral ${ }^{715}$; endarterite crônica de tipo alérgico ${ }^{380-232}$; fator vaso-ativo agindo especificamente no território pulmonar e endarterite aguda, associada a uma reação alérgica intensa ${ }^{463}$. Aceita-se que vários mecanismos possam coexistir, agindo com intensidade variável, no desencadeamento do quadro anatomofuncional. Paralelamente, descreveu-se síndrome cianótica mais rara $^{233}$, atribuída por alguns à presença de microfístulas arteriovenosas pulmonares que funcionariam também como válvula de escape para a pressão pulmonar ${ }^{233}$.Explicam os níveis pressóricos, não exageradamente elevados, referidòs em muitos $\operatorname{casos}^{681}$. Guimarães e col., em 1976 ${ }^{318}$, apresentaram prova adicional da existência de fístulas arteriovenosas pulmonares. Observaram correla- ção inversa entre a concentração arterial de $\mathrm{CO}_{2}$.e o índice de resistência arterial pulmonar em 96 dos 134 EHE estudados.

Alguns autores denominam de obstrução porto-pulmonar esquistossomótica a síndrome representada por hipertensão pulmonar, hipertrofia ventricular direita e insuficiência cardíaca. Estas alterações foram encontradas entre nós por Lopes de Faria $^{447}$, em doze de 89 casos de necropsia. Rodríguez e col. ${ }^{654}$, em Porto Rico, relatam alterações semelhantes em dez dos 28 casos também de necropsia, seis dos quais falecidos por insuficiência cardíaca. Estes últimos autores mencionam, adicionalmente, sete casos com cor pulmonale. Destes, três apresentaram insuficiência cardíaca,e um, sintomatologia menos evidente. Três eram assintomáticos.

Os EHE não apresentąm problemas hemodinâmicos semelhantes aos descritos em cirróticos, a não ser as alterações
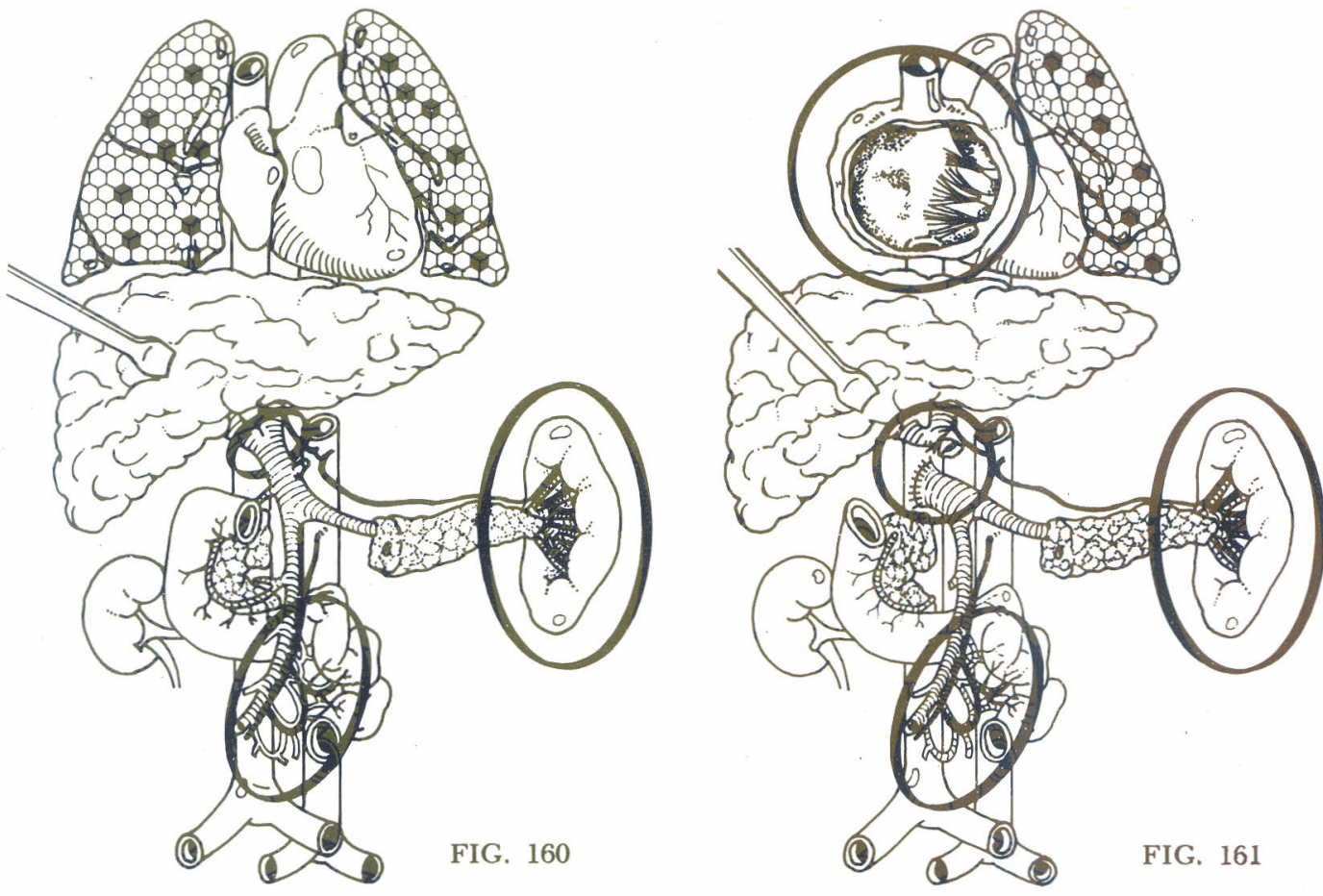
hemodinâmicas decorrentes das lesões pulmonares. Autores egípcios ${ }^{256}$ citam que, de dezoito pacientes estudados, apenas um manifestou estado hïperdinâmico relacionando-o com a circulação colateral muito desenvolvida. Os dezessete restantes apresentaram índice cardíaco e resistência vascular periférica dentro dos limites normais.

Os mesmos autores forneceram alguns dados relacionados com os efeitos do desvio do sangue portal para a circulação sistêmica através de uma APC $^{256}$ (Fig. 161). A análise de dezoito EHE sem cor pulmonale no pré-operatório demonstrou que dezessete desenvolveram um ou mais sinais do estado hiperdinâmico após a cirurgia. A única exceção correspondeu a um paciente que fora submetido a esplenectomia dois anos antes. Compararam ogrupooperado com um grupo controle. Encontraram diferença estatisticamente significativa no índice cardíaco e na resistência vascular periférica. Nestes casos, a derivação portal provocou também aumento do fluxo pulmonar mas sem insuficiência cardíaca.Atribuiram a preservação funcional do coração à falta de lesões pulmonares associadas. Em pacientes com afecção pulmonar concomitante podem ocorrer sérias conseqüências. Rodríguez e col.654 citam três pacientes submetidos a APC que apresentaram grave insuficiência cardíaca no pós-operatórioe queem um caso determinou a morte do paciente. Entre nós, Lopes* atribui o quadro de insuficiência cardíaca intratável e o óbito ocorridos no período pós-operatório imediato de seis EHE à hipertensão pulmonar preexistente (Fig. 161). Chamou a atenção para o fato de que todos os pacientes mostravam reação de Machado e Guerreiro negativa, traçado eletrocardiográfico dentro dos limites da normalidade e área cardíaca normal. Baseou o diagnóstico de hipertensão pulmonar apenas na ausculta cardíaca e no traçado do vetocardiograma. Num dos casos a necropsia

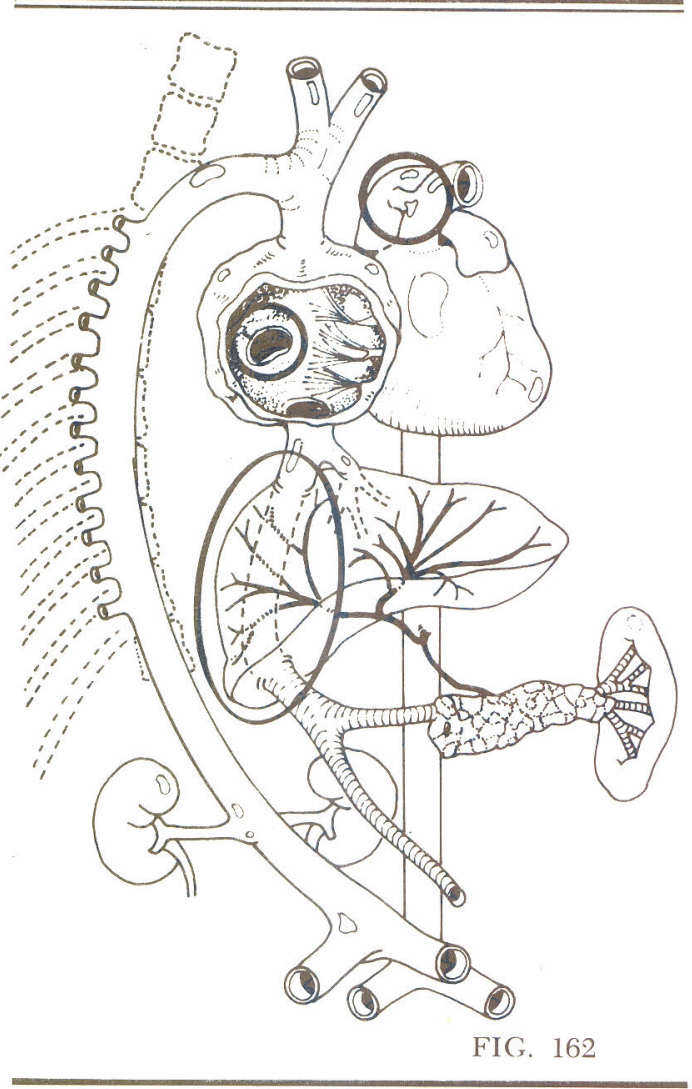

evidenciou dilatação global e hipertrofia do coração direito, granulomas miliares esquistossomóticos em ambos os pulmões e alterações arteriais conseqüentes à hipertensão pulmonar.

Para interpretar estas alterações, parece-nos oportuno comentar os dados referidos por Hellweg ${ }^{345}$. Relata a evolução clínica e os achados de necropsia numa menina de cinco meses e meio. Era portadora de ausência congênita da porção proximal e dos ramos intra-hepáticos da veia porta associada a ducto arterioso e hipertensão pulmonar. Nessa anomalia, o retorno do sangue portal diretamente para o coração, sem passar pelos sinusóides hepáticos, mimetiza as condições hemodinâmicas de uma APC. A hipertensão pulmonar conseqüente ao ducto arterioso pode ser comparada com o quadro hemodinâmico pulmonar da es- 
quistossomose mansônica. Aceitando-se esse paralelismo, podem ser comentadas as observações feitas pela autora, que permitiram o diagnóstico de. insuficiência cardíaca e cor pulmonale na necropsia (Fig. 162). Com efeito, o coração apresentou-se globalmente dilatado e hipertrofiado, pesando $100 \mathrm{~g}$ numa criança cujo peso normal calculado para este órgão é $29 \mathrm{~g}$. Nos pulmões, constatou aumento do número das arteríolas com espessamento da camada média e proliferação da íntima. Já foram expostos dados que permitem atribuir a insuficiência cardíaca ao aumento do débito conseqüente à falta da resistência sinusoidal associado à hipertensão pulmonar. Apenas ducto arterioso ou apenas anomalia portal, como verificado em outros três casos citados por Hellweg ${ }^{345}$, não causam insuficiência cardíaca desse tipo. Podese admitir que as alterações hemodinâmicas do caso em questão tenham sido causadas pela simultaneidade das duas lesões que mimetizam de um lado o desvio do sangue portal e, do outro, a hipertensão pulmonar dos EHE.

EFEITOS NA SECREÇÃO GÁSTRICA

\section{OBSERVAC ÕES EXPERIMENTAIS EM MODELOS COM FÍGADO NORMAL}

Estudos realizados nas últimas quatro décadas comprovaram que, em animais com fígado normal, a FE determina hipersecreção gástrica durante o período de digestão. A primeira demonstração desse efeito parece ter sido mencionada em 1933 por Lebedinskaja ${ }^{425}$. Notou, nas bolsas gástricas com inervação vagal de dois cães, (Fig. 163) que a FE provocou aumento na duração, volume e acidez da secreção (Fig. 164).

Gerez e Weiss ${ }^{283}$ confirmaram esses resultados. Analisaram os efeitos de refeições hiperprotéicas na secreção de bolsas de Pavlov antes e depois de reali-
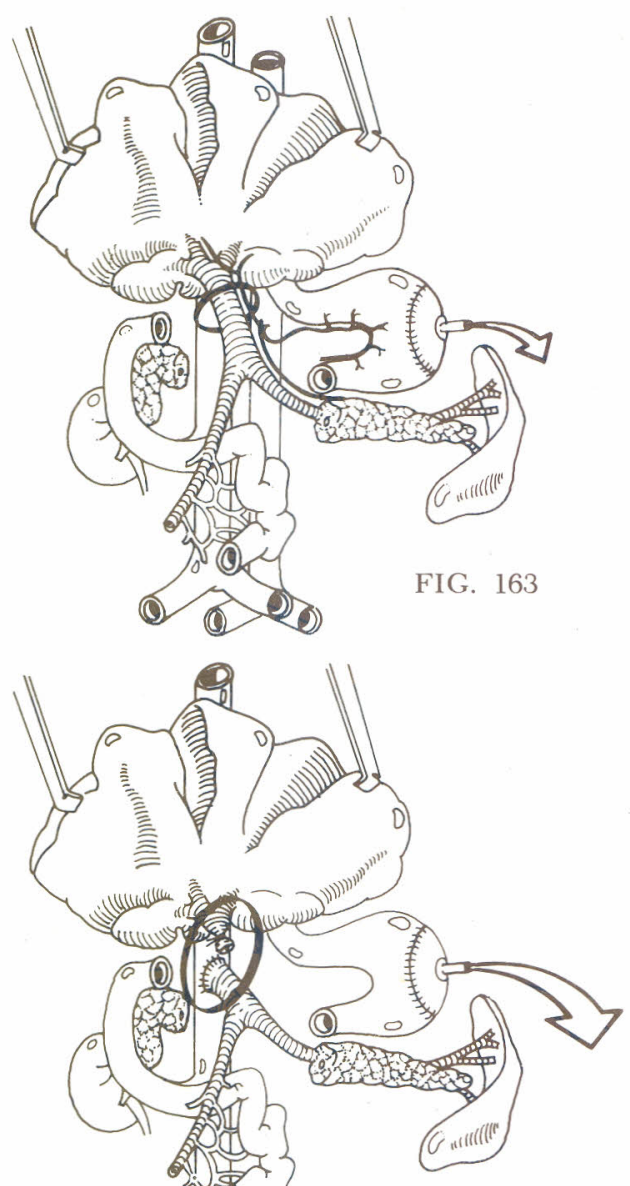

FIG. 164

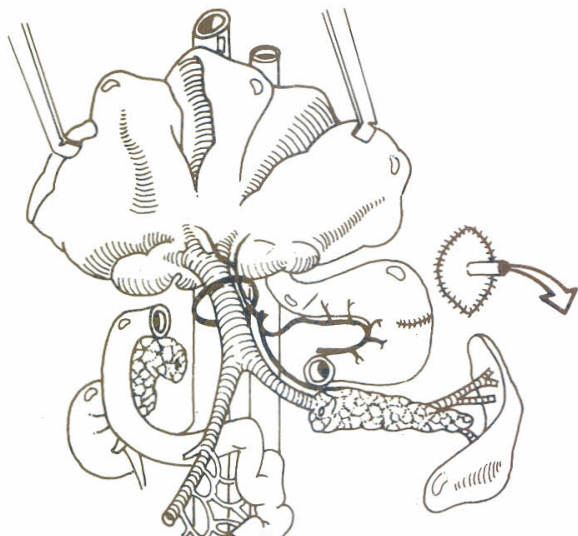

FIG. 165 
zar uma FE. Interpretaram os resultados como demonstrativos da existência de substâncias atuantes na secreção gástrica. Em condições normais, esses fatores eram retidos ou destruídos, em todo ou em parte, pelo fígado. Não puderam precisar o local da origem dos agentes secretagogos, uma vez que a hipersecreção ocorreu logo depois da ingestão dos alimentos e durou de cinco a seis horas.

Mais tarde, Clarke e col. ${ }^{136}$ identificaram a origem desses fatores por meio de uma série de experiências em cães com bolsas de Heidenhain (Fig. 165). Efetuaram inicialmente uma AMC (Fig.166). Verificaram aumento médio de $269 \%$ na secreção da bolsa gástrica àpós a administração de uma refeição de prova. Numa fase seguinte, realizaram uma transposição porto-cava total (Fig. 167), dirigindo o sangue mesentérico novamente em direção ao fígado. Assim, determinaram o retorno da secreção ácida aos níveis normais. Esses efeitos persistiram após a ressecção do antro gástrico. Concluíram que o fator secretagogo era produzido no intestino ou no colo, durante a digestão, não era representado pela gastrina e era inativado pelo fígado. As experiências da escola de Dragstedt ${ }^{415}$, também excluíram a gastrina como fator da hipersecreção. Em bolsas gástricas totais denervadảs, em bolsas de Heidenhain denervadas e em bolsas de antro denervadas, observaram, em cãés, a persistência de hipersecreção após transposição porto-cava total (Fig. 168).

A escola de Orloff $98-558-882$ também confirmou esses resultados e obteve dados suficientes para relacioná-los com a fase intestinal da secreção gástrica. Demonstraram, em cães, que a presença de alimentos no intestino, associada à autotransfusão de sangue portal para a circulação sistêmica, causava nítida hipersecreção em bolsas de estômago sem enervação (Fig. 169). Mais tarde, esclareceram amplamente a questão. Utilizaram cães unidos aos pares por um sistema de circulação cruzada com bolsas gástricas semelhantes. Num primeiro grupo, obtiveram provas de que a circulação cruzada de per si não alterava a secreção gástrica dos dois parceiros com sistema porta normal (Fig. 170). Num segundo grupo com modelos antrectomizados e sistema porta normal, verificaram que a alimentação por jejunostomia não modificava a sua secreção gástrica nem a dos parceiros (com sistema porta normal mas não antrectomizados) (Fig. 171). Num terceiro grupo, empregaram modelos

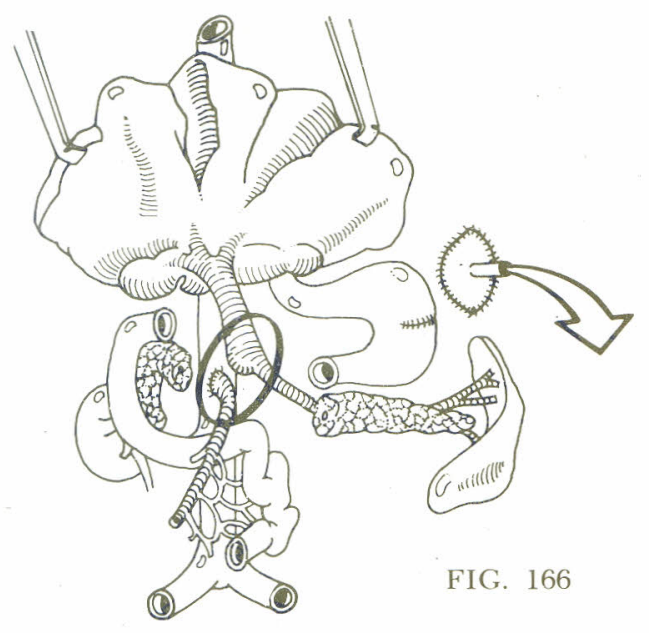

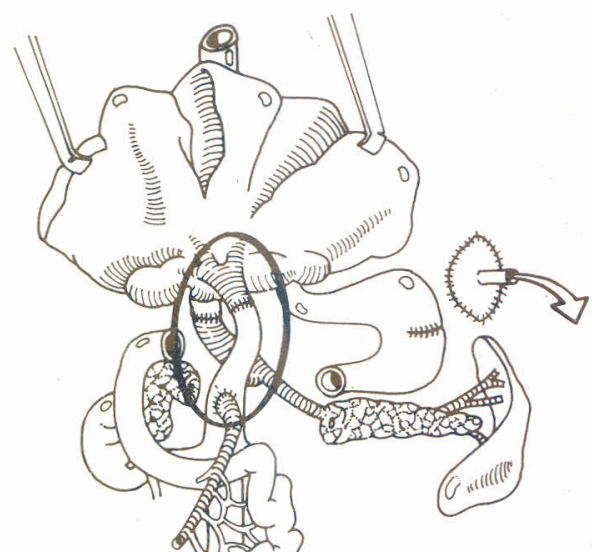

FIG. 167 

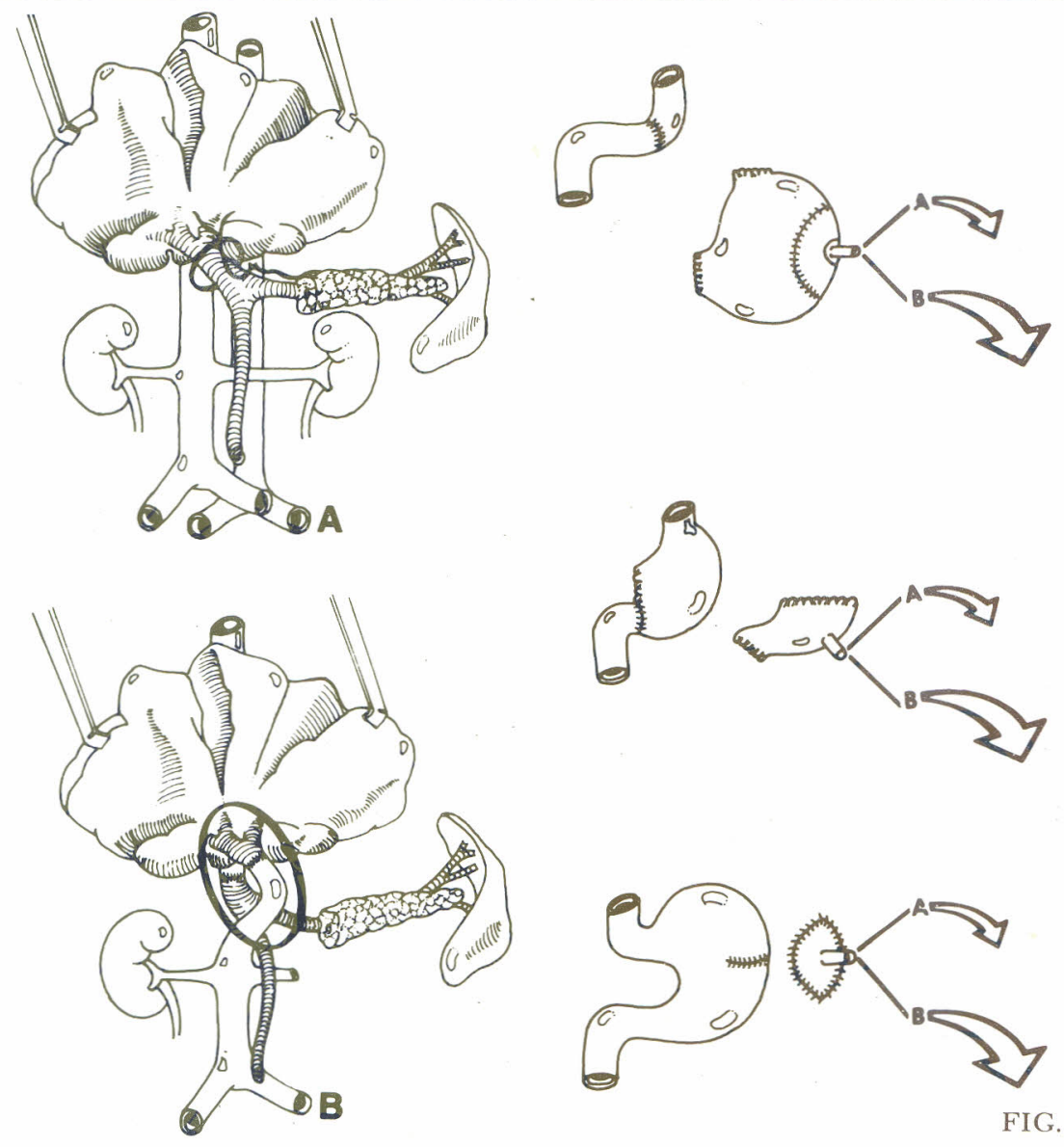

FIG. 168

semelhantes mas com FE no parceiro antrectomizado. Notaram visível aumento da secreção gástrica em ambos os componentes do par (Fig. 172). Finalmente, no quarto e último grupo, estudaram modelos idênticos aos do grupo precedente. Demonstraram que a interrupção da alimentação pela jejunostomia cessava os efeitos na secreção gástrica nos dois parceiros (Fig. 173). Baseados nesses resultados, concluíram que a hipersecreção gástrica dos animais com $\mathrm{FE}$ é conseqüente à ação de um poderoso fator secretagogo. É liberado no sangue portal durante as refeições e atinge a circulação sistêmica antes de sofrer a degradação hepática e provoca exagero da fase intes-

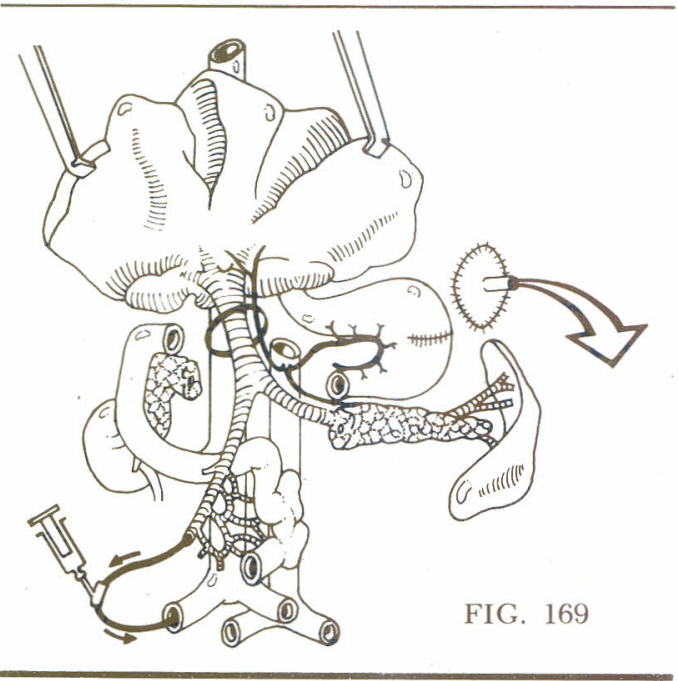




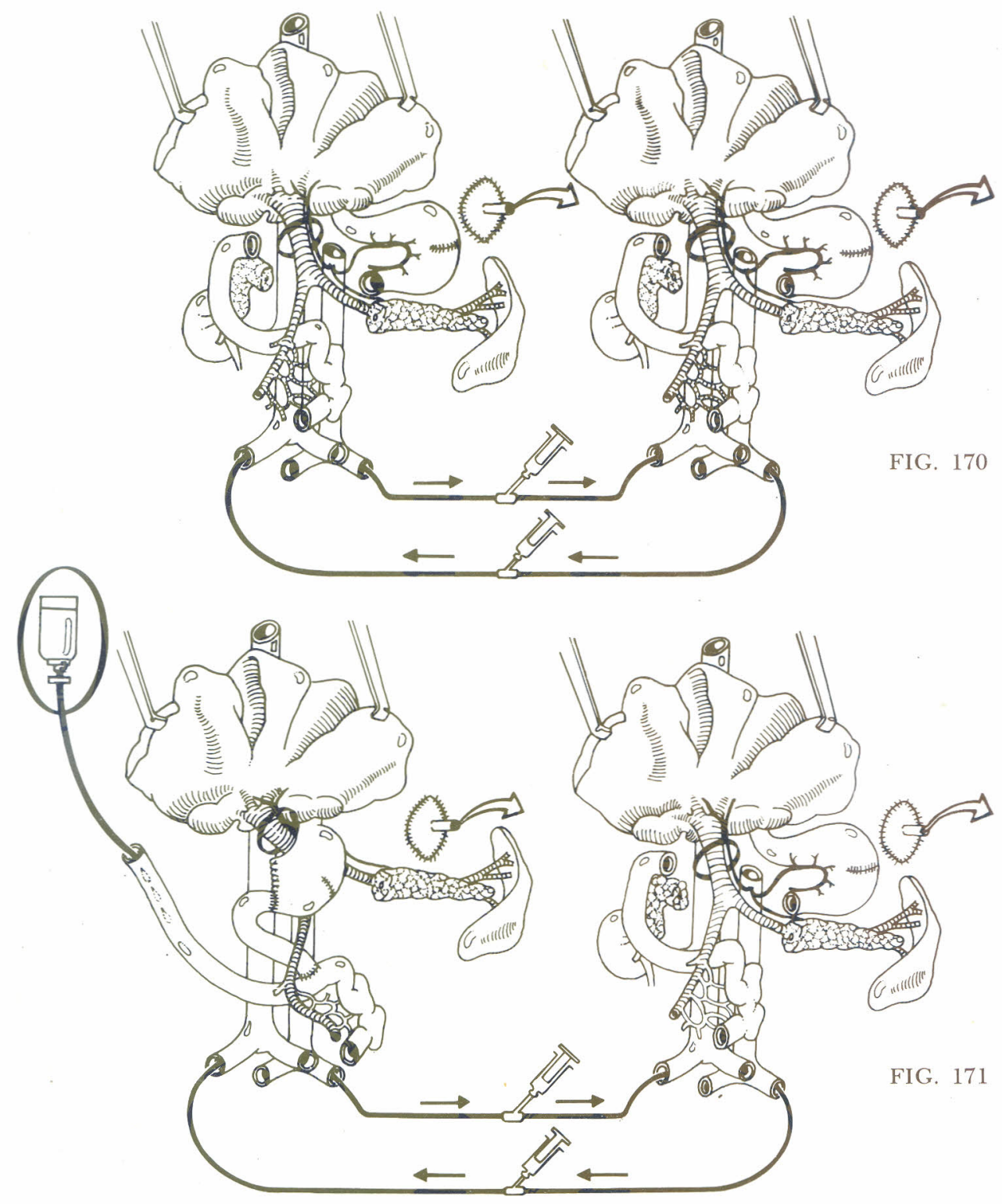

tinal da secreção gástrica. Esta interpretação foi corroborada por outros autores. Constataram que a hipersecreção persistia após a derivação do sangue venoso, proveniente do intestino delgado e grosso ${ }^{136}$ ou apenas do colo ${ }^{137}$ para a circulação sistêmica (Fig. 174). A hiperse- creção não ocorreu quando apenas o território gastroduodeno-pancreáticoesplênico foi desviado (Fig. 175) ${ }^{342}$. O efeito, porém, persistiu em modelos nos quais o sangue do colo passava pelo fígado e o sangue proveniente do intestino delgado, pâncreas e baço era desviado 

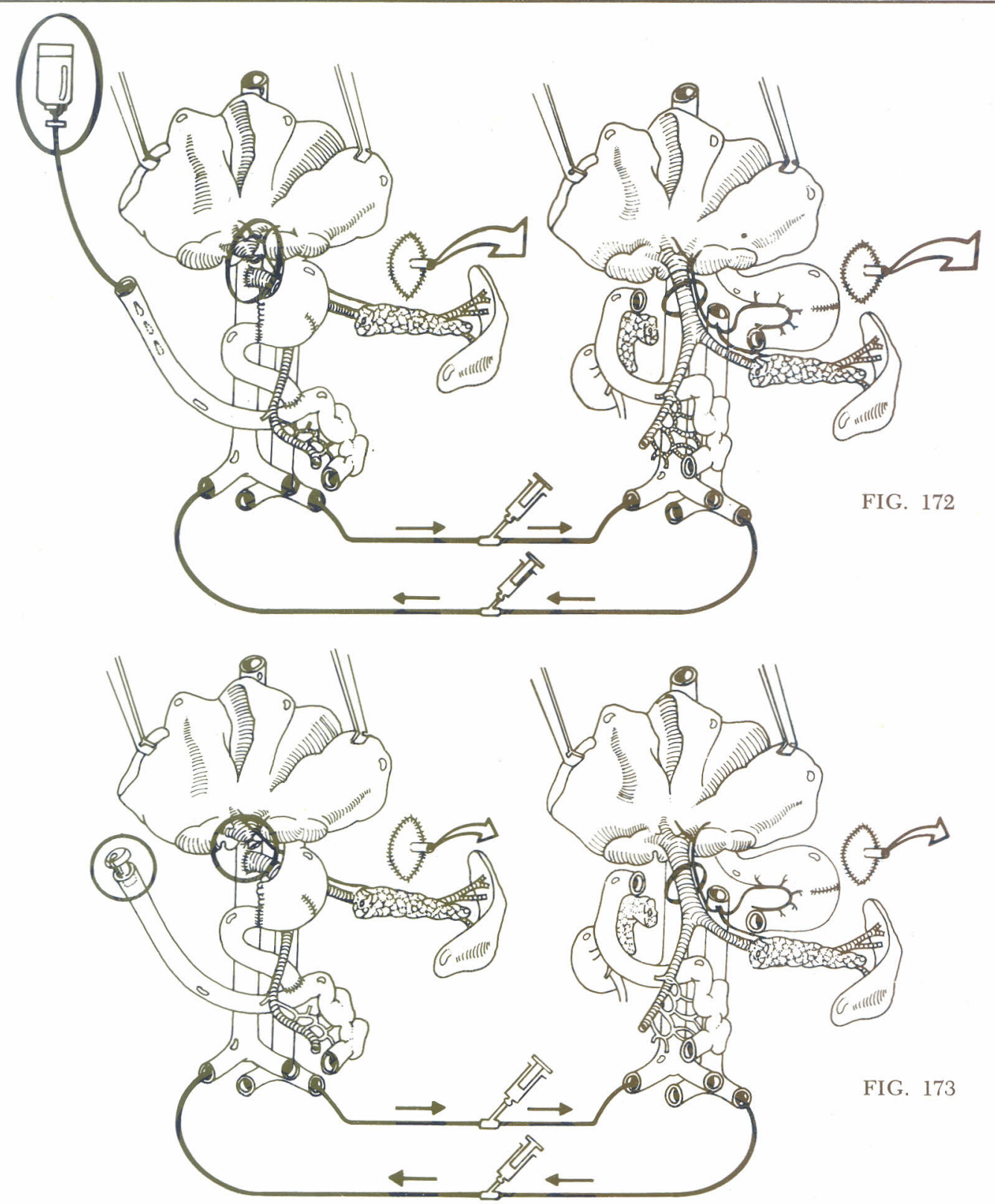

para a circulação sistêmica (Fig. 176) ${ }^{137}$. tentada por vários autores. Existe um Demonstraram, assim, que a substância em questão era produzida no intestino delgado e' grosso, e que apenas o desvio do sangue de um desses subterritórios portais era capaz de aumentar a secreçã̆o. ponto de vista geralmente aceito quanto ao seu caráter endógeno. Nega-se a possibilidade de se tratar de elemento absorvido com os alimentos. Vários autores consideram a histamina como sendo a A identificação do fator secretagogo foi responsável pelos efeitos. Outros negam 


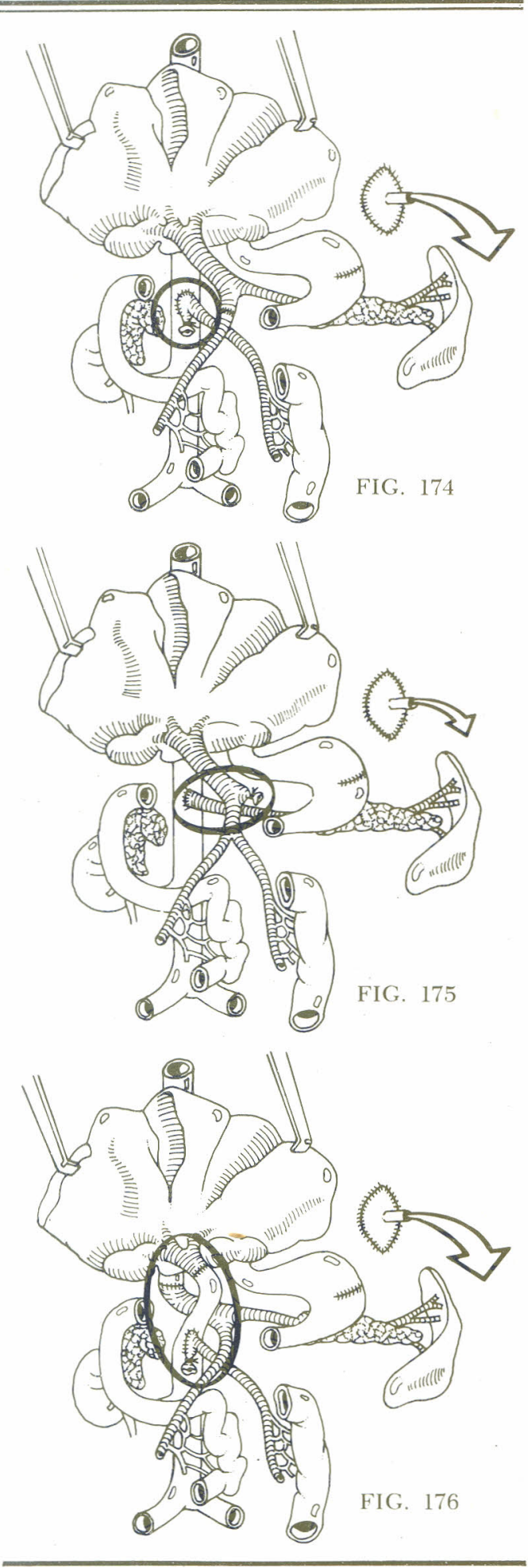

essa possibilidade. A teoria que defende a histamina tem base nas seguintes observações:

- aceita-se que a histidina, contida na carne ingerida, é descarboxilada no intestino pela flora bacteriana com formação e absorção de histamina ${ }^{372}$;

- esta última é metabolizada em parte pelo fígado. No sangue portal, é encontrada em concentrações mais elevadas que no sangue das veias supra-hepáticas e na circulação periférica ${ }^{32}$;

- a taxa de histamina no sangue arterial elevou-se em $197 \%$ após refeição de prova, em animais com transposição porto-cava total. Pelo contrário, em animais com fluxo hepático normal, a elevação foi apenas de $65 \%^{733}$;

- a infusão alternada na circulação portal (Fig. 177) ou sistêmica (Fig. 178) de soluções contendo histamina comprovou que sua passagem através do fígado diminui a resposta secretora de bolsas gástricas denervadas e reduz a excreção urinária de histamina ${ }^{638}$;

- em modelos com fluxo hepático total preservado, a quantidade de histamina absorvida em condições normais não estimulou a secreção de bolsas gástricas denervadas. Causou, porém, nítida hipersecreção em modelos com FE ou previamente tratados com antihistaminase $^{372}$.

Ao contrário, os que não admitem a teoria da histamina negam também a ação de outros fatores secretagogos no sangue portal. Atribuem a hipersecreção em animais com FE apenas a uma sensibilidade maior da mucosa gástrica aos estímulos secretagogos normais.

\section{2 \\ OBSERVAÇÕES EXPERIMENTAIS EM MODELOS COM LESÃO HEPÁTICA ASSOCIADA}

- A repetição de algumas das experiências em animais com lesão hepática associada possibilitou melhor extrapolação 

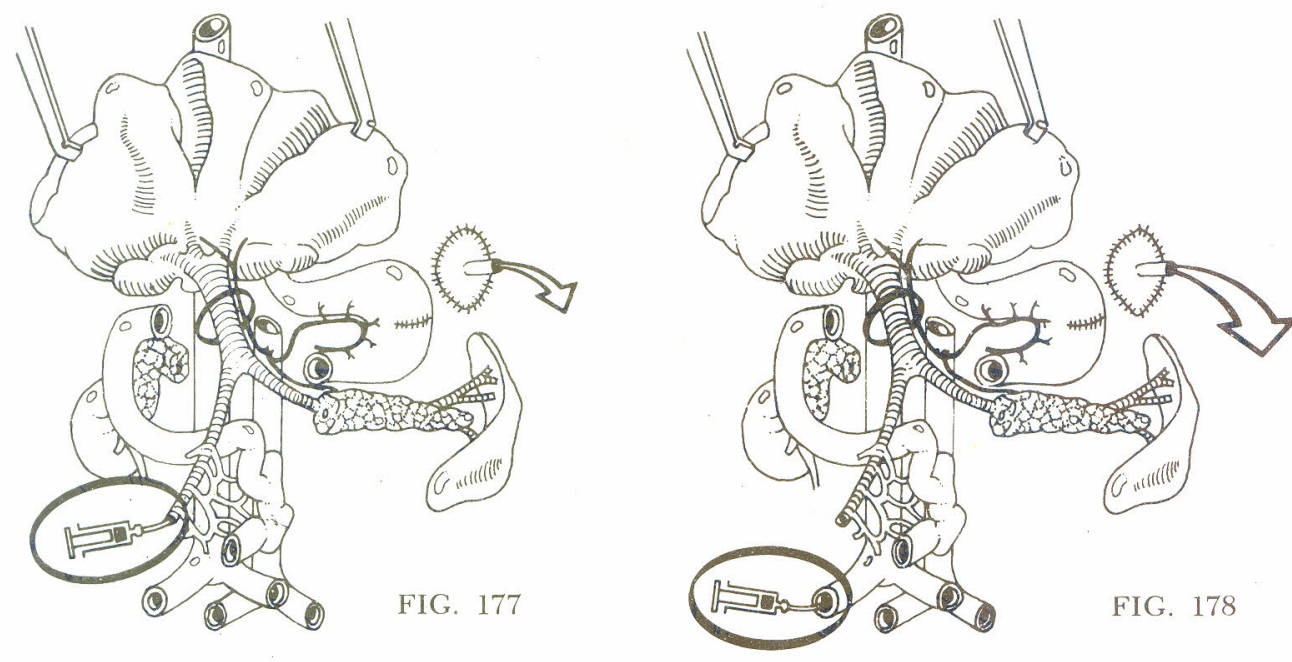

entre os modelos e as condições verificadas no homem pois a APC é quase sempre realizada em portadores de moléstias hepáticas. Contudo, a interpretação dos resultados é dificultada pela disparidade entre as informações sobre os efeitos da ação da insuficiência hepática e da hipertensão portal na secreção gástrica. A insuficiência hepática deveria, teoricamente, causar hipersecreção gástrica pela menor degradação dos fatores secretagogos intestinais. Esta previsão foi confirmada pela indução de lesão hepática aguda com tetracloreto de carbono, pela ligadura da via biliar principal ${ }^{735-747-748,}$ ou pela produção de fibrose e hipertensão portal (diminuição da reserva funcional hepática) ${ }^{344}$. Outros autores, pelo contrário, observaram diminuição da secreção gástrica em modelos com lesão hepática aguda causada por clorofórmio, éter ou tribomo-etanol ${ }^{530}$, tetracloreto de carbono ou irradiação ${ }^{781}$, ou com constrição das veias supra-hepáticas ${ }^{556}$. Ao mesmo tempo várias experiências foram efetuadas para esclarecer os efeitos da hipertensão portal em modelos com fígado normal. Em 1958, Gregory ${ }^{314}$ demonstrou que bolsas gástricas denerva- das, em nães com veia porta estenosada cirurgicamente, apresentavam hipersecreção após a administração de refeições de prova (Fig. 179). Atribuíram esse efeito ao desvio dos fatores secretagogos através da circulação colateral, apesar de observá-los já a partir de 24 horas após a constrição da veia porta. Pelo contrário, Dubuque e col. ${ }^{211}$ relacionaram efeitos semelhantes à hipertensão portal em si. Nessas circunstâncias houve nítida elevação na produção ácida de 24 horas. Orloff e col. ${ }^{556}$ estudaram cães com bolsas de Heidenhain. Mediram a secreção antes (Fig. 180) e depois de induzir cirrose, hipertensão portal e ascite pela ligadura das veias supra-hepáticas (Fig. 181). Referiram redução de $35 \%$ na produção ácida de 24 horas e redução de $72 \%$ na resposta a uma refeição de prova.

Percebe-se, dessa forma, que a interpretação dos efeitos da $\mathrm{FE}$ em modelos desse tipo é muito difícil. Não surpreendem as conclusões contraditórias a que chegaram os autores interessados no assunto. Assim, Guth ${ }^{323}$ concluiu que o desvio do sangue portal não alterava a secreção gástrica já aumentada de cães portadores de cirrose hepática induzida 

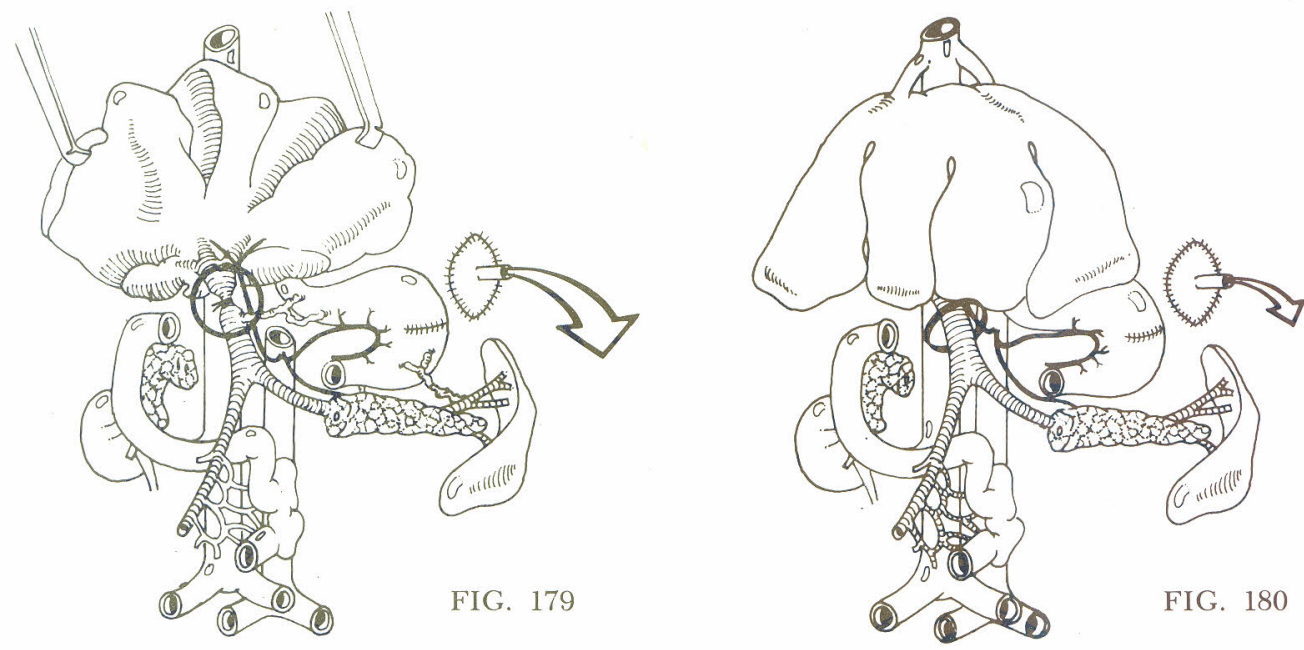

por tetracloreto de carbono. Pelo contrário, Hein e col. ${ }^{344}$ descreveram aumento adicional na secreção de 24 horas e na resposta máxima de histamina, em bolsas de Heidenhain de cães cirróticos, após transposição porto-cava total. Deduziram que o efeito era conseqüente ao desvio do sangue portal, associado à inativação ineficiente dos secretagogos pelas células hepáticas alteradas. Da mesma forma, Orloff e Windsor ${ }^{560}$ verificaram em cães com cirrose induzida pela ligadura das veias supra-hepáticas que o desvio portal provocava imediata e evidente hipersecreção em bolsas de Heidenhain (Fig. 182). Nesses animais, o aúmento na resposta ao estímulo máximo foi da ordem de $345 \%$. Desapareceu após o fechamento deliberado da FE em um animal cuja secreção retornou a níveis
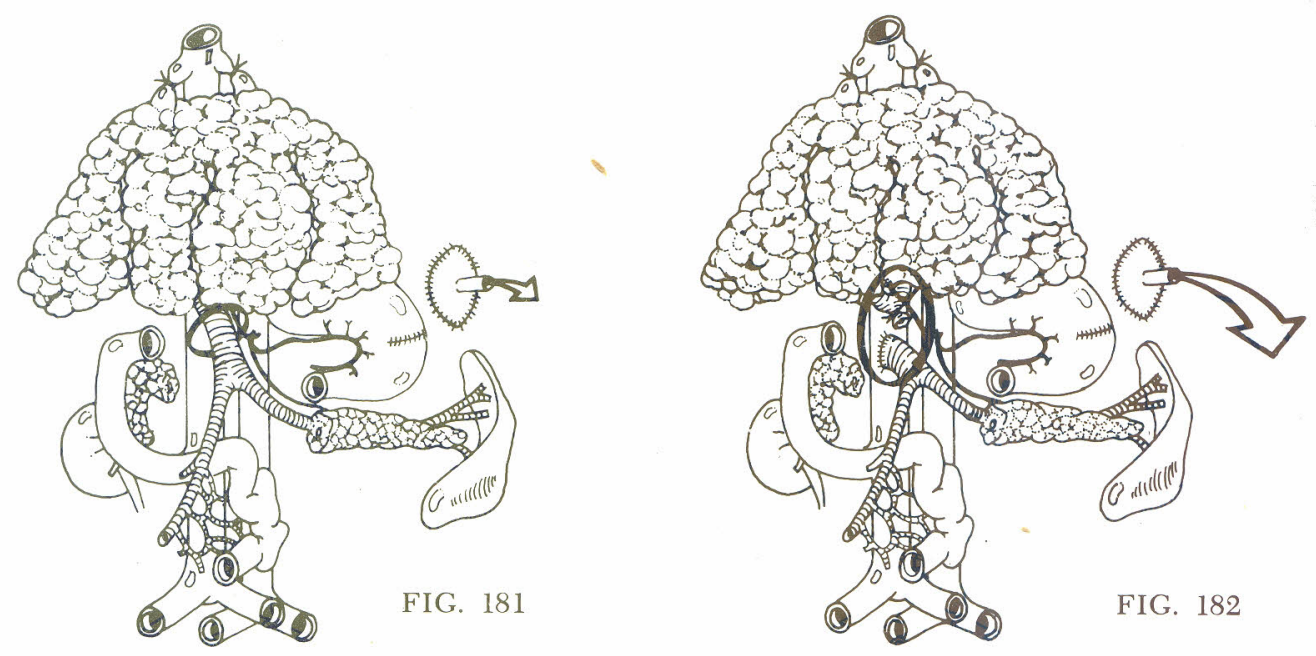
inferiores aos observados antes do desvio. Concluíram que esse comportamento mimetiza o de cães com fígado normal com FE e, provavelmente, mimetiza também o comportamento verificado em pacientes cirróticos operados.

\section{3}

OBSERVAÇÕES CLÍNICAS

Como no setor experimental, os estudos realizados para esclarecer a influência das moléstias hepáticas na secreção gástrica forneceram resultados contraditórios. Assim, Clarke e col. ${ }^{138}$ constataram pequena diferença entre a atividade secretora de indivíduos normais e cirróticos. Pelo contrário, Ostrow e col. ${ }^{562}$ e Scobie e Summerskill ${ }^{708}$ citam que pacientes com cirrose hepática compensada ou não,apresentam nítida redução da secreção gástrica. Orloff e col.557 mencionam, em cirróticos, secreção basal maior e secreção máxima igual à dos controles.

$\mathrm{O}$ estudo dos efeitos da FE na secreção gástrica de cirróticos fornece resultados diferentes conforme a metodologia. Os autores que usaram métodos não relacionados com a fase intestinal referem falta de modificação após a APC. Assim, Clarke e col. ${ }^{138}$, Bendett e col. ${ }^{54}$, Schriefers e col. ${ }^{706}$ e Wilkinson e Riddell ${ }^{878}$ não notaram diferenças significativas na secreção basal em resposta à administração de sucrose, histamina ou cafeína. Apenas Ostrow e col. ${ }^{562}$ relataram normalização da resposta à histamina, diminuída antes da derivação. Ao contrário, aqueles que estudaram a fase intestinal, como Orloff e col.557, observaram visível hipersecreção gástrica após APC, semelhante à verificada em cães com fígado normal.

No que diz respeito à incidência de úlceras pépticas em pacientes com desvio portal, nota-se, mais uma vez, falta de concordância entre as informações disponíveis. Alguns apontam maior freqüência nos operados com nítida ten- dência para lesões hemorrágicas ${ }^{376}$. Outros afirmam o contrário ${ }^{878}$. Phillips e col. ${ }^{582}$ analisaram, em conjunto, os dados publicados até 1975, relativos a cerca de 1.300 pacientes com APC. Verificaram incidência de $10,4 \%$, igual ao dobro do referido em pacientes não cirróticos. Porém, colecionando as informações disponíveis sobre 2.600 cirróticos não operados, observaram que a incidência geral foi de $10,6 \%$. Sugerem que o aumento observado em cirróticos com APC decorre da moléstia hepática e não do desvio portal. Reforçam esta conclusão examinando, em conjunto, os resultados alcançados em quatro estudos prospectivos, realizados em outros cen$\operatorname{tros}^{375-376-633-634}$ e no efetuado em seu serviço $^{582}$. Todos foram programados para avaliar a utilidade da APC como tratamento "profilático" em cirróticos. Esta análise conjunta incluiu mais de quinhentos casos divididos por escolha aleatória em dois grupos, um operado e um outro controle. Incluindo-se as lesões agudas, apenas um dos estudos ${ }^{375}$ mostrou incidência maior de úlceras pépticas nos operados. Ainda assim, os resultados foram de aceitação discutível ${ }^{582}$. No conjunto não houve diferença entre as incidências observadas nos 265 casos não operados e nos 246 submetidos a uma APC.

\section{EFEITOS EXPERIMENTAIS NO PESO CORPÓREO}

A perda de peso corpóreo destaca-se entre os efeitos sistêmicos e é variável conforme o animal estudado ${ }^{77}$. Hahn e. col., em 1893326, na análise de sessenta cães, mencionaram diminuição ponderal de $30 \%$ a $40 \%$ até a morte, ocorrida a "alguns meses depois da cirurgia". Mais tarde, em 1941, Winter e col.883, examinando o comportamento de oitenta cães, verificaram ainda maior redução, referindo desnutrição e caquexia progressivas. Geralmente um ano após a cirurgia, 
na ocasião da morte, apresentavam 1/3 do peso inicial. Na necropsia notaram visível diminuição dos depósitos de gordura. Esses resultados foram comprovados em galgos jovens por Castro e col., em 1963117, que descreveram também úlceras cutâneas de decúbito. Resultados semelhantes foram mencionados mais tarde por Jolly e col. ${ }^{390}$ e Lanier e col. ${ }^{419}$.

Em ratos, as observações são mais recentes, coincidindo com o desenvolvimento da técnica para execução de uma
FE em animais desse porte. De maneira geral, em animais adultos, cita-se menor redução de peso corpóreo do que os constatados em cães. Assim, em lotes numerosos, registraram-se, em média, reduções de 271 g para 233 g $^{252}$ e de $327 \mathrm{~g}$ para $252 \mathrm{~g}^{251}$. Estes valores foram confirmados, em linhas gerais, também por outros autores 346-669. Em animais operados antes de desenvolvimento somático, observou-se manutenção do peso corpóreo enquanto que o peso dos controles triplicou durante o período de estudo ${ }^{430}$. 